\title{
Jewish Identities in German Popular Entertainment, 1890-1930
}

\author{
BY MARLINE OTTE
}

A thesis submitted in conformity with the requirements

for the degree of Doctor of Philosophy

Graduate Department of History

University of Toronto

(c) Copyright by Marline Otte (1999) 
National Library of Canada

Acquisitions and Bibliographic Services

395 Wellington Street Ottawa ON K1A ON4 Canada
Bibliothèque nationale du Canada

Acquisitions et services bibliographiques

395 , rue Wellington Ottawa ON K1A ON4 Canada
Your file Votre reference

Our file Norre rétarence
The author has granted a nonexclusive licence allowing the National Library of Canada to reproduce, loan, distribute or sell copies of this thesis in microform, paper or electronic formats.

The author retains ownership of the copyright in this thesis. Neither the thesis nor substantial extracts from it may be printed or otherwise reproduced without the author's permission.
L'auteur a accordé une licence non exclusive permettant à la Bibliothèque nationale du Canada de reproduire, prêter, distribuer ou vendre des copies de cette thèse sous la forme de microfiche/film, de reproduction sur papier ou sur format électronique.

L'auteur conserve la propriété du droit d'auteur qui protège cette thèse. Ni la thèse ni des extraits substantiels de celle-ci ne doivent être imprimés ou autrement reproduits sans son autorisation. 


\section{Doctoral Thesis: Jewish Identities in German Popular Entertainment, 1890-1930}

\section{Marline Otte}

Department of History, University of Toronto

1999

\section{PROSPECTUS}

My thesis evaluates how the political and cultural spheres intersected in the realm of German popular entertainment. I explore the ways in which Jewish artists were able to reveal their ethnic identities in public performance, and I examine the nature and aesthetics of the various dialogues between spectators and performers. Investigating an arena that has received only marginal attention in both German and German-Jewish historiography, I focus on three distinct entertainment genres in my dissertation: the mass medium of the circus, middle-class entertainment in Yiddish theaters, and upper-class revue theaters. My thesis demonstrates that by forming new spheres of sociability and enterprise, all three aesthetic genres created grey areas of Gentile-Jewish relations, blurring the boundaries between insiders and outsiders. This ambivalence is captured and evaluated by reconstructing the everyday in Germany's booming entertainment industry. In particular, I analyze how Jewish entertainers were able to capture and inform the aspirations of mass audiences. My study demonstrates that the evolution of German popular entertainment between 1890 and the late 1920s was strongly conditioned by Jewish entertainers and entrepreneurs. Drawing upon recent debates in German history, Cultural Studies and German-Jewish history, my study reevaluates the way contemporary Germans -- Gentiles and Jews -- thought about ethnic and cultural diversity in a time of rising nationalism. 


\section{Contents}

Popular Entertainment: A new Public Sphere

I "Ponim et Circenses": Jewish Identities in Circus Entertainment, 1870-1928

Chapter 1 The Circus in Time and Space $\quad 32$

Chapter 2 Circus Life $\quad 59$

$\begin{array}{ll}\text { Chapter } 3 \text { Artists and Audiences } & 80\end{array}$

Chapter 4 "Puppchen, Du bis mein Augenstern!"

-- Aesthetics and the Challenges of War 91

II Comic Relief: Jewish Identities in Jargon Theater from 1890 to the 1920 s

$\begin{array}{ll}\text { Chapter } 5 \text { Jargon as Art } & 119\end{array}$

Chapter 6 Life in Jargon Theater 133

$\begin{array}{ll}\text { Chapter } 7 \text { Artists and Audiences } & 148\end{array}$

$\begin{array}{ll}\text { Chapter } 8 \text { Aesthetics } & 179\end{array}$

III Jewish Identities in Revue Theater, 1898-1933

Chapter 9 Entertaining Berlin's new Elites: The Metropol Theater 209

Chapter 10 Metropolitan Life $\quad 220$

Chapter 11 The Metropol and its Critics $\quad 244$

$\begin{array}{ll}\text { Chapter } 12 \text { Aesthetics } & 253\end{array}$

$\begin{array}{ll}\text { Conclusion } & 283\end{array}$

$\begin{array}{lr}\text { Appendix } & 289\end{array}$

$\begin{array}{ll}\text { Bibliography } & 307\end{array}$ 


\section{Popular Entertainment: A new Public Sphere}

Questions about German-Jewish identity and the integration of Jews into German society have not diminished in importance since Nazi Germany's near-destruction of European Jewry during the Second World War. Historians of German-Jewish history have frequently considered the decades prior to 1933 as a mere prelude to the Holocaust -- even, indeed, as a period of moral decay and social disintegration. Many historians have equated assimilation with false consciousness, leading to self-denial among Germany's Jews. Yet an analysis of three central genres of live entertainment -- the circus, the Jargon theater, and the revue theater -demonstrates that Jewish entertainers and entrepreneurs shaped the evolution of German popular entertainment between 1890 and the late 1920s. Jewish entertainers formed an integral aspect of the history of popular live entertainment in Germany prior to $1933 .{ }^{1}$ German-Jewish stage performers, theater directors, and producers shaped and reflected the dreams and aspirations of the masses who seemed to find pleasure and satisfaction in the exhilarating amusements of the countless new forms of live entertainment in these decades. As popular entertainment created new spheres of sociability and enterprise, it also created gray areas of Gentile-Jewish relations, blurring and redrawing the boundaries between insiders and outsiders. This study attempts to capture and explore this ambivalence. By analyzing the aesthetics and social relations of entertainers, one can gain insight into the complex relationships between Gentiles and Jews in the realm of culture as well as within German society at large. Looking through the prism of German popular culture in the late nineteenth and early twentieth centuries allows us to develop a new understanding of German-Jewish identities.

1 Peter Gay has made a similar argument for the relationship between the history of Germany's Jews and German history at large. Peter Gay, Freud, Juden und andere Deutsche (Munich, 1989), 11. 
By the turn of the century, the boundaries of culture traditionally associated in Germany with the bourgeois ideal of Bildung (self-formation) began to be openly challenged. An expanding urban popular culture, as reflected in films, tabloids and sport events, fundamentally altered the social realities of many Germans. Traditional expressions of art began to appear increasingly stale, elitist, and uninspiring. Film, radio and television were not, however, the first mass media to leave their mark on the collective consciousness of the German population.2 Antecedents, such as the circus fulfilled much of this function around the turn of the century. The circus drew millions of spectators annually, to whom it disseminated, verbally and nonverbally, information and entertainment. ${ }^{3}$ To a significant degree the circus influenced its spectators' notions of foreign worlds, as well as ideas about the relationship between nature and man. In the realm of circus entertainment, as elsewhere, "the medium was the message." ${ }^{n}$ As with film and radio, the circus employed its own technological apparatus to convey such messages. Circuses, Jargon theaters, and revue theaters formed part of an entertainment industry that catered to the growing urban population of Imperial and Weimar Germany. Their primacy remained unchallenged until the arrival of cinema. ${ }^{5}$

2 Pierre Sorlin, Mass Media. Key Ideas (London, 1994). Although an excellent introduction to the vast literature on "mass culture," it is quite representative of that literature in its neglect of popular entertainment forms prior to film.

3 The average circus seated between 2,500 to 5,000 spectators in one show. Each circus performed at least twice a day. Even the traveling circuses performed at least six months. If we assume that a traveling circus could only perform 120 days a year, it reached approximately 600,000 spectators during that time. A stationary circus, which performed all year round reached in average more than two million spectators a year.

4 Marshall Mc Luhan, Understanding Media (New York, 1964), $32 \mathrm{ff.}$

5 Bim Mason, Street Theatre and other Outdoor Performance (London, 1992), 17. An excellent introduction to the history of European circuses is also provided by Jewgeni Kusneszow, Der Zirkus der Welt (Berlin, 1970); on German circuses see also Dietmar Winkler, Zirkusgeschichte (Berlin, 1986); Robert A. Jones, Art and Entertainment: German Literature and the Circus, 1890-1933 (Heidelberg, 1985); Joseph Halperson, Das Buch vom Zirkus, Beiträge zur Geschichte der Wanderkünstlerwelt (Düsseldorf, 1926); Günter 
Live entertainment was an important element in the everyday life of many Germans. As leisure time increased more and more Germans sought distraction in theaters, circuses, at sports events, and trade fairs. Well-informed group of critics discussed the premieres of live productions on the front pages of daily newspapers. A high profile in the daily press was crucial to attract a mass audience; Berliners, especially, relied heavily on the daily press to map out the imaginative landscape of their urban environment. ${ }^{6}$ This fascination with popular live entertainment was not confined to Berliners alone. On the contrary, every medium-sized city took pride in its circuses and theaters. City dwellers were well acquainted with the local stars, their private lives, and their public scandals. Provincial towns swelled with enthusiasm and pride at the occasional guest performance of a prominent entertainer from Berlin. To succeed in local politics it was indispensable to be seen at these events, and local elites made sure they were acquainted with the latest shows and tunes and sought the friendship of upcoming entertainment stars. Although Berlin acted as the capital of live entertainment, most of the city's larger theaters and circuses believed success was depended on their shows being discussed throughout the country.

An exploration of the realm of circuses, Jargon-, and revue theaters must consider the representation of Jewish identities in German popular media, as well as their reception by Gentile and Jewish audiences. We have to ask when and why individual artists invoked their ethnic identity over other possible identities such as age, gender, or class. How did Jewish performers use visual and verbal language to express their urge for belonging, their sense of self? Here too, their history and tradition must be included in the analysis. This approach

Bose and Erich Brinkmann, Circus. Geschichte und Ästhetik einer niederen Kunst (Berlin, 1978); Wolgand Carlé, Das hat Berlin schon mal gesehn. Eine Historie des FriedrichstadtPalastes (Berlin, 1982); G.B. Eberstaller and Paul Christian, Circus (Vienna, 1976); J. Merdert ed., Zirkus, Circus, Cirque. 28. Berliner Festwoche, Nationalgalerie Berlin, 1978; a quite different approach to circus art is taken by Paul Bouissac, Circus and Culture. A Semiotic Approach (Bloomington, 1976).

6 Peter Fritzsche, Reading Berlin 1900 (Cambridge, MA, 1996). 
allows historians to move beyond an analysis of cultural organizations alone to gain deeper insights into the fluid processes of identity formation and self-representation. This study illustrates the way entertainment in a particular time and place defined and expanded the boundaries of what is socially and culturally tolerated. It does so by evaluating how the stage or the ring functioned as a space that served to alter the public's view of "the other."

\section{Popular Culture and Jewish Identity}

Popular entertainment is a particularly rich field for the study of ethnic identity. Its analysis provides important insights into German society at large, because it encouraged extensive interaction between performers and audiences. ${ }^{7}$ Long before postmodernism provoked a heated debate among intellectuals about the "location of culture," about who could or should claim responsibility for the production of meaning, German performers in circuses, variety shows, cabarets, and music theaters understood that the success of their aesthetic enterprise lay in the audience's reception. ${ }^{8}$ Most new forms of popular entertainment fostered a greater intimacy between audiences and performers. Many acts were choreographed as a ritualized dialogue, leaving ample opportunity for direct interaction with the audience.

7 For the concept of "ethnicity" and Jewish identity see Shulamit Volkov, "Die Erfindung einer Tradition. Zur Entstehung des modernen Judentums in Deutschland," in Historische Zeitschrift 253 (1991): 603-28; Marion Berghahn, German-Jewish Refugees in England (London, 1984); Till van Rahden, "Weder Milieu noch Konfession. Die situative Ethnizität der deutschen Juden im Kaiserreich in vergleichender Perspektive," in Olaf Blaschke and Frank-Michael Kuhlemann, eds., Religion und Milieu im deutschen Kaiserreich (Gütersloh, 1996).

8 Reference to a concept employed by Homi Bhabha, The Location of Culture (London, 1994). On the importance of the interactive nature of modern popular theater, see Erika Fischer-Lichte, Die Entdeckung des Zuschauers. Paradigmenwechsel auf dem Theater des 20. Jahrhunderts (Tübingen, 1997); idem, The Show and the Gaze of the Theatre. A European Perspective (Iowa City, 1997). 
Those new forms of entertainment transcended not only the traditional division between audience and performer, but also the division between author and performer. As more and more performers created their own acts, entertainment became a function of the performer's courage, creativity, and training. ${ }^{9}$ Popular entertainment left the performers ample opportunity for individual expression in regard to style and content. The increasing importance of performers disclosed their specific message as well as their public persona. Because they wrote, choreographed, performed, and often managed their own work, German-Jewish performers avoided the constraints of traditional stage roles. ${ }^{10}$ Although not completely free in their choice of costume, humor, style, and content, they entered an "arena of negotiation" with their audience, the stage owner, municipal governments, the press, and the state. Traditional theater performances, by contrast, worked with a clearly defined script that could not be altered by the actors. In these performances it was much harder to determine the individual motivation of the performers, their personal background, and their cultural baggage. Popular entertainers both transformed, and were transformed by, the act of transgressing social and cultural boundaries. This study explores these negotiations between German-Jewish performers and their audiences, interpreting their successes and their failures.

In the arena of popular entertainment, norms and rules applying to society at large were often suspended or inverted. Popular live entertainment in the early twentieth century was a marketplace of meaning in which a fine balance between the exotic and the familiar was crucial for success. However, its apparent commercialization hindered its inclusion into the framework of legitimate "high" culture. Conceiving of art "as a touchstone of the highest values of civilization," most contemporary critics denied popular entertainment a place in the classical

9 On the importance of the interaction between actor and audience, see Bim Mason, Street Theatre and other Outdoor Performance (London, 1992), 11.

10 This was a remarkable freedom, especially when compared with the limited choices Jews had faced on the stage in the previous centuries. For an insightful discussion of Jews in the 
cultural canon because, in order to succeed, it was compelled to appeal to the greatest common denominator. "Contemporaries' specific definition of culture was based on distinction, and was informed by their specific notions of civilization, nature, and the hegemony of public taste. ${ }^{12}$ Putting these contemporary judgments at arm's length, this study proceeds from the assumption that culture is "ordinary," or "everyday," reconstituting itself through a process of creation and redefinition of meaning. As will be demonstrated, the circus, Jargon-, and revue theater, distinguished by their wide-ranging repertoire and socially diverse audiences, often eluded classification within the structure of mass- and elite culture. Instead, they functioned as experimental stages for artistic innovation, mediating between the different artistic worlds of popular and "legitimate" culture.

\section{State of the Art}

To date, scholars of American history have been more inclined than Germanists to break with the parameters of traditional cultural history and to integrate questions of identity into their research. Although there have been attempts, especially among Americans studying German history, to integrate ethnic or minority studies, as well as studies in mass culture and communications into the German debate -- not least because these also seemed meaningful outside of the academic setting -- a conceptional "divide" continues to separate the fields of German and North American history. Many ideas put forth by scholars involved in American cultural history as well as in American ethnic studies have only recently made inroads into

traditional theater scene, see Hans-Joachim Neugebauer, Judenfiguren. Drama und Theater im frühen 19. Jahrhundert (Berlin, 1994).

"Among many see Ludwig Seelig, Geschäftstheater oder Kulturtheater? (Berlin, 1914).

12 Stuart Hall, "Cultural Studies: Two Paradigms," in Nicholas B. Dirks, Geoff Eley, and Sherry B. Ortner, eds., Culture/Power/History (Princeton, 1994), 522. Hall is making reference to a concept Raymond Williams put forth in one of his earlier attempts to define culture. Raymond Williams, The Country and the City (London, 1973). 
German discussions, a phenomenon which Michael Geyer and Konrad Jarausch have described as the "belatedness" of German historiography. ${ }^{13}$

With few exceptions, neither German- nor English-speaking historians of Germany have appreciated the potential of performances for historical interpretation. ${ }^{44}$ Recent conceptual revisions of the notions of "mainstream," "homogeneity," and "center and periphery" have resonated in the treatment of popular cinema by American historians and film specialists; but they have failed to leave a lasting imprint on work dealing with German society. With their increasing interest in the complicated and manifold processes of identity formation, American historians breathed new life into the study of art, by being less concerned with styles of representation or performance than with agency, reception, and representation. ${ }^{i s}$ Fueled by an interest in multiculturalism, new attention has been directed to ethnic, racial, and sexual diversity, ambiguity and difference in the past decade. This shift of interest largely resulted from the feminist and civil rights movements in America. In addition, the challenges of new media technologies led to a renewed interest in the relation between image and information and generated a debate about the role and importance of aesthetics in society.

Although questions of Jewish identity are an established topic within the study of minorities among Americanists, they have not figured prominently in cultural studies until the past decade. Since the mid-1980s, important studies have changed the way we understand the role and importance of ethnic identity in mass culture today. Studies by Neal Gabler, J. Hoberman and Michael Rogin have discussed the American Jewish experience through an

13 Michael Geyer and Konrad H. Jarausch, "Great Men and Postmodern Ruptures: Overcoming the "Belatedness" of German Historiography," German Studies Review 18 (1995), 253-273.

is Peter Jelavich, Berlin Cabaret (Cambridge, MA, 1993).

is See among many, Miriam Hansen, Babel \& Babylon. Spectatorship in American Silent Film (Cambridge, MA, 1994). 
examination of the film industry and its function in society at large. ${ }^{16}$ Central to all these studies was the question of whether it was possible to gain admission into the mainstream without shedding one's own ethnic or cultural specificity, without losing one's culturally distinctive voice. Gabler points to the ways in which immigrant Jewish entrepreneurs sought to demonstrate their Americanness and in so doing made fundamental contributions to its actual formation. Rogin argues that it was "the blackface masquerade that paradoxically made it possible for immigrant Europeans -- first the Irish and then the Jews -- to pass [into the mainstream]." ${ }^{17}$ Hoberman points to the function of Yiddish filmmaking in the preservation and more importantly the re-creation of a distinctly Jewish culture: "This new Yiddish culture was at home neither with the Jewish past nor with the Gentile present. As Yiddish artists and intellectuals embraced secular ideologies and opened themselves to their surroundings, they risked the loss of a tribal identity; similarly, because the movies were a public sphere, even the creation of a specific Jewish cinema jeopardized Jewish insularity." 18 It is clear that Jews conceived of the realm of entertainment as a sphere that was especially rewarding, both in economic and in emotional terms. The new film industry was not characterized by the same

16 Michael Rogin, White Noise: Jewish Immigrants in the Hollywood Melting Pot (Berkeley, 1996); Neal Gabler, An Empire of their own. How the Jews invented Hollywood (New York, 1988); J. Hoberman, Bridge of Light. Yiddish Film between two World Wars (Philadelphia, 1991); S.B. Cohen, ed., From Hester Street to Hollywood. The JewishAmerican Stage and Screen (Bloomington, 1983).

17 J. Hoberman, "My song means as much to my audience as yours to your congregation," in London Review of Books, 18 July 1996, 22.

18 Hoberman concludes that both the medium and the preservationist impulse were modern. Thus, whereas the intention was oriented towards history and tradition, the product was something entirely new. J. Hoberman, Bridge of Light. Yiddish Film between two World Wars (New York, 1991), 8. 
prejudices against Jews that existed in other fields of endeavor. ${ }^{19}$ Through film, this formerly marginalized and persecuted minority emerged as a highly visible and empowered group.

Much can be gained from applying the conceptual framework of these studies to German cultural studies. As in America, at the turn of the century many German entertainers were of Jewish origin. But unlike Americanists, Germanists have paid little attention to the important role of Jews in German popular culture. ${ }^{20}$ To this day, we lack a serious study of why German Jews chose to engage in the realm of popular entertainment to such a great extent, and how their ethnic identity shaped their professional and private lives. In light of the vibrant cultural life of Wilhelmine and Weimar Germany, it remains unclear why the notable presence of Jews in German mass entertainment has not stimulated greater scholarly interest. Three sets of reasons come to mind, each of which fundamentally distinguishes the German from the American situation:

1. Traditionally, German historiography, insofar as it dealt with the relationship between "culture" and "society" at all, has borne two distinctive features. Since the 1970s German historical thinking has been heavily shaped by a Marxist-influenced tradition, one relevant even for non-Marxists. This reliance led to an emphasis on the relation between culture and class. Other forms of differentiation such as gender or ethnicity did not receive as much consideration. Religion remained the only other category to attract scholarly attention." In

19 Hans Feld, "Jews in the Development of the German Film Industry. Notes from the Recollections of a Berlin Film Critic," in Leo Baeck Institute Year Book XXVII (1982), 337.

Hans Feld being a notable exception to the rule.

Wolfgang Schieder, ed., Volksreligiosität in der modernen Sozialgeschichte (Göttingen, 1986); idem., Religion und Gesellschaft im 19. Jahrhundert (Stuttgart, 1994); David Blackbourn, Marpingen: Apparitions of the Virgin Mary in Bismakian Germany (Oxford, 1993); Margaret Lavinia Anderson, "Piety and Politics: Recent Work on German Catholicism," Journal of Modern History 63 (1991), pp. 681-716; Helmut Walser Smith, German Nationalism and Religious Conflict: Culture, Ideology, Politics, 1870-1914 
recent years, the primacy of class in determining social distinctions has been contested by gender historians on both continents. Ann Taylor Allen has suggested that the deficiency in German historiography in the 1960s and 1970s was a result of the absence of political movements in Germany such as the Black Power movement in the United States, which could have offered theoretical alternatives to the Marxist paradigm. ${ }^{22}$ This lack of alternative theoretical concepts was even more pronounced when it came to ethnicity as a category of historical analysis. Unlike gender, ethnicity has not yet found its advocate in German historiography.

2. There has been a strong tendency among German historians to assume that sociological factors determined the reception as well as the production of cultural symbols in German society. Thus, organizations involved in the production of cultural objects have received scholarly attention, whereas "unorganized" cultural production outside the realm of associational life remain on the periphery of historical analysis. Among historians of modern Germany, labor historians were the first to conduct serious historical research on popular culture and mass media. These historians came to view cultural expressions in terms of social conflicts between classes, or as conflict between civil society and the state. Social conflicts seemed to be studied best by focusing on cultural organizations and the activities of the workers movement. ${ }^{23}$ With the notable exception of the works of Lynn Abrams, amusements

(Princeton, 1995); Olaf Blaschke and Frank-Michael Kuhlemann, eds., Religion und Milieu im deutschen Kaiserreich (Gütersloh, 1996).

22 Ann Taylor Allen, "Women's Studies as Cultural Movement and Academic Discipline in the United States and West Germany: The Early Prase, 1966-1982," in Women in German Yearbook 9 (1993), 5.

23 Although Jürgen Kocka has pointed to the fluid nature of workers culture during the nineteenth century, historical research has largely focused on organizational histories. Jürgen Kocka, ed., Arbeiterkultur im 19. Jahrhundert, Geschichte und Gesellschaft 5, no.1, (1979). For the persistence of the "organizational approach" see Gerhard A. Ritter and Klaus Tenfelde, Arbeiter im Deutschen Kaiserreich 1871-1914 (Bonn, 1992), especially chapter IX: "Das Milieu der Arbeiter"; Gerhard Ritter, ed., Arbeiterkultur 
such as the circus or the variety show often remain neglected by labor historians, because the audiences of these forms of amusement defied clear-cut definitions of class and political orientation. ${ }^{24}$

Scholars concerned with Germany's Bürgertum (middle classes) have demonstrated an even greater reluctance than labor historians to consider popular entertainment as a "serious" arena of public discourse. Although historians today agree that leisure-time activities played a major role in the constitution of a public sphere, most research has focused on bourgeois associational life (Vereinswesen). ${ }^{25}$ Often relying heavily on Jürgen Habermas's concept of the public sphere, they analyze how the dramatic increase in voluntary associations created a public sphere that was reserved for male citizens. They draw attention to the crucial role of such associations in the creation of a rational discourse and a middle-class consciousness, both of

(Königstein, 1979); Vernon L. Lidtke, The Alternative Culture. Socialist Labor in Imperial Germany (New York, 1986); Dieter Langewiesche, "Working-Class Culture and WorkingClass Politics in the Weimar Republic," in Roger Fletcher, ed., Bernstein to Brandt (London, 1987).

24 Lynn Abrams was one of the first to break out of the constraints of the organizational life of workers' culture. Lynn Abrams, Workers' Culture in Imperial Germany. Leisure and Recreation in the Rhineland and Westphalia (London, 1992). See also idem, "Zur Entwicklung einer kommerziellen Arbeiterkultur im Ruhrgebiet," in Dagmar Kift, ed., Kirmes-Kneipen-Kino. Arbeiterkultur im Ruhrgebiet zwischen Kommerz und Kontrolle (1850-1914) (Paderborn, 1992), 33-59. For a highly informative synopsis of major trends and developments in the field of Cultural Studies, see Stuart Hall, "Cultural Studies: Two Paradigms," in Dirks, Eley, and Ortners, eds. Culture, 520-538.

${ }_{25}$ The most prominent works on the German bourgeoisie stress the importance of the bourgeois assiciational life for the formation of a bourgeois Selbstverständnis, see Jürgen Kocka, ed., Bürgertum im 19. Jahrhundert vols. \#1-3 (Göttingen, 1995); David Blackbourn and Richard J. Evans, eds., The German Bourgeoisie. Essays on the social history of the German middle class from the late eighteenth to the early twentieth century (London, 1991); see also Thomas Nipperdey, "Verein als Soziale Struktur in Deutschland im späten 18. und frühen 19. Jahrhundert," in idem, Gesellschaft, Kultur, Theorie. Gesammelte Aufsätze zur neueren Geschichte (Göttingen, 1976), pp. 174-205. 
which in turn underpinned middle-class claims to provide social and political leadership. ${ }^{26}$ But Germany's urban culture after 1890 included many new public spaces, including in particular those sites of popular amusement that were accessible to women and men, working and middle classes, insiders and outsiders of society. It is these sites that remain so conspicuously undervalued by historians who focus on the "ideal-type" public sphere exclusively. To be sure, a highly developed associational life continued to serve as a forum for public debate and social networking. Nevertheless, popular entertainment contributed to a redefined public sphere in the first decade of the twentieth century. ${ }^{27}$ In fact, many middle-class associations came to be part of this new sphere as regular "collective" consumers of popular entertainment. Lynn Abrams has argued persuasively that "it was the urban bourgeoisie who, while decrying the drinking and dancing of the lower classes, began to take their own recreation into the public arena: they visited theaters, played sport, strolled in parks and zoological gardens and commandeered trains to take them out of the cities. ${ }^{28}$ By literally challenging the boundaries of the bourgeois home, a division essential to Habermas's concept, these activities blurred the boundaries between the private and public spheres. Live entertainment was an essential part of these "decentered publics." Anything but apolitical, it reflected and shaped many Germans' views of local and national politics and the interpretation of national and international events. ${ }^{29}$ Hence

26 Harry C. Boyte, "The Pragmatic Ends of Popular Politics," in Craig Calhoun, ed., Habermas and the Public Sphere (Cambridge, MA., 1992), 342-43.

27 See Ursula Frey, "Vom Kulturverein zur Vereinskultur. Organisierte Geselligkeit als populäre Freizeitgestaltung nach 1850," in Dagmar Kift, ed., Kirmes-Kneipe-Kino, pp. 169-195; Konrad Dussel and Mathias Frese, "Von traditioneller Vereinskultur zu moderner Massenkultur? Vereins- und Freizeitangebote in einer südwestdeutschen Kleinstadt 19201960," in Archiv für Sozialgeschichte 33 (1993), 59-105.

Lynn Abrams, "From Control to Commercialization: the Triumph of Mass Entertainment in Germany 1900-25?" in German History 8, (1990), no. 3, 278. See also Asa Briggs, Mass Entertainment: The Origins of a Modern Industry (Adelaide, 1960).

29 For example, it was not only the press that informed Europeans of the seemingly unlimited opportunities to riches during the years of the goldrush in the American West. Circuses all 
this dissertation can be seen as contributing to the ongoing debate that was recently identified by Mary Ryan, Geoff Eley and Harry C. Boyte when they called for more research on the diversity of German publics and their changing contours. ${ }^{30}$

The tendency of German historians to focus on organizations and structures was heightened by their attempt to explain the rise of German antisemitism and the failure of Jewish emancipation in Germany in light of the Holocaust. Throughout the 1970s and 1980s, historians searched for the causes of the "German catastrophe" in the economic or political spheres of German society, concentrating on those areas in which antisemitism found a direct and institutionalized expression. ${ }^{31}$ Artistic as well as social expressions of ambivalence inherent to the realm of mass culture found even less attention among those scholars of modern German history in search of clarity and culprits. German Jews were examined as the victims of persecution and exclusion, and as such were treated as objects. Deprived of their agency, their cultural participation and creativity received only marginal recognition in German-Jewish historiography. Historians therefore continued to polarize German society into a majority and a minority culture, periphery and center, constructing monolithic and mutually exclusive identities. They seem to have been unaware that the very distinction between a minority and a majority perpetuated the marginalization of the German Jewish community.

over Europe mounted spectacular shows focusing on the Klondike experience for those who dared to leave the familiar.

30 See their contribution to Calhoun, ed., Habermas and the Public Sphere.

31 Norbert Kampe, Studententum und 'Judenfrage' im Kaiserreich (Göttingen, 1988); Shulamit Volkov, Jüdisches Leben und Antisemitismus im 19. und 20. Jahrhundert (Munich, 1990); Peter Pulzer, The Rise of Political Anti-Semitism in Germany and Austria, rev. ed. (Cambridge, MA, 1988); Peter Pulzer, Jews and the German State (London, 1992); Reinhard Rürup, Emanzipation und Antisemitismus, Studien zur "Judenfrage" der bürgerlichen Gesellschaft (Frankfurt a. M., 1975); Helmut Berding, Moderner Antisemitismus in Deutschland (Frankfurt a. M., 1988), Jacob Katz, Vom Vorurteil zur Vernichtung (Munich, 1989). 
3. Both historians of German culture and of German-Jewish relations have been reluctant to consider primarily visual, often nonverbal, art as a source for historical analysis. For German cultural historians, visual entertainment, unlike painting, has not been considered to be part of the legitimate cultural canon. Despite the long tradition of the interpretation of imagery by medievalists, ethnographers, and art historians, historical writing on modern Germany has relied mainly on written sources. Visual mass culture has been viewed as supposedly mindless and debased, even though the growing emphasis on visual communication is a distinctive feature of modern life. It has been assumed that popular culture was a mere imitation of high culture, a cheap, commercialized copy of an esteemed original, inarticulate and hardly worth considering. ${ }^{32}$

Most studies of bourgeois culture in the "long nineteenth century" center on high culture such as parlor music, the opera, or theater. All of these art forms relied heavily on the verbal dimension of their performance. ${ }^{33}$ Studies in low culture, such as the circus or the variety show, which allegedly lacked the required verbal sophistication, remain scarce. Although the middle classes constituted large segments of the audience of high and low culture, historians have continued to focus on their participation in high culture, thus over-emphasizing the social segregation separating the various cultural spheres. As this study demonstrates, no

32 See, among others, Wolfgang J. Mommsen, Bürgerliche Kultur und künstlerische Avantgarde. Kultur und Politik im deutschen Kaiserreich 1870-1918 (Frankfurt a. M., 1994).

33 Carl Dahlhaus, Die Musik des 19. Jahrhunderts (Wiesbaden, 1980); Marcel Beaufis Comment l'Allemagne est devenue musicienne (Paris, 1983); H. Fladt, Musik im 19. Jahrhundert. Aspekte bürgerlicher Musikkultur (Stuttgart, 1981); William Weber, "The Muddle of the Middle Classes," in 19th Century Music 3 (1979), 175-85; William Weber, "Mass Culture and the Reshaping of Musical Taste," in International Review of the Aesthetics and Sociology of Music 8 (1977), 5-21; William Weber, Music and the Middle Classes: The Social Structure of Concert Life in London, Paris and Vienna (New York, 1975); Ute Daniel, Hoftheater (Stuttgart, 1995). 
cultural genre exercised a monopoly on its audience's gaze; instead, ordinary Germans encountered a great variety of cultural media and cultural practices.

As Lawrence Levine has pointed out, the categories of culture employed by historians as well as contemporary observers reflect specific ideologies. ${ }^{34}$ West German historians especially have continued to take for granted a homogeneous German population with one cultural code, despite multiple attempts by historians interested in Alltagsgeschichte (the history of experience) or gender history to transcend these parameters. ${ }^{35}$ Most historians conceive of this cultural code as dominated by middle-class tastes and sensibilities. This assumption has contributed to the continuing fixation of historians on verbal cultural expression, since self-formation and learning were central to the moral economy of the middle class. Only recently has this hegemonic view of German culture been challenged. Today's persisting cultural divide between eastern and western Germany, even after legal unification, and together worth a more general recognition of Germany's importance as an immigrant society, have led some historians to challenge existing understandings of German culture and identity.

As with works in German cultural history, the historiography of German Jews has focused on expressions of bourgeois culture, primarily on the German-Jewish middle class and its achievements in science, philosophy, and the liberal arts. ${ }^{36}$ German-Jewish involvement in

34 Lawrence Levine, High Brow/Low Brow. The Emergence of a Cultural Hierarchy in America (Cambridge, MA,1988).

35 For a discussion of Alltagsgeschichte and its critics, see Jürgen Kocka, "Klassen oder Kultur? Durchbrüche und Sackgassen in der Alltagsgeschichte," Merkur, vol. 36 (1986), pp. 955-65, Martin Brozat, "Plädoyer für Alltagsgeschichte, " Merkur, vol 36 (1986), pp.1244-8; Franz-Josef Brüggemeier and Jürgen Kocka, eds., "Geschichte von unten Geschichte von innen. "Kontroversen um die Alltagsgeschichte (Hagen, 1985). In general see Lynn Hunt, ed., The New Cultural History (Berkeley, CA, 1989). Julius Schoeps, ed., Juden als Träger bürgerlicher Kultur in Deutschland (Stuttgart, 1989); Eszra Mendelsohn, "On the Jewish Presence in Nineteenth-Century European Musical Life," in Studies in Contemporary Jewry 9 (1993), 3-16. 
mass culture, acclaimed neither for its aesthetic aspirations nor for its creative superiority, has largely been ignored. Such a restricted focus on Jewish involvement in high culture partly reflects a widespread belief in the existence of a specific "Jewish intelligence," which represents the mirror image of the traditional antisemitic stereotype of the "Smart Jew. ${ }^{37}$ Many studies of German Jewry have echoed this inversion of the antisemitic stereotype. Afraid that the role of Jews in German history would eventually be forgotten, they focused on German Jews' contributions to high culture. Central to this "contributionist" paradigm were Jewish members of the cultural avant-garde as symbols of German-Jewish achievements and "superiority." Such a focus on elites and elite culture necessarily neglected those Jews who participated in mass culture, either as spectators or as performers. The popular Jewish entertainer who aimed his or her jokes at a mass audience has no place in this equation.

But not all Jewish entertainers aspired to be part of the world of Goethe, Lessing, and Schiller. Concentrating on intellectual and economic elites, previous research has tended to treat the Jewish community as a monolith. ${ }^{38}$ An analysis of German popular entertainment paints a more complex and heterogeneous picture. German Jews were drawn from all classes and participated in many different subcultures, which were by no means exclusive. Jews figured prominently in the constitution of new realms of entertainment and had a major impact on tastes and aesthetics in German mass entertainment at large. In short, there was no pre-existing, homogeneous German mass culture into which Jews chose to assimilate. Instead, mass entertainment evolved in conjunction with the massive involvement of Jewish actors, artists, directors and screen writers. All of these participants were closely involved with the continuing process of creating new styles of presentation and stage techniques. This does not mean,

37 Sander Gilman, Smart Jews. The Construction of the Image of Jewish superior Intelligence (Lincoln/Nebraska, 1996).

38 David Sorkin's work is one example for this long-standing tradition of focusing on Jewish intellectuals, in the attempt to analyse Jewish culture. David Sorkin, The Transformation of German Jewry 1780-1840 (New York, 1987). 
however, that Jews qua Jews were at the forefront of a progressive and experimental avantgarde culture. ${ }^{39}$. Instead, they could be found in all spheres of entertainment, occupying various class positions as theater moguls or circus acrobats. They staged old-fashioned, folksy massproductions, as well as avant-garde ones. Thus no single and unifying identity can be attributed to Jews involved in the cultural sphere. This study explores the great variety in Jewish involvement by focusing on Jewish families and individuals who were more representative of general developments in German mass entertainment than historians have until now believed.

\section{Approach}

This study is divided into three main sections, which are based on three entertainment genres. The first section deals with German-Jewish circuses; the second is devoted to what contemporaries called Jargon theaters; and the third section analyses performers and performances in revue theaters. While the first section on circuses operates on a national level and does not primarily focus on one specific locality, the subsequent sections on Jargon theater and variety theater are set mainly in Berlin. One could, however, find equivalent theaters in other cities as well. Furthermore, revues and family farces, the staples of revue and Jargon theaters, regularly traveled from one city to the other after they made their appearance in Berlin. All three sections in other words, relate individual families and artistic enterprises, because their successes and failures exemplify larger developments within each artistic genre.

Each section shares a common analytical progression, beginning with an interpretation of the artists' daily lives. Their family life and social milieu will be at the center of this part of

39 George L. Mosse made the influential argument that, during the Weimar period "the polarization of politics was accompanied by a polarization of culture. Jews seemed to take sides -- indeed, to play a visible and crucial role in encouraging the modern rather than the traditional." This assumption needs reconsideration. Although Jews were involved in the avant-garde movement, they could equally be found in the traditional camp. George L. 
the analysis. Thus the first part of every section explores the social history of popular entertainment. The second part of each section is concerned with the self-perception and selfpromotion of the individual artists. By comparing professional and private photographs, for example, one can explore how and why the private and public personae of Jewish entertainers were interconnected, and where they differed. One learns how Jewish entertainers viewed themselves and how they thought they appealed most successfully to their audiences. A similar comparison of their private written records on the one hand, and the way they advertised themselves on the other, leads to a better understanding of the dilemmas confronted by Jewish entertainers who tried to reconcile their sense of self with a marketable image.

These two parts provide the necessary background for the final layer of analysis: an examination of the aesthetics that Jewish entertainers chose to present to their audiences. A detailed discussion of styles and cultural symbols complements the discussions of the social reality and reception, of the social and the imagined. A discussion of aesthetics and Jewish identity in mass entertainment is not about finding "Jewish" artifacts in mainstream art, nor defining a Jewish form of art; rather it is about motivation, and the meaning attached. This requires a discussion of the contemporary political and social context, an historical context larger than the realm of popular culture.

To provide a multifaceted view of Jewish identities it is necessary to move beyond the approaches prevalent in most studies of popular culture. Typically these studies focus either on the production or on the reception of popular culture. Only a combination of both approaches, however, allows a complex analysis. Until now historians have failed to explore the relationship between the social history of performers on the one hand and their particular aesthetic on the other. Yet new insights into the ethnic dimension of the production and consumption of culture can best be gained through a close examination of the interdependence of these two components of mass entertainment. It remains to be determined how social factors

Mosse, German Jews beyond Judaism (Bloomington, 1985), 22; for a similar view to 
such as territory, language, and the religious practices of circus performers affected their sense of self. We have to explore the impact that geographic and social mobility and the relationship between generations made on the reception and self-perception of performers. Furthermore, social factors such as fertility rates, intermarriage, gender relations, and questions of sexuality conditioned the aesthetic of performance acts. This study conceives of the questions and theoretical concepts of modern social history as necessary to provide a base for an analysis of cultural symbols. For in the realm of popular entertainment, there are many voices to be heard. Each analytical framework provides a different set of questions which casts a different light on the issue of Jewish identity in popular entertainment.

\section{Structure of the Study}

The three sections that make up this study - circuses, Jargon and revue theaters -- are not only distinct in terms of the aesthetics of their genres, but also represent different stages in the acculturation of Jewish artists. The order of these sections is based less on chronology or aesthetics than on how Jewish entertainers interacted with society at large. The specific entertainment enterprises to be examined were chosen because each one -- in its prime -- set trends for others in the business. This study will begin with a discussion of the Blumenfeld, Lorch and Strassburger circuses, which were run by prominent Jewish families in the late nineteenth and early twentieth centuries. This will be followed by a discussion of the Folies Caprice and the Gebrüder Herrnfeld Theater, two major Jargon theaters in Berlin. The study will conclude with an examination of the Metropol Theater, the most successful revue theater in Wilhelmine and Weimar Germany. ${ }^{* 0}$

Mosse's, see Walter Laqueur, Weimar Culture (New York, 1974).

to The Metropol theater has fascinated contemporaries and historians alike. For the best scholarly discussion in English, see Peter Jelavich, Berlin Cabaret (Cambridge, MA, 1993); other treatments include Wolfgang Jansen, Das Varieté: Die glanzvolle Geschichte einer unterhaltenden Kunst (Berlin, 1990); Wolfgang Jansen, Glanzrevuen der zwanziger Jahre 
Change, mobility, and interdependence are important characteristics of German popular entertainment. Most medium-sized cities had several music and variety theaters, not to mention many cabarets, whose shows started in Berlin, Hamburg or Munich, and toured all over the German Empire. Similarly, actors and acrobats were by no means settled in one city but moved often in the course of their careers, some even several times a year. Their mobility was by no means restricted by national boundaries. A steady flow of entertainers from America, France, Poland and Austria entered Germany. In fact, in the late nineteenth century, and especially in the 1920s and 1930s, a fairly constant stream of American and European performers crisscrossed the Atlantic, leaving their imprint on the acting, directing, and musical worlds of their host countries. ${ }^{41}$ Thus the fluid nature of the entertainment industry is apparent not only in the physical mobility of its participants, but also in performance styles and contents.

Because of this fluidity, popular entertainment defies clear-cut definitions. Many drama theaters began as stages for variety entertainment. With growing popularity, these variety

(Berlin, 1987); Ingrid Heinrich-Jost, Sehn Sie, das ist ein Geschäft, Auf ins Metropol, Spezialitäten- und Unterhaltungstheater im ausgehenden 19. Jahrhundert, Ein Kapitel Berliner Kulturgeschichte (Berlin, 1983); Emst Günther, Geschichte des Varietés (Berlin, 1981); Reinhardt Klooss and Thomas Reuter, Körperbilder: Menschenomamente in Revuetheater und Revuefilm (Frankfurt a. M., 1980); Franz-Peter Kothes, Die theatraliche Revue in Berlin und Wien 1900-1938: Typen, Inhalte, Funktionen (Wilhelmshaven, 1977); Walter Freund, "Aus der Frühzeit des Berliner Metropoltheaters," in Kleine Schriften der Gesellschaft für Theatergeschichte 19 (Berlin, 1962); contemporary accounts of the fame of the Metropol theater were D. Duncker, "Das Metropoltheater und die Berliner Revue," in Bühne und Welt 10, 44.

41 This exchange was remarked upon by contemporaries, see among many Fritz Giese, Girlkultur, Vergleiche zwischen amerikanischem und europäischem Rhythmus und Lebensgefiihl (Munich, 1925). The interdependence of artistic scenes has received considerable attention in the realm of film; most historians remain unaware, however, that an equally intense exchange occurred prior to the rise of the film industry. For a recent study see Thomas J. Saunders, Hollywood in Berlin. American Cinema and Weimar Germany (Berkeley, 1994). 
theaters began to favor one-act shows and eventually mounted "serious" theater productions. Other drama theaters came to experiment with literary cabaret performances for small and large audiences. In 1910, the famous theater director Max Reinhardt even used a circus to stage monumental drama. ${ }^{\$ 2}$ The interconnectedness of the various genres in live entertainment in early twentieth century Germany is also reflected in the fact that actors and directors knew each other and entertained friendships and business relations across artistic genres.

The four chapters included in Section I examine German circuses. From the 1870 s to the First World War, the circus was the main form of mass entertainment in Germany. German circuses in the early twentieth century were extraordinary both in terms of the heterogeneity of their audiences -- which included social elites as well as "the masses," men and women, adults and children -- and in terms of their sheer magnitude. The circus was the first form of entertainment to draw a public that was broadly representative of society as a whole. By the turn of the century, Berlin, the capital of entertainment, was able to host several permanent circuses, which performed in front of some 5,000 spectators every night. Circus entertainment was not confined to the capital alone. Most larger cities such as Hamburg, Munich, Dresden, Magdeburg and Breslau accommodated at least one permanent circus. Other cities received traveling circuses several times a year for several weeks at a time. Most circuses staged two or three productions a day, six days a week, fifty weeks a year.

\$2 Reinhardt staged the grand classical drama Ödipus in a former circus arena, which he then called "the theater of the 5000" (Theater der 5000). In 1919 the circus Schumann was designed by the famous architect Hans Pölzig, a member of the Bauhaus movement, to host the grand theater of Berlin (Großes Schauspielhaus). This theater existed until 1933, when it was closed by the Nazis. For an interesting account of the contemporary debates on this experiment see F. Baumgarten, Zirkus Reinhardt (Potsdam, 1920), more recently Eva Tilgner, Das Haus an der Spree. Von der Markthalle zum Friedrichstadtpalast (Berlin, 1974); Wolfgang Carlé Das hat Berlin schon mal gesehn. Eine Historie des FriedrichstadtPalastes (Berlin, 1982); for an account of Reinhardt's own ideas see Hugo Fetting, ed., Max Reinhardt .Schriften, Briefe, Reden, Aufsätze, Interviews, Gespräche, Auszüge aus Regiebüchern (Berlin, 1974). 
Circuses were also exceptional because of their unprecedented respectability. They transformed the arena into a world of precision and beauty, answering the needs of a society that was beginning to pay increasing attention to middle-class values such as punctuality, discipline and cleanliness. ${ }^{43}$ It was this respectability that allowed women to become an integral part of the audience and turned the circus into a public forum where people socialized, and where they could see and be seen. ${ }^{4}$ In their splendor and magnificence, circus buildings could easily compete with, and often surpass, the leading theaters of the time. Circus directors took pride in the crystal chandeliers illuminating their stables, just as they cherished the heavy carpets that softened the footsteps of the admiring visitor -- who in turn marveled all the more at the beauty of the exquisite horses and the menagerie of exotic creatures. Circuses were run as modern capitalistic enterprises with an annual budget of several million marks. The directors of these enterprises were prominent public figures with a local and national reputation, whose presence in the "collective mind" of the German population can only be compared to the film and sport heroes of the late twentieth century.

${ }^{43}$ Robert A. Jones, Art and Entertainment: German Literature and the Circus, (Heidelberg, 1985), 13; similarly the contemporary journalist Karl Döring in his review: "It shall be briefly mentioned that the great pioneers of circus art were the French Louis Dejan and the German Altmeister Emst Renz. Dejan was the first to break with the vagabond style and the miserable presentation, introducing a respectable organization of the entire enterprise. One of his very popular direction to the ticket vendors and inspectors was: 'A Messeurs les billeteurs: Demain frac noir, cravatte blanche, gilet glane, pantalons noir au talon d'or.' His orchestra always performed in full evening dress. Renz observed theses refinements. His accomplishments could compete with Dejan, and in addition he introduced the latter's flawless presentation, and thus emerged victorious in Berlin and in Germany at large." Karl Döring, in Das Programm, no. 1168, August 24, 1924; documenta artistica collection in the Märkisches Museum, Berlin.

* Tony Bennett descibed a very similar development in museums. Tony Bennett, "The Exhibitionary Complex," in idem, The Birth of the Museum. History, Theory, Politics (London, 1995), 59-88. 
The circus was the most universal and yet also the most ambiguous of the three entertainment genres examined in this study. It merged past and future in a unique way. Traditional elements were interwoven with modem elements in a manner very different from that attempted in any other form of entertainment. The circus was always both "within" and "outside" society. ${ }^{45}$ This ambiguous nature of the circus enabled former social "pariahs" such as traditional German Jews to flourish between the 1890s and the First World War. Key to the extraordinary success of Jewish circus performers was their preservation of the social structure of the traditional Jewish orthodox family. For a long time hierarchical structures remained perfectly compatible with the demands of their industry, and Jewish circus families were able to establish themselves permanently in the realm of German circus entertainment. Ironically, it was their "pre-emancipatory" traditionalism, reflected in the organization of their enterprises as well as in the aesthetics of their shows that enabled these families to succeed in the modern entertainment industry. Their apparent lack of assimilation was in itself a highly successful adaptation to the demands of turn-of-the-century mass entertainment.

In the course of the First World War, however, circuses owned by German Jews did not take the changing tastes and sensibilities of their audiences into account. Their family structure and their belief in hierarchy, responsibility, order, and collectivity did not correspond to the brutalization of Germany's entertainment sphere. Consequently, many of these circuses collapsed in the immediate post-war period. Despite a rising fascination of German spectators with so-called "death artistry" (Todesartistik), Jewish circus directors held on to their traditional horse acts, because they perceived the horse to be an integral component of their ethnic identity. The horse had symbolized three different social factions -- the landowners, the nobility, and the military -- all of which had been closed to German Jews in pre-emancipatory times. Accounts of their father's generation still recalled this past. Jewish circus performers, born shortly before 1869 , grew up as the first generation to enjoy legal equality, guaranteed by

4 Paul Bouissac, Circus and Culture. A Semiotic Approach (Bloomington, 1976), 7. 
their German citizenship. Hence, this generation clung to the horse as a reminder of their emancipatory successes and as a visible expression of their personal pride and achievements. Even when confronted with bankruptcy, they were unable to give up this vision.

In Section II we turn to Jargon theaters in Berlin. The focus falls on the Gebrüder Hermfeld Theater, founded in 1896. As the only popular Yiddish theater in Berlin with a longstanding history, the Herrnfeld theater is often assumed to have been the last refuge of Germany's unassimilated Jews. As such, it is often excluded from discussions of mainstream entertainment. ${ }^{46}$ But the Hermfeld theater, as well as its imitator the Folies Caprice, was popular among Gentile and Jews alike and a favorite locality for amusement and distraction for bourgeois clubs and associations. Both Gentiles and Jewish Berliners were captivated by the awkward and sometimes crude one-act sketches that inevitably revolved around themes such as family disputes, adultery, and rejected love. These plays were caricatures of "serious" theater. They mocked but did not question the middle-class ethos and life-style -- its hypocrisy and gender relations as well as its nationalism and politics. These theaters were not expressions of an unassimilated Jewish subculture, catering to the needs of an orthodox Jewry in search of cultural reaffirmation. Nor did Jargon theaters intend to feed antisemitic sentiments among one segment of the lower middle classes. Instead, Jargon theaters were part of an urban middleclass amusement scene of which Jews constituted an important part.

This study argues that Herrnfeld theater performances reflected a consensus among the German urban middle classes to view German Jews not exclusively as "outsiders," but as one of the many "tribes" constituting the German nation. Just as Bavarians or Swabians were seen to possess a distinct culturally defined "tribal" identity, mocked in the many folk theaters at the time, so were Jews seen to form a similar close-knit group, whose membership did not conflict with their national allegiance. The folkloric depiction of the daily lives of Jewish families suggested that their lives were in fact very similar to that of other Germans: unfaithful 
husbands quarreled with their petty wives and their self-righteous mothers-in-law; ambitious young men courted unworldly young women. The particularity of the "Jewish milieu" thus held a real appeal for the German middle-classes. Moreover, "Jewish accents" were parodied mostly in conjunction with similar jokes about Bavarian or Bohemian accents, suggesting they were seen on an equal footing. The form and content of Jargon theaters imitated the many popular folk theaters of the time, emphasizing the parallels with other expressions of the same Volkskultur. Humorous references to various regional and ethnic identities were intended to reinforce a sense of community. It was the inclusive nature of Jargon theaters that contributed to their appeal.

The moment cultural diversity and coexistence were renounced and replaced by a call for conformity in the course of the First World War, this appeal was lost. Once the Kaiser appealed to the nation with the words "I no longer recognize parties; I only recognize Germans," Jews found themselves to be outsiders again. The German army's "Jewish census" (Judenzählung) of November 1916, a census that was meant to determine whether Jews were shirking their military obligations and were engaged in large-scale profiteering, constituted a turning point in Jewish-Gentile relations in the early twentieth century. ${ }^{47}$ Indirectly it also contributed to the demise of Jargon theater entertainment.

Section III of this study focuses on revue theater in Berlin. While many Jewish performers maintained a high profile in the realm of circus entertainment and Jargon theaters, others were successful in the realm of revue theater. Jews played a major part in most revue productions. Scripts and tunes were written, composed and performed by Jewish artists, to be presented to a partly Jewish audience. Unlike Jewish circus performers, Jewish entertainers engaged in revue entertainment ceased to identify themselves with traditional Jewry. Actors and

46 Michael Brenner's study, The Renaissance of Jewish Culture in Weimar Germany (New Haven, 1996), is one of the most recent examples of this assessment.

47 Werner T. Angress, "The German Army's "Judenzählung" of 1916. GenesisConsequences - Significance," in Leo Baeck Institute Year Book 23 (1978), 117. 
artists were neither explicitly religious nor particularly oriented towards family. In any case, they conspicuously refrained from public statements in this direction. Jewish actors at the Metropol theater, Berlin's most important revue theater, did not care to play Jewish characters on stage. Jewish jokes and references to Jewish stereotypes, however, were staples in revue theaters during the Wilhelmine period.

The pre-war Metropol revue was not meant to teach, provoke or polarize its audiences, but to amuse and distract demanding spectators. Berliners -- Gentiles and Jews -- were eager to celebrate themselves and their city, and the Metropol accommodated this desire. The idealization of the capital bridged potential political or ethnic gulfs among a diverse spectatorship. Local pride and national patriotism, lightly presented with Berlin wit and in the Metropol's sentimental spirit, transcended religious and political antagonisms.

These revues faithfully mirrored Jewish stereotypes circulating among Berlin's upper classes. Depending on Germany's social and political climate, its Jewish characters were painted in a more or less positive light, partly sarcastic and partly affectionate. Most of these characters had a decidedly eastern European background; their unpolished manners and clumsy ways were the source of much ridicule and laughter at the Metropol theater. To avoid offending its wealthy Jewish clientele, the Metropol distinguished sharply between the established Jewish community and members of the "Jewish milieu." While we can hardly find references to upperclass Jews in the Metropol revues, "half-assimilated" Jews appeared in abundance. Aligning itself to Gentile upper-class humor, the "little Mister Cohn" was the "ideal-type Jew" at the Metropol theater. Such depictions of Jewish characters were unflattering and at times vulgar; but they were not intended to stir up racial hatred. Rather, they were part of the metropolitan mosaic. These jokes did not allow the spectator to forget that a complex relationship existed between those who were being caricatured and their Gentile environment (not least because predominantly Gentile actors impersonated Jewish characters). These unflattering Jewish characters were the price Berlin's wealthy Jews paid for having entered the arena of upperclass Berlin. 
Revue theaters such as the Metropol made popular entertainment attractive and acceptable for Berlin's traditional elites, such as the military, the court and the nobility. By the turn of the century, these elites more than ever needed the affirmation of society at large. The Metropol provided a new forum of upper-class sociability that allowed these traditional elites to mingle with members of the Wirtschaftsbïrgertum, the administration, the arts and the press. Wealth and merit became the distinctive qualities for social status in this new sphere of sociability, overshadowing, if not replacing, former qualities such as birth. The greater transparency of this new arena in Berlin's night-life opened up new possibilities for successful members of Berlin's established Jewish community to find partial inclusion in the capital's elite circles.

The Metropol allowed these elite circles to visibly exercise exclusivity and distinction at the special occasions of seasonal premieres and annual balls. By contrast, middle-class Berliners, who aspired to such glamor visited the Metropol at its more mundane (and less costly) regular shows. By catering to two audiences at once, the elite audience and the middleclass audiences, the Metropol not only secured financial success based on a wide clientele but also preserved its aura of glamour and exclusivity. Jews could be found among both the upscale audience and the regulars. Thus theaters such as the Metropol were instrumental in the formation of a new public arena that allowed wealthy Jews to gain inclusion into Wilhelmine society, either as members of the premiere audience, celebrating themselves at the masked balls, or among the regular spectators eager to rub elbows with the elite circles at one of the regular shows at the Metropol.

Considering the three genres discussed in this study, we see that each of them sheds very different light on the question of Jewish identity in German live entertainment. The Jewish artists involved in circuses, Jargon- and revue theaters represent different stages of Jewish acculturation in the cultural sphere. Each group of artists developed different strategies in their attempt to accommodate their ethnic identity to mainstream entertainment. This study demonstrates that there was not one Jewish identity alive in Germany's public sphere, but 
many identities. To be sure, the analysis will move from a discussion of traditional Jewry in circus entertainment, to popular Jewish theater in Germany's capital, to conclude with a discussion of highly assimilated entertainers in upper-class revue theater. Nevertheless, one must stress that each of these genres was affected by the general social and political climate in Wilhelmine society; each was shattered by the traumatic experiences of the First World War; and each struggled to reestablish itself in the post-war period. Jewish artists in circuses, Jargon- and revue theater developed differing rapports with their respective audiences. This study explores how and why Jewish artists in each genre entered into the dialogue with their Gentile and Jewish audiences, and how this dialogue was influenced by social and political factors within and beyond the cultural sphere. 
I Jewish Identities in Circus Entertainment, 18701927 


\section{Chapter 1 The Circus in Time and Space}

Between the 1870s and the First World War, the circus was the main form of mass entertainment in Germany, drawing mass audiences fascinated by its imaginative world of spectacle and illusion. Even though circuses today have become a nostalgic event for audiences of small children, they exerted a considerable influence on press, arts and fashion at the time.' Now museums and archives preserve the memory of a medium that is no longer "organic to our mass-culture." Such showcases display the haunting remains of a world once populated by an exceptional variety of artists with different racial, religious and national identities. ${ }^{2}$ To excavate this lost world of the circus, one must pay special attention to the human protagonists of this world, the members of German-Jewish circus families.

For half a century, Jewish circus families dominated and shaped circus entertainment in Central Europe. To understand their exceptional rise in the late nineteenth century as well as their dramatic decline in the 1920 s, one must consider how circuses gained such a tremendous following in the late nineteenth and early twentieth century; why spectators went to the circus; and who these spectators were. Furthermore, we have to examine what equipped Jewish circus families to particularly succeed in a new entertainment sphere, when other circus entrepreneurs failed.

Jewish circus families favored a specific aesthetic that matched their particular social structure as well as their dreams and aspirations. To understand their specific choices one has to examine the history of circus entertainment. The following chapter establishes the historical

1 Paul Bouissac, Circus and Culture: A Semiotic Approach (Bloomington and London, 1976), 8-9.

2 Robert A. Jones, Art and Entertainment: German Literature and the Circus, 1890-1933 (Heidelberg, 1985), 9. 
framework for such an analysis, locating the rise of the circus within the context of social and economic change in Germany. Chapter two discusses the daily life of Jewish circus families, their social structure, and specific family practices. Chapter three analyzes the way Jewish circus families presented themselves to their audiences, and how they were perceived by the German public. This section concludes with a fourth chapter on the specific aesthetics employed by German-Jewish circuses.

At the turn of the century, the definition of circus entertainment, its aesthetic roots and traditions prompted contemporaries to reflect on its relationship to classical art forms. To assess its status vis-à-vis the arts and culture, contemporary historians debated whether the circus could be traced back to the Roman circus plays and the first Olympic games, or whether in fact the circus was a product of modernity. ${ }^{3}$ Contemporary advocates of the circus searched to establish a link to the "classical age" in order to legitimate an entertainment genre that fascinated thousands all over Europe. Nineteenth-century circus specialists claimed that the circus was older than civilization, precisely because it was denied inclusion in the definition of "high" culture."

Whereas these experts were strongly inclined to point to such continuities, today's historians tend to stress the differences between the Roman circus and the modern circus. Nineteenth-century European circuses differed considerably from Roman circuses in size, function, and aesthetics as well as in reception. Roman games were held in varying localities in

3 It seems safest to take the concept "circus" literally. It stemmed from the round form of the arena. The word "circus" has Greek origins describing a round or oval shaped arena, "a place where games are held." Eduard Schmitt, Handbuch der Architektur. Vierter Teil. Entwerfen, Anlage und Einrichtung der Gebäude. 6. Halbband, Gebäude für Erziehung, Wissenschaft und Kunst. 6. Heft, Zirkus-und Hippodromgebäude (Stuttgart, 1904), 4.

4 One expression of this desire is their frequent use of the Latin spelling circus instead of the German spelling Zirkus. Since the late eighteenth century the German spelling came to be the dominant one. In the nineteenth century, mainly academics held on to the Latin spelling. 
front of an audience of sometimes up to 100,000 spectators. ${ }^{5}$ The modern circus performed in a ring surrounded by a crowd of 2,000-5,000 individuals. ${ }^{6}$ As slaves, Roman artists were not part of a market economy in which they could freely promote their talents. Patrons controlled most of their movements and sponsored their specific training. Roman circuses were to some degree populist attempts of the ruling elite to gain a following among the masses and were financed and supported by a small oligarchy. In comparison, modern circuses were capitalistic enterprises without a direct link to state authorities. On the contrary, state authorities tried their best to ignore the whole pinenomenon of popular entertainment. Moreover, the modern circus did not promote deadly gladiator fights, spectacular horse races, animal hunts, bullfights, or cultic sacrifices, although many performances in the modern circus purposely echoed some of these elements. ${ }^{7}$ These "echoes" were often motivated by a desire to legitimate the circus by providing it with a historical continuity that could not be matched by theater, opera or cabaret.

Today, most historians agree that the modern circus originated in nineteenth-century England. Several social, economic and technological innovations of the nineteenth century were essential for the circus to develop its ultimate expression: a "unity in variety," in the

5 Schmitt, Handbuch, 6.

6 Ibid., 15.

7 "As we all know, the Romans originally invented the circus. At first these circuses staged races, but slowly they became the sites of general amusement and spectacle, despite their differing lay out. More and more skills were in demand: Gladiator fights and animal hunts, fist fights and mock tournaments on horses, athletic games and much more. In conclusion we want to point out that ancient Rome knew many types of circus-type skills and arts." Dr. F. W. Bergen, "Zirkusleute... Ein kleiner Beitrag über Zirkusleute durch Generationen," in Das Programm no. 1315, June 19, 1927, 2; documenta artistica collection in the Märkisches Museum Berlin. 
words of the Soviet circus historian Jewgeni Kusneszow. ${ }^{8}$ One of these factors was the decline of trade fairs as a consequence of growing urbanization in Central Europe. Other factors included the establishment of a railroad network, an increase in leisure time, the commercialization of entertainment, and technological progress such as mobile circus tents (chapiteau) and electricity.

In its broad appeal the circus represented the first form of a mass medium, its audiences encompassing court, nobility and the military, men and women of the working and middle classes, as well as the peasantry. ${ }^{9}$ Walter Benjamin's description of the circus as a "sociological preserve" a "(somewhat frightening) space of class harmony" (Klassenfriedens) tried to encapsulate the extraordinary status of this genre within other forms of entertainment. Kusneszow's expression "unity in variety" thus comprises two meanings, and refers as much to the performances as to the audiences. Contrary to what is generally assumed, the circus did not exclusively serve the amusement of the lower classes. Instead, it was the first form of popular entertainment that integrated aesthetic elements of elite and popular entertainment. Inspired by military parades, riding competitions and theatrical elements, the circus popularized images and values which previously were confined to amusements of nobility and court society. These elitist elements in circus spectacle were combined with aesthetic elements stemming from fair ground amusements, such as acrobats, jugglers, magicians, animal trainers and comedians. It was this unique combination of aesthetic traditions that granted circuses such an exceptional appeal in the modern age. One could argue that at its apogee, the circus's place in society equaled the centrality of film or television in today's collective mind.

8 "The circus is untity in variety. It merges performances that differ in origin, form, character and content: acrobatics, clowns, horsemanship and animal training, technology and pantomimes." Jewgeni Kusneszow, Der Zirkus der Welt (Berlin, 1970), 7.

9 Walter Benjamin, Gesammelte Schriften, (Frankfurt a. M., 1972), review of Ramon Gomez de la Serra, Le Cirque. 


\section{The Rise of the Circus}

Radical socio-economic changes set the stage for the birth of the circus. One dimension of the modern circus had its roots in the side-shows at regional fairs. Since the sixteenth century, the importance of trading fairs had steadily increased. They remained important in Central Europe well into the nineteenth century. They supplied the population with goods not available locally, including necessities such as salt and luxury items such as coffee and precious metals. At these shows, acrobats, animal training, and clowning, the essential elements of a circus performance, did not suddenly appear at the end of the eighteenth century. Side shows of traveling jugglers, "wonder" doctors, puppet players, dancers, and tightrope walkers had long amused spectators at these fairs, offering them a break from the trials and tribulations of their lives with tricks and illusions, jokes and tales. ${ }^{10}$ Although animal trainers were common at these fairs, horse shows were rarely reported. In this early period, dressage and the demonstration of power over the animal were not central elements in the performances. Displays of exotic curiosities were more likely to fascinate the public. " A horse required substantial capital, and its acquisition and costly maintenance were more than many individual artists could afford. More importantly, its performance was based on its skills and less on its exotic appearance. The horse found its audience only once spectators began to appreciate such skills as discipline and precision.

10 See Enno Podehl, "Wandernde Puppenspieler und Bänkelsänger," in Fahrendes Volk. Spielleute, Schausteller, Artisten, exhibition catalogue, May 2 to July 4, 1981, Städtische Kunsthalle Recklinghausen.

II In 1443 the first elephant was put on display in Frankfurt, in 1515 a rhinoceros, and in 1584 a lion attracted the audiences in Nuremberg. Günther Bose and Erich Brinkmann, "Heimweh nach die Reise," in Fahrendes Volk. 
The decline and ultimate extinction of the regional trading fairs was an outgrowth of the rapid urbanization in various European regions during the nineteenth century. ${ }^{12}$ Traveling entertainers adjusted to the restructuring of the market and moved into the expanding cities, where they hoped to find new and receptive audiences. In most German cities, this process evolved irregularly and slowly compared to French or British cities. Fairs continued to flourish in many German states. ${ }^{13}$ Along the Rhine, for example, six hundred of them were still held during the nineteenth century. ${ }^{\mathrm{I}}$ Railway networks not only lowered industrial production costs and facilitated trade, they also increased mobility and eventually helped the circus to reach more people in less time. ${ }^{15}$ The replacement of the horse and cart with the train helped to set the stage for the "Golden Age" of the German circus in the late nineteenth century, which would last until the eve of the First World War. ${ }^{16}$

In addition to the railway network, the chapiteau (the mobile circus tent) was the most important technical innovation for the efficient movement of the traveling circus. In 1872 , when the first American circus came to Europe, it introduced the chapiteau, a contrivance which would revolutionize the European circus. Before its arrival, European circuses had only performed in stationary and often uncomfortable wooden arenas, especially built for the

12 See table 2-3 in Jürgen Reulecke, Geschichte der Urbanisierung in Deutschland (Frankfurt a. M., 1985), 202-204.

13 James J. Sheehan, German History 1770-1866 (Oxford, 1989), 485.

14 Ibid., 107.

15 Nuremberg and Fürth were the first German cities to be connected by rail line in 1835 . As Sheehan pointed out many of its passengers were Jews, who worked but could not live in Nuremberg. Sheehan, German History, 466; also Rainer Fremdling, Eisenbahnen und deutsches Wirtschaftswachstum, 1840-1979 (Dortmund, 1975); Rainer Fremdling and Ruth Federspiel and Andreas Kunz, ed., Statistik der Eisenbahnen in Deutschland 1835-1989 (St. Katharinen, 1995).

16 The term "Golden Age" ("Blütezeit des Zirkus") was first used by Joseph Halperson, Das Buch vom Zirkus (Düsseldorf, 1926), 127. 
occasion. ${ }^{17}$ Their construction was costly, their aesthetics usually unattractive. They remained unheated and immobile. The larger German circus enterprises reacted to the American challenge within a relatively short period by professionalizing their organization and improving their efficiency. The construction of the chapiteau demanded skilled workers, professional supervision, and capital -- three conditions German circus entrepreneurs were able to meet at the turn of the century. ${ }^{18}$

While the railway revolutionized the way circus people viewed dimensions of space, the chapiteau and electricity changed their measurement of time. The electrification, i.e. illumination, of the circus tent was another important technical improvement. ${ }^{19}$ Because artificial light allowed performances at night, the entire population could visit the circus even on work nights during the week. These changes affected audience as well as performers. They did away with a division into weekdays and weekends, and prolonged the work days of performers far into the night. While the rest of society enjoyed more and more leisure time, circus entertainers worked ever longer hours. They had to participate in three shows a day, to take care of their own equipment, and to ensure its adequate transportation and maintenance.

17 Schmitt, Handbuch, 15.

18 The tents of the larger traveling circuses (Pferdezirkus or Raubtierzirkus) were able to host up to 4000 spectators a night, two to three times a day, six to seven days a week. In 1930, Das Programm dedicated a whole article to these anonymous workers. "Von denen, die nicht im Zirkusprogramm genannt werden," in Das Programm, June 22, 1930, 28 ; documenta artistica collection in the Märkisches Museum Berlin.

19 The different opportunities on how to use light for special effects and to improve the show of the various acts were often discussed in the professional journals of the time, See for example: "Elektrische Scheinwerfer," in Das Programm, 1917, no. 517; documenta artistica collection in the Märkisches Museum Berlin. 


\section{Aesthetics}

The greatest aesthetic innovation of the modern circus was the centrality of the horse. The horse gave the circus its actual form and profile and became the quintessential symbol of the circus. All other acts were dominated by the equestrian display of beauty, nobility and vigor. The ring, the focus of the spectators' attention, was the central physical element of the circus. This basic structure always remained the same, whether the circus was held indoors, under a tent, or in the open air. The size and form of the arena was always thirteen meters and fifty centimeters in diameter. Only this measurement could guarantee a regular and steady movement of the horse, the crucial precondition for any acrobatic performance on horses. ${ }^{20} \mathrm{~A}$ ring of this size also provided maximal control of the equerry over the horse. He could remain at the center of the ring without losing touch with the horse, controlling all of its movements with his long whip. The whip also allowed the equerry to avoid running with the animal, a sight that might have undermined the demonstrated superiority of men over nature.

The centrality of equestrian performances was linked to the rise of modern nationalism, which had led to a change in the perception of the role and status of the military in European societies. A common soldier who in the seventeenth century was not met with respect by either the middle classes or nobility gained new importance in an era of national awakening. ${ }^{21}$ Among

20 Every irregularity in speed or rhythm inevitably endangers the safety of the artist, conducting somersaults, jumps through hoops or juggling a partner through the air. The small circle of 13 meters caused the speeding horse to tilt slightly inward towards the center of the circle, a favorable position for the artist to keep his or her balance. See G. Strehly, L'Acrobatie et les Acrobates (Paris, 1901), 298. More recently Günter Bose and Erich Brinkmann, Circus. Geschichte und Ästhetik einer niederen Kunst (Berlin, 1978), 36.

21 Michael Jeismann and Rolf Westheider, "Wofür stirbt der Bürger? Nationaler Totenkult und Staatsbürgertum in Deutschland und Frankreich seit der Französischen Revolution," in Reinhard Koselleck and Michael Jeismann, ed., Der politische Totenkult: Kriegerdenkmäler 
the military divisions, the cavalry experienced a specific rise in status. The early eighteenth century had witnessed a tremendous increase in the appreciation of the horse mainly on the part of the military. ${ }^{22}$ The central importance of the light cavalry in the maneuvers of European armies had led to a growing esteem of riding skills in German society at large. Among elites as well as the general public, the military rider represented the incarnation of "the gentleman." $\mathrm{He}$ rejuvenated the concept of the "chivalresque warrior," supplying both a new legitimization for the nobility and a popular hero for the masses. Thus, the image of the military riders combined new and traditional elements. The increase in prestige of the light cavalry was a consequence of the structural modernization of most European armies. Their technical modernization led to a reinvention of a military tradition, combining premodern and nationalistic ideologies. These acclaimed "Sir Lancelot types" were careful to portray themselves as archetypical noble warriors, fighting for both the crown and for the "people." They were often "blue-blooded, waspwaisted, mustachioed" womanizers as well. ${ }^{23}$ This new, "old" image was fundamental for their later successes in the realm of entertainment. In times of peace or retirement, these numerous cavalry men searched and found a new occupation and income displaying their equestrian skills. They represent the elitist element in the aesthetics of the modern circus.

Philip Astley (1742-1814), founder of the first circus in London in 1782, was one of these highly trained military riders. During the Seven-Years' War he had served in the light

in der Moderne (Munich, 1994), 24; Ute Frevert, ed., Militär und Gesellschaft im 19. und 20. Jahrhundert (Stuttgart, 1997); Jakob Vogel, Nation im Gleichschritt: Der Kult der "Nation in Waffen" in Deutschland und Frankreich 1871-1914 (Göttingen, 1997).

Dennis Edwin Showalter, "Prussian Cavalry 1806-1871: The Search for Roles," in Militärgeschichtliche Mitteilungen 19, no. 1 (1976), 7; also Sheehan, German History, 228; also John A. Lynn, The Bayonnets of the Republic. Motivation and Tactics in the Army of Revolutionary France, 1791-94 (Urbana and Chicago, 1984), chapter 9; Michael Howard, War in European History (London, 1975).

Showalter, "Prussian Cavalry," 7. 
cavalry. In London in 1772 shortly after he left the army, he set up the first "Riding School." To advertise for his new enterprise, Astley organized riding competitions for the general public. The nobility and the military in particular turned out to be a receptive audience for these equestrian performances. Trick riders gained entry to the court society and were even awarded titles, such as "his Imperial majesty's privileged horseman." The following description illustrates how much the army dominated the aesthetics of these amusements. The scene is Paris in 1775:

Mr. Hyam swings himself into and out of the saddle, he rides simultaneously on two horses. While standing solid with both legs on the saddle, he shoots the pistol at a full gallop. Standing on two horses, he loads the rifle, fixes the bayonet as if he prepares for attack, just like the cavalry before battle. He is able to stand on two horses and still keeps his balance, despite the jumping and galloping of the horse. ${ }^{24}$

These military riders eventually organized themselves into traveling riding societies and began to perform in open fields and public areas. At the end of the eighteenth century, such societies became part of the seasonal amusement in the bigger cities. The growth of the urban population in the nineteenth century allowed these riding societies to perform in one location for longer periods, sometimes several months at a time. A professionalization of their management led to the establishment of permanent arenas in the larger European cities in the early nineteenth century. The individual trick rider had become an entrepreneur.

Although the nobility and the military continued to exercise an important influence on public taste, their style did not monopolize circus performances. To be profitable, the latter had to cater to a wider public. Permanent residency forced circus directors to search for new attractions for a demanding audience. The artists and acrobats of the dying fairs provided them

${ }^{24}$ Ernst Günther and Dietmar Winkler, Zirkusgeschichte. Ein Abriß der Geschichte des deutschen Zirkus (Berlin, 1986), 13; citing Emile Compardon, Les Spectacles de la Foire, vol. I (Paris, 1877), 404. 
with a ready supply of talents and sensations. The tightrope walker exchanged his rope for a horse and the military trick riders began to pay attention to the theatrical elements in their acts. Acrobatics on horses came to integrate music and dance, the former cavalry men were now concerned with questions of aesthetic appearance, choreography and mimic expressiveness and arranged their equestrian acts according to a loose narrative. From the beginning, these pantomimes combined fact with fiction. They appealed to the public's desire for romance, tragedy, and chivalry. Indeed, in many ways they were a lavish mixture of sensual fairy tales and explicit political propaganda.

Fundamental social change and upheaval was necessary to finally bring about the circus as an independent entertainment genre. The French revolution and its aftermath was the catalyst for the modern circus. Astley's early enterprises were still called "amphitheaters," not circuses. Their owners, including Astley, defined themselves as integral parts of "high" society and thus aspired to preserve the exclusive nature of their establishments. That exclusivity was not necessarily reflected in the social fabric of their spectators, but primarily in the habitus of their protagonists. This first generation of directors, however, was succeeded by a "popularized" generation such as the "citizen Franconi" in Paris, an apprentice of Philip Astley. Franconi was much less concerned with the entertainment of elites only but sought to establish the widest popular appeal. When Napoleon forbade any artistic enterprise involving animals and acrobatics to refer to themselves as theaters in 1807, Antoine Franconi (1737-1836) began to promote his establishment as a "Cirque Olympique." ${ }^{25}$ His enterprise served as the prime example for his many successors all over Europe.

This change of name indicates two important points in the history of the circus. First, although circus performers socialized with princes, kings, and queens, the circus as an artistic 
genre did not acquire the status of art. After a short period of relative artistic freedom during the early Napoleonic years, the French administration, along with most European states, devoted considerable attention to the consolidation of a cultural hierarchy that casts its shadow well into the twentieth century. Second, in opposition to these official attempts to monopolize cultural norms and values, circus entertainers and entrepreneurs exhibited a growing self-confidence, which was fueled and legitimated by the enthusiastic responses of audiences. Such audiences helped to establish a market that was constantly growing in size. Mass entertainment reacted sensitively to changes in the political climate: Franconi's choice of names was a direct expression of such a shift of values in public opinion. In the course of the French Revolution and its aftermath, an idealized recollection of Roman times became more influential in the political arena and replaced the striving for social exclusivity in the earlier years. The Roman theme in French public opinion carried strong connotations of democratization and liberty; and the circus appeared to be its ultimate expression.

\section{Reception of the Circus}

A constant theme in the history of the circus has been the wide gap between the perception of the circus and its social structure, in other words the perspective of the spectator compared to the social realities of the actors, the outside and the inside perspective. For the spectator, the seemingly equal status of the different acts was a dazzling experience. The quickly changing scenery kept the audience attentive, the public found its surprises enjoyable. The audience's desire for "liberty" and movement was also reflected in the aesthetics of the performances. The

25 Antonio Franconi was born August 5, 1737 in Undine, Italy. See Walter Ulrich, Daten aus der Circuswelt, Gesellschaft der Circusfreunde in Deutschland, ed., Manege: Eine Schriftenreihe für Circusfreunde, vol. 4 (Berlin, n.d.), 21. 
modern circus provided a unique opportunity to view human bodies, both male and female, in a relatively unrestricted fashion.

Unlike variety shows and strip bars (Amüsierkneipen), the circus was not taboo for respectable women. It was in fact the only opportunity for women to see a scantily dressed body in detail without compromising themselves. Many have pointed to the enchantment of male spectators with female performers, documented in the writing of Gerhard Hauptmann and Frank Wedekind and in the paintings of Toulouse Lautrec or Edgar Degas. But little has been said about how female spectators viewed these acts. Since many spectators were women, their perception has to be taken into account as well. ${ }^{26}$

To contemporaries, women's possible reactions to partial nudity seemed more threatening, unpredictable and therefore more uncontrollable than those of the male spectators. The ruling elites of society were particularly concerned about the female exposure to eroticism. In the course of the eighteenth century, for example, the Empress Maria Theresa threatened to banish the attractive trick rider Hyam if he did not refrain from arousing the Viennese women. ${ }^{27}$ Similarly, Paula Busch, a legendary circus directress from Berlin, recalled that her father's artists used to have two sets of costumes during the Imperial period, one with a high collar in the case of the Empress' presence, and one with a plunging neckline for all the

26 Although recent scholarship on film has addressed the question of female spectatorship, little has been done for the genres preceding film and television. For an excellent overview of literature and current debates, see Judith Mayne, Cinema and Spectatorship (London, 1993). Recent works on female spectatorship are Jackie Stacy, Star Gazing: Hollywood Cinema and Female Spectatorship (London, 1994); Miriam Hansen, Babel and Babylon: Spectatorship in American Silent Film (Cambridge, MA, 1991), as well as Janet Bergstrom and Mary Ann Doane, eds, "The Spectatrix," Camera Obscura (May-September 1989), 20 21.

27 Halperson, Buch, 38. 
remaining performances. ${ }^{28}$ It was perceived to be the function of the first ladies, as the "mothers of the nation," to defend the moral standards of society and to watch over any "unruly" behavior of their female subjects, in the ring as well as in the audience.

The circus challenged traditional gender roles. It did not clearly divide men and women into subjects and objects, with men acting and women being observed. Women in the audience watched the performances of a muscular Hercules with great attention. Male and female specatators alike viewed acrobats as objects of desire. Male and female circus performers combined apparently contradictory images of male and female stereotypes. Paula Busch captured this tension:

The woman, who is able to appreciate beauty more purely and impersonally, is enthused by the nobly built body, the slender limbs of beautiful acrobats and herculesses or the nymph-like figure of a horsewoman, just as she is by a beautiful picture. Yes, such a circus horsewoman, trained since her youth, combines female grace with manly strength and courage. ${ }^{29}$

28 "Often the empress, her children and their friends attended a Sunday afternoon show. As everybody knows, the empress Auguste Victoria held strict moral views. My father knew that and at the rehearsal the night before the actual visit, Count von Mirbach never found anything to complain: The female swimmers on the shining fountain wore closely knit veils over their 'Venus'-costumes. The circus tailor had altered the ballet dancers' necklines by five centimeters, the jockey girls had exchanged their short little jackets for Cossack uniforms. At the 'special performances,' the audience amicably overlooked these disguises, which made some acts in the water or on horseback virtually impossible. It stood up enthusiastically when the empress entered the royal box, presenting an image of warmhearted motherliness." Paula Busch, Spiel meines Lebens (Berlin, 1992), 48.

Paula Busch's essay about women in the circus, written in the first decades of the twentieth century is an exceptional source. She discussed four different reasons why a woman could enjoy the circus. The first point seemed to be a concession to the public's expectation: the woman goes to the circus to see her children happy, since it is a unique place to see wild animals as well as well trained horses. In Paula Busch's eyes the real reason for the 
Paula Busch captured the first symptoms of challenges of male cultural authority in the eyes of circus spectators. This development came most apparent when authorities and middle class associations came to worry about women's relationship to filmed images. The control of the voyeuristic pleasures found in dark movie theaters became a concern shared by many (male) contemporaries. ${ }^{30}$

The inner world of the circus was not at all as the audience imagined it to be. Behind the scenes the circus was neither democratic nor sexually permissive. Its social structure was organized in a hierarchical way, somewhat reminiscent of a "caste" system. The owner's family constituted the inner circle, headed by the director and his eldest son, the "crown prince" of the circus empire. The circus director was omnipotent and his authority resembled that of the "enlightened despot." ${ }^{31}$ The seasonal workers, his footmen, so to speak, floated on the periphery of this microcosm, and were mainly responsible for the handling of the equipment. The larger enterprises had highly organized and well-outfitted crews, the so-called Pfälzer and Böhmen. ${ }^{32}$ The acrobats and hired artists provided the link between these two factions.

presence of women was their superior sensitivity to the sexual undercurrents of most circus acts. Paula Busch argued that the erotic tension in the circus act could be felt more strongly by a woman than by a man. "Die Frau im Zirkus," Ms., Circus-Busch-Archiv Berlin. Patrice Petro, "Perception of Difference: Woman as Spectator and Spectacle," in Katharina von Ankum, ed., Women in the Metropolis. Gender and Modernity in Weimar Culture (Berkeley, CA, 1997), pp. 41-66; Andreas Huyssen, "Mass Culture as Woman: Modernism's Other," in Tania Modleski, ed., Studies in Entertainment: Critical Approaches to Mass Culture (Bloomington, 1986), 188-207.

31 Karl Döring, "Zirkus Reform," in Das Programm, no. 1168, August 24, 1924; documenta artistica collection in the Märkisches Museum Berlin.

For decades these seasonal workers were recruited out of Bohemia and the Palatinate. Skills and knowledge were handed on from father to son, from one generation to the next, providing the necessary stability and continuity in manpower for the circus enterprises. These workers were segregated from the rest of the circus personnel not only through the 
Social control within the circus was not, however, exerted by the director alone, but was woven into the social fabric of the circus in a sublimated form. This was a consequence of the circus's isolation from the rest of the population, and its being constantly on the move. Young unmarried women especially were submitted to a strict regime. They slept apart from the men in a special wagon chaperoned by an older woman. Their daily routines were strictly regulated, mainly divided between training sessions, communal meals, traveling preparation, performances, and sleep. Contact with the male public was forbidden, and romantic involvement with men of the crews was not permitted either. Both situations potentially endangered the women's value for the circus, as well as the reputation of the circus in the public eye.

\section{The "Golden Age" of German Circuses}

In nineteenth-century German cities, a large spectrum of the population had not yet acquired an urban mentality, but clung instead to their traditional customs. In a unique way, the traveling circus shows catered to the need for both familiarity and cultural traditionalism. At the same time they played off the feelings of displacement and nostalgia among their audiences. In the course of urbanization, the circus profited from the increasing leisure time of its potential

lower status of their work, but also because of their origins. The Bohemian workers in particular communicated only in their native language. When the well-known Circus Strassburger in 1910 searched for a new equerry (Stallmeister) and Stallsprechmeister, one of the main requirements was the knowledge of the Bohemian language. See Herbert St. Nissing, Strassburger: Geschichte eines jüdischen Circus (Dormagen, 1993), 28; Hermann Arnold, Fahrendes Volk: Randgruppen des Zigeunervolkes (Landau/Pfalz, 1983), 178; this system of recruitment collapsed for various reasons in the 1930 s. 
audiences. ${ }^{33}$ Especially for those segments of the urban population that had only recently migrated to the bigger cities, the circus had a special appeal. The circus presented an idealized vision of nature, which was no longer a part of their daily experiences, but which continued to inform their memories and self-perceptions. The affinity of the rural population for the circus had a long tradition. For decades the horse shows did especially well in rural areas. As late as 1930, Das Programm, pointed out that: ${ }^{34}$

The rural spectator who views the horse shows is particularly in his element. He feels competent, and enthusiastically draws comparisons between his own horses and the well presented dressages. He declares, "this is real, not such a humbug like the Chinese or the traveling entertainer." That is the reason why circuses that present good horse shows will always leave the region of Eastern Prussia with a tidy profit. ${ }^{35}$

While some spectators enjoyed their first encounter with the sensual world of beauty and vitality in the circus, others took pride in their rural past as they watched the presentation of domestic animals. For them the circus provided a reminder of their origins, combined with an affirmation of the positive aspects of their new existence (free time and money to spend). The circus as a familiar form of entertainment and its rural show elements made them feel "at home."

"In the course of social migration and urbanization, these spectators financial resources considerably changed, both with regards to the income and to the priorities according to which such income was used within the contexts that were becoming increasingly diversified." Jones, Art and Entertainment, 13.

${ }^{34}$ This weekly newspaper for the professionals in mass entertainment such as circus, cabaret, and variety with the widest distribution was founded at the turn of the century and continued to publish until the Gleichschaltung by Nazi officials. Das Programm lost its importance as the voice of the unionized artists after 1933.

35 "Das Zirkusland Ostpreußen," in Das Programm, June 22, 1930, 28; documenta artistica collection in the Märkisches Museum Berlin. 
The circus did not merely reflect previous lives of the spectators or imitate their current situation. Circus performers questioned the myth of an idealized vision of nature and pastoral life as much as they reproduced it. The typical circus act tried to include familiar elements from its cultural environment, but often transformed and inverted these cultural elements. Familiar objects, costumes, music, animals, and even social relationships were combined in an unfamiliar way. What Paul Bouissac labeled cultural units, such as the "compatibility or incompatibility of certain situations and certain behavior ... were presented in an original and unpredictable fashion." ${ }^{36}$ Domestic and wild animals appeared as partners in one act, and categories of styles such as "the primitive" and "the historical" were mixed in unprecedented fashion. Animals that were "natural enemies" were presented together as when a tiger rode a horse. Other inversions were also calculated to achieve maximum effect, and animals outsmarted their trainers, as well as acrobats defeated natural laws of gravity.7

Like any other industry the entertainment industry was ruled by market forces. Moreover, differentiation into specialized sectors and an increasing concentration into larger units took place. At the turn of the century, a visible hierarchy and complex differentiation among the German circuses had emerged, and in this new situation the horse started to lose its unchallenged dominance. A growing number of circus shows began to present a greater variety of show elements including exotic animals, clowns, acrobatics and theatrical pantomimes. Thus, the late nineteenth century witnessed a successive differentiation into three main types of circuses: first, circuses that still centered their shows around horses (Pferdezirkus); second, those circuses that shifted their focus to presentations of predators such as tigers, lions, or bears of all kinds (Raubtierzirkus); $;^{38}$ and finally, those circuses that staged enormous

\footnotetext{
36 Bouissac, Circus and Culture, 7.

37 Ibid., 7.

38 "The newspapers, writing against the influence of "theater in circuses", stated that "today's circus needs as always needs great attractions, now that horse shows have become less
} 
productions of popular pantomimes (Theaterzirkus). The differentiation into the types mentioned above was not solely motivated by differing aesthetic senses among the individual circus director. These various types of circuses (Pferdezirkus, Raubtierzirkus, and Theaterzirkus) differed greatly in size, structure, and mobility of the enterprise, as well as in the social and ethnic background of the entrepreneur and his family. At the same time, the number of traveling circuses dropped considerably. Whereas 200 traveling circuses played in front of European audiences in 1900, only seventy remained in 1912. In Germany, forty-three circuses traveled in 1918 but only thirty in $1924 .^{39}$

Without exception, traveling circuses were family-run enterprises. Because they relied to a much greater degree than stationary circuses on animal acts most of them were Pferdezirkusse and Raubtierzirkusse. These acts were cheaper than the elaborate circus pantomime, demanded less staff, and relied to a great degree on individual skills. The familyoriented style of management was always calculated to minimize the cost of personnel. Family members trained animals, and acrobats were recruited out of the same pool. Family members held all leading positions in the organization and fulfilled multiple functions in the performances. Although traveling circuses seldom invested in unrelated skilled performers, one should not underestimate the costs of running a circus. Major expenses included those transportation, supplies, water, sanitary facilities, electricity, a heating system, taxes (especially the notorious "sin-tax" or Lustbarkeitssteuer), fees for the police, the building

popular, and it will not be difficult to find these. That is true for the big cities at least. What kind of artistic productions shall we regard as such attractions?.... First and foremost the display of predators. ...." Karl Döring, "Zirkus-Reform," in Das Programm, no. 1161, July 6, 1924, 8; documenta artistica collection in the Märkisches Museum Berlin.

39 Arnold, Fahrendes Volk, 165; see also G. Krause, Die Schönheit in der Zirkuskunst (Berlin, 1969). 
control department and the fire brigade as well as the ground rent, the costs of purchasing and maintaining of the menagerie, and the increasing costs for advertisement.

Few successful stationary circuses remained in Germany at the turn of the century. Of those that did, most specialized in the production of theatrical circus pantomimes (Theaterzirkusse). Unlike the traveling circuses, stationary arenas allowed for performances all year long, in summer as well as in winter, hosting up to 8,000 individuals at once. Their buildings could easily compete in their display of splendor and magnificence with the leading theaters of the time. Many of these permanent circuses were run by Gentile directors, who came from outside of the circus milieu. Hans Stosch-Sarrasani (Dresden), Paul Busch (Berlin), Hans Krone (Munich), or Carl and Wilhelm Hagenbeck (Hamburg) are the five most prominent representatives of such bourgeois entrepreneurs with managerial talents. ${ }^{40}$ They led their circuses in Berlin, Dresden, and Hamburg to the heights of popularity.

Although there were fewer stationary circuses than traveling ones, the former domineered the inner cities. Traveling circuses often played in the suburbs of the large cities, partly because variety and classical theaters feared the extraordinary competition of these circuses and partly because stationary circuses did everything to suppress such competition. Under the pretext of potential noise complaints municipal administrations supported the concerns of stationary circuses and made it very difficult for traveling circuses to gain access to inner city audiences. Stationary circuses, by contrast, were prominently located in the heart of the city centers. Circus Busch, for example, was located on the banks of the river Spree in

40 Hans Stosch-Sarrasani was born on April 2, 1873 and died on September 21, 1934 in Sao Paulo, Brasil. His Circus Sarransani was founded on April 4, 1901 in Radebeul near Dresden. His famous arena in Dresden opened in December 22, 1912. Carl Hagenbeck was born on June 10, 1844 in Hamburg and died on April 14, 1913 at the same location. Wilhelm Hagenbeck was born on November 3, 1884 in Hamburg and died on April 14, 1913. Carl Krone was born on October 21, 1870 in Osnabrück, he died on June 4, 1943. 
Berlin, right between the cathedral, the National Gallery, and the royal palace, and a stone's throw away from the stock exchange.

To fully grasp the widening gap between traveling and stationary circuses we shall tum to the circus entrepreneur who epitomized the stationary circus entertainment for several decades in Berlin: Paul Busch. Paul Vincenz Theodor Busch (1850-1927), founder of the Circus Busch, was the son of a wealthy wine dealer from Berlin and of a pastor's daughter from Lussow. His parents foresaw a church career for their son after the completion of his military service as a volunteer in the Prussian cavalry. ${ }^{+1}$ But together with his wife Constanze Sidonie Grabe (1851-1898), a famous trick rider of the time, Paul Busch instead founded a traveling circus with the financial support of his parental inheritance. ${ }^{42}$ The success of Constanze and her adult daughter Maria Dorée (1871-1901) as equestrian circus divas allowed the enterprise to expand quickly. On October 24, 1892, Busch opened up his circus arena in Berlin. ${ }^{43}$ At this time he already owned permanent circuses in Hamburg and Vienna, and soon after his opening in Berlin he also "conquered" Breslau.

Paul and Constanze Busch invested their entire resources in the production of elaborate circus pantomimes. The pantomime was, of course, not a new genre, but the size of these

41 The twenty year old Paul Busch served as a volunteer during the Franco-Prussian War in $1870 / 71$.

42 See Martin Schaaff, Die Buschens - 100 Jahre einer Circusdynastie (Berlin 1984), 8-9.

43 "The opening ceremony fascinated the capital! It was an exquisite demonstration of new almost unimaginable elegance and cultivated abundance, both because of the guests and the circus palace itself. A new era in Berlin's circus life began. The past was integrated into the present: The last circles framed artistic portraits of acrobats, clowns, circus riders, jockeys, and animal trainers, who -- once famous -- smiled towards the arena. Loud cheering welcomed the directors' couple and grew frenetic when Paul Busch greeted the people of Berlin, calling out: 'I was born in Berlin, I want to live and I want to die here!'" Schaaff, Die Buschens, 12-13. The aged director of the Circus-Busch-Archiv recalls the beauty of the circus building from his visits as a boy during the 1930s. 
shows in the Circus Busch was gigantic. With one of her early productions - Zscheus, das Waldmädchen"(1895) -- Constanze Busch created a spectacle that involved more than 440 individuals. Inspired by the discovery of a "wild child" (Wolfskind) -- an exotic Kaspar Hauser creature from the jungle; a story which occupied the international as well as the national press at the time -- Busch created a fantasy world populated by manly British officers, Indian gods, and exotic natives. A corps de ballet dressed as colorful butterflies, birds, and other foreign animals, swimming elephants, wild horses and moving pictures, overwhelmed an audience that for the most part had never left Berlin. Clearly, Constanze Busch was not only a talented performer; she also appealed to the Zeitgeist with her theatrical pantomimes.

After 1914, Paula Busch (1886-1973), the daughter of Paul and Constanze Busch, continued her mother's work. Whereas her mother was an autodidact, Paula Busch had enjoyed extensive schooling, including studies in philosophy and literature at various universities. She understood that the attention span of the audience was constantly decreasing, while its hunger for new sensations and novel means of stimulation was increasing. Paula Busch viewed the pantomime as a successful combination of tradition and progress, an adaptation to the accelerated rhythm of modernity:

Today's public wants to be offered more than just horses, clowns, and tightrope walkers, otherwise it will stay away. It enjoys the pantomime the most, because it unites all aspects of circus art, while presenting it in a way that bears only the faintest resemblance to the old shows. ${ }^{44}$

44 "Besinnungen auf Paula Busch. Von Oberregisseur Hans Krüger," in Das Programm, no. 8, 1952; Paula Busch became a queen of popular writing. Her books, articles in various newspapers, her plays, and pantomimes were read and seen all over Germany; as the only female directress of a circus in the Weimar Republic and the Third Reich, she was one of the most glamorous women of her time. 
The search for new attractions and new forms of entertainment within the realm of the stationary circus reflected economic necessities as much as a quest for new aesthetic appeal. The stationary circuses had to deal with one fundamental dilemma: acrobatic and animal acts required long years of training, but the local spectators demanded continually new sensations. Unlike the traveling circuses, which could leave sites once they had exhausted the curiosity of the local public, the stationary circuses such as Renz, Busch, or Sarrasani tried to compensate for the shortage of new acrobatic or animal acts with a display of new technical show elements. ${ }^{45}$ To bring variety to his show, Busch flooded the arena and staged so called water pantomimes. In 1891, the high point of one show was a water fountain twenty-five meters high, colorfully illuminated in the darkened arena. They also staged so-called Völkerschauen, the exhibition of "authentic" foreign tribes from far-away countries.

Although such technical wizardry and unfamiliar displays found wide resonance among the general public, the reaction of contemporary specialists was ambivalent. Leading artists organized in the union (Internationale Artisten Loge, I.A.L.) in particular complained that the skills of individual actors ceased to be the main focus of the circus. In their view, anonymous technological wizardry was replacing the artists' display of sensuality and vagabond romance. They chastised the stationary circus for having become a direct reflection of the mechanized lives of the spectators, and for having lost its capacity to transcend reality. These critics argued

${ }^{45}$ For reflection on the need for such constant innovation, see Wolfgang Jansen, Glanzrevuen der Zwanziger Jahre (Berlin, 1987), 19. "In this ever faster changing panorama, the owner of the big circuses were facing an increasingly demanding, and critical audience. They built huge circuses and decorated them luxuriously, surrounding them with stables for hundreds of horses, turning them into the vanguard of new technological possibilities and impossibilities. In the struggle for the audiences' favor, in the fierce duel with competitors, they tried to achieve the non plus ultra with the center-piece of their programs: with the circus pantomime." Busch, Spiel meines Lebens, 67. 
that the stationary circus was entangled in a process of increasing dehumanization - it was selling its soul. ${ }^{46}$

These criticisms reflect changes in the social structure of the circus as much as in the content of the circus shows. The stationary circus had become an enterprise with employers and employees. A gap between the director and the personnel had always existed, as a result of their differing social standing and in some cases their differing ethnic background. But in stationary circuses this gap was remarkably wider (and it was seen as such). Management and performers shared neither family bonds nor any deep-felt solidarity. Whereas family members accepted that their talents would be exploited for the good of the family and the good of the circus, unfamiliar circus performers in the stationary circuses were not satisfied with this arrangement. The concept of "das ganze Haus," which still applied to the traveling circuses, became anachronistic in the stationary circuses. ${ }^{47}$ In the stationary circuses, employers and employees were irreversibly polarized. The director's way of life remained hidden behind a curtain of bourgeois privacy, a barrier that was impenetrable for his employees because they

46 "Technology is the empress of our days. And the borders of her empire are still expanding. Romance, that fairy which once stood a the circus' cradle and to whom it [the circus] owed its sweetest gifts, concealed itself like a pale and silent woman in the ruins of the past, ostracized by rationality and prudence of this hasty present. Romance's empire is over and a different spirit rules the world." Karl Döring, "Zirkus Patomimen," in Das Programm, no. 433, 1910; documenta artistica collection in the Märkisches Museum Berlin.

47 This concept was first promoted by the German historian Otto Brunner in his influential article, "Das 'ganze Haus' und die alteuropäische 'Ökonomik'," in Otto Brunner, Neue Wege der Sozialgeschichte (Göttingen, 1956), 33-61; see recent reflections on the usefulness of the concept in Winifried Freitag, "Haushalt und Familie in traditionalen Gesellschaften. Konzepte, Probleme und Perspektiven der Forschung," in Geschichte und Gesellschaft 14 (1988), pp. 5-37; Claudia Opitz, "Neue Weg der Sozialgeschichte? ein kritischer Blick auf Otto Brunners Konzept des 'ganzen Hauses'," in Geschichte und 
did not live together any longer. Members of the I.A.L. were therefore much more critical of the management of the stationary circuses than of the traveling circuses. For them, the traveling circuses increasingly represented an ideal world of humanity and responsibility, whereas the stationary circuses were denounced for having broken the unwritten social contract of the circus world and for selling out to capitalism.

The directors of stationary circuses considered themselves to be integral parts of the urban elites in their respective cities and, as such, they participated in the ongoing construction and renegotiation of a cultural canon that was an integral part of upper middle-class norms and values. Arguably, these directors were the living proof that the boundaries between the worlds of bourgeois science and popular entertainment were much more fluid than is often assumed. The intellectual proximity of science and amusement was often mirrored by the spatial proximity of museums and concert halls on the one hand, and the Völkerschauen, circus, variety shows, show booths and street dealers on the other. ${ }^{48}$ In fact, circus directors prided themselves on having broadened the horizons of their public in a way no museum could do. They often downplayed the entertainment of these displays, and emphasized instead their educational value. Claiming to be motivated by higher goals, these directors insisted that their display of a foreign world could reach a greater audience and thus make a real contribution to the education of the masses.

To conclude, by the turn of the twentieth century the German circus had developed into a multi-faceted realm of popular entertainment. Most significant was the widening divide between stationary and the traveling circuses, both in terms of their aesthetics and their social structure. The differing ethos of the circus managements also mirrored the gulf between the

Gesellschaft 20 (1994), pp. 88-98, Hans Derk, "Über die Faszination des 'ganzen Hauses'," in Geschichte und Gesellschaft 22 (1996), pp. 221-242.

48 Quoted by Henning Berkfeld, ed., Hamburg in alten und neuen Reisebeschreibungen (Düsseldorf, 1990), 217-18. 
two types performance circuses. On the one hand, bourgeois entrepreneurs such as Paul Busch ran their circuses as capitalistic enterprises in accordance with the principles of profitability and public demand. They combined this business ethos with a conservative bourgeois world-view, balancing between merit and birth. On the other hand, traveling circuses retained a highly inclusive family structure. Solidarity was considered a moral obligation for both circus management and performers.

The circus integrated motifs drawn from past, present and future in a unique way. Traditional social and aesthetic elements were interwoven with modern elements in a manner that could not be compared to any other form of entertainment. New techniques of stage production, management, and transportation coexisted with highly codified performance rituals exalting an imaginary vagabond past. Gender stereotypes were reproduced as much as they were inverted. Images of nature were simultaneously idealized and questioned.99

Circus shows and their ambivalent messages were able to reach a far broader audience than did other cultural institutions such as theater, opera, or museum. Its combination of primitivism and refinement contributed to the circus's ability to appeal to all social groups. ${ }^{50}$ Nevertheless, despite the enthusiastic response of these spectators, the circus as a genre remained a social and cultural pariah, never achieving the cultural "legitimacy" bestowed on theaters or museums. Its deliberate commercialization of art and entertainment, as well as the inherent ambivalence of its performances, collided with bourgeois understandings of "good" art. The circus combined a variety of contradictory impulses that constituted pleasure. It was

\footnotetext{
49 Bouissac, Circus and Culture, 7.
}

so "The artist's skill is both primitive and refined. That is what guarantees the continuing passionate interest of both the lower and the upper classes." Max Nordau in Der Artist, no. 1206, March 12, 1908. 
this ambivalence that prevented its inclusion into the classical canon; but in return also led to its unique appeal to insiders and outsiders of society. ${ }^{51}$

51 Bouissac, Circus and Culture, 7. 


\section{Chapter 2 Circus Life}

"Unlike the actor, the artist is a man of being (Sein) and not of appearance (Schein). " 52 Victor Happrich

To what extent did German-Jewish circuses differ from Gentile circus enterprises in Germany? Until now historians have failed to explore the relationship between the social structure and practice of the circus on the one hand and its particular aesthetic on the other. Yet insights into the ethnic production and consumption of culture can only be gained through a close examination of the interdependence of these two components of mass entertainment. The case study of the German-Jewish circus family Blumenfeld provides a compelling focal point for such an analysis. The Blumenfelds represented a circus dynasty which by the turn of the twentieth century considered itself an integral part of an exclusive "circus nobility." This family ranked high in circus circles; its circuses figured among the ten leading circus enterprises of the German Empire. The history of this family is in many ways exemplary for the general history of German-Jewish circus enterprises. Insights into the microcosm of this family are thus of great relevance for the issue of ethnic cultural production and consumption in late nineteenth and early twentieth century Germany.

The ancestors of nineteenth-century German-Jewish circus families, who can be traced back as far as the Middle Ages, worked as magicians, jugglers, tight rope walkers, strong men and other acrobats. They traveled in large family units, accompanying Jewish doctors or peddlers. They entertained their clients with acrobatic stunts and sleights of hand on markets and at fairs. ${ }^{53}$ Most of these so-called Bankisten or Saltimbancos demonstrated their dexterity

s2 Der Artist no. 1206, March 12, 1908.

53 Medical doctors seemed to have been generally inclined to employ fairground entertainers to attract their audiences. Some of them performed themselves, amusing and curing their 
standing on an elevated wooden platform, a practice that explains their particular names. In addition to these performers who impressed their audience by their physical skills, others displayed wild or trained animals such as dancing dogs and bears, talking birds, or riding apes.

Fairground performers traditionally ranked low in German society. The disregard for the Fahrenden, as they were called, stemmed in part from the restless nature of their occupation. Their dubious social origins led to their exclusion from contemporary honor codes, and their open sensuality resulted in their rejection by the church. The status of the Fahrenden as de facto outlaws in German society did not change considerably until well into the nineteenth century. In 1846, a police commissioner (Ober-Polizei-Commisär) in Gotha warned other police officials about these traveling artists, insisting that one could hardly distinguish these performers from Gypsies, especially since they conversed in the same underworld slang. ${ }^{54}$ The police official claimed not to be able to distinguish between traveling performers and thieves. His description includes one of the few references to the language of these traveling entertainers. For him, the distinct language was the strongest indication of their marginality. Their social isolation, due to their constant migration, found its most visible expression in their use of a distinct dialect, a phenomenon common among migrating groups at the time. This testimony confirms contemporary attitudes toward traveling artists as socially marginal. A specific language served as an ethnic marker indicating an ethnic boundary, a criterion by which membership in the social group was determined.

Jewish performers were the most likely to appear visibly distinct from the rest of the population. The language of pre-emancipation Jews tended to attract the particular attention of their Gentile environment. In fact, for many contemporary Gentiles, Yiddish was identical with

patients. In 1733 the chronicle of Memmingen, for example, took note of a popular doctor, traveling with 30 musicians, acrobats, dwarfs and dancers. Günter Bose and Erich Brinkmann, Circus. Geschichte und Ästhetik einer niederen Kunst (Berlin, 1978), 24.

Arnold, Fahrendes Volk, 172. 
the language of the thieves - a view which can be traced back as far as the Renaissance.

Scholars argued that contemporary Germans "saw in the language of the Jews the language of the most marginal elements of European society - beggars, thieves, and wandering murderers. ${ }^{.55}$ In all likelihood, the group of traveling performers to which the police official referred in his note was in fact made up of traveling Jewish entertainers, conspicuous because of both their occupation and their ethnic origins. An analysis of the specific composition of their language provides important information not only about the ethnic but also about the regional origins of these families.

The so-called Blumenfeldsprache -- a mixture of French, Yiddish, Romance (Gypsy dialect) and the technical jargon of the circus -- is one variation of these circulating dialects. This dialect was exceptionally popular among German-Jewish fairground entertainers and stemmed from one of the most prominent of these Jewish families of artists. In 1811 , the Blumenfelds were the first Jewish family to found an independent circus enterprise. ${ }^{56}$ Beginning in the seventeenth century, we find the name Blumenfeld in multiple city chronicles, in connection with acrobats as well as tightrope dancers. ${ }^{57}$ But it was not until two families of

55 Sander Gilman, Jewish Self-Hatred. Antisemitism and the Hidden Language of the Jews (Baltimore and London, 1986), 68.

56 At this point the Circus Blumenfeld consisted of four horses, two bears, several dogs and apes, as well as the acrobats of both families.

57 According to records of the archivist Ernst Geller, one can trace the name Blumenfeld in chronicles of Frankfurt and Leipzig to the seventeenth century. See file "Blumenfeld" in the Circus, Varieté- und Artistenarchiv, Marburg. See also Signor Saltarino, Das Artistentum und seine Geschichte (Leipzig, 1910), 26; Signor Saltarino was the pen-name of the circus historian Hermann Waldemar Otto. He published in contemporary professional journals such as Das Programm, Der Artist, and Das Organ. He also authored two highly influential reference books: Signor Saltarino, Artisten-Lexikon. Biographische Notizen über Kunstreiter, Dompteure, Gymnastiker, Clowns, Akrobaten... aller Länder und Zeiten (Leipzig, 1895), reprinted in Roland Weise, Bibliotheca artistica. Die bunte Welt vom 
fairground performers were joined through marriage in the early nineteenth century that the first traveling German-Jewish circus was founded. These were the French-Alsatian family of Maurice Levi Cerf (1783-1867), ${ }^{58}$ which traveled with a menagerie of birds or apes, and the German family Blumenfeld from the Rhineland, which presented acrobatic and strong-man acts. The first family introduced the French element into the Blumenfeldsprache, whereas all of them were fluent in Yiddish. ${ }^{59}$ Both families originated in rural regions with traditional Jewish communities. ${ }^{60}$ In addition to their similar occupation and mobility they shared common beliefs and values. This might have facilitated the collaboration of the families in all spheres of their daily lives, including communal meals and religious practices.

Like other German-Jewish families of fairground performers, the Blumenfelds perceived marriage as a way to realize their dream of material success. The marriage of Maurice Levi Cerf to a daughter of the head of the Blumenfeld family was certainly encouraged by strategic motives, as was demonstrated by the groom's decision to adopt the bride's last name

Varieté, Zirkus und Schaustellerwesen, vol. I (Leipzig, 1987) and the above named Das Artistentum. Hermann Waldemar Otto was born on April 14, 1863 in Hohenstein/Erzgebirge and died in January 11, 1941 in Düsseldorf. See for information on Otto: Ulrich, Daten, 10, 3.

58 Touring Germany, he called himself Moritz Hirsch. In 1867, he died in Darmstadt at the age of eighty-five. An authenticated copy of the death certificate can be found in the "Blumenfeld" file in the Circus, Varieté- und Artistenarchiv Marburg.

59 France had developed into the heartland of the circus in the early nineteenth century. The technical jargon of the circus, therefore, was mainly French. This constituted another reason the French element within the Blumenfeldsprache did not fade away, regardless of the successive "Germanization" of this circus family.

60 Alsatian Jews in the countryside preserved their Judeo-Alsatian dialect throughout the nineteenth century, despite the considerable effort of the educated elites within the urban Jewish communities to introduce French as the common language. Paula Hyman, The Emancipation of the Jews of Alsace. Acculturation and Tradition in the Nineteenth Century (New Haven and London, 1991), 65. 
and become Moritz Blumenfeld. Although this was an unusual step for a man at the time, it was calculated as a means to acquire a family name that carried considerable weight in the world of popular entertainment. ${ }^{61}$ The strong bonds of rural Alsatian Jews to German-Yiddish culture might have eased this decision for Cerf: and the inevitable "Germanization" of his family probably posed less of a threat for him than it might have for a Parisian Jew.

By the second half of the nineteenth century, the Circus Blumenfeld had established itself as a medium-sized circus enterprise in Central Europe. Emanuel Blumenfeld (18111885), the third son of Moritz Blumenfeld, inherited the circus in 1834. In July 1854, following his father's example, he married Jeanette Stein (1831-1896), the daughter of a another circus director. ${ }^{62}$ This marriage led to the second fusion of two family enterprises within two successive generations, and it provided the material foundation for this remarkable rise of a family of fairground entertainers to large-scale circus entrepreneurs.

A partnership between artistic families was by no means an exceptional phenomenon, as collaboration was commonplace among traveling artists. They intended to profited from each other's skills and expertise in order to increase their own attractiveness on the market. Unlike most partnerships of this kind, which lasted hardly longer than one season or two, Jewish families attempted to consolidate alliances. Marriage was one of the most effective means to

61 The marriage is reported to have taken place at Beuel near Bonn. The special permission of the community was needed to legalize this unusual name change. See the "Blumenfeld" file in the Circus, Varieté- und Artistenarchiv Marburg.

62 Emanuel Blumenfeld was born on March 1, 1811. See Ulrich, Daten, 7. Jeannette Stein was born in Landau, Bavaria. This was Emanuel Blumenfeld's second marriage after the death of his first wife Jette Hadoch, who in turn was born in Cussfeld. See Willi Janeck, "Erinnerungen an den Circus Blumenfeld," in Deutsche Circus-Zeitung, February 1957, 15. References to the early history of the Blumenfeld circus also found in "Circus E, Blumenfeld Wwe.," in Der Artist, no. 1500, November 9, 1913, Theaterhistorische Sammlung Unruh, FU Berlin. 
this end. Arranged marriages were not infrequent, based on considerations of social and ethnic compatibility and a family's combined desire to conserve or increase capital, on the one hand, and to acquire new skills and material on the other.

Over four generations, the majority of the male and female members of the Blumenfeld family married into the German-Jewish circus families of Strassburger, Könyöt, and Goldkette. ${ }^{63}$ These seemingly anachronistic, highly inclusive ties account for the survival of these circuses.$^{64}$ At times of crisis and economic hardship, the Blumenfeld and the Strassburger families demonstrated a solidarity that went far beyond what one might expect from potential competitors in the strained market of mass entertainment. ${ }^{65}$ When the FrancoPrussian War endangered the existence of the previously prospering Circus Blumenfeld in 1871 -- because of the conscription of the adult sons and the closure of traditional travel routes -- these two families temporarily joined together in 1871 in order to be able to present a competitive program to their audiences. ${ }^{66}$ These two German-Jewish families thus managed

63 The related Könyöt family formed a famous riding ensemble from Hungary. They performed equestrian stunts, that included seven male and female trick riders on one horse. Their progenitor was Leopold Kohn, a Jewish-Hungarian businessman. The Goldkette family derived from an ancient line of traveling performers, who had presented their skills and tricks at the coronation of Maria Theresa. They altered their name in the course of the twentieth century, and four of them formed the world-famous artistic group, The Four Bronnetts.

64 For further information on the Strassburger family, see the recent publication of Nissing, Strassburger. Unfortunately, this study is largely descriptive.

65 The collaboration was not confined to the Strassburger family alone. In 1875 , for example, the son of Mayer Blumenfeld, a brother of Emanuel Blumenfeld, founded his own circus enterprise together with Francois Goldkette. See Saltarino, Das Artistentum, 26-29.

66 On the economic difficulties of the Blumenfeld family, see "Circus E. Blumenfeld Wwe.," in Der Artist, no. 1500, Nov. 9, 1913, in the Theaterhistorische Sammlung Unruh, FU Berlin. 
not only to survive the war, but also to realize a renaissance of their former glory. ${ }^{67}$ Although this temporary union was a particularly spectacular example of the collaboration of GermanJewish families, it was by no means exceptional in nature. Even in prosperous times, the two circuses often worked together. The Circus Strassburger staged guest performances at the various winter domiciles of the Blumenfeld circus in Guhrau and Magdeburg, and frequently stopped off in Magdeburg before continuing its annual tour. ${ }^{68}$

A marked clannishness was the rule within the circus milieu in general. At first glance, Gentile and Jewish circus families seem to have been equally exclusive. No circus family, Gentile or Jewish, could afford to lose a member through marriage to an outsider. Such decisions could potentially endanger the very existence of the remaining family members, and individuals were expected to give way to the communal good. This rational, however, does not explain the cleavages that ran through the circus milieu itself. German-Jewish families not only distanced themselves from the surrounding majority society, but also from Gentile families within the circus milieu. Neither in the nineteenth nor in the twentieth century can one find German-Jewish circus directors without previous affiliation with the circus. All GermanJewish circuses started off as traveling circuses and this close-knit group demonstrated a clear distaste for outsiders. They interacted with the Gentile circus families in a professional way, but they did not share their private lives. Whereas the ethnic boundaries that were accepted by these circus families allowed for and even welcomed interactions on the level of the "market," they seemed to limit any relationship that might undermine commitment to the ethnic group.

67 In 1874, Emanuel Blumenfeld employed 35 women and men permanently and displayed 40 expensive horses. Willi Janeck, "Erinnerungen an Circus Blumenfeld," in Deutsche CircusZeitung, February 1957, 15. Das Programm, no. 1082, 11; documenta artistica collection in the Märkisches Museum Berlin. 
Family genealogies reveal that from the early nineteenth until the early twentieth centuries, marriage patterns among German-Jewish circus families mirrored those of the German-Jewish economic élite. ${ }^{69}$ In both cases, one commonly finds marriages between close relatives, such as an uncle to his niece or, between cousins of various grades. Multiple marriages between families also occurred frequently, with pairs of brothers marrying pairs of sisters. ${ }^{70}$ Although the established German-Jewish business families would certainly have refused to see any similarity between themselves and the German-Jewish circus families, the marriage strategies of both German-Jewish groups followed the traditional marriage pattern of pre-emancipation German Jewry. The persistence of seemingly anachronistic social patterns of inclusion allowed the German-Jewish circus families to fight off economic hardship successfully. These specific social patterns constitute a key to their successes in the late nineteenth century.

The travel schedules of German-Jewish circus families were commonly divided into a highly mobile travel season and an immobile winter season. Historians and sociologists have paid considerable attention to traveling circus performers. Little regard has been paid to their regular periods of immobility during the winter months, however. These five months from November to March were meant to provide rest and recreation during the winter, since unpredictable weather made traveling with animals and large quantities of equipment impossible. But they also offered an opportunity to put new stunts together, to train the

69 Ernst Geller, the director of the Circus, Varieté- und Artistenarchiv Marburg, has drawn up various family trees from German-Jewish families. His findings were completed by family documents. In the case of the Blumenfeld, family Ms. Gabriela Blumenfeld from Magdeburg was particularly helpful. She contributed previously unknown family material to the archival collection in Marburg.

70 Werner E. Mosse, The German-Jewish Economic Élite 1820-1935. A Socio-Cultural Profile (Oxford, 1989), 164. 
animals, and to carry out the necessary repairs of the material. The winter season se altered the inner life of the circus as well as its social relations with the public.

The seasonal "homes" in the Winterquartier allowed for a more intensive exchange between the migrant circus people and the world around them. In fact, circus families, who hardly had any informal contact with the majority culture during their travel season, did have the chance to seek contacts outside their milieu during the winter period. Most circuses returned to the same location every year. ${ }^{71}$ They generally owned the facilities to which they returned. Usually, all artists accompanied the director's family; only the seasonal workers returned to their respective homes in the villages of Bohemia and the Palatinate. During the winter season, the circus families lived in regular homes instead of the traditional travel wagons; thus their neighbors were not necessarily colleagues or family members. Their children attended the local schools; they had time to shop for their individual households; and they frequented bars or restaurants. Hence the insulated nature of the traveling circus was at least structurally suspended during these winter months.

The relationship of the German-Jewish circus Circus E. Blumenfeld Wwe. with the outside world is reflected in the sources on their jubilee celebration on the hundredth anniversary of the existence of the circus. A close reading of this special event sheds light on the status of the circus family within the social fabric of a small town - in this case, the

71 The diligence with which the circus Blumenfeld adhered to this seasonal pattern inclined the contemporary "Signor Saltarino" to label the directors of the Circus Blumenfeld the most "settled" circus directors of the time ("die 'seßhaftesten' Zirkusdirektoren Deutschlands"). "Seßhaft" has a double connotation in this context, which goes beyond the factual meaning of residency and implies a respectability which can only be provided by membership to a local community. This double meaning suggests an exceptionally successful self-promotion of German-Jewish circus families: They seem to have become widely known for outstanding integrity and conservatism, which in return was their best publicity. 
Silesian town of Guhrau, situated about eighty kilometers northwest of Breslau. ${ }^{72}$ In 1911 , the Blumenfeld family styled this jubilee celebration as a symbol of its unbroken predominance as a leading dynasty in German circus entertainment. The festivities involved virtually the entire city. Local notables hurried to pay their respects to the directors Hermann, Simon, and Alexander Blumenfeld. ${ }^{73}$ More than 300 congratulatory messages from all over Europe reached the press office of the circus. The municipal orchestra provided a festive atmosphere during the formal reception of the mayor and the deputies of the City Council at the house of the eldest brother Simon. Since the private houses of the circus directors were unable to accommodate the hundred invited guests, the gala dinner had to be held in the palatial room of the town hall. ${ }^{7+}$

The mayor and main speaker, Mr. Götz, emphasized the importance of the circus for the town's life. According to Götz, the people of Guhrau always referred to the Blumenfeld circus as "our circus," a choice of words that was, in his eyes, a clear sign that the townspeople identified strongly with the circus. Götz continued by stressing the economic contributions of the circus to the business community of Guhrau. "An enterprise that makes a

72 After the death of Emanuel Blumenfeld, his widow Jeanette Blumenfeld assumed control of the enterprise. The Circus Emanuel Blumenfeld Wwe. bought the former military barracks in Guhrau, and designed it as the new winter domicile of the enterprise in 1885. Its most important industry was textiles (Tuchmacherei). Hugo Weczerka, ed., Schlesien. Handbuch der historischen Stätten (Stuttgart, 1977), 169-171.

73 They were the sons of Emanuel and Jeanette Blumenfeld. Simon was born on January 29, 1861 and died in December 1942 in the concentration camp Theresienstadt; he was married to Rosa Strassburger (who died in 1944 at the concentration camp Theresienstadt as well.) Rosa and Simon Blumenfeld had eleven children: Therese, Willy, Betty, Jeanette, Alfred, Alex, Alfons, Arthur, Eugen, Erich, Fritz, Alice; of these children, only Arthur survived the Third Reich, only to commit suicide in 1951. Simon's brother Adolf died on Janurary 14, 1913 the other brother Hermann died on March 17, 1933. See the file "Blumenfeld" in the Circus, Varieté und Artistenarchiv Marburg. 
profit of several thousand Marks annually, and which employs an army of countless locals to work," he stresses, "has an immense importance for the community."75

In 1911, the traveling circus Blumenfeld reached the zenith of its fame. Its directors could proudly reflect on a century of continuous social advancement. Each generation had been able to profit from the achievements of the previous one. The family seemed to have catapulted itself from the periphery of society right into the heart of a local community, whose honorary members, half a century earlier, would have refused to accept them in their midst. The marginalized fairground performers of the late eighteenth century had developed into bourgeois entrepreneurs. The central act of this celebration, the handing-over of several donations by the circus management to a variety of communal institutions, was clearly motivated by the desire to make a statement of their acceptance among wide circles of the town's population and a demonstration of civic pride. The Blumenfeld directors not only donated 7500 Marks for the construction of a public pool, and the interest of 1000 Marks to Protestant and Catholic welfare institutions, but also decided that the interest generated by a further 1000 Marks should be given out annually to the destitute, in the honor of Emanuel Blumenfeld, the founder of the circus. $^{76}$

The Blumenfeld's activities reflected the traditional structures of self-help within Jewish-orthodox communities. Beginning in 1885 , the Blumenfeld family, as one of the wealthiest families in town, saw it as its particular duty to engage in the social life of the

74 "Die 100 Jährige Jubelfeier des Zirkus E. Blumenfeld Wwe.," in Das Programm, no.406, 1911; documenta artistica collection in the Märkisches Museum Berlin.

${ }^{75}$ Das Programm, no. 406, 1911; documenta artistica collection in the Märkisches Museum Berlin.

76 Das Programm, no.406, 1911; documenta artistica collection in the Märkisches Museum Berlin. 
community. ${ }^{77}$ They not only owned a circus enterprise, but possessed a large amount of property in the surrounding area. ${ }^{78}$ By the first decade of the twentieth century the Blumenfelds had built up a special reputation for their charitable endeavors -- a reputation that resonated among a wider public. ${ }^{79}$ Gentile directors of stationary circuses such as Sarrasani or Busch concentrated their donations mainly on police, military, local administration, and other institutions which could further their enterprises. In contrast, the German-Jewish Blumenfeld gave money to local welfare services, schools, and hospitals, without regard to their denominational affiliation. Whereas the Gentile management of stationary circuses sought to gain entry into the exclusive bourgeois circles of their local communities, German-Jewish circuses aimed primarily at gaining a popular presence among the middle classes of their winter quarters (Winterquartiere). Whereas the Gentile stationary circus attracted its audiences by the glamour of its performances alone, the German-Jewish circus management was also deeply concerned to defend or enhance its moral reputation.

The specific approach of German-Jewish circus management could easily be interpreted as an attempt to fend off potential antisemitic resentment among the local population. This

77 "They belong to the wealthiest burghers of the district, paying the highest taxes. Apart from the massive arena, the stables etc., each of the three brothers owns a house in Guhrau. In addition, Hermann also owns a villa and several houses on the island of Norderney. Adolf, who spends his winters in Berlin -- where he calls extensive property his own -- has recently reentered the circus enterprise in the function of a manager." Das Programm, no 464,1911 , documenta artistica collection in the Märkisches Museum Berlin.

78 "During the summer they travel with an impressive tent and an excellent troupe. In the late fall they return to their winter quarters in Guhrau, Silesia, where they own large estates." Saltarino, Das Artistentum, 28.

79 "And just as the respectable name Blumenfeld attracts masses of spectators in all regions of Germany, the sympathetic directors are known for their charity in their Heimat. They are loved and admired by masses and elites. Director Hermann Blumenfeld for example, is frequently offered honorary offices of all kinds." Saltarino, Das Artistentum, 28-29. 
interpretation would, however, disregard Jewish traditions such as charity for the poor and sick members of the religious community. These traditions were considered to be religious obligations, moral commandments, and focal points of the Jewish faith. ${ }^{80}$ In the postemancipation period, the Blumenfelds seem to have extended traditional patterns of caretaking beyond the boundaries of the Jewish community and applied them to the entire local community. On the local level of Guhrau, they saw the need for new projects and began to expand the type of aid they offered, without altering the nature of their charity. They did not search for a more organizational approach to make a contribution to communal life, but continued to seek occasions for fund-raising events, through which they aimed to support a variety of charitable ventures and continued granting individual aid and comfort to the destitute. Most noteworthy of all, unlike the traditional forms of Jewish welfare, which insisted on anonymity in order to avoid humiliating the recipients of charity, German-Jewish circus families had no interest in keeping their actions secret. On the contrary: publicity was part of their business.

It would be mistaken to see these activities as solely public relations gestures and as such as unequivocally "modern." Many German-Jewish circus families observed Jewish laws and rituals, at least to the extend that their mobility allowed them to do so. Even one of the three Blumenfeld directors, Hermann Blumenfeld, ${ }^{81}$ son of Emanuel and Jeanette Blumenfeld,

80 Elisabeth Kraus, "Jüdische Stiftungstätigkeit: Das Beispiel der Familie Mosse in Berlin," in Zeitschrift für Geschichtswissenschaft 45, no. 2 (1997), 104; see also Georg Heuberger, ed., Zedaka: Jüdische Sozialarbeit im Wandel der Zeit (Frankfurt a. M., 1992); Andreas Reinke, Judentum und Wohlfahrtspflege: Das jüdische Krankenhaus in Breslau 1744-1944 (Hanover, 1998); Rainer Liedtke, Jewish Welfare in Hamburg and Manchester, 1850-1914 (Oxford, 1998).

81 Hermann Blumenfeld was married to his niece Betty Blumenfeld, who was the daughter of his brother Simon Blumenfeld. Hermann Blumenfeld died on August 17, 1933. 
became famous among the Gentile and the Jewish circles of the circus milieu as the "ideal type" of a pious Jew, a conscientious circus patriarch and a devoted son:

Hermann, who never misses mass [sic!], who writes a touching epitaph to his beloved mother, is also the greatest horse expert in the stables, as well as the best technician for the construction of the tent, an experienced connoisseur and authority in all areas of the business. ${ }^{82}$

The practice and application of charitable functions within the local community of their Winterquartier reflects their self-confident religiosity as much as it may have been a reaction to social pressures such as antisemitism or calls for cultural assimilation. The social ethic of Judaism paid great attention to social dimensions of life ${ }^{83}$ The philanthropic activities of the Blumenfelds were thus by no means a rejection of, or alienation from, their Jewish identity, but rather an expression of its confident embrace. In fact, for these German Jews, "philanthropic activity did not merely affirm Jewish identity, but actually defined it." ${ }^{84}$

The jubilee celebration of the German-Jewish circus family Blumenfeld in Guhrau, a city of artisans and small shop-keepers, also reveals the ambivalent status of the GermanJewish circus enterprise. Municipal elites stressed the economic contributions of the circus enterprise to communal life, but failed even to mention the content or quality of the performances. In addition, the laudatio of city officials tended to obscure the inherently restless nature of the circus enterprise. The circus family Blumenfeld was not honored as a family of artists by the municipal delegation, but rather as an important employer in the local economy. Any artistic evaluation of the circus was limited to the present members of the artistic press and

82 Kober, 17.

${ }^{83}$ Elisabeth Kraus, "Jüdische Stiftungstätigkeit," 121.

84 Derek Penslar, "Philanthrophy, the "Social Question" and Jewish Identity in Imperial Germany," in Leo Baeck Institute Yearbook 38 (1993), 58. 
representatives of the artistic union (I.A.L.). ${ }^{85}$ Perhaps most telling of all, the donations by the circus directors were publicly appreciated as the donations of wealthy entrepreneurs, but not as expressions of traditional Jewish philanthropy.

The circus, however, did not fail to leave its mark on the social fabric of the town. Although residency during the winter months did not lead to the development of strong personal bonds between the circus people and the local population, and the close-knit social structure of the circus was maintained, even though winter living conditions would have allowed other behavior, members of the circus entertained amicable professional relationships with the towns people. While the ethnic background and the professional occupation of the Blumenfeld family were visible to the entire population, these factors did not hinder or harm professional relationships in the pre-war period. Respect and appreciation were not necessarily motivated by private intimacy. The structural separateness of the German-Jewish circus families converged with their presence in local affairs.

Whereas intimate relations with the town's population were limited, similar boundaries and reservations were clearly absent among the circus people themselves. For them residency in the winter quarters had important emotional and social functions. In contrast to their audience's assumptions, the circus personnel did not have much time for romantic entanglements or intimacy during their months on the road. The emotional bonds necessary to endure the demanding life of the circus, especially within the family, were therefore established and nursed during the Winterquartier period. Permanent residency between November and March cemented business and family relationships, allowing performers to recover from stress and exhaustion, and facilitated the family's preparations for the coming season.

85 "Die 100jährige Jubelfeier des Zirkus E. Blumenfeld Wwe," in Das Programm, no. 406, 1911, documenta artistica collection in the Märkisches Museum Berlin. 
Given the restorative functions of this seasonal period, it is important to note that German-Jewish families shared this period of intimacy and privacy with each other. Their children played together and conducted the necessary training in the same arenas. These steady contacts assured the continuation of strong emotional ties among German-Jewish circus families from one generation to the next. ${ }^{86}$ For example, after 1885 , the large Blumenfeld family invited the Strassburgers to share their winter accommodation in Guhrau; they continued to do so after their move to Magdeburg in the first decade of the twentieth century. Salomon Strassburger, the founding father of the Strassburger dynasty, was even buried at Guhrau. ${ }^{87}$ Like the German-Jewish middle class, who exchanged visits and celebrated traditional holidays together, these circus families adjusted their emotional and social needs to their calendar of life. $^{88}$

Family members of German-Jewish circuses distinguished themselves from other members of circuses not only in their marriage patterns and their relative social isolation, but also through the size of their families. Unlike the German-Jewish population at large, German-

86 As late as 1925, Das Programm pointed to the centrality of the Winterquartier. Again the Blumenfeld and the Strassburger families seemed to be paradigmatic: "Every traveling circus has its winter quarters. They represent the calming influence in the continuing flight ["ruhenden Pol in der Erscheinung Flucht"]. They are the source of strength for the activities in the summer, they are also experimental sites at which in dedicated work everything is created that amuses and educates thousands of people in the summer time. The city of Magdeburg, especially, has become a real circus city after the brothers Blumenfeld have put up their main quarters. Not only the Blumenfeld, but also the circus Strassburger spend the winter season there,..." in Das Programm, March 8, 1925, 7; documenta artistica collection in the Märkisches Museum Berlin. "Salomon and Amalie Strassburger had seven children together.... All of them remain true to the circus and married into the old circus families Kossmeyer and Blumenfeld." Nissing, Strassburger, 16.

87 Nissing, Strassburger, 16. 
Jewish circus families had not altered their reproduction patterns by the second half of the nineteenth century. The birth rate of these families revealed all the characteristics of the traditional pre-emancipatory family structure of German Jewry. Like other German-Jewish circus families such as the Strassburger and the Lorch family, the Blumenfelds had numerous children. Moritz Levi Blumenfeld had seven children. Emanuel and Jeanette Blumenfeld had to provide for a family of sixteen children, four of whom stemmed from Emanuel's first marriage with Jette Hadoch. Each of their sons and daughters had between eight and eleven children. Clearly, the fertility rate of the Blumenfeld family, exceeded the fertility rate of either the Gentile or the Jewish non-circus population. ${ }^{89}$ In the first decades of the nineteenth century the proportion of births to marriages per year was 4.3 for society at large and 5.2 for German Jews. By the 1870 s this relation had changed, Jewish families had 4.3 children while the equivalent rate for society at large was still 4.6. At the turn of the century the relation between birth and marriage among the Jewish population was 2.8 , compared to 4.4 among the Gentile population per year. ${ }^{90}$ In contrast to the general trend among German Jews to decrease their number of children - even before the Gentile population followed their example -- GermanJewish circus entertainers lived in traditionally large family units until the twentieth century. They did so, moreover, in apparent disregard of fundamental changes in their social status, a growing sense of security, relative affluence, and increasing concentration in the cities.

A closer analysis of the life and needs of a Jewish circus family reveals how different its demographics was from that of the Jewish community at large. Demographic historians

88 See Marion A. Kaplan, The Making of the Jewish Middle Class. Women, Family and Identity in Imperial Germany (New York and Oxford, 1991).

89 All of these families were either German-Jewish, or Alsatian-Jewish circus families with independent, medium sized circus enterprises.

90 Shulamit Volkov, Jüdisches Leben und Antisemitismus im 19. und 20. Jahrhundert (Munich, 1990), 140. 
have often argued that modern city life necessarily inhibited high fertility. In the modern city, the argument goes, children were more costly and contributed less to production than they did in the countryside: in the cities, John Knobel insists, "secular values prevailed, social mobility rose, and women found employment away from home." ${ }^{191}$ The declining fertility rate of German Jews, the most urbanized minority in Germany, preceded that of the general population by a generation or more. The Jews' eagerness to reduce the number of children per family has often been attributed to their willingness to assimilate to the German Gentile bourgeoisie. ${ }^{92}$ Their attempts were paralleled by a growing alertness to bourgeois tastes and sensibilities. For the majority of German Jews, Bildung (self-formation) not only functioned as a key to molding the individual personality, but more importantly as an entry ticket to bourgeois society. Education was costly, and since many Jewish families were known to have provided higher education for both their sons and their daughters, most German-Jewish families could not afford to support numerous children. ${ }^{93}$

Within the circus, formal Bildung did not have the same importance for the promotion of Jewish performers as it did for most German Jews. The necessary instruction of the offspring of German-Jewish circus families was provided within and by the family for girls and boys alike. The children in the circuses were apprentices of their parents or older siblings. Traditional learning was handed down from generation to generation. Usually, "apprenticeship" for most children began at the age of four or five. The graceful appearance of

91 John E. Knodel, The Decline of Fertility in Germany, 1871-1939 (Princeton, New Jersey, 1974), 89.

92 "Menschen mit einer starken Motivation sich zu assimilieren, entschieden sich, die Größe ihrer Familien zu reduzieren, indem sie der 'Qualität' anstelle der 'Quantität' den Vorzug gaben, Volkov, Jüdisches Leben, 142.

93 Among many see Shulamit Volkov, "Erfolgreiche Assimilation oder Erfolg und Assimilation. Die deutsch-jüdische Familie im Kaiserreich," in Wissenschaftskolleg zu Berlin, Jahrbuch 1982/83 (Berlin, 1984), 374-387. 
a light-footed acrobat was the result of hard and disciplined training over a period of many years. A childhood in the circus milieu supplied the necessary stimulation, challenge and instruction for a successful career as a circus performer.

Unlike traditional Jewish families, circus families did not differentiate between the training of their sons and daughters. The general lack of formal training in terms of Bildung might have facilitated the relative gender balance in the circus. Both sons and daughters were considered valuable members to the family enterprise and were treated equally. Whereas in the pre-emancipation Jewish community, the obligation to educate children, primarily sons, rested upon the father, the training of German-Jewish circus children was taken up by the mother and the father. ${ }^{94}$ Although the traditional family structure seemed to lead to a power imbalance between men and women within the family, their more equal work resulted in something close to de facto equality in the daily life of the circus. The absence at a division of work in family life contributed to this factual equality.

Against this background, it is appropriate to reappraise the equation historians have drawn between high fertility and a lack of formal Bildung on the one hand, and a low degree of assimilation on the other. Unfortunately, current concepts of acculturation and assimilation have focused to a great extent on the relatively small and homogeneous German-Jewish educated élite. No one has adequately demonstrated that these concepts are applicable to German Jewry at large. That larger body was characterized by a much greater heterogeneity than the Jewish educated middle class, not only in occupation, mobility, and religious beliefs, but also in family structure and social practice.

The theoretical contexts within which ethnicity has been studied have emphasized either ethnic pluralism or ethnic assimilation. According to these interpretations, ethnic groups persist

94 On educational patterns in traditional Jewish families, see Paula E. Hyman, Gender and Assimilation in Modern Jewish History (Seattle and London, 1995), 47. 
as separate entities, or they change in character and become less distinct from "mainstream" society.. ${ }^{95}$ The example of the Blumenfelds in Guhrau demonstrates, however, that sharing many similarities with the majority society did not preclude the preservation of the Blumenfeld family's structural separateness. This separateness included the maintenance of a distinctive language, which provided German-Jewish circus families with a sense of bonding. Marriage patterns and fertility rates, key social practices of the German-Jewish circus families, constituted further elements of this voluntary distinctiveness. Lastly, these families' separate identities were intensified in exclusive friendships, intimacy and in such idioms as the ritualized invocation of the names of the founding fathers.

German-Jewish circus families in the nineteenth century cultivated a life-style that did not necessarily betray an essential ethnic marker in content, but whose particular social practices set them apart from other circus families. This separateness was an expression of their mobility, their occupation, and their social, ethnic, and regional origins. It did not result, however, from a lack of contact with, or information about German society at large. Rather, such separateness actually depended on an exchange with the majority culture and the exploitation of specific niches in the market of mass entertainment. Because German-Jewish circus families actively set themselves apart in a process of ascription and self-identification, their resultant separateness was due more to their own behavior than to exclusion by the Gentile circus milieu. ${ }^{96}$ For the German-Jewish circuses, these specific social practices

95 Frances E. Kobrin and Calvin Goldschneider, The Ethnic Factor in Family Structure and Mobility (Cambridge, MA, 1978), 1.

96 In an influential essay, Frederik Barth was the first to point out that ethnic boundaries were not due to the isolation of the particular group, but that groups were in fact in continuous contact with one another. Thus the persistent fact of cultural variation remains to be accounted for. Fredrik Barth, "Introduction," in idem., ed., Ethnic Groups and Boundaries. The Social Organization of Culture Difference (Bergen, 1969), pp. 9-38; more recently see 
represented the key to material success, which allowed them to establish themselves permanently in the realm of German circus entertainment. Ironically, then, it was their "preemancipatory" traditionalism that enabled these families to succeed in and even dominate the entertainment market. Among the five leading traveling circuses in pre-war Germany, three were run by German-Jewish families. These families' apparent lack of assimilation was in itself a highly successful adaptation to the demands of turn-of-the-century mass entertainment.

Thomas Hylland Eriksen, Ethnicity and Nationalism. Anthropological Perspectives (London, 1993), ch. 3. 


\section{Chapter 3 Artists and Audiences}

The Blumenfelds, as a typical German-Jewish circus family, desired to be a model of middle class respectability and ingenuity, pitting themselves against other less noble figures in the circus milieu. They envisioned their public image as three-dimensional, combining the identities of honorable business men, romantic artists, and upright artisans. The Blumenfelds conceived of these different images as compatible, although they had not been so in the past. In the Middle Ages, for example, in times of artisanal production, publicity and advertising were unnecessary. According to the honor codes of the traditional guilds, these forms of selfpromotion were not considered respectable. Only marginalized groups of society, such as fairground performers or Jews, who were not granted membership in these guilds, were allowed to advertise their art and skills. ${ }^{97}$ The images of the upright artisan and the Jewish artist were by definition mutually exclusive, as was the image of the Jewish businessman and the artisan. Hence, in the self-perception and self-promotion of German-Jewish circus families, brought together competing concepts which had been historically incompatible. The appropriation of an artisanal honor code belied their own past as outlawed German-Jewish fairground performers. The significant effort that German-Jewish circus families such as the Blumenfelds took to fashion tradition and custom in their favor, reinventing their professional identities, constituted an attempt to gain a respectable past after they had established themselves in the present. As members of the German middle classes, they were aware that their future lay in their past.

97 Karl Heinz Feuerstein, "Vom Ankündigungsplakat zum Schaustellerplakat," in CarlAlbrecht Haenlein and Wolfgang Till, ed., Menschen, Tiere, Sensationen, Zirkusplakate 1880-1930, May 5 to June 18, 1978, exhibition catalogue Hannover, 18, also W. Danckert, Unehrliche Leute. Die verfehmten Berufe (Bern and Munich, 1963). 
It is hardly surprising that bourgeois virtues constituted the common links between the three identities: artisan, artist, and businessman. Each of these images drew their legitimization from an appreciation of individual merit and an idealization of hard work and discipline. A high respect for honesty was another common element binding together all three facets of this selfperception. This honesty was itself put very much put "on show." The traditional circus ring heightened the physical reality of the acts, for no curtains and double bottoms deceived the public's eye. The Marxist philosopher Ernst Bloch in 1959 pointed to the irony that the leastrespected form of cultural entertainment could serve as a paradigm of the highest moral and aesthetic codes. He acknowledged the aspirations of classical circus entertainment and combined his analysis with the claim that the inherently bourgeois honesty of circus entertainment was exemplary of art's highest ideal..$^{98}$

Circus directors such as the Blumenfelds also aimed to attract spectators by the quality, craft, precision and honesty of their performances. The Blumenfelds' goal was to attract and hold an audience of middle-class regulars. Gerda Blumenfeld, the wife of the circus director Alfred Blumenfeld, recalled that in their endeavor to make a name for themselves, their seasonal tours habitually included the same locations in their travel routes. ${ }^{99}$ The circus management hoped that this might establish a crowd of regular customers in various cities and thus minimize their economic risk. Because these regulars were mainly recruited from the middle classes, the program and self-promotion of the circuses catered to both the normative and aesthetic expectations of these social circles, and their fears. By 1909, the rejection of foreign competition by the German middle classes had increased. Economic competition was

98 Ernst Bloch, Das Prinzip Hoffnung, in idem, Gesamtausgabe, vol. 5 (Frankfurt a. M., 1959), 422-23.

99 Gerda Blumenfeld memories, original manuscript in the posession of her grand daughter Gabriele Blumenfeld in Magdeburg. See also Der Artist, no. 1500, November 9, 1913; Theaterhistorische Sammlung Unruh FU Berlin. 
not only aggravated within the national borders but also through the import of foreign products. In order to stress their traditional work ethic and their local patriotism, the directors of the Blumenfeld circus emphasized that they resisted the growing "Americanization" of circus entertainment.

Historians have examined the immense impact of American cultural and economic influences on the Weimar Republic. These studies rightly point to the heated public debates in the mid-1920s about America's influence on the German economy, and they illustrate German's ambivalent reactions to America (as they understood it): its "advanced technology and unprecedented economic prosperity, its high wages and brisk work pace, its dizzying consumption patterns and emergent mass culture, its new women and disturbing family life." ${ }^{100}$ Far less research has been done on American influences in the Imperial period, however, although many stereotypes existed prior to the First World War. ${ }^{101}$ Mass entertainment was one of the first social spheres to deal with the challenges from across the ocean. Since historians have failed to identify the circus as the first mass medium, they have consequently focused on the Weimar period, viewing film as the first and primary vehicle of Americanization. ${ }^{102}$

100 Mary Nolan, "Imagining America, Modernizing Germany," in Thomas W. Kniesche and Stephen Brockmann, ed., Dancing on the Volcano. Essays on the Culture of the Weimar Republic (Camden House, 1996), 71. For a more extensive account of rationalization and Americanization, see Mary Nolan, Visions of Modernity. American Business and Modernization of Germany (Oxford, 1994).

101 Nolan, "Imagining America," 78.

102 For a recent account of the American influences on German film, see Thomas J. Saunders, Hollywood in Berlin. American Cinema and Weimar Germany (Berkeley, CA, 1994). Unfortunately Saunders does not provide a detailed analysis of actual films, but focuses instead on the discourses about film in Weimar Germany. 
Beginning with the introduction of the chapiteau, American innovations in the professionalization of technology and management played an important role in circus entertainment. The debates about "Americanization" were not only debates about speed and efficiency, generally subsumed under the notion of rationalization. They also included the questions of mass consumption and the consequent standardization of consumer goods. German circus circles also harbored ambivalent feelings about American influences on German popular culture. In particular, German-Jewish circus enterprises stressed that their public demanded quality instead of quantity. As in every other sphere of consumption, German tastes in mass entertainment changed slowly. Tradition continued to figure as the best guarantor of quality, whereas anonymous mass production was still looked down upon by the German middle classes. According to this rationale, mass production and sensationalism went hand in hand. To find the right tone at the right time was a skill in which Germans and German-Jewish circus directors prided themselves:

We do not practice advertising as it is imported from America, i.e., postings of lithographs in showcases, because among a thousand posters shown to the audience, not a hundred of them reflect reality. Our advertisements will only present what we really do offer. Along with other solid, sound enterprises, we are combating the excessive American advertisements that have become so popular in the past years, and we will announce our shows accordingly in proper fashion. ${ }^{103}$

Aside from securing their market, Jewish circus entrepreneurs were eager to engage in a dialogue with their audiences, to share similar values. Their goal was to establish a rapport that, as Jewish entertainers, they could not take for granted. Fearing the stigma of the "tasteless parvenu," the Blumenfelds wanted to separate themselves from the countless newcomers who

${ }^{103}$ Published in 1909 in a newspaper, this assessment is cited by Rudolf Geller, "Die Familie Blumenfeld und ihre Circusse," in Die Zirkuszeitung, Kulturhistorische Gesellschaft für Circus und Varietékunst e.V., June 1992, 23; Circus, Varieté- und Artistenarchiv Marburg. 
flooded the market. Just like any other middle-class business, they drew attention to their longterm presence in the market. Their demonstrative abhorrence of the new methods of selfpromotion - such as catchy flyers, colorful posters or sensational journal articles -- revealed as much about their own outlook and German-Jewish identity as it reflected their audiences's sensibilities. One of the most pervasive antisemitic stereotypes of the nineteenth century conflated Jews and "parvenus." "Manchesterism" and ruthless modernization were often equated with "Jewish" greed and capitalism by small businessmen, shopkeepers and artisans. ${ }^{104}$ Because these groups constituted a large portion of the audience of the Blumenfeld circuses, any form of sensationalism was carefully avoided by most German-Jewish circuses. Even when equipment or financial practices had to modernized, the necessary changes were carried out hidden from the spectators.

Despite their public disclaimers, the circus management was not opposed to Amerikanisierung as a means to make their enterprises more efficient and profitable. The Circus E. Blumenfeld Wwe. was the first traveling circus to switch their transportation of men and material from horse and cart to special trains - a move that prompted contemporaries to describe them as the ideal type of a German traveling circus. ${ }^{105}$ By 1900 , the Blumenfeld circus managed to visit 120 cities in one season and twenty-four locations in one month. This was all the more remarkable in that the circus traveled at this time with six tents in addition to the chapiteau, 28 wagons, 130 horses, a huge collection of electrical equipment, and its own

104 See Shulamit Volkov, The Rise of Popular Antimodernism in Germany. Urban Artisan Masters, 1873-1896 (Princeton, NJ, 1978).

105 "During this time the Circus Blumenfeld Wwe. developed into the most typical German traveling circus [Typus deutscher Wandercircusse]." in Der Artist, no. 1500, November 6, 1913; Theaterhistorische Sammlung Unruh FU Berlin. In 1925, the Blumenfeld family had already owned a stationary circus for five years; yet they were still counted among the traveling circuses. Das Programm, April 26, 1925; documenta artistica collection in the Märkisches Museum Berlin 
string orchestra. ${ }^{106}$ The heavy reliance on train transportation could easily be considered as an expression of exactly the kind of Americanization the Blumenfelds fiercely rejected in their public announcements. But this specific form of "Americanization" -- the use of new technology -- did not carry a stigma, because it aligned itself with a popular belief in technical and social progress. Catchy advertisements, by contrast, were closely associated with cheating or fraud. ${ }^{107}$ Behind the battle against "unfair competition" (unlauterer Wettbewerb) a battle fought in the name of "good manners" (guten Sitten) one could sense the resentment of traditional small workshop holders against the extreme market orientation and commercial acumen (such as publicity, sales, etc.) of big business. ${ }^{108}$

The directors of the different branch-circuses -- there were always several Blumenfeld circuses traveling at the same time - were particularly eager to demonstrate their popularity among the local nobility when they arrived at a new location. ${ }^{109}$ In 1896 , the circus management even trumpeted its good relations with these elites on their official letterheads, promoting themselves as "Circus E. Blumenfeld Wwe., Europe's largest traveling circus, 80

106 "Even before Barum and Bailey toured Europe with their gigantic enterprise, the Circus E. Blumenfeld Wwe. already operated, although on a smaller scale, nevertheless at a similar speed as the Barum system. E. Blumenfeld Wwe. was able to accomplish what no other German circus could before." in Der Artist, no. 1500, November 9, 1913;

Theaterhistorische Sammlung Unruh FU Berlin. On the size of the circus, see Willi Janeck, "Erinnerungen an Circus Blumenfeld," in Deutsche Circus-Zeitung, February 1957, 15.

107 The high mobility of the Blumenfeld circuses could only be achieved through a long term commitment from their well-trained personnel. Contemporary sources confirm that there must have been a particularly agreeable working atmosphere within the Blumenfeld circuses.

108 Jürgen Kocka, Klassengesellschaft im Krieg 1914-1918 (Göttingen, 1973), 69.

109 See for example the presence of the Prince of Corevey at the guest performance of the Blumenfeld circus in Ratibor, Das Programm, no. 589, 1913; documenta artistica collection in the Märkisches Museum Berlin. 
horses, 28 caravans. Distinguished by the visits of royal personages." ${ }^{110}$ Frequently, the circus management organized charity performances to demonstrate their good relations with the old elites and to consolidate their self-definition as respectable members of the middle classes. In March 1910, for example, the Blumenfelds managed to collaborate with the Prussian military in hosting a fundraising performance at which Kaiser Wilhlem II and the crown prince were present. ${ }^{111}$ In this respect the attitude of the Blumenfeld family differed quite considerably from those of the stationary circus directors such as the Gentile entrepreneur Paul Busch. Paula Busch recalls that her father usually reacted quite negatively when he was asked to collaborate in a charity performance sponsored by the old elites. He knew that he would not gain from such co-operation; instead these charity events represented an unwelcome interruption of his enterprise. ${ }^{\mathrm{I} 2}$ Jewish circus managers, however, wanted to ensure that their loyalty to crown and fatherland and their respect for social hierarchy were left in no doubt. The following passage, published in Das Programm in 1911, illustrates the particular nature of the relationship between the nobility and the circus:

Distinguished guests at the Circus E. Blumenfeld Wwe. On the 11th of this month, his Royal Highness the Grand Duke and the Grand Duchess of Mecklenburg-

110 Landeshauptarchiv Sachsen-Anhalt, Rep. C 29, Tit. IV, 13, Nr. 15, Bd. II, 320.

11 Das Programm, no. 413, 1910; documenta artistica collection in the Märkisches Museum Berlin.

112 "One day the privy councilor [Paul Busch] urgently asked Miss. stud. Phil. Paula to come and see him. The Hofmarschallamt had called. The crown princess asked whether I [Paula Busch] would join a group of other young ladies of society to perform at a charity festivity. A circus prank was particularly desired.... "Sawade may give you his most dangerous tiger, who should then devour you on stage! That would be a funny prank for the people!" This caustic joke demonstrated my father's great distaste for those charity events that were so popular among the contemporary high class. He had a different concept of welfare and of measures to do away with poverty and distress. Paul Busch had no patience for the fostering of public relations in society." Busch, Spiel meines Lebens, 133. 
Schwerin honored a performance of the Circus E. Blumenfeld Wwe. at Schwerin with their presence. The Highnesses stayed throughout the entire program; the following day at 3:30 in the afternoon, the sovereign couple returned to the circus, this time to pay full respect to the Blumenfeld brothers, and to visit the stables. The Blumenfeld brothers guided this half-hour tour. During this time, the sovereigns affably conversed with the Blumenfeld brothers who will never forget the day on which they were honored by these German princes. Finally the sovereigns departed, not without a handshake. (We congratulate the directors Blumenfeld on these illustrious visitors, who serve to demonstrate our previous claim that persons of highest rank show a lively interest in variety theaters and circuses. The editors.). ${ }^{113}$

The general tone of this report is a mixture of devotion and pride. German-Jewish circus directors imagined and styled themselves as subjects of a benevolent ruler, whose graceful appearances set them apart from other circuses and provided them with an aura of "being chosen." The apparent informal and private setting in which the Blumenfelds were asked to parade their horses was meant to highlight mutual respect and appreciation between the circus directors on the one hand and the noble elites on the other. Indeed, the frequent appearance of the German nobility at circus performances was greeted with great satisfaction among circus circles. These visits were immediately posted in professional journals and local daily newspapers to impress the public and to enhance the social status of the circus. They also lent clout to circus enterprises in their battle with state officials to be regarded as cultural institutions equal to the great theaters of the time. One important benefit that derived from such respect was the exemption from the notorious sin-tax (Lustbarkeitssteuer). Whereas "higher artistic" (künstlerisch hochstehende) cultural institutions were forced to pay between 3.5 to 8 percent of

${ }^{113}$ Usually, these kinds of notices were sent by the circus direction to the editorial staff of the respective journals, which in most cases did not change the wording. The Blumenfeld circus's press officer probably was responsible for the article; Das Programm, no. 476, 1911; documenta artistica collection in the Märkisches Museum Berlin. 
their daily income, circuses in comparisons were required to pay 25 percent of their income to the state. ${ }^{114}$

The relationship of German-Jewish circus families to state authorities was shaped less by modern nationalism than by premodern patriotism (Landespatriotismus). The frequent emphasis of the circus management on the popularity of the circus among the German nobility was an important maneuver meant to overcome the conflict between the circus as an international institution and the growing nationalism of its audiences. Circuses were not limited by national boundaries, but toured all over Europe. Some even incorporated South America and Russia into their travel routes. They hired international artists and their employees spoke numerous languages and practiced different religions. Modern nationalism which was based on the notion of a Kulturnation, a prominent expression of which was a shared language, thus posed a threat to the circus management, for it could potentially endanger the existence of the circus as a cultural institution.

In this context, traveling circuses needed to put much more effort into proving their loyalty in times of crisis than did stationary circuses. Although traveling circuses spent considerable time outside the German nation-state, their audiences still wanted them to "feel most German." I5 Thus, by reverting to the already "outdated" concept of Landespatriotismus, German Jewish circus directors tried to avoid shipwreck on the shoals of national sentiment. They imagined themselves as a part of a community of subjects that defined itself through personal allegiance to the Emperor, instead of a community whose membership was based on race, religion, language, or territory. In short, the managers of traveling circuses resorted to a demonstrative conservatism (Wertkonservatismus) in an era of national awakening.

\footnotetext{
114 See "Die kulturelle Bedeutung des Zirkus," in Das Programm, no. 1342, 1927, 13. 115 Roger Chickering, We Men Who Feel Most German: A Cultural Study of the Pan-German League, 1894-1914 (Boston, 1984).
} 
The concept of a benign relationship between a ruler and his subjects was an idealization of pre-emancipatory times. Because members of the German-Jewish community had been denied citizenship and civil rights in Germany until 1869, they had been particularly dependent on a good relationship with the crown and its representatives. Only the king could protect them from the mistreatment by local authorities. The Blumenfeld directors saw in their personal contact with high-ranking nobles a public acknowledgment of mutual respect. A symbiotic relationship existed, but the relationship had changed significantly since preemancipatory times. German-Jewish entertainers no longer performed at the court. At the turn of the century, the artist was not only hoffähig, but he had found his own realm of sovereignty: in the circus, he welcomed the nobility to join him.

The self-promotion of the Blumenfeld family demonstrated the self-confidence of these circus directors, stressing the parallels between the German Empire and the "circus empire." In 1924, after the demise of the German and Austrian monarchies, Das Programm compared the all-powerful position of the director to that of an enlightened despot within the "circus empire." Das Programm praised the Blumenfeld family for its exercise of personal power and sovereignty, promoting the communal good. The following passage suggests that because mistakes had been made in the realm of high politics, it fell to circus directors to communicate order and authority to the masses. Once again, the Blumenfeld circus was presented by the professional press as a circus enterprise able to set an example that radiated beyond the boundaries of mass entertainment:

As far as the position of the director within the enterprise is concerned, there is no well-being without authority. Just as it is impossible it is to claim hegemony in politics and government without exercising authority -- Austria, for example, collapsed after the hegemony of Habsburg came to an end - one can not do without authority in the realm of the circus. There has to be authority. But authority should not degenerate into tyranny. Violence is always a symptom of weakness, as is terror.... A good patriarchal relationship between directors and artists, demonstrated just recently 
at the birthday of the director Alfons Blumenfeld, or as one can also see at the CorthyAlthoff circus - a relationship which has not degenerated into awkward familiarity on the one hand, and which does not diminish the rights of the artists on the other - is and will be the best and most beautiful [sort of relationship]. ${ }^{116}$

The wish of the circus directors to be considered the friends of tradition and authority was reciprocated by many (though not all) members of the upper and upper-middle classes. The nobility appreciated the Pferdezirkus as a form of entertainment that propagated their norms and values to a wide audience. In this sense, the circus represented an important vehicle for the communication and legitimization of noble conceptions of chivalry, militarism and glamour. These characteristics did not necessarily conform to middle-class tastes and sensibilities; nevertheless, they had already in the nineteenth century entered the cultural canon of the middle classes via cultural institutions such as the circus. Thus, concepts and world-views that were originally identified with the nobility were appropriated by the wider public and, to a significant degree, ceased to be exclusive. The Blumenfelds cultivated public exchange with traditional elites because this relationship was the most visible expression of the transcendence of their past. The circus as a realm with unique social and aesthetic possibilities provided a welcome forum for this transcendence.

${ }^{116}$ Karl Döring, "Zirkus Reform," in Das Programm, no. 1168, August 24, 1924, in the documenta artistica collection in the Märkisches Museum Berlin. 


\section{Chapter 4 "Puppchen, Du bist mein Augenstern!" -- Aesthetics and the Challenges of War}

In the summer of 1914, rapidly unfolding political events took the Circus E. Blumenfeld Wwe. by surprise. The regular visit to Posnan suddenly ceased in the middle of the season. Within days, seven sons of the family were called to arms. The chapiteau and most of the horses were expropriated for army use. The remaining stragglers from this once-prospering circus enterprise barely made it back to their home base. This moment seemed to mark the tragic death of a Jewish circus enterprise that could look back on a history of more than one hundred years of circus entertainment. Indeed, when the Blumenfeld family temporarily went "off the ring," it was more than doubtful whether they would ever be able to return.

After the war, hyperinflation and constrained mobility, as a result of the regulations of the Treaty of Versailles were so severe that the existence of many German circuses, Gentile and Jewish alike, hung by a thread. Circuses which in the pre-war period had rarely run into visa problems crossing the borders of Central Europe were suddenly constrained within the smaller post-war German territory. The impoverished German population was hardly able to provide a reliable audience for the numerous circuses. The heavy losses of personnel and equipment were equally catastrophic for these enterprises, and increasing competition of variety shows and moving pictures further endangered the market for circus entertainment.

The various Blumenfeld circuses, overcoming the initial shock, reorganized and continued to perform in their largest Winterquartier in Magdeburg. Yet these circuses could not maintain the high standard of their performances: their staff was drastically reduced, and their animals had either starved to death or had been recruited for front use. The war years brought extreme hardship for the Blumenfeld family, which was certainly not exceptional for these 
times -- many of the smaller circus enterprises had to give up their businesses entirely. Both Gentile and Jewish circus enterprises were challenged by these changes. Jewish circuses, however, were hit particularly severely by the post-war crisis. This massive crisis among Jewish circuses cannot simply be explained by the overall economic hardship. Only a closer examination of the aesthetics of their performances in the context of trends within German mass entertainment at large, can explain these developments.

To understand the demise of Jewish circus enterprises during the First World War and its aftermath, one has to gain an understanding of what motivated them to subscribe to very specific aesthetic elements in the pre-war period. As soon as they had been able to afford horses, equestrian acts had dominated the show of German-Jewish circuses and continued to do so until well into the twentieth century. The three greatest German-Jewish circus enterprises were particularly acclaimed for their free-ranging dressage, displaying up to one hundred stallions in one show. Hohe Schule and Jockeyreiten were integral parts of their horse shows. ${ }^{117}$ Both show elements suggested socially exclusive values such as quality and prosperity. Until 1914, the enthusiasm for horse shows was so high that the dancing operetta horse "Puppchen," rather than a human artist, became the greatest celebrity on display in the Blumenfeld circus. ${ }^{118}$ The operetta horse "Puppchen" was always announced individually in

117 "For every long-stemming circus friend the name Blumenfeld is unforgettable. Especially in Germany, this name was known among horse lovers for over a century. The equestrian shows of the Blumenfeld, especially the tournaments were always a special treat for the eye." Willi Janeck, "Erinnerungen an Circus Blumenfeld," in Deutsche Circus-Zeitung, February 1957, 14.

118 "Puppchen" was named after a famous song by the composer Jean Gilbert, alias Max Winterfeld whose song and operetta "Puppchen" was one of the most successful operettas in Berlin's history. Jean Gilbert's multi-faceted career exemplified, how popular entertainment genres were interconnected, exchanging motifs, styles and performers. Jean Gilbert had conducted the orchestra of the Circus Hagenbeck, and later became a staple at 
the programs. A pas de deux with a prima ballerina was the high point of its acts, in which "Puppchen" masterfully demonstrated its ability to perform numerous dance steps. The horse was able to change rhythms without any apparent help by its trainer. In the pas de deux, the graceful appearance of the ballerina was matched by the elegance of the horse. By choosing the horse to perform the "male part" in the act, the unwritten laws of compatibility were altered in a fascinating way. Two of the most popular elements of the circus aesthetic - the fragile ballet dancer and the vigorous horse -- were combined to form an ensemble that thrilled audiences. In previous circus performances, the ballerina had danced on the horse, but now she danced with the horse; the two were equal partners in an "unnatural" act that suggested a sexual inversion of its own concept. These performances carefully refrained from being openly erotic; but the unwritten script carried traces of the "beauty and the beast" concept. Puppchen became human to a degree unknown in previous circus history. Puppchen's sudden death from colic was mourned by many spectators. The circus directors staged its cremation like a state funeral, accompanied by the participation and sympathy of the masses.

Whereas stationary circuses such as the Circus Busch introduced circus pantomimes into their shows, the Blumenfelds created a different aesthetic with their widely acclaimed mock tournaments (Ritterspiele). These circus acts recalling the exploits of medieval knights were in fact responses to heated contemporary debates about social status and honor in Imperial society. The tournaments evoked elements of the court societies of the Middle Ages, which had already been mimicked by the riding societies in the early period of the circus. The individual agility and riding skills of the acrobats, captured by a ritualized combat situation, imitated the dueling tradition of the nobility. Of course these displays were themselves artificial, so art was imitating art. Having become popular in the twelfth century in Germany, tournaments had

the exclusive Metropol Theater, the leading popular revue and operetta theater of Berlin. Otto Schneidereit, Berlin wie es weint und lacht. Spaziergänge durch Berlins 
quickly ceased to have a purely military function and developed into a means of self-portrayal for noble knights. These duels were meant to demonstrate superior virtues such as courage, loyalty, and self-control. Serious injuries were neither intended nor necessary to bestow honor and social distinction. ${ }^{119}$ The toumaments were acts of friendship and peace in which combatants treated each other with respect. ${ }^{120}$ The appropriation of these honor codes by the circus performers popularized these norms and values and combined them with an educational purpose, rendering them even more entertaining (and less lethal) than the original tournaments. Thus circuses totally ignored contemporary dueling practices of the German Empire, which were decidedly more lethal than duels fought in other countries. ${ }^{121}$ These circus acts promoted values such as liberty, self-determination and manliness, but not the compulsive nature of many duels in military and academic circles. ${ }^{122}$

Imperial Germany's military and the universities had developed elaborate codes of conduct for the satisfaction of honor. These codes rested on the exclusion of certain minorities who were denied the ability to render "satisfaction" (Satisfaktionsfähigkeit). ${ }^{123}$ Most prominent

Operettengeschichte (Berlin, 1973), 161-62, 165.

119 Ute Frevert, Ehrenmänner: Das Duell in der bürgerlichen Gesellschaft (Munich, 1991), 21. 120 Ibid., 22.

121 Both Kevin McAleer and Ute Frevert agree on this point, although their studies differ greatly in interpretation. Frevert claims that the bourgeoisie appropriated a formerly noble honor code and made it their own, whereas McAleer argues that dueling was one of the means by which the German bourgeoisie attempted to imitate their betters. Frevert, Ehrenmänner; Kevin McAleer, The Cult of Honor in fin-de-Siècle Germany (Princeton, 1994).

122 Frevert, Ehrenmänner, 235.

123 See Norbert Kampe, Studenten und "Judenfrage" im Deutschen Kaierreich (Göttingen, 1988). For the concept of antisemtism as cultural code: Shulamit Volkov, "Antisemitism as Cultural Code: Reflections on the History and the Historiography of Antisemitism in Imperial Germany," Leo Baeck Institute Year Book 23 (1978), 25-46. 
among such excluded minorities were the Jews. Jewish circus directors, however, refused to accept this discrimination. With their mock medieval tournaments, Jewish circuses asserted both their own and their audiences's inclusion in a traditional honor code. During the Middle Ages, the common people, and among them the German Jews, had been equally excluded from these tournaments. But now popular entertainment could make good a historical deficit. The tournament as a circus act was taken out of its traditional social context and ceased to be the privilege of one particular group in society. As the following passage suggests, these acts conveyed the message of social peace and friendly competition, not vicious antagonism and mortal combat. Most importantly, they were addressed to all factions of society, not one particular group:

The achievements of this circus in other areas are outstanding as well; its performances in the arena prove this best. These are not pantomimes, but novelties that co-director Mr. H. Blumenfeld himself created, and which the press acknowledged as particular specialties. The Hannoversche Anzeiger and the Casseler Tageblatt even accredited the tournaments [Ritterspiele] at the Zirkus E. Blumenfeld Wwe. with a higher educational value. ${ }^{124}$

Whereas stationary circuses used ever more spectacular modern technology to stage their gigantic spectacles, often allowing set and scenery to overpower the individual actor, German-Jewish traveling circuses still perceived the artist as the central element of their shows. They turned to the roots of circus entertainment to gain new inspiration. German-Jewish circuses attempted to meet the growing demand for a theatrical choreography of the individual acts, without, however, losing the equestrian element as the central component of their shows. Thus the Blumenfelds continued to present "quality over quantity," refusing to fall victim to Americanization. Their adherence to such middle-class norms as individual merit and skills, a

\footnotetext{
124 "Zirkus E. Blumenfeld Wwe. (Guhrau)," in Das Programm, no. 500, 1911, documenta artistica collection in the Märkisches Museum Berlin.
} 
sense of history, self-formation and civic pride gained the Blumenfeld circus the respect of middle-class newspapers. In 1920, a local newspaper discussed the performance of the traveling Blumenfeld circus in Cologne. A study of the newspaper report demonstrates that although they were well-received, the Blumenfeld shows were quite atypical for the time. By the 1920s, the Blumenfeld circuses had become the circuses of the "good old times": that is circuses in danger of losing touch with the new trends in mass entertainment. In other words, at the moment these circuses gained entry into the bourgeois cultural canon, they were already in danger of losing their broad-based appeal. The Circus Blumenfeld

does not attempt to be fashionable by simultaneously putting up two or three rings, whose respective acts would compete with additional stunts in the air, and who consequently push to the limit the audiences' capacity to observe and absorb. [....] A magical act and a comical scene in which the beginning of Schiller's "Räuber" was performed were the highlights of the clown's act,.... It has to be acknowledged that this circus cares for its horses and the dressage lovingly; it is thereby attempting in an exemplary manner to conserve the original nature of the circus as a cultural and educational institution [Zirkus als Kultur- und volksbildenden Faktors]. ${ }^{125}$

The traditional horse shows, with their naive evocation of an ideal world, their endorsement of a pseudo-military honor-code, and their appropriation of a noble aesthetic, suddenly appeared anachronistic and inadequate after the First World War. Because of the changed aesthetic desires of fluctuating audiences, German-Jewish circuses were under increasing pressure to alter their programs. ${ }^{126}$ The increasing impoverishment of their pre-war middle-class clientele

125 "Blumenfeld" file in the documenta artistica collection in the Märkisches Museum Berlin. 126 Contemporary circus specialists like the journalist de Kloot (Das Programm) mourned these changes, but simultaneously accepted that they were irrevocable. "Shortly after the war the majority of circus lovers ceased to appreciate the highest challenge of rider and horse [he is referring to Hohe Schule]. One may conclude that the critical audience for such distinguished shows seemed to be missing." M. de Kloot, "Glück auf den Weg," in Das 
exacerbated the economic troubles of German-Jewish circuses after the First World War, especially because they were unwilling to attract spectators with catchy announcements of sensational spectacles, relying instead on the survival of their immaculate reputation among a regular clientele.

Studies of class formation and social mobility during the First World War have demonstrated that the lower middle-classes were especially hard hit by the economic crises between 1916 and 1924. German-Jewish circuses lost an important section of their audiences due to the catastrophic consequences of the war. The savings of the audience melted away in the inflation. Shopkeepers and artisans were hard-pressed to make a living because the purchasing power of their clientele dropped dramatically. The economic situation of whitecollar workers was similarly catastrophic, and their salaries hardly covered their essential needs. Immediately after the outbreak of the war, their salaries dropped between $25 \%$ and $50 \% .{ }^{127}$ Their losses were greater than those of the working classes. Between 1916-1918, despite bonus payments and limited salary increases, the income of white-collar workers remained far below the subsistence level and the income of industrial workers. ${ }^{28}$ Thus, while the potential audience for circus entertainment was more and more recruited from the working classes Jewish entrepreneurs did not target this social group specifically. Indeed, Jewish circus families did not conceive their enterprises as entertainment solely for the working classes, even though this social strata of society had and increasingly did consume mass entertainment.

Although Blumenfeld circus directors had been attentive to changes in the audiences's taste before 1914, during the war they failed to react to these alarming signs of popular disenchantment. The third generation of German-Jewish circus directors held on to their central

Programm, no. 1624, May 24, 1933, documenta artistica collection in the Märkisches Museum Berlin.

127 Jürgen Kocka, Klassengesellschaft im Krieg 1914-1918 (Göttingen, 1973), 71. 128 Ibid., 71. 
horse acts because they continued to perceive the horse as an integral component of their ethnic identity. The horse had symbolized three different social factions: the landowners, the nobility, and the military, all of which had been closed to German Jews in pre-emancipatory times. That past was still recalled from accounts of their fathers generation, for most members of the third generation were born before 1869 . They grew up as the first generation to enjoy legal equality, guaranteed by their German citizenship. This generation was reluctant to displace the horse, because it represented their emancipatory successes. The horse was a potent symbol of their personal pride and achievements.

In many ways the horse was a central cultural symbol of Imperial Germany itself, capturing the many facets of German society. It was a familiar sight on the streets, harnessed in front of street cars and beer-lorries or as a means of social distinction for the upper circles of society. Most Germans acknowledged the value and importance of the horse. Hence the determination of the third generation of German Jewish circus directors in holding on to equestrian acts, disregarding their lack of profitability, indicates that they perceived these acts as part of their dialogue with German society at large. Members of this generation saw themselves as full citizens of the Second Empire and embraced its social order without, however, accepting its limitations and deficiencies in respect to Jewish emancipation. Within their own "circus empire" they corrected these "faults" of society at large and displayed an ideal world of chivalry, honor, and courage to their spectators. This vision, in turn captured and informed the dreams and aspiration of the masses until the eve of the First World War.

The opening program for the season in 1920 in Dessau indicates that horses continued to dominate the program of the Blumenfeld circus:

Wander-Zirkus Gebr. Blumenfeld Jun. Magdeburg, formerly E. Blumenfeld Wwe. Guhrau (1811-1920) 
Program

1.-3. Music, Conductor: Mr. Hubrich

4. Der Rosenkavalier, four gentlemen riding on two horses each

5. Humorous escapades by two comedians

6. Miss Victoria, riding bare back

7. Pia Coco-Trio, The Mysterious Melody and other pieces

8. Nero and Pluto, Breeding bulls exquisitely trained to perform by Director Arthur Blumenfeld and Mr. Enriko.

9. Alfonso Castello and Company -- Catapult acrobats ( 6 persons)

10. Pascal and Ervero Spanish foot jugglers

10-minute intermission

11. Music -- screening of commercials; new ads will be accepted any time in the main office.

12. Triumphant wagon procession set in Nero's time

13. Gadbin Brons -- guest appearance only.

14. Free dressage by Miss Amalie Lorch and Director Alfons Blumenfeld; includes eight Pintos trained in only six weeks.

15. The indestructible Bogade Company -- the newest act, the collapsing newspaper stand

16. Puppchen -- world famous operetta horse of director Alex Blumenfeld.

17. A hilarious bet: The man with a ladder - performed by the original clowns Coco and Alfonso.

18. The Jansly siblings: An equestrian act.

19. Eclair. The floating beam on a roaring motorbike.

20. Closing Procession. ${ }^{129}$

This program illuminates various dimensions of equestrian acts, but perhaps none more clearly than the central role the horse played in rural life. The shows of the Blumenfelds imitated horse shows and jockey riding in the circus arena. Both represented popular activities of large estate owners, who could afford the breeding of expensive luxury horses. Acts 14 and 18 were variations on these themes: the "Freiheitsdressuren von Frl. Amalie Lorch und Herm Alfons Blumenfeld," mimicked the elegant displays of valuable horses. These acts gained their 
particular attraction through the relative immobility of the trainer, who acted as "the patriarchal land owner": remaining almost motionless and effusing dignity, he calmly observed his parading horses from the center of the ring. In another vein, the jockey riding of the Jansly siblings emphasized the sportive and dynamic element of these equestrian acts. All acts were performed by either an important family member of the Blumenfeld clan or a member of closely related German-Jewish circus family -- another a clear sign of the horse's centrality to the show.

In pre-emancipation Germany, large estate owners constituted a social group closed to Jews, who were forbidden to own and cultivate land. Even after legal barriers had disappeared, Jews remained distinctly underrepresented among landowners in the German Empire. In light of this overall under-representation of Jews among rural elites, the Blumenfelds took particular pride in their role as semi-serious landowners. In the pre-war period, the Blumenfeld family had become wealthy enough not only to buy their own circus facilities and their winter domicile, but also to acquire the necessary land to provide for their large stables. In Guhrau, Silesia, they were known to be among the wealthiest landowners in the area. In their selfpromotion the Blumenfeld and Strassburger circuses stressed pastoral elements. It thus comes as no surprise that one of their specialties included displays of strong Kaltblüter -- horses used primarily for heavy farm work -- and presentations of breeding bulls. ${ }^{130}$

Rural elites were not the only members of the traditional elites in Germany who appreciated horses as signifiers of wealth and status. The rural and urban nobility perceived Arabian stallions and fiery racing horses as the ultimate luxury items for the gentry. This dimension of the horse as cultural symbol, emphasizing luxury and exclusivity, constituted an additional reason to make the display of such horses an appealing venture for Jewish circus

129 Dessau, April 1920. A copy of program can be found in the "Blumenfeld" file; documenta artistica collection in the Märkisches Museum Berlin. 
families. Both the acquisition of considerable wealth and the entry to the German nobility were denied to pre-emancipatory Jewry. Until the second half of the nineteenth century, German Jewry had remained part of the poor segments of society. Although German Jewry experienced considerable social and economic advancement in the course of the nineteenth century, noble titles were rarely given out to German Jews and the few that were granted were often not hereditary. The horse allowed the German-Jewish circuses to imitate and appropriate a noble habitus, disregarding past and contemporary social restrictions.

Yet another variation on the theme of wealth and distinction was the participation of traditional elites in high culture. By presenting an operetta horse to their audience the Blumenfelds alluded to the practice of exclusivity in the realm of theater. The operetta horse was an image that captured the "inside/outside" dichotomy of the circus as a genre. Operettas were meant originally to be common parodies of opera. In the course of the nineteenth century, however, operettas ceased to be part of the " counter culture. " The high society of the German Empire embraced operettas, as did ordinary men and women who sang their tunes on the streets of larger cities. Although the operetta mocked the sometimes pompous and pretentious habitus of "high culture," it did not fundamentally question the opera as a cultural institution. The regular visits to the operettas were an integral part of the theater season in every larger German city. The references to the opera "Der Rosenkavalier" in Act 4 of the Blumenfeld circus program in Dessau, as well as "Puppchen, the world famous operetta horse of director Alex Blumenfeld" in Act 16, reflected the prominence and popularity of opera and operetta during the Imperial period.

The horse had held a central function within the military elites. German Jews were denied the rank of an officer in the German army before 1914. Only the emperor's proclamation of the Burgfrieden on 4 August 1914 led to the promotion of Jewish non-

See act 8 in this context. 
commissioned officers throughout the German military. ${ }^{131}$ For the third generation of GermanJewish circus directors, the horse represented a forbidden sphere of society that they mimicked in their horse shows.

The Blumenfelds had always had a special relationship to the military. German-Jewish circus families viewed military service as a fundamental dimension of their German citizenship. Both in the Franco-Prussian War and in the First World War, every adult male who was eligible for military service served in the armed forces. Most Jews volunteered with equal enthusiasm as other Germans. In fact, many German Jews perceived the First World War as a welcome opportunity to demonstrate that they spared no personal or material sacrifice for the fatherland. ${ }^{132}$ The heavy losses of men and material were particularly catastrophic for the traveling circus enterprises because, unlike the stationary circuses, they relied heavily on the participation of family members in both performance and management.

In previous eras, such sacrifices had been considered a question of honor. In 1870, according to the family saga, the patriarch Emanuel Blumenfeld bid his parting sons farewell, exclaiming: "The king has called, go, do your duties, God will take care of me." ${ }^{133}$ During the period of economic hardship in the Franco-Prussian war, a spectator is reported to have held a passionate speech in front of the Blumenfeld circus tent, beseeching the onlookers to attend the circus out of patriotic solidarity. He reasoned that, since the patriarch had sacrificed his three eldest sons to fight against the enemy, the least the audience could do was to support this high

131 Werner T. Angress, "The German Army's "Judenzählung" of 1916. Genesis Consequences - Significance," in Leo Baeck Year Book, XXIII (1978), 118.

132 Werner T. Angress, "Das deutsche Militär und die Juden im ersten Weltkrieg," in Militärgeschichtliche Mitteilungen 19, no. 1 (1976), 78.

133 "The king has called, go perform your duties, God will take care of me." in Saltarino, Das Artistentum, 27; also "Hunderjähriges Jubiläum des Zirkus E. Blumenfeld Wwe." in Das Programm, no. 464, 1911, documenta artistica collection in the Märkisches Museum Berlin. 
minded man by paying a visit to his show. ${ }^{134}$ In 1914 , the call to arms of the various Blumenfeld sons was made known in a special note posted in Das Programm. ${ }^{135}$ Again the sons from various Blumenfeld families were among the first volunteers. Within months, seven of the eight sons of Simon Blumenfeld had been enlisted. ${ }^{136}$

As patriotic Germans, many Blumenfelds volunteered as selflessly as their Christian countrymen. But as entrepreneurs in mass entertainment, they made sure that their potential audiences were aware of these economic and personal sacrifices. From an early date, they sought to establish a high degree of identification with their audiences, appealing either to the patriotism or to the personal honor of their spectators. In the first months of the war, it seemed that the imagined world of harmony and chivalry that they depicted in their performances had become a reality. The heated debate about the German Army's "Jewish census" (Judenzählung)

134 "Ladies and Gentlemen, I do not belong to the circus, I am a visitor of the fair just like youself. I am sorry that the Blumenfeld circus does not make any business due to its competition. Ladies and Gentlemen, the three oldest sons of the old Blumenfeld - the mainstays of his enterprise -- are soldiers in the war against France. The father is deprived of the breadwinners in the family, who sacrifice their blood for the fatherland. Ladies and Gentlemen, it is our duty that we support the circus Blumenfeld with our visit!" Saltarino, Das Artistentum, 28, also "Hunderjähriges Jubiläum des Zirkus E. Blumenfeld Wwe." in Das Programm, no. 464, 1911, documenta artistica coilection in the Märkisches Museum Berlin.

135 "This ancient circus family probably provided the most members to be fighters for the fatherland. Not only the gentlemen Emil, Scherra and Adolf Blumenfeld were called to the arms, but also the grandsons of these gentlemen: Leo and Arthur -- both sons of the enterprise L. Blumenfeld-Menden -- received the order." in Das Programm, no. 647, 1914; documenta artistica collection in the Märkisches Museum Berlin.

136 As Gerda Blumenfeld recalls: "And soon there were not only three but seven brothers Blumenfeld called to arms, five of which served at the front and two at the home front." copy of Gerda Blumenfelds unpublished memoirs: "150 Jahre alter deutscher Circus in 12 
in 1916 , however, led to a rude awakening from their hopes and dreams. ${ }^{137}$ The general disappointment that a war that was supposed to last a couple of months, dragged on for years led to increasing dissatisfaction among the wider population who began to search for culprits for food shortages, stagnating and costly battles and wavering self-esteem of the political leadership.

The First World War constituted a watershed in the aesthetics of circus entertainment. Until 1916, equestrian acts had figured prominently in the shows of most traveling circuses. The trauma of total war not only affected the economic and social situation of all segments of the German population, but fundamentally transformed the spectators' tastes and sensibilities. ${ }^{138}$ Violent death had become a haunting reality that shaped everyday life and transformed the inner lives of the audiences. The nightmares of many Germans resonated in circus and variety shows. Because collective dreams and theatrical illusion went hand in hand, the troubled consciousness of the populace informed the performances of mass entertainers. "Berlin your dance partner is death! howled the advertising columns," recalled the composer and cabaret entertainer Friedrich Hollaender. ${ }^{139}$ Death became the leitmotif in many circus performances and variety shows and displacing former themes such as romance, chivalry, and naive eroticism.

The demand for sensational Todesartistik threatened to marginalize the staple of many circuses: the equestrian acts. Now almost every show had to feature the newest thrill: the fight for life. Key to these acts was the possible failure of the individual performer to survive. It

Jahren Hitler Tyrannei vollkommen ausgerottet!", the original manuscript is in the hands of Gabriela Blumenfeld, Magdeburg.

137 On the Judenzählung see Angress, "The German Army's "Judenzählung," 117-137. 138 For the trauma of the First World War and its reflection in Germany's cultural production see Modris Eksteins, Rites of Spring. The Great War and the Birth of the Modern Age (Toronto, 1989) 
should be noted that the danger to life and limb in the circus arena was real. Anticipation of potential catastrophe dominated the expectations of the audiences and more than occasionally such expectations were fulfilled. ${ }^{140}$ Men catapulted themselves out of cannons into the air, only to be swallowed by gigantic funnel-shaped constructions. An acrobat peddled for his life on a conveyer belt, always in danger of running into sharp spears set up on both ends of the belt. ${ }^{1+1}$ The extensive use of modern equipment and elaborate machines mirrored wartime technological advances. The outcome of these stunts always appeared uncertain, the prevailing mood among the audiences was morbid. Indeed, dangerous stunts were such frequent sights during the war that the police became concerned for the safety of artists and audiences alike. Municipal officials and police administration tried to tighten security controls to provide a semblance of safety in the ring. However, they were patently incapable of resisting this rising wave of sensational stunts.

These new acts were remarkable not only for their content but also for their deliberate attempt to create stars in the ring. Stardom was a new concept in circus entertainment. Previous centuries knew only successful "types" of artists: the clown, the horseback rider, the ballerina. Traveling circuses had begun to react to the growing demand for identification with individual performers mainly by promoting their animals in a personalized manner ("the clever Hans",

139 Friedrich Hollaender, Von Kopf bis Fuß (Bonn, 1996), 68.

140 The contemporary Walter Benjamin reduced this special thrill of potential death to the following formula: "Im Zirkus hat die Wirklichkeit das Wort, nicht der Schein. Es ist immer noch eher denkbar, daß während Hamlet den Polonius totsticht, ein Herr im Publikum um das Programm bittet, als während der Akrobat von der Kuppel den doppelten Salto macht." Walter Benjamin, Gesammelte Schriften (Frankfurt a.M., 1972), Rezension über Ramon Gomez de la Serra, Le Cirque.

14i See photography of man on the bicycle in Martin Schaaff, Die Buschens - 100 Jahre Circus Busch-Bilder einer Zirkusdynastie (Berlin, 1984), 40; as well as man and the canon: 
"Puppchen"). In the nineteenth century, the circus artist was meant to be a member of a community, rather than an individual with a complex personality. The members of a circus understood the circus as collective subject, which defined itself through its parts. The anonymous mass graves of the First World War created the urge for singularity among their survivors. Thus performers whose acts involved life-threatening stunts were introduced to their audiences by name. They plucked their individuality, quite literally, from the jaws of deaths. After the decisive shift in the second half of the war, this star cult only increased in importance during the 1920s.

The new genre of death artistry (Todesartistik) introduced both a new aesthetic to the ring and a new artistic self-definition. In his self-promotion, the artist drew simultaneously on his similarity with other men and his singularity. As Hans Ulrich Gumbrecht has pointed out, a star became an icon of individuality as well as an incarnation of collective identity. "Only a body in performance," Gumbrecht argues, "can be seen by a collective as the incarnation of a specific type of individuality." ${ }^{142}$ These performances undermined traditional concepts of culture and tradition. Only such elementary attributes as strength and speed -- demonstrated particularly in the course of combat with fire, gravity, or pressure -- were consistently accommodated in the ring and appreciated by the spectators.

Death artistry also led to a revision of gender relations in the ring, since most of these sensational acts were carried out by male performers. These sensational stunts created a new gender imbalance in the realm of circus entertainment. Previously, men and women had performed on equal terms. But since the new acts mimicked front experiences -- such as physical and psychological distress expressed through violence, disorientation, helplessness,

"Cliff Aeros - Vom Todesspringer zum Zirkusdirektor," in Gisela und Dietmar Winckler, Allez hopp durch die Welt. Aus dem Leben berühmter Akrobaten (Berlin, 1987), 75-98. 142 Hans Ulrich Gumbrecht, In 1926: Living at the Edge of Time (Cambridge, MA, 1997) 208-209. 
and isolation - they alluded to experiences that were specific to (male) soldiers during the First World War. ${ }^{1+3}$ The violence and power of these front experiences and the novelty of technical warfare heightened the desire for meaning. In an aesthetic framework, German mass entertainment addressed these desires and gave them a universal expression.

The Blumenfeld family thus faced substantial challenges in the aftermath of the war. They had to pick up whatever had been left by state authorities, and they had to reconsider their management and artistic program. In April 1920, the four brothers Alfred, Alex, Arthur and Alfons Blumenfeld established their new headquarters in Magdeburg. In the aftermath of the war their opening night was the source of considerable pride (especially for the younger generation) conceived as the rise of phoenix from the ashes. This opening was their personal victory, celebrated with considerable pathos:

April 3 1920, the traveling circus Blumenfeld Jr. Magdeburg, the oldest existing circus enterprises and family owned for more than 100 years, reopens its gates under a new directorship, after it stood still for six years. Immense successes in Dessau, Halle, Cassel, Erfurt, Plauen, Chemnitz, Breslau and now also Berlin have proven that the Circus Gebr. Blumenfeld Jr., Magdeburg is on top of the world, second to none in quantity and exceeding many in quality. ${ }^{144}$

This première marked not only the resurrection of the Blumenfeld circus, it also was the première of a traveling German-Jewish circus in a stationary arena, an exceptional day for the

143 Klaus Vondung, ed., Kriegserlebnis. Der Erste Weltkrieg in der literarischen Gestaltung und symbolischen Deutung der Nationen (Göttingen, 1980), 25.

144 "The year of our opening was incredibly difficult. Most of our horses had been confiscated, 75 horses were recruited in the first weeks of the war alone. Since our fodder was confiscated as well, our animals suffered from starvation. We lost most of our exotic material as a consequence. No less then three elephants, two camels, three zebras ... etc. died due to malnourishment. Losses occurred on the day to day basis. To not loose 
Blumenfeld circus. As the first Jews to enter the Gentile realm of stationary circuses, the Blumenfeld family was a pioneer among German-Jewish circus families establishing a permanent arena in a medium-sized German city.

Magdeburg was not a random choice of location for such an enterprise. Since 1878, traveling circuses regularly visited Magdeburg, especially during the trade fairs in the fall. ${ }^{145}$ As early as 1893 the Magdeburg city council had approved the construction of a permanent circus arena, hosting 2,890 spectators. ${ }^{146}$ The building included a restaurant and a variety theater. A mobile stage facilitated the staging of concerts and large assemblies. Thus, from the outset, the circus building was meant to be used for other purposes. Given the experiences of other stationary circuses in Hamburg, Berlin, or Vienna, the developers wanted to minimize the potential risks of the Magdeburg stationary circus by supplying an variety of activities and entertainments to their audiences. According to the local press, a limited partnership raised the remarkable sum of $850,000-900,000$ Marks starting capital. ${ }^{147}$ The invitation to buy shares of the Magdeburger Circus-Varieté-Aktiengesellschaft was posted in the local papers on March $31,1893 .{ }^{148}$ Along with other major circuses, the Blumenfeld family had sensed the potential of this brand new arena, whose central location in the German Empire promised high revenues. They filed a request with the Magdeburg police headquarters for eight guest performances as

everything, we sold the rest and only kept "Puppchen" the operetta horse." See "Blumenfeld" file, documenta artistica collection in the Märkisches Museum Berlin.

${ }^{145}$ In 1878 the Circus Althoff was the first larger circus to visit Magdeburg.

${ }^{146}$ The circus hostes 2,890 spectators. There were 170 seats in the boxes, 260 Sperrsitze, 260 Tribüne, 500 seats in first class, 700 seats in second class, 1000 seats in the gallery. See the address book of the city of Magdeburg.

${ }^{147}$ See Dagmar Bremer, "Theater für eine Stadt - dargestellt am Beispiel der Magdeburger Stadtentwicklung von ihrer Ausprägung zu Beginn des 20. Jahrhunderts bis Anfang der 50er Jahre," unpublished Diplomprüfung, Theaterhochschule "Hans Otto," Leipzig 1991; copy in Stadtarchiv Magdeburg. 
early as January 1896 - that is, two years after the official opening of the building through the Circus Renz in $1894 .{ }^{149}$ In 1914 , the Blumenfeld family had already owned the circus building at the Königsstraße $62 / 63$ for several years, yet the land on which the building stood did not belong to them. The circus directors, therefore, negotiated further with the city government: they wanted either to buy the land outright or to sign a twenty-five year lease. ${ }^{150}$ Eventually, the municipal government decided to lease the circus land. In January 1914, Der Artist discussed the advantages of this arrangement for the municipality. It emphasized the considerable economic gains of an enterprise such as the Circus Blumenfeld at a time when local revenues from tourism and the entertainment industry were beginning to exceed those derived from more traditional economic sectors. ${ }^{151}$

Members of the fourth generation of the Blumenfeld family were exceedingly prosperous, as were their contemporaries in the Strassburger family. More significantly, the nature of their wealth had changed considerably since the founding of their respective enterprises. Their forefathers had run successful enterprises without possessing large quantities of capital. The first three generations of German-Jewish circus entertainers were primarily concerned with providing for their numerous offspring by setting them up with their own family enterprises, so profits were reinvested immediately. Most circus families were known to be extraordinarily distrustful of fluctuating currencies, and they avoided inflation by

148 Landeshauptarchiv Sachsen-Anhalt, Rep. C29, tit. IV, 1.3, no. 15, vol. II, 230.

149 Landeshauptarchiv Sachsen-Anhalt, Rep. C29, tit IV, 1.3, no. 15, vol. II, 320.

150 See the long report from Magdeburg in Der Artist, no 1509, January 11, 1914;

Theaterhistorische Sammlung Unruh FU Berlin.

151 "Magdeburg's advantages resulting from a relocation of the Circus Blumenfeld are quite obvious. On the one hand that would lead to the addition of several families in the higher tax brackets, and on the other hand enhance tourism due to frequent circus shows and similar performances." in Der Artist, no. 1509, January 11, 1914; Theaterhistorische Sammlung Unruh FU Berlin. 
exchanging their cash for gold, which some literally hid under their pillows or between false walls in their caravans. ${ }^{152}$ The purchase of a building such as the arena in Magdeburg, however, demanded liquidity on the part of the potential owners. This acquisition must therefore have been preceded by a fundamental change in business practices. This change in strategies was by no means confined to financial transactions. Instead it was a symptom for a larger phenomenon, hinting to a dramatic change in self-perception and life strategies.

One of the most visible indicators for such a shift was the altered attitude towards formal education by the fourth generation of Jewish circus entrepreneurs. By the second decade of the twentieth century, the disregard for Bildung among most circus artists gave way to an appreciation of formal education. Unlike previous generations the fourth generation of the Blumenfeld family left its offspring behind so that the children might attend schools and other institutions of higher education while their parents were on the road. When Karl Döring, a journalist for Das Programm who specialized in reports about the circus milieu tried to trace the different branches of the Blumenfeld family in 1929, he noted that Ruth Blumenfeld had graduated from business school (Handelsschulabschlu $\beta$ ) in Magdeburg, that Arthur and Vicki Blumenfeld's children had attended school in Magdeburg, and Willi Blumenfeld trained as a pharmacist. ${ }^{153}$ Clearly, German-Jewish circus families no longer insisted that their own children aspire a circus career. These parents were aware by the early 1920 s that the circus as an entertainment genre had lost momentum, and was now undergoing substantial restructuring. They no longer regarded a career as a trained entertainer as the highest ideal for their children,

152 Gypsy performers were known to have maintained this practice even longer than others. The story goes that the traveler Petermann had hidden half a million goldmark between fake walls of his wagon. When he was deported to a concentration camp during the Nazi regime, the Gestapo found the money after smashing his entire caravan. Arnold, Fahrendes Volk, 185. 
and instead encouraged their formal training as business people. In opting for the free professions, they followed a traditional occupational pattern among German Jewry, which had always placed special value on professional and economic independence.

When the junior directors distributed proclamations on the occasion of their opening in 1920 , they revealed how conscious they were of their circus's new status in the locality characterized by close-knit social relations and local patriotism. These factors played an important role in whether their circus would win acceptance and integration into the small world of a medium-sized provincial city:

Merchants and artisans of Magdeburg have completed the first tasks needed for the reopening of our enterprise. They have supported us as much as they were able. Today we want to thank them for that. Our new hometown [Heimatstadt] can be assured that we will always try to show only state-of-the-art circus entertainment. ${ }^{\text {IS4 }}$

It seems that the junior directors of the stationary Blumenfeld attempted to continue the path of their fathers, without, however, repeating their mistakes. Whereas a traveling Blumenfeld circus continued to exist, the junior generation directed the stationary circus in Magdeburg, presenting a considerably altered program.

While the stationary circus in Magdeburg was considered an experiment by the older generation, several traveling circuses run by family members of the Blumenfeld clan continued their traditional shows from the pre-war period. The only way to avoid the demands for a new aesthetic in the ring was by exploring new markets, which the Blumenfelds sought mainly in rural Eastern Europe (East Prussia, Poland or Russia), which had failed to develop a competitive variety culture. In addition, the circuses in these areas were known to adhere to

153 Karl Döring, "Wo sind die Gebrüder Blumenfeld?" in Das Programm, September 15, 1929; documenta artistica collection in the Märkisches Museum Berlin.

154 "Mitteilung" documenta artistica collection in the Märkisches Museum Berlin. 
traditional circus aesthetics. ${ }^{155}$ In 1922, they started their first tour of the Baltic states, visiting large cities such as Riga and Kowno. Between October 1924 and March 1925, motivated largely by the attempt to escape German hyperinflation, they set out for guest performances in Soviet state circuses. By this time, the circus Blumenfeld once again matched the larger German traveling circus enterprises in size. ${ }^{156}$

Whereas the traveling circus still centered on a display of equestrian acts, in the stationary circus of the Blumenfeld family these acts had given way to the grand circus pantomimes à la Busch or Renz. Water pantomimes with a highly complicated choreography and technology could be admired by spectators night after night in the glamorous circus building in Magdeburg. The Völkerschauen, too came to the Blumenfeld's venue in Magdeburg in the course of their Tour d' Europe. Perhaps the most modern ring of all echoed from the shouts of audiences that attended the regular wrestling competitions held on the same premises after 1922. Compared to the programs of other stationary circuses of the time, the Magdeburg circus now focused squarely on displays of exotic and foreign worlds, abstaining from the production of openly nationalistic circus shows. Yet because stationary circuses exchanged their programs among each other, and because the pantomimes of Busch in Berlin exerted a considerable hegemony in the realm of entertainment, some of their shows most likely entered the ring of the Circus Blumenfeld in Magdeburg as well.

155 Even in 1930 East Prussia lacked possibilities for individual artists to perform in cabaret or variety shows. Das Programm informed their readers that no artists liked to sign a contract in these regions "because he feared to remain without subsequent employment in addition to the high traveling expenses. Both cabarets in Königsberg are fighting a contstant battle for survival." in Das Programm, June 22, 1930, 28; documenta artistica collection in the Märkisches Museum Berlin.

156 They possesed forty-five horses, two elephants, six camels, three lamas, one guanako, two bulls. 
While the traveling enterprises encountered more and more difficulties to sustain their audiences interest, the Magdeburg circus seemed exceedingly successful. Its fate was sealed, however, when the National Socialists began to organize boycotts of Jewish enterprises in 1927. These boycotts were supported by middle-class organizations that could easily be mobilized against their Jewish competitors. ${ }^{157}$ As early as 1925, smaller cities experienced these boycotts, which mainly targeted visible Jewish enterprises in the textile industry, the cattle trade, or department stores. ${ }^{158}$ From this vantage point we can appreciate that a stationary circus in a medium-sized city close to Berlin involved a high economic risk for the management. More than ever, a good rapport with the audience was crucial for the economic success of such an enterprise. In the case of the Blumenfeld circus, however, this challenge was met only in part. By 1927, the local population no longer identified with "their circus." Magdeburg was one of the early centers of violent antisemitic propaganda of the National Socialist movement. The Blumenfelds, as especially wealthy members of the local population, were among the most "visible" Jews of Magdeburg. Hence it comes as no surprise that they were singled out in the antisemitic brochure, "The Jews of Magdeburg introduce themselves" which dated from the late 1920 s. ${ }^{159}$

Although the Circus Blumenfeld Jun., Magdeburg did exceedingly well between 1925 and 1927, a committee of creditors decided to go into liquidation on September 23, $1927 .{ }^{160}$

157 Moshe Zimmermann, Die deutschen Juden 1914-1945 (Munich, 1997), 43.

158 Ibid., 44.

159 The pamphlet "Magdgeburger Juden stellen sich vor" has no publication date. It lists prominent Magdeburg Jews, including information about their professional occupations and their private addresses. Registration no. $805681 \mathrm{n}$, Stadtarchiv Magdeburg.

160 Das Programm, no. 1332, October 16, 1927; documenta artistica collection in the Märkisches Museum Berlin. 
By 1928 the Circus Blumenfeld Jun. had gone bankrupt. ${ }^{161}$ In retrospect, Alfred Blumenfeld's wife Gerda interpreted this economic failure as the result of rising antisemitism in Magdeburg. Although concessions to the changing times and tastes had been made in the stationary circus, she concluded bitterly, the circus went bankrupt once its former audiences began to accept antisemitic propaganda against the circus family:

The first storm clouds and forebodings of Nazism were revealed in a foul press campaign. Although its devastating effects were still unknown to the general population, even in 1927 -- in the course of a single season -- Nazism knew how to undermine a business that had long struggled successfully through stormy times. To avoid heavy damage to its creditors, liquidation was unavoidable. ${ }^{162}$

By 1927, the Blumenfeld family ceased to be one of the most influential families in the realm of circus entertainment. After the collapse of the last promising circus enterprise in Magdeburg, the Blumenfelds scattered across Europe. Only the younger generation managed to find employment in the booming variety shows or in other Gentile circus enterprises, both in Germany and abroad. While a lack of innovation had undermined the enterprises of the older generation, the younger and more entrepreneurial members of the Blumenfeld clan were swept away by the first wave of violent antisemitism in German local politics. Both generations were driven inte total destitution only a few years later. As Jews, most of them were persecuted and murdered by the Nazis, either in Germany itself or in the occupied territories. Until today their deaths have gone unnoticed.

${ }^{161}$ Arthur Blumenfeld found employement at the circus Dunbar and Schweyer in South America, Alfons Blumenfeld went to the Merano circus in Poland; Alex Blumenfeld went to the Bech-Olsen circus in Denmark.

${ }^{162}$ Gerda Blumenfeld, " 150 Jahre alter Deutscher Circus in 12 Jahren Hitler Tyrannei vollkommen ausgerottet!" Unpublished memoir, private copy in the possession of Gerda Blumenfeld's granddaughter, Gabriela Blumenfeld, of Magdeburg. I am grateful to Gabriela Blumenfeld for permission to consult this important source. 


\section{Conclusion}

The aesthetic, social, and economic successes of German-Jewish circus families coincided with the "Golden Age" of the circus between 1870 and the First World War. German-Jewish circus families had sensed the enormous social and aesthetic possibilities of the circus as the first medium of mass entertainment. Their traditional mobility, their exceptional family structure and social practice attuned them to the demands of this new genre and gave them an advantage over their competitors on the market. Moreover, these families were not only particularly equipped to succeed as circus entrepreneurs, they also found that the circus as a genre offered unprecedented advantages for outsiders such as themselves. Circus entertainment was particularly enticing to German-Jewish circus families for it addressed itself, unlike fairground performances, to a wide range of different social factions within German society. Thus, circus entertainment provided Jewish artists with an unique opportunity to shed the status of marginalized fairground performers to finally become "respectable" members of the German society. To many Jewish managers and performers, circus entertainment offered an opportunity to rise from rags to riches - and not incidentally, also to finally leave the ghetto.

Like no other minority, German-Jewish circus families captured and shaped the dreams of their heterogeneous audiences. Until the First World War, the circus as a medium of mass entertainment managed to communicate to its audiences a vision of social harmony. The inherent ambivalence of circus acts contributed to their universal appeal. These acts alluded simultaneously to bourgeois civic pride, to rural earthiness, and to aristocratic values of social exclusivity and distinction. They reproduced the dominant norms and values and yet they simultaneously challenged them. The circus arena served as a stage on which these families depicted an ideal world of beauty and precision, of chivalrous men and courageous women, of mankind's conquest of nature. In many respects the implied subtext of these diverse acts was remarkably consistent: anything was possible if one only tried. 
German-Jewish circuses presented themselves as a model community, governed by shared beliefs in self-respect, talent, hard work, discipline, and, most importantly, unquestioned happiness and harmony. But the experiences of the Total War and the revolution in $1918 / 19$ made the illusionary character of this vision blatantly obvious to the German population. The dialogue with their audiences had turned into a monologue of the GermanJewish circus families. The universal appeal of the pre-war period was transformed into a particular appeal, confined to segments of the displaced middle classes. High regard for the traditional elites and their world-view gave way to skepticism and despair among the majority of the circus spectatorship. Physical violence, the experience of the trenches, and memories of the 1918 Revolution had shattered the collective consciousness of the German population. Most traditional traveling circuses did not adapt well to the altered realities of life. Their traditional aesthetic failed to reach an audience whose aggression sought an outlet, whose idea of nature had changed drastically, and whose belief in its own strength had been undermined by the "humiliating peace" of Versailles.

Most German-Jewish circus families experienced a drastic change of mentality between their third and their fourth generation, which affected their private as much as their professional lives. Whereas the third generation experienced continuous social advancement in their formative years, the fourth generation was primarily concerned to preserve the heritage of their fathers. While the third generation spent their youth in a peaceful and prospering country, which was about to secure itself a place under the sun, the experiences of total war and postwar upheaval shaped the fourth generation's world view. The latter no longer held to the same values as their father's generation, and tried to alter their lives accordingly. They began to question the exclusive social structure and sociability of their families. This generation was the first to marry outside of the small circle of German-Jewish circus families, occasionally choosing a Gentile partner. 
These two competing mentalities can also be traced in the aesthetic and the organization of the various circuses. In 1920, German-Jewish circuses which had traditionally been traveling circuses centered on equestrian acts made their first attempt to establish themselves in the Gentile realm of stationary circus (Pantomimenzirkusse). While the senior generation continued to stage horse shows, relegated to touring Eastern Europe, where cultural traditionalism, a rural life-style, and a lack of competition promised a continuation of past successes, the junior generation opened their first stationary circus in Magdeburg with a conspicuously "modernized" program. But even this enterprise could not survive for long. Violent National Socialist propaganda began to brutalize Magdeburg politics as early as 1927 , and the Blumenfeld family, including members of the third and fourth generations, was one of its first victims. When confronted with both an economic crisis and Nazi antisemitic hate campaigns the Blumenfeld circus went bankrupt. But it did not suffer this fate alone. As antisemitism permeated the German public sphere in the late years of the Weimar Republic most Jewish circuses, which had barely survived the First World War, proved similarly illequipped to resist this development. 
II Comic Relief: Jewish Identities in Jargon

Theater from 1890 to the 1920 s 


\section{Chapter 5 Jargon as Art}

Prior to the First World War, countless Germans sought release from their regulated and restrained lives in Jargon theaters. To date, however, the subject of Jargon theaters has not received much scholarly attention. Whereas the reception, the artistic quality and tradition of Jargon theaters in Berlin's drama scene remain contested among the handful of historians or literary critics who have addressed the topic, all interpretations agree that Jargon theater was not only a popular theater, but one that focused on "Jewish themes." Between the 1890s and the 1920s, Jargon theaters flourished especially in Berlin, though not only there, and they held a prominent place in the expanding entertainment industry. They were the only theaters in Germany in which the majority of stage characters were of Jewish descent and, through their performance embraced, problematized and even satirized their own Jewishness. Jargon theaters presented slapstick comedies and one-act shows that amused hundreds of spectators every night. Their ethnic humor, which ridiculed all segments of society, was appreciated as a unique contribution to Germany's rich popular entertainment scene. The most prominent Jargon theaters were the Gebrüder Herrnfeld Theater and the Folies Caprice, both of which were imitated by other theater companies at the time. The exceptional commercial success of these two prominent Jargon theaters enabled their directors to accumulate considerable wealth over a period of several decades. These entrepreneurs became the incarnation of the newly rich in Berlin's entertainment scene.

Any discussion of the reception, representation and aesthetics of Jargon theaters has to start with a brief attempt to define this unique form of popular Jewish drama. The contemporary label "Jargon" had a normative connotation. Jargon theaters clearly owe their name principally to the language employed by their actors. As will be shown, contemporaries often used of the word "Jargon" interchangeably with "Yiddish." In the 
realm of theater, "Jargon" came thus to be used almost exclusively for popular Jewish entertainment. Jargon held two competing meanings: it was an ironic self-description employed by the performers, and it was simultaneously a denigrating ascription of Jewish dialect theater by its middle-class audiences. The often derogatory label "Jargon" carried the stigma of linguistic impurity and originally had a more universal meaning, distinguishing any dialect from Hochdeutsch (High German), the language of elite circles in German society. The distinction between "Jargon" and "High German" alluded to an ethnic, a geographic, or to a class dimension. The often amorphous term "Jargon" was meant to describe the multiplicity of linguistic origins, pointing to its oral dimension and its specificity to an identifiable milieu.

The following chapter discusses the genre itself and its perception by historians. Chapter six introduces the historical protagonists of Jargon theaters, their families and their private lives. Specific attention will be paid to the individuals' upbringing, childhood, friendships and other formative experiences, providing the background for chapter seven, which analyzes Gentile and Jewish relations beyond the stages of Jargon theaters. Section II of this dissertation concludes with chapter eight exploring the specific aesthetics employed by Jargon theaters, centering on the reading of texts and images.

\section{Jargon Theater Revisited}

Jargon theaters have remained a blind spot in the history of German drama and GermanJewish culture. 'Drama studies have ignored them almost entirely, and studies of GermanJewish culture evaluated them in solely negative terms. Peter Sprengel's recent monograph

1 Ruth Freydank's monograph, Theater in Berlin: Von den Anfängen bis 1945 (Berlin, 1988), does not even mention the Hermfeld Theater. The same is true of idem, ed., Theater als Geschäft (Berlin, 1995). 
is exceptional in this regard. ${ }^{2}$ Sprengel takes an unprecedented interest in the medium itself. He carefully analyzes the daily life and routines of performers and performances, painting a compelling picture of the popular theater scene in pre-1933 Berlin. Nevertheless, although he succeeds in establishing and legitimating a scholarly interest in popular Jewish theater, his evaluation of the reception of this popular Jewish theater is less convincing. Whereas he rightly points to the richness and vitality of Jargon theaters, he underestimates its impact on Gentile audiences, insisting that this form of popular Jewish theater was theater "by Jews for Jews."

By contrast, this chapter argues that at the turn of the century Berlin Jargon theaters emerged as a part of a newly-expanded public sphere. This public sphere allowed Gentiles and Jews, men as well as women, to interact outside the constraints of the workplace and the limitations of domestic intimacy. These popular Jewish theaters became a staple of the theater scene in Berlin and elsewhere, catering to the urban middle-classes in pursuit of pleasure and distraction. Far from being a marginal phenomenon for marginalized people, Berlin Jargon theaters provided a unique meeting ground for Gentiles and Jews. More important still, they moved the question of a German-Jewish identity to the center of public attention. Jewish spectators experienced their particularity in the presence of Gentiles. Far from reaffirming their ethnicity exclusively in the spheres of family, Jewish associations or friendships with other Jews, the Jewish audience of Jargon theater expressed their Jewishness among Gentiles. Indeed, both factions of society, Gentiles and Jews, not only tolerated but also appreciated the other's presence in these theaters. Difference was not necessarily considered problematic in the realm of Jargon theater, but found its release in the communal laughter of Gentiles and Jews. It is the particular quality of Jargon theaters as sites of Gentile-Jewish encounters as well as sites of continuous negotiations between competing and conflicting visions of a German "Jew" that make these theaters so rewarding

2 Peter Sprengel, Populäres jüdisches Theater in Berlin von 1877 bis 1933 (Berlin, 1997). 3 Sprengel, Jüdisches Theater, 7. 
for an analysis of Jewish identities in German society at large.

Sprengel's judgment that Jargon theater was confined to a Jewish milieu reflects his neglect of the larger context of Gentile-Jewish relations in German society. As a literary scholar, Sprengel focused on a discussion of the theater manuscripts at two different stages of production: as they were handed to the Prussian censorship authorities before theater directors could mount their plays, and as they were evaluated by the theater police who actually attended performances. Sprengel's concentration on texts represents simultaneously the greatest strength and weakness of the book. Whereas his analysis of scripts is thought-provoking, one is often left wondering what motivated the changes in representational styles, on the one hand, and in the nature of their reception by the audience and the police, on the other. Although Sprengel gives an impressive inside view of popular Jewish theater in Berlin, he provides only a rough sketch of the general context of GentileJewish relations in Imperial and Weimar Germany. Thus, although the reader is introduced into the daily life and struggles of the two contemporary theater directors, Anton and Donat Hermfeld, he or she is left to ponder the importance and the impact of the rise of antisemitic rhetoric and practice on Jargon theater entertainment during the First World War. Equally neglected is the effect of a growing Zionist movement in Central Europe, one of the most critical inner-Jewish voices against Jewish assimilation in Germany. Finally, the complex and central relationship between eastern European Jewish immigrants (Ostjuden) and assimilated German Jews is explored only tangentially. As will be shown, all of these issues significantly affected Berlin Jargon theater; all must be factored into any reading of its aesthetics and its reception by German audiences.

Michael Brenner's study, The Renaissance of Jewish Culture in Weimar Germany, is one of the few works on Jewish identities in modern Germany that makes reference to popular Jewish theater. Brenner devoted some attention to the Gebrüder Herrnfeld Theater, 
one of the leading Jargon theaters of the time. ${ }^{4}$ Unlike Sprengel's account, Brenner does not explore the social reality and the inner lives of Jargon theaters, their protagonists or plays; his study does, however, engage in a discussion of German-Jewish identity in Imperial and Weimar Germany, contextualizing Jewish culture in the wider framework of German society. Despite the larger scope of the book, Brenner based his brief evaluation of the Herrnfeld theater almost entirely on the testimony of Weimar intellectuals such as Alfred Döblin (1878-1957), one of the most eminent Jewish novelists and journalists in Weimar Germany. These intellectuals, retrospectively, accused the directors of the Gebrüder Herrnfeld Theater of exploiting Jewish themes for commercial success. Michael Brenner's study provides a thoughtful analysis of this emerging German-Jewish avant-garde culture eager to respond to the unprecedented wave of antisemitism in the early years of the Weimar Republic. ${ }^{5}$ But by accepting the perspective of Weimar intellectuals, Brenner fails to do justice to the originality and importance of Jargon theater as middle-class entertainment in Imperial Germany.

By the beginning of the Weimar period, Jargon theaters had already lost much of their popularity or had simply ceased to exist in their commonly known form. Alfred Döblin's recollection of Jargon theaters was clearly informed by his sense that JewishGentile relations deteriorated dramatically in the early years of the Weimar Republic. These concerns informed Döblin's praise of the Vilna Yiddish theater, which toured Germany in the early 1920s, but they did not lead Döblin toward a sensitive evaluation of pre-war

4 Michael Brenner, The Renaissance of Jewish Culture in Weimar Germany (New Haven, 1996).

5 Uwe Lohalm, Völkischer Radikalismus: Die Geschichte des Deutschvölkischen Schutz- und Trutzbundes 1919-1923, (Hamburg, 1970); Dirk Walter, "Antisemitische Kriminalität und Gewalt in der Weimarer Republik," (Ph.D. dissertation, University of Freiburg, 1997); Saul Friedländer, "Die politischen Veränderungen der Kriegszeit und ihre Auswirkungen auf die Judenfrage," in Werner E. Mosse, ed., Deutsches Judentum in Krieg und Revolution 1916-1923 (Tübingen, 1971), pp. 27-67; Anthony Kauders, German Politics 
Jargon theater. Döblin envisioned the performances of the Vilna Yiddish theater as "spontaneous cultural achievements of a vital people," far superior to the "self-prostituting scheming" of the Herrnfeld Theater. ${ }^{6}$ His aversion to any subjection of Jews to ridicule and laughter was paired by his animosity toward unsophisticated mass audiences. Döblin's retrospective testimony should be read as a polemic attack against a specific concept of Jewish identity and assimilation in Germany in a period of mass consumption.

\section{The Linguistic Origins of Jargon Theater}

Most scholars have assumed that Jargon theaters were rooted in traditional Yiddish theater and were therefore sites of entertainment for working-class Jews, impoverished and isolated from their Gentile environment. Focusing on the intellectual achievements of middle-class German Jews, the historiography of German-Jewish relations has often viewed Jargon theaters as theater on the margins of Germany's cultural sphere. This approach led to the wide-spread belief that Jargon theaters owed their success to the unassimilated Jews of the Scheunenviertel, a run-down neighborhood on the east side of Berlin that hosted many Jews from Eastern Europe (Ostjuden), along with other destitute elements of society. A closer look at both Yiddish and Jargon theaters demonstrates, however, that this assumption is misleading.

Yiddish, the language of the Ashkenazim (Northern and Eastern European Jews), developed out of Middle High German during in the Middle Ages. ${ }^{7}$ Migrating eastwards, Jews integrated elements of Polish and Russian in addition to Hebrew into their language. ${ }^{8}$

and the Jews: Düsseldorf and Nuremberg, 1910-1933 (Oxford, 1996).

6 Alfred Döblin, Kleine Schriften, ed. W. Riley, vol. I (Olten, 1985), 365-366.

7 See David S. Lifson, The Yiddish Theater in America (Cranbury, 1965),

8 Lifson, "Yiddish Theatre," 550; see also N. Sandrow, Vagabond Stars: A World History of Yiddish Theater (New York, 1986). 
Historians agree that Yiddish theater can trace its roots back to the purimshpil (Purim Play), which is based on the Biblical account of Esther's victory over Haman. The first performance of a Purim play reportedly took place around A.D. 415 during the Purim holiday. ${ }^{9}$ Originally a spontaneous act, it quickly developed its own script, and eventually a play was formally enacted. By the late eighteenth and early nineteenth centuries, Yiddish theater began to flourish, as playwrights and intellectuals realized that they had to communicate in Yiddish in order to reach the masses. By the first half of the nineteenth century, uneducated Jewish workers and impoverished town-dwellers began to enjoy Yiddish comedies, historical and Biblical dramas, and musicals.

Yiddish theaters flourished in many large German cities by 1900 . They provided entertainment for thousands of Jews who had escaped antisemitic persecution and violence in Russia. ${ }^{10}$ These dislocated refugees, stranded in a foreign world, tried to preserve their cultural heritage on the stages of Yiddish theaters, in order to foster a sense of belonging based on their shared history. These theaters represented a safe haven from a potentially hostile environment; temporarily mitigating the hardships the unassimilated émigrés experienced.

Jargon theaters did not stem directly from these traditional forms of entertainment, but often coexisted with Yiddish theaters. Jargon theaters in Berlin, such as the Gebrüder Herrnfeld Theater and the Folies Caprice, were by no means mere continuations of a specific ghetto entertainment, as Brenner and others have assumed. Instead they represented more recent responses to Jewish emancipation and assimilation in Germany. Jargon theaters did not stage Yiddish dramas, for the simple reason that their audiences would have been unable to follow the dialogues on stage. Yiddish was not easily mastered

9 Lifson, "Yiddish Theatre," 550.

10 After the assassination of Czar Alexander II in 1881, pogroms against Jews had escalated in the Russian Empire and had led to massive migrations of Eastern European Jews to Western Europe and the United States. The successive crises eventually forced more than 2 
by audiences of Gentiles and assimilated Jews. Instead, Jargon theaters invented a "Jargon," a mixture of Yiddish, Rotwelsch, French, Bohemian, Russian, German and whatever local dialect seemed to appear "authentic." Far from being sites of refuge from a hostile majority culture, they were both an integral part of a broadly engaging popular culture and celebrations of assimilated Jewish life in Central Europe -- a life in which both Jews and Gentiles participated. Jargon theaters reflected the self-confidence of an ethnic minority and its role in a modernizing, and increasingly mobile society. Although they made reference to the aesthetics of traditional Yiddish theaters, they differed starkly from those theaters in atmosphere, motivation, audiences and - most importantly -- language.

\section{The Reception of Jargon Theater}

Jargon theaters were deeply rooted in the tradition of music hall and variety entertainment. Through their immense success and flexibility, they managed to establish themselves permanently in Berlin's popular theater scene. The rise of Jargon theaters was thus a byproduct of the rise of variety entertainment, and along with the latter, it experienced a phenomenal success by the turn of the century. In many ways Jargon theaters were set in the twilight zone between variety theater and classical theater. Although they originated in the glittery world of cheap mass amusement, they managed to establish themselves as spaces of bourgeois sociability by 1900 . Their physical location within the urban landscape, continuously moving westwards to the fashionable districts of Berlin and into more and more upscale theater buildings, reflects this increase in form and status.

Next to circuses, variety theaters became the main form of live entertainment, affordable for most segments of society. "By the first decade of the twentieth century,

million Jews to emigrate to the west.

11 On Variety entertainment in modern Germany, see Wolfgang Jansen, Das Varieté. Die 
entertainers in Jargon and variety theaters felt that general public acknowledgement of their sincerity and craft was long overdue. As one contemporary observed, just as circuses had become temples of amusement unmatched in their elegance and splendor, variety theaters strove to provide their audiences with a distinguished atmosphere of wealth and leisure. Not only the inner decor had improved dramatically, but the architectural designs now satisfied even the most demanding customer. Instead of being unruly sites of the infamous Lumpenproletariat, variety entertainment became a staple of middle-class amusement:

What did our theaters look like only twenty years ago? Smoky bars, pubs, taverns just for coachmen .... [T] oday one builds palaces for the artistic world and erects magnificent buildings comparable to the most distinguished stages. Today, these theaters are visited by the most high-ranking and refined audience -- in short, today the variety has gone to court! That is probably our greatest success: unlike fifteen years ago, the artist has ceased to be a pariah! The former romanticism, about which I myself have written so much, is over; the economic situation of the artist has become middle-class, and the terms "employee - employer" make reference to the Realpolitik that has become common-place among the "traveling people." A healthy and reasonable Realpolitik! ${ }^{12}$

Twentieth-century popular entertainment became increasingly dependent on mass audiences, pouring from the vicinity of Berlin to seek distraction from their increasing regimented lives. Theaters boomed and expanded in order to satisfy the desires of spectators with free time and money to spend. Far from being isolated and bound to a specific milieu, Jargon and variety theaters profited from travelers making the occasional visit to the metropolis. ${ }^{13}$-- The Gebriider Hermfeld Theater, for example, was temporarily

glanzvolle Geschichte einer unterhaltenden Kunst (Berlin, 1990); Ernst Günther, Geschichte des Varietés (Berlin, 1981); useful as a contemporary source is Eberhard Buchner, Berliner Varietés und Tingeltangel in Berlin (Berlin and Leipzig, 1905).

12 Oscar Geller, "Die Reform des Varietés," in Das Programm no. 434, 1910; documenta artistica collection in the Märkisches Museum Berlin.

13 For a recent study of modern mass tourism in Germany, see Christine Keitz, Reisen als Leitbild: Die Entstehung des modernen Massentourismus in Deutschland (Munich, 1997). 
situated immediately next to one of Berlin's main train stations. It boasted its own entrance to the train station, in order to facilitate the visits of tourists. ${ }^{14}-$ Both genres, Jargon theaters and variety theaters not only encouraged their visitors through well-organized advertisement campaigns, special offers and subscriptions; they also sent their seasonal shows on the road in order to reach small-town audiences. ${ }^{15}$ These popular theaters became highly dependent on an uninterrupted stream of visitors in order to cover their high maintenance costs. As a result, they were often forced to appeal to the most common aesthetic denominator.

Unlike circus entertainment, which managed to establish the myth of a long history dating as far back to antiquity, variety entertainment presented itself to its audience as a new and modern form of live entertainment. Along with the department stores and warehouses mushrooming in every major German city, they became potent symbols of the modern urban experience. Variety shows were seen as assembly-line entertainment for an audience with a short attention span. They broke with the traditional self-representation of popular performers as members of the early-modern ganzes Haus, a vision that had been carefully nurtured by circus entertainers. Instead, variety entertainment made deliberate references to the world of industry and commerce -- worlds of modernity with which they were increasingly associated. As one theater director wrote in 1904:

Just as the big bazaars and department stores -- Louvres, Wertheim, Tietz -- attract a greater clientele because they are able to offer big advantages due to their centralized acquisition and redistribution of goods, I foresee a similarly great future for the modern smoke theater, because it does not pursue a one-sided course. ${ }^{16}$

14 Egon Jameson, Mein lustiges Spree-Athen (Berlin, n.d.), 62.

${ }^{15}$ In 1911 the Folies Caprice-Ensemble, Berlin toured in the Walhalla-Theater in Magdeburg (January), the Eden-Theater in Hamburg (June-July), and in the Central-Theater in Liegnitz (August). Brandenburgisches Landeshauptarchiv, 30 Berlin C, Tit. 34, Th. 1469, Akt. 34. 16 "Zur Entwicklung des Varietés. Kulturhistorischer Rückblick von Direktor E. Waldmann in Budapest," in Das Programm, no. 100, March 6, 1904; documenta artistica collection in the 
To a greater degree than circus entertainment, variety shows became the site of a renewed debate about core values in German society. It was their modern, openly commercial nature that provoked a wide range of responses among their "respectable" observers. The professionalism of most performers shook one of the most important pillars of the fragile edifice of middle-class respectability: the ethos of the amateur. This was particularly marked in the world of sports, where both middle class and working class associations resisted any form of professionalization. The occasional athlete who dared to change "camps" and became a professional artist in variety entertainment ran the risk of being viewed with disdain by his former peers. Professionals were seen as symbolic representatives of a commercialization that threatened to penetrate all spheres of society and offended the advocates of beauty and vitality. ${ }^{17}$ Contemporary cultural critics frequently viewed acrobats in variety entertainment as symbols of the increasing moral decay of modern times, desecrating the traditional concept of culture by prostituting themselves to whomever was willing to pay for their art. Contemporary entertainers deplored these notions with a mixture of anger and anxiety:

Law and order is handed down like an eternal illness, and in certain philistine and pettybourgeois circles clinging stubbornly to old-fashioned views, one looks contemptuously upon the variety theater, degrading it as a trade and profession or portraying it as an immoral institution, catering to the debased instincts of the masses by prostituting art. ${ }^{18}$

Märkisches Museum Berlin.

${ }^{17}$ Martin L. Müller, "Turnen und Sport im sozialen Wandel. Körperkultur in Frankfurt am Main während des Kaiserreichs und der Weimarer Republik," in Archiv für Sozialgeschichte 33, 1993, 118; on the relationship of politics and the Turner associations: Dieter Düring, Organisierter gesellschaftlicher Nationalismus in Deutschland (1808-1847). Bedeutung und Funktion der Turner- und Sängervereine für die deutsche Nationalbewegung (Munich, 1984), Svenja Goltermann, Der Körper der Nation (Göttingen, 1998).

18 Dr. Adolph Kohut, in Der Artist, no. 1206, March 12, 1908; documenta artistica collection in the Märkisches Museum Berlin. 
It was in this context of continuing cultural criticism that framed any discussion of Jargon theater at the turn of the century. It was the mixture of commerce and Jewish identity that led to an official disrespect for Jargon theaters. However, this rhetoric, though shared by avant-garde intellectuals and petty bourgeois philistines, should not lead us to underestimate the resonance Jargon theaters found among their audiences during the Wilhelmine period.

\section{Jargon Theater as Volkskultur}

The ethnologist Hermann Bausinger has described the nineteenth century as a period in which the Bürgertum took an increasing interest in the aestheticisation of folk culture (Volkskultur, as it was labeled then). Germany's longstanding federal tradition had encouraged a middle-class interest in regional and local dialects and customs; but as Bausinger points out, "it was a filtered folk culture, freed from all ballast." ${ }^{19}$ This folk culture appropriated regional histories and local traditions, rejecting most expressions of mass culture. ${ }^{20}$ Dialect theater such as the Gebrüder Herrnfeld Theater profited from this interest in local and ethnic differences; and although not part of a bourgeois cultural canon in the strict sense, were nevertheless sanctioned by the middle classes. Volkskultur in the late nineteenth and early twentieth centuries was intended to form one community, encouraging all segments of society to embrace one cultural canon. ${ }^{21}$ It was the integrative nature of Volkskultur that seemed to be a venue for visibly Jewish entertainers to find appreciation in mainstream entertainment.

Jargon theater entertainment, and their humorous one-act plays in particular,

19 Bausinger, "Bürgerlichkeit und Kultur," 137.

20 Ibid., 137.

21 Ibid., 139. 
focused heavily on the daily quarrels in average Jewish families. They temporarily managed to bring their heterogeneous audiences together, sketching Jewish family life in Germany and Austria-Hungary as loving, often sentimental, at times crude, and always comical. They did not confine the setting of their plays to Germany alone, but instead included other German-speaking countries. Much like circus entertainment, they fostered a specific brand of nationalism that was based on the notion of a shared German culture, emphasizing the bonds of a common language, an historical heritage, and moral or political conservatism. The rejection of a völkisch nationalism is not surprising, for it guaranteed Jews inclusion into German society at large.

Jargon theaters as an integral part of middle-class folk culture opened up a new range in the dramatic representation of Jews. Unlike most classical theaters, which provided only the occasional Jewish character in a drama for and by Gentiles, in Jargon theaters almost all actors and stage characters were Jewish, so that a Jew did not stick out by virtue of being Jewish. In addition, Jargon theaters provided Jewish character roles outside the limitations of traditional characters such as Shylock, Nathan the Wise, Golem or Dybbuk. In addition, male Jewish roles were not confined to the haggling Jew (Schacherjuden) and the money-grabbing father figures who inevitably drove their daughters into prostitution. Male actors were able to impersonate young Jewish lovers, for example -- a role absent in the classical tradition, in which the Jew provided the negative contrast to the Gentile hero. ${ }^{22}$ In short, Jargon theater depict Jews as many things, but never solely as social pariahs.

Jargon theaters such as the Gebrïder Hermfeld Theater or the Folies Caprice were dialect theaters with a special flair. Marriages, adultery, generational and gender conflicts formed the core of their plays. None of these topics were Jewish topics per se. They were set, however, in Jewish families and homes, suggesting that themes discussed within

22 See Hans-Joachim Neugebauer, Judenfiguren. Drama und Theater im frühenen 19. Jahrhundert (Berlin, 1994). 
Jewish families were simply a variations on themes discusses in Gentile families. Jargon theaters were spheres in which difference was articulated without being alienating. At a time when regional identities were reinvented in many folksy theaters across Germany, Jews in Berlin claimed their own dialect theater, thereby suggesting that what they presented as Yiddish was yet another dialect -- different but equal -- among the many German dialects in Central Europe. Until the First World War, Jargon theaters were part of a seemingly successful emancipation of Jews in Imperial Germany. The extent and limitations of the integrative forces at work in this new public sphere only became apparent during the First World War. 


\section{Chapter 6 Life in Jargon Theater}

The Gebriider Herrnfeld Theater was the first theater in Germany to allude openly to the Jewish identity of its actors. It provided the model for most other Jargon theaters, of which the Folies Caprice in Berlin was the most successful. While Jews had traditionally been among the leading actors in German drama, they had been discreet about their ethnic background. Their reserve had been mainly due to the open discrimination against Jews in German society preceding their legal emancipation in 1869. For many Jews, the common practice of taking on a stage name fulfilled a dual function: it enabled them to shed their ethnic origins and, in a related vein, made them appear more marketable and exotic. By the early twentieth century, however, many actors no longer concerned themselves with their Jewishness in public. The most impressive examples of assimilation among Jews in German drama -- such as Max Reinhardt, the above mentioned Otto Brahm, or the famous actress Elisabeth Bergner -- saw themselves as German actors who happened to be Jewish. They considered their ethnic origins a private matter and felt passionately about their innovative role in German drama, the creativity and artistic energy of which exerted an enormous influence on European drama at large.

At the turn of the century, the brothers Anton and Donat Hermfeld created the Budapester Possentheater. This new genre in popular live entertainment soon became a brand name for ribald Jewish humor and slapstick comedy with strong sexual undercurrents. The new form of entertainment invented by the Herrnfeld brothers became the model for many other Jargon theaters in Berlin and elsewhere. Its influence can even be felt in the early silent slapstick movies of the 1920s. Both Herrnfeld brothers were born in Hungary, and both were brought up in Bavaria, while their German-Jewish parents toured as comedians in Central Europe. Although their Hungarian roots existed merely on paper, the Herrnfeld brothers carefully portrayed themselves as Hungarians in public, hoping that 
the reference to Budapest would grant their show just enough flair to appear exotic, without, however, alienating their Berlin audiences. At the time, references to AustriaHungary were as frequent as they were fashionable: Vienna still claimed to be the unrivaled capital of music and theater, while Hungary was famous for its live entertainers. Many entertainers, in fact, toured both countries; and a success in one was a strong recommendation in the other.

Little is known about the early years of the Herrnfeld siblings, but in all likelihood they underwent only rudimentary formal schooling. Born into a family of comedians, they were introduced to the necessary professional skills by their parents. Constantly traveling, they were exposed to a never-ending change of scenery and language, which must have challenged and improved their social skills, their keen sense for observation, and their aptitude for survival. The Hermfeld siblings were what contemporaries in the entertainment industry called "Erbartisten," artists who were born into the business. ${ }^{23}$ Their careers were in many ways typical for their generation of variety performers. It was not until the second decade of the twentieth century that the entertainment industry saw a considerable influx of "outsiders," individuals who were not raised in the business.

The unique circumstances of a childhood in variety entertainment attracted the attention of many bourgeois novelists. By the early twentieth century, a wide readership devoured the countless "authentic" memoirs of performers. Readers were scandalized by romanticized notions of a life in the limelight. These fantastic exposés seldom corresponded to the tiresome routines that characterized everyday life on and behind the stage. By contrast, Das Programm or the Internationale Artisten Almanach, both contemporary journals for professional performers provide a unique window into the daily lives of popular entertainers. Accounts such as the following one by the variety performer $\mathrm{C} . \mathrm{H}$. Unthan are invaluable for their intimate portrayal of the social reality. Besides providing one of the most accurate descriptions of a childhood in variety entertainment at this time. 
Unthan's testimony captured the double-edged experiences of child performers -- the unique opportunities, but also the constraints, that set them apart from their peers:

Born on the road in one country or another, during performances they are left for safekeeping at the coat check in a basket or on a bundle of costumes. As soon as they can walk, they mimic everything and bounce from pillar to post until they are four or five years old. Then the serious life begins: training of the body. By the time they are school age they have passed through half a dozen countries, they have spoken and forgotten as many languages. They speak the language of the country they are in, and with their families they speak the language of their mother, which the father has not always mastered. .... What is a teacher to do with children who understand him poorly or not at all, and for whom he can have no sympathy because they are from a social class that is totally alien to him? ... In this way the children, of course, did not acquire much school knowledge. They, as their families, are content with being able to write a letter which, despite all its mistakes, is intelligible. They make up for it by attaining good manners through their contact with strangers, by learning to be keen observers, and by acquiring knowledge by eavesdropping, in areas that are inaccessible to the sedentary good student. The latter also absorbs what he hears, but that information gets lost in the monotony of everyday life which rarely, or never, allows him to develop his own thinking and opinion, whereas the hereditary artists with all his achievements can stand on his own very solid ground. ${ }^{24}$

According to family legend, Anton followed the example of his comedian forebears and began his professional career when he was only 8 years old. Three years later he and his siblings Donat (9 years old at the time), Käthe (7) and Ella (5) started their first family production with a black-face masquerade ("Neger-Quartett") in the popular Vienna

23 The literal translation of "Erbartist" is "hereditary artist."

24 The defensive undertone that echoes in Unthan's article, reflected not only the increasing fear of outside competition, but also the author's need to justify the absence of any formal education in the lives of most Erbartisten. In 1925, variety entertainment was far from marginal, and consequently the pressure had increased to conform to the hegemonic cultural canon. C.H. Unthan, "Der Artist als Weltwanderer," in: Internationaler Artisten Almanach (Berlin, 1925), vol. 35, documenta artistica collection in the Märkisches Museum Berlin. 
Ringtheater. ${ }^{25}$ From the outset, these entertainers created and reinvented their ethnic stage personae, be it black or Jewish, to please their respective audiences. They spoke several languages, were experienced and worldly entertainers with an impressive international exposure. The Herrnfelds were well acquainted with the international trends and customs in the entertainment industry, and even as child performers they had learned to pay particular attention to regional, national and ethnic differences in speech and gesture. These experiences would provide them with a rich and versatile array of dialects, postures, and ethnic and religious stereotypes on which they could draw in their later careers. At the time, variety theaters were acclaimed for the internationalism of their performers and the exoticism they presented on stage. Paradoxically, was this international world that provided a domestic haven for the young Herrnfeld siblings. ${ }^{26}$

The professional training of the Herrnfeld brothers thus began long before they came to Berlin. Although they were only 17 and 18 years old when they started their exceptional careers in Jargon entertainment in Berlin, they had already undergone many years of training as variety entertainers. Anton and Donat Herrnfeld operated as a comedy team, which allowed them to form a community, the specific relations of which constituted the core of every play and thus ran like a red thread through most of their productions. Although Anton and Donat Herrnfeld altered the setting and the personal background of their stage personae, they always related to each other in the same way. Like the Marx Brothers or Laurel and Hardy in American film entertainment, the Herrnfeld brothers took

25 Jameson, Spree-Athen, 63.

The following quotation from the entertainer Hans Heinz Ewers captures the unique nature of variety entertainment as it presented itself to young performers such as Anton and Donat Herrnfeld: "Nothing makes us more aware of the fact that all countries in the world are growing closer to each other daily than the Variety theater, where we see Japanese floor gymnasts, Indian magicians and Egyptian dancers. These are constantly new and gripping pictures." Hans Heinz Ewers in Der Artist, no. 1206, March 12, 1908; documenta artistica collection in the Märkisches Museum Berlin. 
on characters that remained surprisingly constant from play to play. ${ }^{27}$ These celebrated film stars were certainly aware of and profited from the long tradition of comedy teams in live entertainment, of which the Hermfeld brothers were two of the more prominent representatives in fin-de-siècle Berlin. Closer to home, this tradition also informed Berlin's cabaret entertainment in the 1920s, when comic dialogue became a staple in most shows.

The Herrnfeld brothers founded the Gebriider Herrnfeld Theater in $1906 .{ }^{28}$ By that time, the two had lived in Berlin for almost a decade, performing in various variety theaters and hotels. They made their initial appearance on a Berlin stage in 1891, and started their first entertainment enterprise in 1897 with the Kaufmanns Varieté, a popular Berlin variety theater. ${ }^{29}$ Even before the brothers could afford their own theater, they presented themselves as an independent entertainment unit whenever they could find employment. They habitually rented a theater with a license to perform and advertise their plays under their own name. This practice, although contrary to the official stipulations of the Prussian theater police, allowed for a high degree of identification between audience and performers and helped the Herrnfeld company to establish a strong reputation relatively quickly. These early years of appearing at different local theaters were key to the brothers' widespread popularity among locals and tourists alike. The Hermfelds could be found at the elegant Wintergarten as well as in the Reichshallen Theater or the Quargs Vaudeville in the Grand Hotel. They never forgot that they owed their initial success at least in part to the suburban audiences. Throughout their careers they sustained and reestablished this rapport, regularly

27 For an excellent study of ethnicity and humor in American entertainment, see Mark Winokur, American Laughter. Immigrants, Ethnicity, and 1930s Hollywood Film Comedy (New York, 1996), 19.

28 Anton was born on January 15, 1864, in Raab/Gyorsziget, Hungary and died in 1930. David (Donat) was born on November 14, 1867, in Raab/Gyorsziget, Hungary and died in 1916 in Berlin.

29 Brandenburgisches Landeshauptarchiv, 30 Berlin C, Tit. 74, Th. 777, Akt. 18; October 18, 1897. 
traveling with their seasonal plays into the surrounding suburbs and provinces.

As in the world of Jewish circus families, team-work, family and the collective were important themes in the realm of Jargon theaters. The Gebrïder Herrnfeld Theater was a family enterprise that included the two brothers and their wives, as well as two acting sisters and their mother. Since early childhood Anton and Donat Herrnfeld were part of a family team: they never left the bosom of their family to seek their fortune as individual actors outside of the milieu. Their strong sense of family responsibility resonated throughout their subsequent careers. Their family ethics resonated in how they organized their entertainment enterprise, how they related to their audiences, and in the content of their plays.

Despite the prominent roles of the two director/actors as the "front men" of their shows, they never openly questioned the solidarity among members of the family, which as a concept and a reality represented one of the central beliefs of their existence. It is symptomatic of the self-understanding of all family members that even after their spectacular rise from rags to riches, the mother of Anton and Donat Herrnfeld did not cease to work at the family-owned restaurant in their established theater house. ${ }^{30}$ Just like German-Jewish circus families, the Herrnfelds were very reluctant to give up what they thought to be key positions within the entertainment enterprise. Egon Jameson, a nephew of the Herrnfeld brothers, recalls that family members not only formed the core of the acting crew, they also manned the box office and controlled the management of this highly successful enterprise.

As in circus entertainment, Anton and Donat Hermfeld had total control over the writing, production and performance of their plays. By both authoring and performing their own shows, the brothers struck a close bond with their audiences:

Really only the names Anton and Donat would catch one's attention as directors,

30 Jameson, Spree-Athen, 62. 
authors, producers and leading men. There were of course other actors and actresses employed in the theater, but they were also Herrnfelds -- as for example the sister of A \& $\mathrm{D}$ (my mother) and another sister of A \& D. And the wives of A and D sat interchangeably at the advance ticket office and watched over the golden coins, which they transported to their home during inconspicuous moments to be stored in safes. ${ }^{31}$

The family relations and organization of the Herrnfeld siblings resembled those of GermanJewish circuses: clannishness was combined with great sensitivity to financial opportunities and popular demand. The Herrnfelds nurtured private relationships with Gentile and Jewish actors outside of the realm of Jargon entertainment or the "milieu" of Jewish popular culture. They entertained friendships with well-known individuals such as the exceptional actor Albert Bassermann, the theater "wizard" Max Reinhardt, and the popular composer of fashionable Berlin operettas, Paul Linke. ${ }^{32}$ They met these individuals at private and public occasions, and they spent their family vacation with Gentile and Jewish family friends. Their friendship with Martin Bendix ("Der Urkomische"), one of Berlin's greatest Gentile comedians, is just one among many such relationships. Many, but certainly not all, of the Hermfeld family's friends were Jews. In their personal relations the Herrnfelds seem to have chosen their friends according to their personal liking and their professional appreciation of talent. It was their professional ethos that factored more prominently in their social relations than their ethnic identity. The Herrnfeld brothers formed friendships on the bases of common interests and professional relations beyond the scope of their ethnic group. Unlike circus entertainers, who did not develop intimate relations with their Gentile neighbors or colleagues, even when they had the opportunity, the social habits of Jargon theater entertainers were not confined to one specific milieu only. They were well-acquainted with many movers and doers of the Berlin theater scene and did not lack the confidence or social skills to move smoothly in these circles.

$31 \quad$ Ibid., 62. 


\section{Social Composition of the Audiences}

It is important to supplement the preceding discussion of intra- and extra-family relations among Jargon theater performers with an analysis of the social composition of their audiences. Hence our focus shifts from the performers to their audiences. Who exactly attended Jargon theaters? The social composition of audiences has always been a difficult subject in academic writing for any form of public entertainment. Surprisingly, Jargon theaters left an unusual quantity of information. The daily press provided informed reviews of the theaters' latest premiers and shows. The Prussian theater police regularly supervised them and kept files on every major and minor protagonist in this form of live entertainment. Lastly, these theaters were a target of caricature and ridicule in contemporary popular culture, be it in the plays of rival theaters or in popular poetry and songs. These references in popular culture indicate the widespread knowledge and popularity of Jargon theaters among contemporaries.

Until 1918, the Prussian theater police wanted to know exactly who visited the capital's theaters. Following the "Polizei-Verordnung vom 10. Juni 1851," the theater police sent agents to virtually each theater, circus, cabaret or variety performance, to make sure that the script had not been altered from the approved and censored version. ${ }^{33}$ Preformulated questionnaires provided a separate rubric under which public responses were to be reported. Special investigations were conducted on specific occasions, such as jubilee celebration premieres. These accounts are invaluable for analyzing the reception of German high- and popular culture -- and not only in the Imperial period. During the Weimar years, when a proactive censorship of plays and press was officially abolished, the

32 Ibid., 63.

33 The very first paragraph of this regulation stated that it was forbidden to mount any theater production without the explicit consent of Berlin's theater police. Brandenburgisches Landeshauptarchiv, 30 Berlin C, Tit. 74, Th. 154, Akt. 1. 
theater police did not cease to collect data on individuals - both more and less prominent and they continued to visit performances at least sporadically. They did stop, however, systematically collecting scripts of theater and screen performances. The year 1919 represented the transition year for this attempt at deregulation. To assume, however, that censorship simply ceased to exist after 1918 is a too optimistic view of Weimar and its policing. ${ }^{34}$

In 1901, an inquiry about the Gebrüder Herrnfeld Theater by the Königliche Landesgericht II. provided the first reliable information on the spectatorship of Jargon theater entertainment in its formative years. Alarmed by the double contract of a clerk employed by the Landesgericht -- the individual in question also worked as a musician in the orchestra of the Herrnfeld theater -- court officials requested detailed information about the social and moral standing of this apparently dubious site of popular amusement. The response of the theater police might seem surprising, in light of their reputation as painstakingly strict and authoritarian executors of Prussian authority:

The theater of the brothers Hermfeld ranks as second-class, but it has a good reputation and is frequented by all segments of society. Mainly peaceful Jewish burghers visit it;

${ }^{34}$ Compare for example the secret letter of Berlin's police president von Glasenapp to both the minister of the interior and the minister for science, culture and education, written on July 27, 1920: The opinion of the Theater Council which underlies their response to the attached, that the police decree of June 27, 1919 was made with a view to turning the freedoms gained by the lifting of the censorship laws into their contrary, is completely unacceptable. [...] By removing all stipulations which are no longer in force or antiquated from the original decree, especially those which provide for the examination of all performances, the new decree limits itself to imposing an obligation to advertise for all events, except those which are licensed under articles 32 and 33 of the G.O. and whose schedule is publicly displayed, and to making supervision of all spectacles possible through the dispatch of government officers." Brandenburgisches Landeshauptarchiv, 30 Berlin C, Tit. 74, Th. 154, Akt. 31/32. 
and thus one cannot lodge any complaints about disturbances. No reservations. ${ }^{35}$

From this report one can determine that in 1902, although the Herrnfelds did not yet own their own house, and although their performances were still a mixture between variety show and one-act theater, they already attracted a predominantly middle-class audience. Not even the police viewed the performances at the Hermfeld theater as subversive.

Press coverage of the Gebriider Hermfeld Theater at the turn of the century supported these conclusions. In August 1900, the daily Berliner Lokal-Anzeiger pointed out that the Hermfeld theater had become increasingly elegant. ${ }^{36}$ The Hermfelds seemed eager to adjust their interior decor to their more established audience. They did away with tables and individual chairs, in order to cast off the casual ambiance so common in variety entertainment. They ceased to serve beverages and drinks during the performance and made the stage the main attraction of their establishment. The new layout began to resemble a classical theater in almost every detail. In successive years the Hermfeld theater underwent several further logistical and architectural changes, before in 1906 it settled in still more fashionable premises in the Kommandantenstrasse 57, in a building that was able to host 800 spectators. ${ }^{37}$ Each time the Hermfelds moved into a more upscale neighborhood, they found larger and more lavish premises and enforced a more highbrow dress code.

Yet another indication of the social composition of the Herrnfeld audiences is provided by the content of the plays. The productions of the Hermfelds amused their audiences primarily by mimicking "serious" plays, by ridiculing the sincerity and didacticism of the latter. The success of these parodies relied heavily on their timing and coordination with current theater productions in Berlin, and on the audiences being well acquainted with the "classical cultural canon." Although classical German drama and

35 Brandenburgisches Landeshauptarchiv, 30 Berlin C, Tit. 74, Akt. 80, July 7, 1901. Brandenburgisches Landeshauptarchiv, 30 Berlin C, Tit. 74, Th. 777, Akt. 65, Berliner Lokal-Anzeiger, August 8, 1900.

37 After 1933, this building was to host the performances of the Jüdische Kulturbund. 
Jargon theater ranked quite differently in official esteem, they nevertheless drew similar crowds. To understand many of the jokes at the Herrnfeld theater, one had to be intimately familiar with the content and protagonists of the "legitimate" theater scene. This congruence in spectatorship was by no means mere coincidence. Jargon theaters were part of a middleclass subculture that continually imitated, challenged, and informed the hegemonic cultural canon in Germany.

Only by taking into account major trends in modern mainstream drama can one fully understand the rapid rise in popularity of Jargon theaters after the turn of the century. It was not the segregation from other trends in the performing arts that led to the success of Jargon theater, but the latter's conscious willingness to embrace and integrate itself into those trends. Naturalism, with its passionate search for "authenticity" and its fascination with everyday life, particularly impressed protagonists in Jargon entertainment. Although lacking the same degree of pathos, Jargon theater nevertheless joined the search for the heroic in the profane, so typical of naturalistic drama. Jargon theater could only establish its following because an appreciation for local dialects and "unheroic" sets and motifs became acceptable to larger theater audiences as a result of the efforts of the naturalistic movement. ${ }^{38}$ Naturalistic drama's claim to reflect reality and truth was a political move against the hegemony of court theaters and their traditional aesthetics. It was meant to give voice to the growing demand among the German middle classes to have their lives and concerns reflected on stage. Their spokesman Otto Brahm, one of the founding figures of Die freie Bühne, made his famous declaration, "At the Beginning," (Zum Beginn) where he laid out the framework of naturalistic drama that later became one of the most influential movements in German drama:

Modern art, where it has developed its most vital shoots, has put down roots in the ground of naturalism. It focuses on the recognition of the natural forces of existence, obeying a deeper calling of these days, and with reckless desire for truth shows us the

38 Freydank, Theater in Berlin, 326- 340. 
world as it is. ${ }^{39}$

Not surprisingly, however, neither the productions of Otto Brahm in the Deutsche Theater nor the Hermfeld theater directly mirrored social reality. Both staged highly stylized performances of their specific vision of German society. Both were unified in their attempt to cater to the middle-class audiences. More so than the Deutsche Theater, the Gebrüder Herrnfeld Theater approximated the Volkstheater concept that reformers of German drama had always called for. Lacking an educational goal, however, it never managed officially to gain this status.

In addition to naturalistic drama, the Hermfeld's turned to fashionable French comedies, which were the staple of many popular theaters at the time. When Jargon theaters introduced an ethnic touch to the quickly- paced performances of French comedies, they greatly enhanced their overall appeal, even though theater critics remarked ironically upon the Herrnfeld plagiarisms:

Goethe once said: "the hours, like sisters, are similar, but none equals the other completely." Much the same is true of the farces of the Hermfeld brothers and the ones at the Residenztheater. It seems to us, however, that the latter has not remained without influence on the program of the former. The adultery farces of the Blumenstraße that appear in the Kommandantenstraße seem almost to be translated from a Parisian into German- (or Austrian-) Jewish milieu. ${ }^{40}$

The brothers Herrnfeld had begun a trend that led to the establishment of a new genre of popular live entertainment. Jargon theaters were perceived as an established and acceptable form of live entertainment, suitable for the amusement of the entire family. Men and women attended "their" theater as regulars, and tourists visiting Berlin sought these establishments as an indispensable part of their urban experience. In the pre-war period

39 Otto Brahm, "Zum Beginn." in Jürgen Schütte und Peter Sprengel, eds., Die Berliner Moderne 1885-1914 (Stuttgart, 1993), 192.

40 Brandenburgisches Landeshauptarchiv, 30 Berlin C, Tit. 74, Th. 779, Akt. 141, Deutsche 
Jargon theaters, were sites of middle-class sociability without ever shedding their ambivalent status in Berlin's cultural scene. They were hybrid realms of Gentile and Jewish intimacy in which each faction of society experienced and appreciated the other's presence. Unlike other theaters which provided their audiences with a public sphere in which the spectator felt the shortcomings and blessings of an urban anonymity, Jargon theater presented the illusion of a family atmosphere in which social and artistic predictability radiated from the stage.

Until the First World War, Jargon theaters were able to fill a gap in Berlin's theater scene. Drawing upon various dramatic traditions, they entertained those middle-class audiences that appreciated "folksy" theater. But Jargon theaters also catered to ethnically mixed audiences. It was this open and most-acknowledged coexistence of Gentiles and Jews that was one of the unique and appreciated features of Jargon entertainment. This partial integration of two factions of society -- the one seeking mainly familiarity, the other more interested to come into proximity with unfamiliar social groups -- is particularly striking in light of the continuing discrimination Jews encountered in other spheres, such as the military, the bureaucracy and the political realm.

The success of the Herrnfelds did not go unnoticed in the world of theater and entertainment. Popular theaters such as the Folies Caprice tried to copy the brothers Herrnfeld in almost every detail of their performance, presentation and publicity, and they drew roughly similar crowds. Felix Berg, a student of the famous Victor Baranowsky, was the first to alter the artistic profile of the former Scala- Theater at the Linienstraße 132 to stage "Budapester Possentheater." Just like the Herrnfelds the Folies Caprice originated in popular entertainment and had even fewer roots in the Yiddish milieu of Berlin. In 1905, Budapester theater à la Herrnfeld was considered a safe investment in the business world, and Felix Berg, the founding father of the Folies Caprice, was able to amass sufficient support, totalling 135,000 Marks. This sum is particularly impressive, when one considers

Allgemeine Zeitung, October 8, 1912. 
the great risk investors in the entertainment industry generally faced, an industry in which theaters mushroomed out of nothing only to collapse after one or two seasons. ${ }^{41}$

Berlin's theater police and local press commented on the coexistence of Jewish and Gentile middle-class audiences in the Folies Caprice. The Folies Caprice attracted slightly less well-off audiences than the Hermfeld theater. They were allowed to bring their own food, and enjoyed the cruder nature of the humor at the Folies Caprice, a sure sign that the latter aimed at a less exclusive spectrum of society. ${ }^{42}$ Even in 1921 , when the Herrnfeld theater had already closed its doors, never to regain its former status during the Weimar years, the same middle-class audiences stayed loyal to the Folies Caprice, as in the prime days of Jargon entertainment before the war:

"The audience is mostly bourgeois. One can not find anyone from the demimonde, no monocle gentry which commits burglaries at night, or those rotting Messalines from the Kurfürstendamm sitting in the parquet of the theater boxes. Only honest burghers and their wives come to take their minds off the petty as well as the greater worries of everyday-life." 43

41 Unlike the Herrnfeld theater, however, the Folies Caprice did not remain in the hands of one director over the entire course of its existence. In many cases continuity among the actors was greater than among the directors. The latter even recruited former Herrnfeld actors in order to guarantee the continuation of their success. The lead man Ferdinand Grünecker, who began his career at the Herrnfeld theater and later switched to the Folies Caprice, was just one example for this trend.

42 "The whole Mischpoche [family] is assembled here. There is intimate contact of course between stage and audience. Ham sandwiches, brought from home, are munched with great delight. Once the curtain rises, one takes delight in the knowledge of the Loschen kendesch [the well-known language]. .... The audience feels at home. Actors and audience share the same speech habits, gestures and expressions. ... The audience, which sometimes comes all the way from the West-end, gets its money's worth. And it relishes the Jewish show." Allgemeine Zeitung des Judentums 77 (1913), 286.

43 Brandenburgisches Landeshauptarchiv, 30 Berlin C, Tit. 74, Th. 849, Akt. 2, Große Glocke, April 4, 1921. 
Historians have emphasized that Gentiles and Jews refrained from sharing intimate relations, even though they did interact professionally. It is generally assumed that Jews experienced their Jewish identity only by retreating to their specific milieu, be it at a family gathering, while participating at a Jewish sports association, or as members of one of the many Jewish educational institutions such as the Lehrhäuser. Even the cultural realm, often considered the only realm where Gentiles and Jews could potentially meet on equal grounds, was contested. The tighter the grip of the old elites on institutions involved in cultural production, the more difficulties Jews faced. Against this backdrop, the coexistence of Gentiles and Jews in a theater whose main attraction was the presentation of Jewish identities in German everyday life is all the more significant. In Jargon theaters, the Jewish middle class negotiated their ethnic origins in and through the presence of Gentiles. 


\section{Chapter 7 Artists and Audiences}

In the public's eye, Jargon theaters could not distance themselves completely from their origins in variety entertainment, despite their increasingly upscale locations and their middle-class audiences. Several factors were responsible for this continuing exclusion from the "legitimate" cultural canon. First, the organization of Jargon theaters did not conform to the expectations of classical drama, which celebrated individualism and artistic flexibility among actors and encouraged a division of labor between actors, directors, authors and management. Second, the spontaneous and interactive quality of Jargon entertainment emphasized an oral and not a written dramatic tradition. By contrast, the classical canon held a great respect for the authenticity of the written word and the author's intentions: any spontaneous alteration of script and performance in response to the audience's reaction was undesirable. As the Herrnfeld siblings translated the experiences of their formative years in variety entertainment into their own performances, the same experiences hindered these performers from operating and performing according to the rules of classical theater. The Herrnfelds' childhood years as variety entertainers made it impossible for them to gain the status of "respectable" actors in the realm of "legitimate" culture. Their lack of formal education and their adherence to management and acting practices more common to variety theater were reinforced by their "ethnic" vision of family, by their desire for economic independence, and by their specific kind of humor. As were variety theaters, Jargon entertainment was stigmatized as uncultivated; moreover, it allegedly exploited and promoted mass cultural products. No director of Jargon theater was ever able to cast off the reputation of a "parvenu" in Berlin's established cultural scene. This gap -- between a negative public ascription and simultaneous economic success - represented a neverending dilemma for most Jargon theater performers: Although they aspired to be acknowledged as actors, they were more typically viewed as "merely" comedians. 


\section{The "Family" in Jargon Theaters}

Family was a recurring theme in the realm of Jargon entertainment and was in large measure responsible for the particularly intimate relationship between Jargon entertainers and their spectators. The Herrnfeld theater was not only a family enterprise that presented family life on stage; even audiences and the performers-directors in the Hermfeld theater related in a familial way. Berlin's daily press continued to stress the unique nature of this relationship between audiences and performers at the Gebrïder Herrnfeld Theater. In 1911 , on the occasion of the twentieth jubilee of the Hermfelds in Berlin, the Berliner Börsen-Courier, for example, explicitly compared the premieres at the Herrnfeld theater with a family gathering, a comparison that casts new light on established concepts of the public sphere. Although the theater was generally considered a public area -- visitors dressed to the hilt, as they would not have done at home -- its spectatorship, performance and atmosphere were highly predictable and in many ways familiar to everybody in the audience. Spectators knew each other and habitually met friends and acquaintances at the performances. Some came as members of middle-class associations, paying regular visits to a theater that provided them a forum to socialize and relax. Despite the apparent skepticism of intellectuals mentioned earlier, none of the spectators seems to have been embarrassed to be seen at the Gebrüder Herrnfeld Theater. Although its performances were not considered "high culture" or of any artistic value, its social importance was considerable and openly acknowledged, providing one of the most intimate forums of Gentile-Jewish encounters. Members of the Jewish middle class may have felt awkward upon entering the private homes and participating at the family gatherings of their Gentile neighbors, as Marion Kaplan has argued; but they did not shy away from a search for intimacy and amicable relations at the highly stylized, "invented" family gatherings of 
Jargon theaters. It is this familial atmosphere that permeates the following critique in the Berliner Börsen-Courier in 1911:

A jubilee celebration at the Herrnfeld theater can naturally be celebrated with quite a different verve than one at any other theater. Where plays of different genres, classical and modern works of many different poets are presented by many different actors, actors and director rank second behind the task at hand. How different it is at the Herrnfeld theater. Directors and audience form a family, a close unit, behind which the play fades in importance. For twenty years the authors have been the same; since the very first day, they have also been the leading men. The types of plays remain the same and the audience, the premiere audience, are regulars who swear by their familiar authors. Actors and directors are one personality, or rather one twin personality. Yesterday's jubilee celebrating the past twenty years and the entry into the twenty-first theater year thus has been marked by a truly gay family atmosphere. The old regulars of the house, associations, business partners have sent large wreaths and bouquets with proud dedications. [T] he directors in turn gave all members beautiful garlands with warm dedications, and for the stage veterans they had arranged for splendid golden framed diplomas, which had an allegorical figure and silvery portraits of the directors above and, in the text in rich ornamental lettering, a heart-warming note for each individual. ${ }^{44}$

Neither on nor off the stage did the Herrnfeld brothers act according to the rules of "legitimate culture." By writing, directing and performing their own plays, and by freely integrating material, concepts, jokes, and characters from other plays and authors, they constantly transgressed the codes of conduct that constituted bourgeois work ethic. Their plagiarism and their egocentrism conflicted with the classical theater tradition. Theater critics had long disapproved of a lack of division of labor between actors and author. As late as 1913 the critic Theodor Tagger, writing for Die Schaubuihne, rejected the play "Saul" by the actor Josef Kainz on the basis that it was too centered around its main characters. According to Tagger, Kainz was too concerned with the actor. Making a more general argument Tagger concluded that "the poet tries to invent a part of life or to delineate

44 Brandenburgisches Landeshauptarchiv, 30 Berlin C, Tit. 74, Th. 779, Akt. 105, Berliner Börsen-Courier, August 4, 1911. 
the history of fate .... The actor, in contrast, gives us a character and wants to center life around him." ${ }^{45}$ This critique is symptomatic of the prevailing attitude among many of those involved in classical theater at the time. In the ethos of classical theater, the author's intention was meant to dominate the production of a play; the actor was the medium through which the author's vision came to life. The actor's interpretation of his role was circumscribed by the interpretative boundaries established by the poet. Thus the vision of Shakespeare, Schiller, and Lessing still dominated and informed the acting of mimes such as Josef Kainz, Alexander Moissi, and Alfred Bassermann. Although these were famous actors, acclaimed for their interpretative skills and stage presence, they had to act within the contraints laid down by the author. Because they wrote, directed, and performed their own plays exclusively, the Herrnfelds did not fit the profile of "serious" actors.

The Gebrïder Herrnfeld Theater also cultivated a specific form of management that was in part inspired by the brothers' formative years in variety entertainment and in part by their ethnic identity. The Herrnfelds introduced a family and business ethos, which could be found predominantly among Jewish live entertainers in circuses and variety theaters, into a genre that demanded inclusion into the classical canon of bourgeois theater. The Herrnfelds transformed their particularity into a universal idea. For middle-class morals and the Jewish community, moreover, the family was both a social reality and a symbol: on stage it may have been Schein (appearance), but in the theater it was Sein (reality). ${ }^{46}$ In this context the "family" represented simultaneously a fixed star within the bourgeois universe

45 Theodor Tagger, "Der Schauspieler als Autor," in Die Schaubühne 9, no. 2 (1913), 806. Reference is made to one of the most prominent debates among contemporary actors and directors: The relationship between appearance and reality in modern acting. This debate can be traced as far back as Denis Diderot and his essay, "Paradoxe sur le Comédien," published first after his death in Denis Diderot, Mémoires, correspondance et ouvrages inédits vol. 4 (Paris, 1830). Diderot argued that to be a good actor it was imperative to retain an emotional distance from the character role. Emotions had to appear authentic; they did not have to be authentic. This highly influential essay resonated widely among 
and an expression of ethnic difference. Both dimensions were instrumental to the widespread appeal of Jargon theaters among Gentile and Jewish middle-classes. ${ }^{47}$

\section{Bildung and Jargon Theater Entertainment}

Variety artists and acrobats conceived of their lack of formal education as an important constraint and a handicap in their attempt to find respectability among middle-class audiences. Numerous contemporaries, acrobats, comedians, writers, and journalists took part in an ongoing controversy about how to improve the image of variety entertainment long after it had established a mass appeal. These debates began in the first decade of the twentieth century and continued until the final years of the Weimar Republic. The quest for education and self-formation was meant to enhance the social status of the performer and, by extension, that of the profession as a whole. In many ways this debate was a symptom of the "growing pains" of a young industry involved in the process of professionalization and a struggle for social acceptance.

The flourishing entertainment industry was eager to be recognized as an artistic endeavor. Directors, managers and agents as well as performers argued that selfimprovement of the performers would lead to their inclusion in society at large. This appeal is remarkably similar to those appeals for assimilation that the German-Jewish elites directed at their respective communities in the late eighteenth and early nineteenth centuries. These appeals had an identical rhetoric in their thrust and emphasis, for in both cases emancipation in the widest sense was the ultimate goal of those who previously had been marginalized. Both communities -- variety performers and German Jews -- confronted

theoreticians of modern drama, such as Konstantin Stanislavski for example.

47 On the bourgeois family ethos and its social reality, see Gunilla-Frederike Budde, Auf dem Weg ins Bürgerleben: Kindheit und Erziehung in deutschen und englischen Bürgerfamilien 
demands that questioned their overall existence and did not necessarily correspond to their actual social situations. The spokesmen of both communities reacted with incessant appeals for self-improvement and drastic changes in life-style and orientation. However, their demands were exceedingly difficult to translate into reality. ${ }^{48}$ It was virtually impossible for variety artists to harmonize their constant mobility with the requirements of a society that considered migration to be a threat. In the past, both social groups, Jews and performers, had functioned as the ideal-typical "stranger" (a concept derived from Georg Simmel); they were unable to break free of their assigned roles because those roles defined the boundaries between insiders and outsiders. ${ }^{49}$ At the turn of the twentieth century, variety entertainers nevertheless felt that the time was ripe for fundamental changes in these traditional patterns.

The following assessment of this situation appeared in Der Artist, the conservative journal of the profession that was read and supported by the directors of circuses, revue and cabaret theaters as well as by acrobats and actors who did not belong to the union of performers (IAL). The passage casts light on the sincerity and earnestness of professional entertainers who were deliberating ways to find inclusion into society at large:

These artists have to grow and develop in their profession [Stand]. This is, first of all, a matter of achieving a certain level of education. Education liberates, and knowledge is power. Every artist should take this to heart. Not many heed this, though. I know many famous artists whose youngest offspring does not even receive elementary education,

(Göttingen, 1994); Reinhard Sieder, Sozialgeschichte der Familie (Frankfurt a. M., 1987).

48 See, for example, William Berol in Der Artist no. 1206, March 12, 1908, documenta artistica collection in the Märkisches Museum Berlin. For a discussion of Bildung as a vehicle for emancipation and integration, see George L. Mosse, Jüdische Intellektuelle in Deutschland (Frankfurt a. M., 1992); Aleida Assmann, Arbeit am nationalen Gedächtnis. Eine kurze Geschichte der deutschen Bildungsidee (Frankfurt a. M., 1993); Shulamit Volkov, "The Ambivalence of Bildung," in Klaus L. Berghahn, ed., The German-Jewish Dialogue Reconsidered: A Symposium in Honor of George L. Mosse, (Frankfurt a. M., 1996), 81-97.

49 Georg Simmel, On Individuality and Social Forms (Chicago, 1971), 144. 
despite government regulation and mandatory school attendance..$^{50}$

Professional comedians and acrobats were aware that the commercial aspect of their profession was an essential feature of their existence and had to be reconciled with the "higher" goals of education. They were tom between aspiring to spiritual merits and the demands of the market. This tension is reflected in the following passage (1911) in which a performer is asked to master one of life's most demanding feats:

We should set ourselves great goals, like religion, poetry, philosophy, science, art, music, languages and work, altruism, but also focus on eliminating bad influences. We should educate ourselves as businessmen, because that is essential to our survival. He who works in the real world and lives in the ideal world has truly achieved perfection. ${ }^{51}$

Discussions about the "higher interests of art" took place within all forms of popular culture at the turn of the century. They were part of a power struggle in which new forms of popular culture such as variety theater challenged the claim of social elites to define the content of culture. Performers continuously thought about ways to improve their social standing by simultaneously claiming to be recognized as artists and by responding to the educational demands of bourgeois society. Compared to other entertainers, performers in Jargon theater hardly ever expressed their concerns about their cultural status in public. These performers nevertheless became objects of frequent debates led by the country's leading theater critics.

Again it was the lack of formal education among Jargon entertainers that fueled the contempt of eminent theater critics such as Alfred Döblin, Siegfried Jacobsohn or Alfred Kerr. These intellectuals thought that culture should aspire to aesthetic and spiritual excellence, encompassing the highest achievements of society. Such an understanding of

so Victor Happrich, Der Artist no. 1206, March 12, 1908; documenta artistica collection in the Märkisches Museum Berlin.

51 J. Morie, "Gedanken eines Artisten zum Thema 'Veredelung des Varietés'," Das Programm no. 459, 1911; documenta artistica collection in the Märkisches Museum Berlin. 
"culture," however, was elitist by definition and tended to exclude popular culture from its canon. This understanding contrasts sharply with the definition of "culture" accepted by most cultural anthropologists today, who conceive of it as the sum of symbols and practices common to the majority of society. But these intellectuals' aversion to mass consumerism was not simply dated or eccentric. Rather, it reflected a widespread disdain for mass- and consumer culture among the educated middle-classes, even though such disdain did not hinder most German burghers from actively consuming this very culture. ${ }^{52}$

The significance of this elitist critique of popular culture can hardly be overemphasized. The First World War and its aftermath had heightened the selfconsciousness among intellectuals on the left and on the right who became extremely hostile towards the commercialization of culture. The mass consumption of cultural objects and practices endangered the social and economic standing of these intellectuals in German society. They bemoaned the intellectual vacuum that supposedly had turned a society governed by a respect for learning into a society of blind and manipulated consumers. They saw the intellectual being turned into a pariah, always on the verge of being marginalized and impoverished. Many writers and poets had hoped that "the masses" would turn to the "intellectual" for guidance in their daily struggle for knowledge and stimulation. The tension between this lofty dream and the social reality of Weimar Germany tainted the views of many intellectuals with regard to popular Jewish theater; hence their critique

52 It was this fear that made Alfred Döblin lament the role of the intellectual in the post-war period. His was a call for action in times of distress and disorientation: "There are voices that say the position of the intellectual is hopeless; he can achieve nothing of importance in the state; the great driving forces of industry, technology and commerce are omnipotent. Against these forces, no idea of consequence can thrive; the writer and the poet will soon be lackeys, decor, ornaments for the festivals of the parvenus." Alfred Döblin, "The Writer and the State," in Anton Kaes, Martin Jay, and Edward Dimenberg, eds, The Weimar Republic Sourcebook (Berkeley, CA, 1995), 288-9. First published as "Der Schriftsteller und der Staat," Die Glocke 7, no. 7 (March 16, 1921), 177-182, and no. 8 (May 23, 1921), 207-211. 
should be handled with caution. They were often made by a segment of society greatly alarmed by the erosion of its own social status.

In 1916, when Donat Herrnfeld died after illness, the obituary by Siegfried Jacobsohn (1881-1926) reflected the traditional bias of a bourgeois critic. Jacobsohn mourned the death of Donat Hermfeld as a great loss for the theater scene in Berlin. Yet he interpreted Hermfeld's dedication to Jargon theater as a tragic waste of talent that was irreversable with Donat Herrnfeld's death. He was convinced that "whoever has heard him speak High German for three scenes knows that he would have been a first-class addition to any first-rate theater." ${ }^{53}$ Jacobsohn continued his obituary by deploring Donat Hermfeld's "lack of confidence in his own power," and he criticized Herrnfeld's alleged belief that "his strength came from his genre [Jargon theater]." 54 Jacobsohn was convinced that it would have required only minimal effort for Donat Herrnfeld to have risen above his notorious role as Isidor Blumentopf to play the part of the "classical Jew" Shylock or Nathan.

The increasing conflicts between East and West -- between eastern European immigrants and the established Jewish community in Germany -- may have informed Jacobsohn's assessment. During the war, when assimilated German Jews were increasingly considered to be disloyal and lacking in devotion to the national cause, when German Jews saw their eastern European co-religionists facing expulsion and public rejection, their unease with the projection of ethnic stereotypes was not surprising. In this context, the crude, unheroric performances of the former variety actor Donat Herrnfeld became all the more unsettling to German-Jewish intellectuals such as Kerr, Döblin or Jacobsohn. The latter, in particular, felt it to be very important for a Jewish performer to

${ }^{53}$ In this vein, the Deutsches Bühnen-Jahrbuch remembered Donat Herrnfeld in 1917 as somebody whose "characters did not lack refinement. They were marked by real humor, and would have held their own challenged with higher tasks." Deutsches Bühnen-Jahrbuch 28 (1917), in Landesarchiv Berlin. 
choose his roles carefully. Traditionally, Jews had identified themselves with the "classical" merits, partly because merit as a concept provided an entry into German society, partly because these merits conformed to some of the educational traditions of Judaism. Thus Jacobsohn, as both a Jew and as an intellectual, deplored the fact that Donat Herrnfeld did not stage an intellectualized version of the "tragic" Jew, as defined by the classical theater tradition. To his dismay Donat Herrnfeld was an unheroic hybrid of modern times.

\section{Jargon Theater and Sexuality}

The stage persona Isidor Blumentopf, one of Donat Herrnfeld's most successful roles, did not irritate Siegfried Jacobsohn alone. Whereas Jacobsohn was concerned that Isidor Blumenfeld offered a dubious depiction of a "Jew," other spectators thought the Blumenfeld character to be sexually offensive. More than a decade before Jacobsohn's obituary, the Prussian theater police received one of the few surviving public complaints about the content of the play "Alone at Last!" at the Gebrüder Hermfeld Theater. The dramatic plot of this play revolved around the ill-fated honeymoon of a young Jewish couple -- of which Isidor Blumentopf was the groom -- at a hotel in Germany. Time and again the couple were prevented from finally consummating their marriage because of unforeseen interruptions. Bride and groom lived through a series of adventures and arrests, finally settling their case in court. The open eroticism and tactlessness of a scene that involved Isidor Blumentopf as a leading character elicited immediate protest. In 1902, a letter complaining about the scene in question was addressed to the president of the Berlin police Geheimrath von Jartzky. This letter was written by a spectator named Georg Friedrich Dasbach, a former chaplain and a delegate of the Center Party (Zentrumspartei) in

54 Siegfried Jacobsohn in Die Schaubühne I (1916), 603. 
the Reichstag. ${ }^{55}$ Evidently this letter was preceded by a conversation with von Jartzky. Dasbach took offense at the indirect suggestion in the play that the maid Babett, who had to appear as a witness at court, also worked as a prostitute. More importantly, Dasbach took offense that the "honorable" men present, including the judge, were potential clients of hers. ${ }^{56}$ Interestingly, however, Dasbach did not mention that Blumentopf had addressed the same maid as "Frau Ahlwardt" after she vented her distaste for Jews. This was a notso-subtle slop in the face directed at a well-known antisemite, Hermann Ahlwardt, who had been a prominent member of the Reichstag in the early $1890 \mathrm{~s}^{57}$

Babett: (enters the room) Good God, a Jew!

Blumentopf: Why so surprised --have you never seen a Jew before? Don't worry I will move again - Mrs. Ahlwardt - how mean - ${ }^{58}$

Dasbach let this remark against antisemitism slip and focused instead on the transgression of sexual sensibilities. As a conservative Catholic, Dasbach was offended by open allusions to the double standard of middle-class morals. It is noteworthy that Dasbach did

55 Dasbach (1846-1907) had been chaplain in Trier under Bishop Matthias Eberhard. See Olaf Blaschke, Katholizismus und Antisemitismus im Deutschen Reich (Göttingen, 1997), 138.

56 "In addition to the scenes already mentioned [wrote Dasbach], another scene requires censure, namely where the former maid of the hotel appears in court as a witness and, when asked about her vocation, is at loss for words, thereby insinuating that she is a prostitute. And then the plaintiff Blumentopf required her to state her address, and when she states it, the judge, the jury, the court clerk and the plaintiff pointedly write it down. Such scenes should be eradicated!“ Brandenburgisches Landeshauptarchiv, 30 Berlin C, Tit. 74, Th. 777, Akt. 120, Berlin July 28, 1902.

57 Hermann Ahlwardt (1846-1914), a former director of a gymnasium in Berlin and member of the German Reform Party, was known for his vitriolic speeches in the German Reichstag, where he did not refrain from calling German Jews "predators" and "cholera bacilli." Ahlwardt was arrested several times by the German police. He stood for Germany's rowdy antisemitism. Herman Graml, Modern Antisemitism in Germany (1992), 64.

${ }^{58}$ Landesarchiv Berlin, Pr. Br. Rep. 30 C Berlin 348a. 
not consider his own presence at the Herrnfeld theater as a source of embarrassment; but he wanted only to preserve middle-class morals on the stage of a popular theater. In his view, eroticism, prostitution, and the sex lives of bourgeois couples were not to be ridiculed publicly ${ }^{59}$ The sexual exploitation of working-class women as servants in middle-class homes and institutions was no topic for leisure-time pursuits. The prominent Catholic seems to have found the stage character Isidor Blumentopf distasteful for being indelicate, but not for being Jewish. The sensibilities of spectators were thus injured not by ethnic humor, but by sexual innuendo.

The issue of sexual propriety was not confined to Jargon theaters alone. ${ }^{60}$ It was also ardently contested in the realm of variety theater. Variety artists felt a great need to demonstrate their dedication, discipline and ambition, to fight the reproach that they had deliberately rejected a "normal" life to escape the constraints of bourgeois society. Although eroticism, sexuality and the discussion of gender roles were prominent themes in variety and Jargon entertainment -- indeed, they were largely responsible for its continuing popularity -- most artists de-emphasized these themes in public for two reasons: to avoid transgressing the codified and restrained narrative on sexuality that characterized the classical cultural canon itself, and to avoid offending those who believed that public

59 For a general introduction into the themes of gender and sexuality in modern European societies, see Catherine Gallagher and Thomas Laqueur, eds., The Making of the Modern Body: Sexuality and Society in the Nineteenth Century (Berkeley, CA, 1987);

60 On middle class morals and attitudes towards sexuality and prostitution, see Joan W. Scott and Louise A. Tilly, "Woman's Work and the Family in Nineteenth-Century Europe," in Comparative Studies in Society and History 17 (1975), pp. 36-64; Regina Schulte, Sperrbezirke. Tugendhaftigkeit und Prostitution in der bürgerlichen Welt (Frankfurt a. M., 1979); Karin Walser, Dienstmädchen. Frauenarbeit und Weiblichkeitsbilder um 1900 (Frankfurt a. M., 1985), Peter Gay, Erziehung der Sinne. Sexualität im bürgerlichen Zeitalter (Munich, 1986); Cornelia Usborne, "The New Woman and Generational Conflict. Perceptions of Young Women's sexual Mores in the Weimar Republic," in Mark Roseman, ed., Generations in Conflict (Cambridge, MA, 1995), 1. 
discourse on this subject should remain equally muted. Calls such as the following by the acrobat Erich Kloos were not unusual in the profession:

What I wish for these variety artists is that they continue with their enthusiasm to become educated and through hard work on themselves attain social recognition and thereby raise the social standing of the profession as a whole .... It is the spirit which builds the body. ${ }^{61}$

Self-discipline, hard work, self-formation, the rule of the mind over the body, and a thirst for social acceptance and harmony: all of these cultural codes emanated from the bourgeois discourse throughout the nineteenth century, once identified by the sociologist Max Weber as the very essence of the Protestant ethic. All of these bourgeois virtues very much depended on the oppression of sexual desires and the practice of physical discipline. The professional journal Der Artist, in its attempt to bring respectability into the sphere of popular entertainment and to transform it from Gewerbe to Kunst, failed to acknowledge that popular entertainment capitalized in a significant way on its disreputable aura, which guaranteed mass appeal to its manifold enterprises.

\section{Jargon Theater and Popular Culture}

Jargon theaters were not only part of a subculture; they were also the subject of popular poetry. Whereas the coverage of Jargon theaters in the daily press generally refrained from antisemitic commentary, the references found in popular culture did not exercise the same restraint. That openness suggests the ambivalent position that the Herrnfeld theater occupied in the entertainment scene of Imperial Germany. A particularly revealing example of such commentary was a poem written by A. O. Weber (1905), entitled "The Herrnfeld

61 Erich Kloss, Der Artist no. 1206, March 12, 1908; documenta artistica collection in the Märkisches Museum Berlin. 
Theater." This poem is an exemplary defamation of the two directors Anton and Donat Herrnfeld, and of their reception by the satirical press, as such it demonstrates how humor was always ambivalent in nature, facilitating minorities' inclusion and exclusion from society at large. Often it is difficult to say when one is laughing with or laughing at the other; but this poem demonstrates how this line was crossed, pushed and re-established in Wilhelmine cultural discourse.

Weber's poem deplored the success of the Gebrüder Herrnfeld Theater, but acknowledged that this was not a theater on the margins of society. We learn about the theater's tremendous success among mass audiences, its wide-ranging and aggressive publicity campaigns in the daily press of the capital, and the content of its plays. But two of the most prominent themes of cultural critics emerge in this supposedly humorous depiction of Jargon theater with remarkable clarity: the rejection of parvenus in the cultural realm, and the commercialization of culture. Lastly, the poem sheds light on the social status and reputation of immigrants from Eastern Europe who had come to Germany to seek refuge from discrimination and economic hardship in Russia, Poland and the Baltic states:

The Hermfeld Theater:

To be frank, just another theater;

A fleapit in downtown Berlin!

Two Jewish-German Classics

Imported by way of Vienna

Are tenants there and directors;

Two Jids they are down to the core

But unfortunately no Jews.

The author identified the brothers Herrnfeld as "Two jüdisch-daitsche classics / imported by way of Vienna," implying that their real origins were located much farther east than Vienna. "Jüdisch-daitsch" was a post-emancipatory expression for Yiddish, which was originally used by Eastern European Jews simultaneously to mark their allegiance with German culture and to separate their language from other languages such as Polish or 
Lithuanian. ${ }^{62}$ In 1927/30 the Jüdische Lexikon identified Jüdisch-Deutsch as a term employed by Gentiles to describe Yiddish. ${ }^{63}$ Over centuries, the self-description of Eastern European Jews had given way to their description by Gentiles. One may therefore speculate that the author who deliberately used the pre-emancipatory term "jüdisch-daitsch" was a Gentile.

The poem continued:

They write their own pieces

But Schammes is said to help them

Well, where three such cooks are at work

Every mash must become unpalatable.

The best materials can be pinched,

Where there is no talent for writing,

But when three people start patching

Every piece must be ruined.

And if enough fools can be found

To watch this Jewish nonsense,

And enough noble German newspapers

Come begging for advertising,

And praise those piggish managers for their inserts

Well, no wonder, Herrnfelds pay cash!

A hostility towards the press, often associated with a Jewish sphere of influence - the Mosse or the Ullstein families were only the most prominent examples - permeated this poem. Vile materialism and the anxiety that German audiences were defenseless against an aggressor within the capital's cultural life are the underlying themes of this poem. Unlike Yiddish theater from the Scheunenviertel, the Hermfeld Theater was both critiqued in mainstream newspapers and advertised in these papers during their elaborate publicity

62 Bettina Simon, Jiddische Sprachgeschichte. Versuch einer neuen Grundlegung (Frankfurt a. M., 1988), 52.

${ }^{63}$ G. Herlitz and B Kirschner, eds, Jüdisches Lexikon (Berlin, 1927-1930), 3: 462. 
campaigns, unrivaled in scale and energy. The Herrnfelds were indeed on friendly footing with many critics and reporters, a relationship they pursued with energy and confidence -the same confidence that also permeated the shows of the Hermfeld brothers. Far from being apologetic, they were self-made-men. Modesty and the art of understatement -- these very bourgeois virtues - were alien to them. Instead, they were pleased to display their success and wealth to all of Berlin. Ironically, the poem by A. O. Weber was in its own way another proof of the Hermfeld Theater's importance in the urban landscape of Berlin as well as a testimony to the envy and horror it evoked among certain factions of Berlin's society.

The audience as abtuse as ever, believes the whole charade And laugh in impish delight when Jids Ridicule the Jews so meanly. When a Jew is made the villain Who makes his living with perjury, Every Christian reflects complacently:

You Jews, you deserve each other.

But such a Herrnfeld is not even a Jew, Jid is he, to a T.

The Jid is the greatest enemy of the Jew, Who undermines his honor

Despite all this, even the children of Israel

Come to this temple of German culture

To see how these two poets

Ridicule the Jews.

Sigmund Freud once pointed out that jokes by Jews about Jews were told with a different knowledge and intention than similar jokes told by Gentiles. He pointed out that jokes told by Jews often linked their deficiencies with their talents, which did not allow the listener to 
distance himself from the object of the joke. ${ }^{64}$ Thus a joke could be as much a means of distinction as it could lead to an identification with the object of the joke. The Hernfeld theater provided Berlin with a public stage on which jokes about Jews and their relations with Gentiles and other Jews were made in front of a mixed audience. Whereas Freud assumed that Jewish jokes lost their edge when they were told by Jews, Weber makes a distinction between "Jew" or "Jid" telling the jokes. ${ }^{65}$ Whereas Germany's educated and highly assimilated Jews cracked jokes about Ostjuden, Jews "imported through Vienna" could not easily do the same ("Two Jids they are down to the core / But unfortunately no Jews"). The principal demand of this piece is the complete assimilation of Jews: the transition from "Jid" to "Jew" would rid Germany of this alien eastern European influence. The ambiguous nature of the Herrnfeld brothers and their theater was seen by some Jews and by some Gentiles as despicable. In this vein, the Herrnfelds lacked honor, education, propriety and self-respect at least as defined by Western society.

"But such a Herrnfeld is not even a Jew, Jid is he, to a T." This observation stands in odd opposition to the concept of race employed in the last paragraph of the poem: "But to prostitute your own race / for filthy money." Obviously, both the assimilated German Jude and the non-assimilated Jüd are part of the same "race." The author of the poem, however, seems not to have any difficulties with the conflicting concepts. Race, a biological term, is used in conjunction with demands for assimilation. To this extent, the early nineteenth century (hopes for assimilation) meets the twentieth century (racial distinctiveness) in this poem: contradictory world-views coexist in one voice and the Old World continues within

64 "These are stories created by Jews to address Jewish characteristics. Jokes about Jews cracked by strangers are often brutal farces depicting Jews as comical figures. Jewish jokes by Jews do the same, but they know that the real flaws are connected to their merits. The relationship of oneself to the subject being criticized, created the subjective condition necessary for the joke to succeed." Sigmund Freud, Der Witz und seine Beziehung zum Unterbewussten. Der Humor (Frankfurt a. M., 1992), 14.

65 One may translate "Jude" und "Jüd" with "Jew" and "Jid." 
the new.

If these wizards of advertising

concerned themselves with shoe polish, or opal

Or even old clothes or furniture,

None of this would be of consequence.

But to prostitute your own race

for filthy money

with the aid of the press.

What appeals to the most common circles

should properly disgust the majority,

be they Christian or Jewish; -

-- But everyone attends that theater

that his minds deserves! ${ }^{66}$

By referring to "old pants and furniture," the poem evokes the image of the "assiduous pant-selling youths" (hosenverkaufende Jünglinge) Heinrich von Treitschke used in his notorious attack on the Jews as "Germany's misfortune." ${ }^{67}$ This popular antisemitic stereotype depicted eastern European immigrants and pre-emancipatory Jewry as poor, wandering peddlers, hardly able to make a living without cheating and corrupting their clients. In 1879, Treitschke considered every unassimilated Jews to be a source of danger to the German Volk. In the course of Berlin's antisemitism Controversy -- the Berliner Antisemitismusstreit -- Treitschke's characterization became common currency among greater segments of the German middle-classes. Fifteen years later, although the antisemitic

66 A.D. Weber, Berlin und die Berliner (Berlin, n.d.), 44-46. For original see Appendix 1, page 289.

67 Walter Boehlich, ed., Der Berliner Antisemitismusstreit (Frankfurt a. M., 1965); Steven E. Aschheim, "The Jew Within:' The Myth of 'Judaization' in Germany," in Jehuda Reinharz and Walter Schatzberg ed., The Jewish Response to German Culture: From the Enlightenment to the Second World War (Hanover, NH, 1985), pp. 212-241; Hans Liebeschütz, "Treitschke and Mommsen on Jewry and Judaism," in Leo Baeck Institute Year Book 7 (1962): 153-182. 
parties had lost most of their voters, this rhetoric continued to inform German popular discourse.

\section{Jargon Theater, the First World War}

The Gebrüder Herrnfeld Theater was identified by its enemies and friends as a site where Jews displayed, humored and problematized ethnic difference and the trials and tribulation of Jewish assimilation in the presence of a mixed audience. The self-confident humor of Jargon theaters sometimes even seemed to toy with the sensibilities of its middle-class Gentile and Jewish audiences. These audiences conceived of the Hermfeld Theater as a Volks- and Dialekttheater that presented Jewish types and identities on stage. These highly stylized types drew upon the manifold lives of German and Austrian Jews. The mixture between caricature and realism was the key to the radiant quality of these plays. Walter Turszinsky, one of the most eminent theater critics at the time, pointed to the dual aesthetic quality of these performances. In 1906 he observed that "a good part of our citizens can find their own manners, language expressions, gestures and expressive nuances only in the repertoire pieces of those immigrants. ${ }^{68}$ Simultaneously to experience the foreign and the familiar in an informal but festive setting attracted both Gentiles and Jews to Jargon entertainment. Nevertheless, during the First World War impenetrable boundaries between insiders and outsiders in German society were erected.

After the death of Donat Herrnfeld in 1916, Anton Herrnfeld stopped presenting familiar themes on stage. This deviation from the usual program at the Hermfeld theater was mourned even by a critic writing in the conservative agrarian newspaper, the Deutsche Tageszeitung. This critic deplored the loss of the "ethnic angle" of the Hermfeld plays,

68 Walter Turszinsky, Berliner Theater (Berlin, 1906), Großstadtdokumente vol. 29, 93-99. 
which previously had allowed both Gentiles and Jews to reflect in a relatively unconstrained way on the issue of Jewish identities in German society.

The peculiarity of the Hermfeld-Theater, its comical effort of wanting to be the Yiddish stage of Berlin, unfortunately appears to move to the background. This is at least a cultural loss; those who were more distanced from eastern culture were able here, in the warped mirror of comfortable self-irony, to familiarize themselves with it and take pleasure in a good confident kind of humor that doesn't shy away from self-criticism. ${ }^{69}$

By 1914, the content of the Herrnfeld's acts had been severely restricted, corresponding with the seriousness of the times. ${ }^{70}$ Immediately after the declaration of war against France on 4 August 1914, most popular amusements, be it music halls, cabarets, or Jargon theaters, were forced to close their doors. Jargon theaters were the first theaters to open them again after the initial shock and outrage in the German press had faded. ${ }^{71}$ Jargon theaters quickly adapted to the new public mood and began to stage patriotic one-act plays. These plays generally centered on the extraordinary effort made by Jewish soldiers at the front and the anxiety and patriotic feelings of their families at home. They particularly emphasized the singular nature of the alliance between Germany and Austria-Hungary; many of these plays were set on the German-Austrian border. This shift in content was as much a reflection of the theater directors' and their audiences feelings as it was a product of their desire to meet the new regulations set down by the Prussian censors. During the war, Berlin's theater police were very diligent; they did not let anything slip that could either mock the monarchy or ridicule the war effort. Adultery and most forms of ethnic humor

69 Brandenburgisches Landeshauptarchiv, 30 Berlin C, Tit. 74, Th. 780, Akt. 36, Deutsche Tageszeitung September 16, 1916.

70 Gary D. Stark, "All Quiet on the Home Front," in Frans Coetzee and Marilyn ShevinCoetzee, eds., Authority, Identity and the Social History of the Great War (Providence, RI, 1995), 62.

71 Otto Schneidereit, Berlin wie es singt und lacht. Spaziergänge durch Berlins Operettengeschichte (Berlin, 1973), 179. 
became equally undesirable, leaving little room for any form of humorous entertainment. In August 1914, the German emperor emphatically declared that he would no longer recognize parties, but only Germans, united in the famous Burgfrieden (domestic truce). It was this attempt to unify Germany, however that made its cultural, religious and political diversity painfully apparent. Humorous references to various regional and ethnic identities, originally intended to reinforce a sense of community, now became markers of unacceptable difference in the face of the nationalist consensus. One of the most visible signs for such a change in the acceptance of difference was the German Army's Jewish "enumeration" ("Judenzählung") of November 1916. It was meant to determine whether Jews were shirking their military obligations or were engaged in profiteering, and can certainly be considered a decisive turning point in Jewish-Gentile relations. ${ }^{72}$ Jargon theaters chose to react to the new climate by downplaying the ethnic dimension of their performances. Because Jargon theater directors and performers did their best to adjust their plays and programs to the altered situation, their genre as such became obsolete in the course of the war. Cosmetic changes and changing emphasis could not halt the decline of Jargon entertainment. Once cultural diversity and coexistence were renounced and replaced by a call for conformity in the course of the war, their initial appeal as a popular Jewish theater was lost.

Whereas the Herrnfeld theater gave up altogether in 1916, the Folies Caprice changed its program and made sexuality the dominant theme in its performances; it was thereby able to consolidate its popularity by 1921 . This was a first step to becoming "mainstream" and relinquishing its unique status in Berlin's entertainment scene. As in the founding years of Jargon theaters, complaints were raised about the "obscene" nature of the acts and their corrupting influence on the audiences. Berlin's Verein zur Bekämpfung der öffentlichen Unsittlichkeit E.V. in particular feared that Germany's youth would be

72 Angress, "Judenzählung," 117. 
corrupted by the sexually charged performances of the Folies Caprice. ${ }^{73}$ Although this association's complaint to the Berlin police was received with empathy at the time, the authorities drew up no official sanctions. Neither the theater police nor most theater critics felt that any discrimination against the Folies Caprice could be justified in light of the new liberties other performers took on Germany's more established stages. For example, the daring and openly sexual production of Arthur Schnitzler's Reigen at the Kleine Schauspielhaus especially offended some police officials. ${ }^{74}$ At first sight, this affair resembled the Dasbach affair discussed earlier. Yet, unlike in previous years, no comment on the part of press, police or spectators referred to the Folies Caprice as a popular Jewish theater, or rather a theater focusing on Jewish themes. A contribution to the Neue Berliner Zeitung was typical in failing to allude to the Jewish aspect of such drama. Neither the internal police correspondence nor Berlin's press had refrained from such comments in previous decades. We can assume that not only the sensibilities of these witnesses had changed, but also that the performances themselves had been altered to match these new sensibilities. The earlier quest to paint colorful, mocking, or endearing pictures of Jewish life in Germany had been replaced by mandatory but routine references to common Jewish stereotypes, names or customs.

In the early 1920s, it was mostly open eroticism and sexually charged humor that attracted Berlin's spectators into the Folies Caprice. The rise of antisemitism and the general discomfort with ethnic difference in the post-war crisis politicized any ethnic humor on stage. A public eager to escape political tensions was not attracted to performances that could possibly antagonize the audience. In fact, politics had never attracted large crowds to sites of German entertainment. In order to hold their audiences, Jargon theaters such as the Folies Caprice changed their emphasis: sex alone became their greatest attraction, as it was

73 Brandenburgisches Landeshauptarchiv, 30 Berlin C, Tit. 74, Th. 849, Akt. 4; the author is F. Reuter, April 4, 1921.

74 Brandenburgisches Landeshauptarchiv, 30 Berlin C, Tit. 74, Th. 
in most other forms of popular entertainment of the early Weimar Republic. Neither political nor ethnic humor could be assumed of bringing these audiences together to join in a communal laughter, but sex was always a winning formula. It was this instrumentalization of sexual crudeness that elicited contempt from the conservative press, just as it prompted amusement among liberal journals. In 1921, a writer in the conservative Die Tageszeitung noted:

All those were mistaken who would have believed that even certain Berlin theater owners could not stoop lower into the morass of depravity than they have over the last few weeks. Yesterday I attended a theater performance - I don't want to name the theatre company, well-known and popular for its obscenities - which for anyone with an ounce of decency dwarfed anything presented outside of the outright red-light milieu .... Truly, an incomparable flowering of the arts and culture. Anyone who doubts it is a grumbler (Mucker)!! $!^{75}$

In a handwritten note, the author of this critique, Professor Dr. Brunner, identified the Folies Caprice as one of the main sites of sexually offensive performances. ${ }^{76}$ Whereas Brunner and the conservatives he represented felt that mainstream sexual sensibilities were constantly offended by popular theaters such as the Folies Caprice, others welcomed this taking of liberties as a means to reform public discourse. A contribution to the Neue Berliner Zeitung, for example, did not find anything offensive in the performances of the Folies Caprice. On the contrary, this writer laughed at those philestines who chastized the Folies Caprice for its ribald sexual humor: "Man zwinkert, tuschelt, und lacht, da laut und dort verschämt, aber die deutsche Übermoralgemeinde braucht nicht aus den Kutten zu

75 Brandenburgisches Landeshauptarchiv 30 Berlin C, Tit. 74, Th. 849, Akt. 3, Deutsche Tageszeitung March 4, 1921.

76 "The 'Folies Caprice' has long since developed into the special stage for obscenities, and by virtue of this it possesses a particular attraction. The systematic manner in which indecency organizes its business here is an insult to the authorities, who even today ought to feel obliged to protect decent sexual mores as part of the public order." Brandenburgisches Landeshauptarchiv, 30 Berlin C, Tit. 74, Th. 849, Akt. 1. 
springen. Mit der Erotik versöhnt der unwiderstehliche Humor der Stücke und die in ihrer Art einzige Darstellung." ${ }^{77}$ Conservatives and liberals agreed, however, that the Folies Caprice had evolved into a theater focusing mainly on sexual humor.

Not only sex, but sex and death together proved to be another winning combination in the immediate post-war period. Whereas circus entertainment tried to attract its audiences through Todesartistik, and whereas popular theaters introduced sex shows as their main attraction, some bluntly combined sex and violence. Numerous contemporaries remembered how death, humiliation and drugs fascinated Berliners and dominated the city's popular entertainment scene in the aftermath of the war. ${ }^{78}$ Even the family-oriented Jargon theaters fell victim to this general brutalization of the public sphere. It was not exceptional, for example, that when one scene in a play at the Folies Caprice depicted the separation of a couple, one actor suggested to the other that their unwanted child should be disposed at the knocker's yard. ${ }^{79}$ Increasing poverty, hyperinflation, and the trauma of a lost war had led to the breakdown of bourgeois moral codes that had previously sanctified family life and responsibility of parents for their children. Now, the Folies Carpice not only poked fun at those tottering moral codes; it eventually seemed to endorse things opposite.

\section{Aliens and the German Nation}

Already by the end of 1914 , this new hostility towards ethnic and national differences manifested itself in the realm of live entertainment. One obvious sign of the times was the almost hysterical rejection of foreign names in show business. This phobia was part of a

77 Brandenburgisches Landeshauptarchiv, 30 Berlin C, Tit. 74, Th. 849, Akt. 1; Neue Berliner Zeitung, February 19, 1921.

78 See for example Friedrich Hollaender, Von Kopf bis Fuß (Bonn, 1996), 69.

79 Brandenburgisches Landeshauptarchiv, 30 Berlin C, Tit. 74, Th. 849, Akt.3, Deutsche Tageszeitung, March 4, 1921. 
larger crusades against foreign artists and against any foreign influences, real or imagined, in the style and content of shows. Germans came to distinguish sharply between exotic and alien. Such aggressive protectionism of German culture and society was not confined to the realm of show business, but penetrated all spheres of life. German nationalists intuitively knew how to dwell on the connection between language and social reality. With their stated aim of purifying the German language of "foreign words," they also hope to purify German society of "foreign influences." One of the most ardent advocates of such purification, was the Allgemeine Deutsche Sprachverein -- an association that wanted to rid the German language of any foreign words. The influence of the Sprachverein was evident when Berlin's police president went out of his way in September 1914 to urge his administrators to erase any trace of foreign words (Fremdwörter) from Germany's current vocabulary. ${ }^{80}$ By 1915 , most Germans probably used the term Fremdwort in its most literal meaning: "foreign word."

In 1914/15, it was the Folies Caprice and not the more respectable Herrnfeld theater that first became a thorn in the flesh of self-proclaimed nationalists. Its French name provided ammunition for members of the Sprachverein. The Folies Caprice was singled out to become one of the first theaters to be accused of treason. These debates, however, were not confined to the circles of hard-core fanatics. The presence and influence of foreigners, their culture and language, made the front pages of daily newspapers and professional

80 "Today more than ever there are good reasons to avoid unnecessary foreign words. Enclosed I am humbly sending Your Honor a part of the Germanization-edition of the Allgemeiner deutscher Sprachverein "Die Amtssprache", with the request to supply a copy all civil servants in your department who are drafting official documents; the required number of copies can be ordered from the central bureau. Additional ones can be obtained for returning civil servants at any time, especially after peace has been established." Brandenburgisches Landeshauptarchiv, 30 Berlin C, Tit. 74, Th. 3750, Akt. 43; Berlin, September 25, 1914. 
journals. ${ }^{81}$ On September 27, 1915, the director of the Sprachverein called the police's attention to the continuing internationalism in Berlin's entertainment scene, and demanded that the Folies Caprice change its name:

Monuments of shame - that's what one almost also wants to call those French names of various entertainment establishments that are even today proliferating on Berlin advertising columns. For years Berlin has had a comical theater company, the Folies Caprice. In light of the Xenophilia (Ausländeret) prevalent in the past this is not much of a surprise, except perhaps that an enterprise aiming at fun and humor exhibits such intellectual poverty in the choice of its name. Talmi! Now it has probably dawned on them that this Francophilia is no longer in fashion, and therefore they print their announcements with both words crossed through. ${ }^{82}$

The war provided an opportunity for extreme nationalists to gain an unprecedented influence in the realm of culture and entertainment. Berlin's police authorities, who in the pre-war period were not particularly inclined to suppress Berlin's expanding entertainment industry, found themselves confronted with demands that they could hardly ignore. The existence of many entertainers and theaters was seriously endangered by these changes in public sensibilities. Director Schreiber of the Folies Caprice rightly feared being targeted, and he went out of his way to prove his "innocence" by trying to demonstrate both his good taste and cooperation. ${ }^{83}$

The discussion about foreign names in live entertainment was only the tip of the iceberg. The war was fought in all spheres of popular culture, be it theater, music entertainment, or cabaret. Foreigners, many of whom had lived in Germany for decades and many of whom were often married to German citizens, faced persecution and

81 See for example: "Die Ausländerei auf der deutschen Bühne, zweite Folge, was die Dichter sagen", in Berliner Börsen-Courier January 27, 1915 or "Die Verdeutschung der Artistensprache," in Das Programm, no. 661, December 6, 1914; documenta artistica collection in the Märkisches Museum Berlin.

82 Brandenburgisches Landeshauptarchiv 30 Berlin C, Titel 74, Th. 3750, Akt. 35 and 40.

83 Brandenburgisches Landeshauptarchiv, 30 Berlin C, Tit. 74, Th. 3750, Akt. 43. 
potentially expulsion. The combination of wide-spread paranoia about a fifth column, a sense of cultural superiority, and the need to identify scapegoats responsible for the economic hardship - these factors, especially in combination, made the personal situation of many foreign artists unbearable. Some German entertainers manipulated such contemporary fears for personal gain, turning private envy into a national affair. Performers who in previous years had not found ways to deal with unwelcome competition felt that their time had come to intrigue against former colleagues and friends on the basis of the national cause. This discrimination was encouraged and facilitated by different institutions, and in the end even sanctioned by the Intemationale Artisten Loge E.V. (IAL), the official union of circus, variety and cabaret performers. The union stipulated, for example, that directors could summarily lay off performers who refused to reveal their citizenship. ${ }^{84}$

Many denunciations have survived, testifying to how the First World War could bring out the worst in Germany's citizens. In November 1914, for example, the Berliner Ensemble Musiker Bund, originally founded to form an institutional platform to represent the interest of individual musicians, asked the military authorities in Brandenburg (Oberkommando in den Marken) to remove unwelcome foreign competitors: ${ }^{.5}$

Despite the treatment of our compatriots in the enemy countries, a treatment that is an insult to all cultural decency, in our own country foreigners not only enjoy the greatest liberties, but also work very busily and are sometimes preferred in our occupation, because they substantially undercut prices. For example, the Russian von Spannowsky works in the orchestra at the "Deutsche Theater", the Russian director of music Leiserowitsch at the "Central Hotel", the Russian Lewitsch at the "Rollkrug Kino" in Neukölln, the pianist Robert (Belgian) at the "Lichtspiele Wittelsbach" cinema in Wilmersdorf, Berlinerstrasse 166, the Cellist Liebenbaum (Russian) at the "Amor Lichtspiele" cinema in Wilmersdorf, Uhlandstrasse 81 , and the pianist and harmonium

84 Brandeburgisches Landeshauptarchiv, 30 Berlin C, Titel 74, Th. 3748, Akt. 40. unwelcome competition was unfounded. 
player Melzak (Russian) at the Café A.B.G. Schöneberg, Bambergerstrasse $21{ }^{86}$

The analysis of complaints to Berlin's police from associations or individuals reveals that Russians, far more than the French or British, seem to have offended German artists' national pride. An even closer look reveals that these "Russians" were mostly Russian Jews who had immigrated from Czarist Russia to Germany at the turn of the century. These Jews had successfully lived in Germany for several decades, without becoming a burden to Germany's welfare system. The case of Max Widetzky is representative. Born in Riga, Widetzky came from the pale of settlement, the area with the highest concentration of Russian Jews. Married to a German woman he had lived in Berlin since 1902, he supported himself and his wife working as a singer and composer. Feeling a rising pressure to demonstrate his gratitude towards his second home, he petitioned to entertain wounded German soldiers with his choir for free.$^{87}$ Foreigners, and especially foreign Jews, felt compelled to volunteer their services for the German war effort, hoping that their contribution would prevent them from being expelled to their birth country.

It is difficult to determine whether the German idea of Russia as an Asian, foreign and uncivilized country made Russia's citizens all the more unbearable, or whether it was chiefly antisemitism that found its outlet in the persecution of Russian Jews. For many Germans, the concept of the eastern Jew (Ostjude) combined these two aspects in a threatening way. ${ }^{88}$ Whereas shtetl culture was viewed as an intriguing and amicable form

86 Brandenburgisches Landeshauptarchiv, 30 Berlin C, Titel 74, Th. 3748, Akt. 3; the author was K. Schiementz, Berlin, November 17, 1914.

87 "To demonstrate my patriotic conviction I have founded a choir which has given several concerts at field hospitals for injured warriors." Brandenburgisches Landeshauptarchiv, 30 Berlin C, Titel 74, Th. 3748, Akt. 114, March 3, 1917.

88 For a discussion of the concept of the Ostjude, see Jack Wertheimer, Unwelcome Stranger: East European Jews in Imperial Germany (Oxford, 1987); Steven Aschheim, Brothers and Strangers : East European Jews in German and German-Jewish Conciousness, 1800-1923 (Madison, 1982); Trude Maurer, Ostjuden in Deutschland, 1918-1933 (Hamburg, 1986). 
of rural life in the pre-war period, and thus functioned as an the object of amusement in Jargon theater, its image in the mainstream of German society changed in the course of the war. To be sure, some Jewish intellectuals were about to discover and romanticize their shtetl roots, leading to what was came to be called "the renaissance of Jewish culture" in the Weimar Republic. Nevertheless, as early as the second year of the war, the German public was less generous in its judgment. ${ }^{89}$

The general antipathy towards "enemy aliens" (feindliche Ausländer) soon focused particularly on Jewish immigrants. Jargon theaters as a genre had no place in a society that began to turn inward. The former interest in cultural exchange with neighboring countries had given way to fierce protectionism, and open acts of violence against "aliens." These trends accelerated dramatically in the half-decade after the November revolution of 1918. The mixture of unemployment, inflation, and racial discrimination proved to be explosive. It culminated in 1923 in mob violence and anti-Jewish pogroms in the Berliner Scheunenviertel. ${ }^{90}$ Radical antisemitism was a logical outcome of this development and made it particularly difficult for many Jewish artists to eke out an existence in Germany's orchestras, theaters and cabarets. But it was not only social discrimination that made it

89 The Wintergarten, for example, was under rising pressure to lay off Russian Jews who had constituted a large proportion of its staff. Brandenburgisches Landeshauptarchiv, 30 Berlin C, Titel 74, Th. 3748, Akt. 25.

R. Scholz "Ein unruhiges Jahrzehnt: Lebensmittelunruhen, Massenstreiks und Arbeitslosenkrawalle in Berlin 1914-1923," in M. Gailus, ed., Pöbelexzesse und Volkstumulte in Berlin. Zur Sozialgeschichte der Straße 1830-1980 (Berlin, 1984), 116 ; cited in Detlev J.K. Peukert, The Weimar Republic. The Crisis of Classical Modernity (New York, 1992), 160; for antisemitic violence in post-war Germany, see Donald L.Niewyk, The Jews in Weimar Germany (Barton Rouge, 1980); Till van Rahden, "Ideologie und Gewalt. Neuerscheinungen über den Antisemitismus in der deutschen Geschichte des 19. und frühen 20. Jahrhunderts," in Neue Politische Literatur 41 (1996), pp. 11-29; Richard Bessel, Germany after the First World War (Oxford, 1993), Dirk Schumann, "Der aufgeschobene Bürgerkrieg: Sozialer Protest und Politische Gewalt in Deutschland," in Zeitschrift für Geschichtswissenschaft 44 (1996), pp. 526-544. 
harder for the average Jewish performer to work in the post-war entertainment industry. Germany's entertainment scene was economically and artistically impoverished by the war. Employment opportunities were drastically reduced, not least because Jewish enterprises in particular collapsed in great numbers.

It is symptomatic for the increasing ethnicization of the public sphere that the rightwing newspaper, the Deutsche Zeitung, known for its antisemitic tendencies, celebrated the Palestinian Theater on its tour through Berlin in 1924, but simultaneously castigated Jewish actors such as Elisabeth Bergner or Maria Orska for their claim to be German actors or directors first and foremost:

Coming up shortly, a Palestinian theater company will give a guest performance in Berlin. They perform in Hebrew, thus confessing to their ethnic peculiarity. It is to be welcomed that any pretence is avoided and the artists are aware of their home culture. If Jeßner, Kortner, Elisabeth Bergner, Maria Orska etc., etc., also remembered their Semitic origins, their artistic expression would be purer and more powerful than now, when with carefully-calculated misrepresentation they appear as German artists. At the very most they are German citizens of Judaic faith. The more Berlin's Jewish stage artists profess their allegiance to their race openly, the more valuable their performances become as a contrast to Germanic acting art. ${ }^{91}$

By the 1920s, the extreme right was not the only advocate of an artistic separation of German and Jewish drama. Hybrids such as the Jargon theaters, with their roots in various dramatic traditions and their depictions of Jewish assimilated life, lost much of their appeal among the general public. The attraction of Jargon entertainment faded the moment both Jewish and Gentile Germans began to question assimilation as a goal. In the newly chauvinistic environment after 1916, Jewish assimilated life became more tenuous and problematic among both Gentiles and Jews, and when these theaters appeared to be remnants of a lost world. Ironically, this impoverishment of Berlin's theater scene was

91 Brandenburgisches Landeshauptarchiv 30 Berlin C, Titel 74, Th. 3748, Akt. 179, Deutsche Zeitung Mai 4, 1924. 
completed in an era - "the Golden Twenties" - acclaimed for its creativity, vibrancy and freedom of expression. 


\section{Chapter 8 Aesthetics}

Before the outbreak of the First World War almost all plays at the Herrnfeld theater and the Folies Caprice centered around one single leitmotif: the assimilation of German Jews. Themes such as mixed marriages, religious devotion, dietary laws, Jewish names, economic success, the stigma of the parvenu, education, and relations to Germany's traditional elites were central to these plays. The Jewish family and its immediate environment provided the setting in which these issues were negotiated, ridiculed and contested. Although the Folies Caprice was more direct in language and humor than the more tempered Hermfeld theater, both shared the same concerns. It was one of the main assumptions of all plays produced in these theaters before the war that Jews represented a religious denomination, held together by a shared set of beliefs and practices that did not conflict with their allegiance to the German nation. The Jews who were depicted on the stages of Jargon theaters were not simply seen as Jews but as German citizens of the Jewish faith (deutsche Staatsbürger jüdischen Glaubens). Just like Jewish circus families, Jewish performers in Jargon theaters took pride in their Germanness, but they did not ignore the continuing discrimination against Jews in many spheres of public life. Jargon theaters problematized both the ability and willingness of German Jews to assimilate to middle-class norms and expectations as well as the difficulties experienced by the majority to accept them unconditionally. Jargon theaters were sensitive to current debates in the German press and streets. They reacted to these debates by poking fun at all involved parties: Jews and antisemites, orthodox and reform Jews, men and women, young and old, rich and poor, rural and urban citizens. By not making any exceptions, they stressed equality as the ruling principle among the ordinary citizens in society, without, however, questioning the authority of the ruling regime and its elites.

The play Nachtdienst (1902) can serve as an example of the complex web of 
relations that the Herrnfeld siblings conveyed so masterfully to their audiences. This play was the first of its kind on several counts. For the first time Berlin became the scene of action at the Herrnfeld theater. Equally important was the introduction of intimate GentileJewish relations on stage, which went beyond the realm of business relations. At a time when mixed marriages were not considered acceptable to either religious community, spectators witnessed the dilemmas of a young Jew confronted with the supposedly immoral behavior of his Gentile bride. Unlike the case in many classical theaters, spectators here were not presented allegorical plots but real-life situations. The Herrnfeld play capitalized on the familiarity of the audience with the dialects, location, and milieu presented in this drama.

The plot-line was simple: The young Gentile girl Else lives with her widowed father Gottlieb Knolle; she is engaged to a poor Jewish student named Max. Max finds out that Else is a waitress in one of Berlin's many hostess bars (Animierkneipen) in the Friedrichstraße, one of Berlin's best known amusement districts. Previously Max and Else's father had thought that she was working night shifts as a phone operator. Everybody is shocked, since the wedding is imminent, and the fathers of groom and bride are longstanding friends. To complicate matters, these two fathers had previously decided to move in together, partly out of economic necessity and partly as an expression of their mutual affection. They had hoped that their camaraderie would eventually lead to the union of their children, who had been dear friends during childhood. Prior to the scandal, the Gentile Gottlieb Knolle overcame his friend Süssel Holzer's remaining reservations about the mixing of religious backgrounds and welcomed the love-match, stressing the importance of religious tolerance and the merits of a middle-class work ethic: "Let the children do what they want, it all destiny anyway! It's all right, he'll get an honest girl, and who cares that they have a different faith, so they'll have a civil wedding; and it also has happened before, 
that he has nothing and she hasn't either and they have achieved something anyway."92 It turned out that Else, the daughter, lied to her loved ones only to eam money for her fiancé's education, so that he could pursue his studies and move out of the restricted circumstances into which they were born. In these various ways, the play appealed to its audiences not to pass judgment without first asking questions, since nothing is as clear as it seems at first sight.

The following scene is a conversation between Else's father and a family friend, Rüdersberg. Knolle is outraged and disappointed after he discovers his daughter's alleged transgressions. He vents his anger to Rüdersberg, who, in the course of the conversation, points to the hastiness of Knolle's reaction (scene 13):

Rüdersberg: [...] ...do you know at all what motives tempted her to do this? Knolle: I didn't make her do it!

Rüdersberg: I believe that, but just have a look [spinning around] at the splendid misery in this house - young blood, -- hedonism, keeping company with others who may have a bit more - good female friends - here a flounce on the skirt, silk petticoats, there another little lace - embroidered stockings; well, we can't even empathize with these things, that is exactly our social question - the spice of life, factory girl - has the desire to be someone at least once ...

Knolle: But the girl has nothing, she really has nothing!

Rüdersberg: You know, Gottlieb, at least you could have asked her why she has done it ....93

92 "Denn las doch die Jöhren machen wat se wollen, det is allens Bestimmung! Dat is ja richtig, er kriegt ja nen braves Mädchen, und von wegen, des se beede verschiedenen Glauben haben, nan, da gibts ja ne civile Ehe, und solche Fälle waren ooch schon da, dat er nichts hat und sie nichts hatte, und sind doch zu wat gekommen." Landesarchiv Berlin, Nachtdienst, Schauspiel aus dem Berliner Leben, Gebrüder Herrnfeld Theater, Rep. 30c/a, Theater Z, Neuer Teil 2320.

93 Landesarchiv Berlin, Nachtdienst, Schauspiel aus dem Berliner Leben, Gebrüder Herrnfeld Theater, Rep. 30c/a, Theater Z, Neuer Teil 2320. For the original see Appendix 2, page 291. 
In the aftermath of this conversation, Knolle confronts his daughter and asks her what drove her into the scandalous milieu of the Friedrichstraße. He and her fiancé Max are in shock when Else reveals her altruistic motifs. Her unconditional feminine love is meant to touch the men on stage and the breathless spectator alike:

Knolle: Do you wanna tell me now, what possessed you / there she stands now the Missus with the obdurate face! I would have done anything for your mother - I would have stolen - if she had been wanting anything - I would have become a burglar - to help her!

Else: I haven't done anything worse! (Pointing at Max) to help him - that money is from me! $!^{94}$

This final twist to the drama left a deep impression on the audience, and was the subject of thoughtful comments in Berlin's daily newspapers. The Berliner Lokal-Anzeiger, for example, asked who acted more immorally -- the girls who tried to make a living in Berlin's amusement centers, or their clients, who dragged the honor of their families through the mud: "Else's mistake was committed out of love for the poor student whose career she has hoped to support." ${ }^{15}$ This commentary was all the more significant because at the time the issue of prostitution occupied the German public and was considered to be a major assault on the institutions of family and marriage. By working with the grain of these issues and simultaneously giving them a particular spin, the Herrnfeld's secured the approval of their heterogeneous audiences.

This drama not only appealed to its audiences to support and accept mixed

94 Landesarchiv Berlin, Nachtdienst, Schauspiel aus dem Berliner Leben, Gebrüder Herrnfeld Theater, Rep. 30c/a, Theater Z, Neuer Teil 2320. For the original see Appendix 3, page 293.

95 "Very nice is the scene posing the question: who is more corrupt those girls or the "gentlemen" who drag the honor of their families through the mud?" Brandenburgisches Landeshauptarchiv, 30 Berlin C, Tit. 74, Th. 777, Akt. 124, Berliner Lokal-Anzeiger, November 21, 1902. 
marriages between Jews and Gentiles; it also pointed to the many achievements and merits of Jews as good and reliable citizens. The implicit argument was that the Jews' loyal service in the army provided the ultimate proof of their devotion to the nation. Hence the playwrights took pains to establish Knolle's and Holzer's common experience as Prussian soldiers in the Franco-Prussian War. Their shared front experiences at Gravelotte, the site of German victory over the French army, served as the foundation of their friendship and the basis of their equal status. ${ }^{96}$ Against this backdrop, the antisemitism that costs the Jew Süssel Holzer his job leaves both veterans speechless, disappointed and righteously angry. In the following scene, Süssel feels compelled to remind the audience of the unfairness he has suffered. Whereas the main story line supposedly focuses on the complicated love affair of their children, we can see in this passage that the fathers turn out to be the real protagonists of the play (Scene 5).

Knolle: Yes - that's true, Süssel, your Max is a decent fellow!

Süssel: If all people were like this, like you, who looks at everyone the same way, no matter whether they are Jew or Christian,-- I would not have needed anything from Tuchel, but as it is - an uproar [so e Gewalt!] ! Suddenly Tuchel goes crazy doesn't want Süssel Holzer any more! Seen - Tuchel of all people. Now, did I do anything to anyone? Did not enough people live off me? Didn't I stand with you at Gravelotte? Would I not have just as willingly sacrificed my life for the fatherland, -- didn't I, just as you, have parents at home who wept for their child? Suddenly they change [Ströhmung] - Tuchel goes crazy!

Knolle: Yes, yes, pal, you won't change that, that's always a matter of perspective, one has to stay above that! Look, for example: today the Staatsbürger runs an article, a big story, well then, good God, I'll have a good day and the paper will sell; tomorrow the Freisinnige serves up a new sensation and I'll make a bundle again, everything has its audience, and the beauty of it is that those who buy the Staatsbiurger also buy the Freisinnige - that's the kind of craziness we're

96 The victory of German troops in the battles of Gravelotte-Rezonsville (16.8.1870) and Gravelotte-Saint Privat (18.8.1870) in the Franco-Prussian War. 
dealing with! We are talking about delusions here, but because of it, old boy, the world stands, and both of us won't change it! !7 $^{97}$

At no point should it be forgotten that this dialogue was part of a farce. It poked fun at the relativity of political leanings and sensationalism in the age of mass politics, and it appealed to the audience to display tolerance and acceptance of the "other." Forbearance, moderation and pride were the principle attributes the two fathers would convey to their spectators. As members of the older generation, the two fathers had experienced the passing of time and the transitory nature of political opinions. Politics was represented in this play as "theater" in which each of the actors could perform interchangeably, according to daily events and opportunities. Knolle and Holzer thus agree that it was best not to get involved. The Jew Holzer in particular was portrayed by Donat Herrnfeld "voller warmen Empfindens, voll Strenge und Zartsinn." In short, he represented a timeless and caring version of humanity in an age of hardship, injustice and hasty judgments. ${ }^{98}$

Both fathers conversed in strong accents. While Gottlieb Knolle was what contemporaries might have called a real "Berliner Schnauze," Süssel Holzer spoke with a strong Yiddish intonation, injecting into the conversation the occasional Yiddish word, (many of which had entered Berlin Jargon long before). Instead of talking in the Yiddish language, Holzer (played by Donat Herrnfeld) inverted his sentence structures to appear "authentic." By using verbs mostly as infinitives, separated from their subjects only by a negation, the actor imitated Yiddish grammatical structures. ${ }^{99}$ In description of past events, moreover, he never used simple past but always present perfect, which requires the

97 Landesarchiv Berlin, Nachtdienst, Schauspiel aus dem Berliner Leben, Gebrüder Hermfeld Theater, Rep. 30c/a, Theater Z, Neuer Teil 2320. For the original see Appendix 4, page 292.

98 Brandenburgisches Landeshauptarchiv, 30 Berlin C, Tit. 74, Th. 777, Akt. 124, Berliner Lokal-Anzeiger, November 21, 1902.

99 See for example: "Wenn alle Menschen so wären, wie du, dem jeder Mensch gleich is ob er Jud oder Christ, - hätt ich nicht brauchen von Tuchel was ..." 
auxiliary verbs haben or sein -- a grammatical feature typical for Yiddish. At the same time, however, he did not use the Yiddish translations of these auxiliary verbs, hobn or sain. In addition, most verbs were used as reflexive verbs, preferably in connection to passive constructions. Knolle, in comparison, rambled more or less consistently in the well-known local dialect. He exchanged Koofen for Kaufen, eenen for einen, det for das, and Jott for Gott. Friends and enemies were insulted by Knolle as die Olle or der olle Kerl, belittling both in an agitated but amicable way. After all, this play was for Berliners, and Berliners had a reputation for being witty and direct. Hence the hot-headed Knolle, with his quick temper and soft heart succeeded in thoroughly captivating his audience.

This play, in short, combined universal themes with attention to Jewish issues. The "fallen" daughter's relationship to her father and questions of sexual impropriety and moral corruption were discussed in the context of mixed marriages and religious tolerance. The issue of poverty and the social question were introduced in connection with antisemitism. The Herrnfeld theater thus simultaneously appealed to its audiences on many levels. The spectator was addressed as father, daughter, or lover; as burgher, soldier or German citizen; and as Gentile or Jew. The play explored the intersection of all of these identities. No single identity was singled out as a mark of marginality. Even the daughter, at first sight victim of her own desires, humbles the others. Her love for her Jewish fiancé is as pure as her desire to marry a learned man.

While Nachtdienst was moderate in tone and humor, not least in order to establish the Hermfeld theater as a respectable house for the entire family, the drama Salomonisches Urteil (1908) was more representative of the classical Herrnfeld play, not only because of its verve but also due to its crass depiction of conflicting factions within the Jewish community. The plot centered on the search for the father of an illegitimate child. The main theme of Salomonisches Urteil thus remained true to the usual themes of contemporary bourgeois comedies (bürgerliche Lustspiele). The real attraction of the play, however, lay in the many humorous disputes between two fathers of adult 
children, who disagreed on their views of Jewish assimilation. One (Cohn) was a reputable businessman; the other (Abarbanell) was a former butcher who had become wealthy by his "invention" of white Blutwurst. These two men fought about how best to support their son, or son-in-law, whom they suspected to be in financial difficulties due to the young man's and his wife's lavish life-style. Cohn is outraged and feels estranged from his son and his in-laws, who he accuses of having ceased to respect Jewish traditions (including Jewish dietary laws). The following dialogue between Brünhilde, Abarbanell's wife, and Cohn establishes the leitmotif of this play (Scene 3, Act 1):

Brünhilde: But you must have received my invitation?

Cohn: Why must I have? I know of nothing!

Brünhilde: You are only saying that to avoid at all cost having to eat something in your son's home!

Cohn: Here we go again! I certainly won't eat something that's not kosher!

Brünhilde: How can anyone hold such old-fashioned views?

Cohn: A cleverer man than me - the great King Frederick - once remarked quite fittingly: "Let all find happiness in their own fashion."

Brünhilde: Well, does it really make a difference whether the meat is purchased from Hefter or from Rosenthal?

Cohn: Of course, it doesn't make a difference - why not buy from Rosenthal then! Brünhilde: Odd person. ${ }^{100}$

The woman's name is a symbol of her clumsy over-assimilation. The Wagnerian name Brünhilde, too pompous for a woman with little formal schooling and exposure to high culture, is meant to ridicule her desire to become "teutonic." Brünhilde, the tragic heroine of Wagner's Ring, is Siegfried's loving maid, a hero who was seen by contemporaries as the archetypical German. Since Wagner's antisemitic tendencies were well-known among contemporary Gentiles and Jews, a name such as "Brünhilde" might well have signaled self-hatred. Cohn, by contrast, represented the ideal typical name for a Jew. Often

${ }^{100}$ Landesarchiv Berlin, Salomonisches Urteil, Gebrüder Herrnfeld Theater, Rep. 30 c/a 
experienced as a stigma by many German Jews, the name "Cohn" is carried with pride in this play. Indeed, the character Cohn bemoans his son's attempt to shed his Jewish identity by buying a noble name. Quoting Frederick the Great, who was known for his religious tolerance, Cohn insists on his right to be different by obeying the dietary laws of the Jewish tradition, a position Brünhilde could not grasp. Fredericks famous words "Lass Jeden selig werden nach seiner Facon" becomes the motto of this play, a motto that encapsulates the defensive position of the Enlightenment in times of romantic passions and delusions.

The Herrnfelds spoke out against unconditional assimilation, which would inevitably lead to the disappearance of a shared heritage. By making Cohn the most sympathetic character of the play, they gave their audiences a clear message. They appealed for the acceptance of private difference, secured by the rights of the individual, in a society governed by a shared humanitarian consensus. They ridiculed those Jews who desired to hide their ethnic identity behind antiquated titles and noble names by portraying most nobles as thoroughly snobbish and corrupt, living off their pasts glory and stifled by mindless rituals, such as five o' clock teas. The following dialogue between the two fathers underscores the two antagonistic positions. (scene 10):

Cohn: I always knew it was going to end like this,-- the thousand mark bills were just flying around! Why was it necessary for him to get a different name?

Abarbanell: You don't understand that!

Cohn: Well that is quite the nasty trick by a healthy man, where the father will still live to be a hundred years old - to get himself adopted by a baron! - This adoption cost a fortune, you know!

Abarbanell: It wasn't that bad!

Cohn: He has to be called Klamm-Cohn! Cohn by itself wasn't good enough for you!

Abarbanell: Cohn by itself is no longer a real name these days!

Theater Z. Neuer Teil 4030. For the original see Appendix 5, page 293. 
Cohn: angry/ There are millions of Cohns!

Abarbanell: That's not enough!

Cohn: Well, there you are!

Abarbanell: You are forgetting that your son has already attained an established position in society!

Cohn: This established position has broken his neck! He had to arrange Fife de Glockes - Fife de Glockes! I can't even pronounce it!

Abarbanell: Well, you are agitated now!

Cohn: And balloons rose up! Confetti thrown down on the people! Everywhere the mother-in-law was present - the old butcher's wife! $!^{101}$

In the course of their conversations, Cohn incessantly appealed to his son "to stay true to himself" and not to deny his past. ${ }^{102}$ The play concluded by identifying the father of the illegitimate child in a court case.

Often, the Hermfeids included court scenes in their dramas, for they allowed the characters to explain themselves and their motives directly to the spectator. Cultural differences, most apparent in the colorful accents of the individual performers, clashed in a way that was hard to present in a scene drawn from daily life, where these differing parties might not share the same milieu. A court scene was able to bring the most unlikely combinations of individuals together, often in the dramatic resolution of a long and complicated plot.

\section{Aesthetics and the First World War}

The outbreak of the First Wold War fundamentally altered the censorship policy of

101 Landesarchiv Berlin, Salomonisches Urteil, Gebrüder Herrnfeld Theater, Rep. 30 c/a Theater Z. Neuer Teil 4030. For the original see Appendix 6, page 294-95.

102 Landesarchiv Berlin, Salomonisches Urteil, Gebrüder Herrnfeld Theater, Rep. 30 c/a Theater Z. Neuer Teil 4030. 
the Prussian authorities. Anton and Donat Herrnfeld quickly reacted to new censorship rules that required the theater police to ban musical comedies, operettas, farces and variety shows. While in the pre-war period these genres had passed the censors without difficulties, they were now considered to be too frivolous or trashy. ${ }^{103}$ Upon the outbreak of the war in August 1914 the Herrnfelds were presenting the play Mandelbaums Hochzeitsreise, a burlesque comedy about the Jew Mandelbaum who married out of financial greed and who desperately tried to escape his marriage after the "deal" did not turn out as favorable as he had hoped. ${ }^{104}$ The Herrnfelds sought to prevent the possible closure of their establishment by volunteering to change the style of their performances completely. On 24 August 1914, they filed the following request to Berlin's theater police. Compared to earlier requests this letter is strikingly different in tone. A cheerful assertive tone gave way to a diplomatic and moderately submissive one:

Since in the present serious times we do not deem it appropriate to put on stage our merry comedy Mandelbaum's Hochzeitsreise ('Mandelbaum's Honeymoon'), we have adapted a patriotic play, Er kommt wieder ('He comes again'), a war episode by Anton and Donat Herrnfeld. Enclosed we are submitting a copy in duplicate for your obliging censorship and approval, with the request kindly to grant the latter immediately." 105

Er kommt wieder was the first Herrnfeld play after the declaration of war in August 1914. The new play captured the anxious desire of the Jewish community to belong to the "true" Germany as well as Anton and Donat Herrnfeld's concern to harmonize their entertainment

${ }^{103}$ Stark, "All Quiet on the Home Front," 62-63.

104 "The farce Mandelbaums Hochzeitsreise allows the author-actors Anton and Donat Herrnfeld to really develop their abilities as actors. The desperate struggle of Mr. Mandelbaum to escape a marriage into which he has entered out of financial greed, without, however, to endanger the success of his "deal," provokes scenes of earth-shattering comic effects. Storms of laughter and loud demonstrations of approval rewarded the excellent performance." Brandenburgisches Landeshauptarchiv, 30 Berlin C, Tit. 74, Th. 779, Akt. 219, Berliner Börsen-Courier, August 2, 1914.

${ }^{105}$ Brandenburgisches Landeshauptarchiv, 30 Berlin C, Tit. 74, Th 779, Akt. 227. 
genre with the new censorship requirements, which demanded sincerity and national devotion -- two very humorless mandates. It also captures the spirit of the first weeks of the fall of 1914, when enthusiasm for the war and righteous indignation were widespread among German citizens. Er kommt wieder was greeted by the censorship with an unusual degree of enthusiasm, since it refrained from the facetiousness that had attracted the Hermfeld audiences in previous decades. The Herrnfelds followed the new directives and were thus approved by the theater police. ${ }^{106}$ Nevertheless, Berlin's theater police subjected each new play to increasingly close scrutiny:

There are no principled reservations against public performance of the one-act play $E r$ kommt wieder. It deals with the familiar events resulting in the Great War of 1914 , stresses particularly the settlement that was suddenly reached between Czechs and Austrians on one hand and the various confessions in Austria on the other hand, and at the centre of which is the emergency wedding [Nottrauung] of the conscripted Moses with the Christian Rosl, daughter of the mayor. ${ }^{107}$

In Er kommt wieder, a mixed marriage between a Jewish man and Christian woman was again central to the plot. In a departure from previous Hermfeld plays, the children did not consult their parents before they exchanged vows. Whereas the horse dealer Moses was understanding and supportive of the young couple's choice, Joseph Grieshuber -- a bailiff and the father of the bride -- felt betrayed and disappointed. Moses, the father of the groom Jacob, appealed to Joseph to sanction the hurried wedding: "Gemeindevorsteher überleg was Du sagst. Wenn zwei junge Menschen sich lieben und finden, daß sie zueinander passen -- dann sollen sie sich auch heiraten, das ist mein Standpunkt -- also schlag schon

106 The war brought a change in the proceedings of any forms of censorship. "Although civilian administrators and communal officers continued performing their normal functions, they were now obligated to follow orders and special ordinances of the commanders, who in turn were answerable only to the Emperor." Stark, "All Quiet on the Home Front", 60. 107 Brandenburgisches Landeshauptarchiv, 30 Berlin C, Tit. 74, Akt. 227. 
ein und Du machst zwei Menschen in dieser schweren Zeit glücklich." ${ }^{108}$ Unlike in previous dramas, the Gentile father reacted violently; he rejected not only his son-in-law but also his daughter: "It remains as I say [...] My child is dead for me -. . . ${ }^{109}$ Much time is spent of the first half of the play in heated dialogue between the two fathers. Moses repeatedly beseeches Joseph to give his blessing to his daughter's choice:

Moses: Joseph, I beg you once more, not for me, but for my son. - Look - my only son takes to the field today - and, and - with him thousands of our sons of all confessions, and they march side by side, shoulder to shoulder, without asking what is your religion? They are going to war together in order to free their coreligionists from the Russian yoke, and the Jew will not ask: is that not a Catholic whom you have liberated? The Catholic won't ask: is that a Muslim you have freed? - No - they know not the difference in religion, because it's called justice to stand up for humanness. And you who stay home, you want to think otherwise? That is mean of you.

Grieshuber: /excitedly/ You will never change my mind, despite all your smooth talking. If my daughter has acted against her father's will, then let her go on her own path alone -

Moses: Why has she acted against her father's will? Because she wants to let the warrior take to the field with an easier heart. She has sacrificed herself for the fatherland: For the most sacred duty in war is - first your fatherland, then your family - and in the last place your faith - . ${ }^{10}$

In this scene Moses --the voice of the reason --tries to illuminate the clouded judgment of his friend and fellow citizen Joseph. Moses uses universal and humanitarian concepts such as "human love," "justice" and the tolerance of other religious beliefs in an uneasy junction

${ }^{108}$ Landesarchiv Berlin, Er kommt wieder, Gebrüder Herrnfeld Theater, Rep. 30 c/a Theater Z. Neuer Teil $6015 \mathrm{a}$.

${ }^{109}$ Landesarchiv Berlin, Er kommt wieder, Gebrüder Herrnfeld Theater, Rep. 30 c/a Theater Z. Neuer Teil 6015a.

110 Landesarchiv Berlin, Er kommt wieder, Gebrüder Hermfeld Theater, Rep. 30 c/a Theater Z. Neuer Teil 6015a. For the original see Appendix 7, page 295-96. 
with very specific concepts such as "fatherland," "duty," "battle" and "war." The defensive undertone of Moses' plea, and the contradictory values in his system of morals, reveals the helplessness of liberal and humanitarian thinkers, who were confronted with a war they did not want, but which they had not helped to prevent either. The Herrnfelds wanted to preserve their own voice without losing their foothold in the entertainment market. They felt compelled to follow the directives of the new order, which only tolerated whatever furthered the war effort, and thus appealed to their audience with what they thought to be a suggestive combination of outdated rationalism and contemporary emotionality. In August of 1914 their strategy seemed to work out, at least as long as the Burgfrieden lasted.

After Jacob the groom proved himself to be a virtuous man of high morals, Joseph came around to accept him as his son-in-law, although not without making the inevitable reference to the Holy Scripture. Joseph Grieshuber accepted his son-in-law as the new guardian of his daughter." "The new spirit of the time demanded clear-cut gender roles; men were warriors and providers, who guarded and protected subordinate women; such an order was ordained and sanctified by the Almighty himself. In earlier years of Jargon entertainment, as in so many of the Shakespeare's dramas, men most often appeared as the intellectual inferiors of their wives. Driven by their desires into extramarital affairs, they were inevitably caught by their suspicious and strong-willed wives, who anticipated most of their moves. The audiences wanted and expected to see the pattern of unfaithful husbands and their domineering wives because it partly reflected, and partly inverted, ruling gender stereotypes. Such a dramatic scheme allowed for many comical effects. In 1912, only two years prior to the play Er kommt wieder the Vossische Zeitung had identified this pattern with mixed feelings as a leitmotif at the Hermfeld theater:

Not that the playwrights digressed from their usual theme of husbands whooping it up

111 "The woman shall leave father and mother behind and follow the man - love each other and pray to God that he will return safely." Landesarchiv Berlin, Er kommt wieder, Gebrüder Herrnfeld Theater, Rep. 30 c/a Theater Z. Neuer Teil $6015 a$. 
and their wives unerringly catching them, but they know how to present the well-worn subject in constantly new ways, often using surprising puns and indisputably hilarious situations to give the audience's laughing muscles a workout. ${ }^{112}$

After August 1914, however, the Hermfeld theater gave up the highly successful depictions of marital conflict in order to secure the continuing existence of the enterprise. $E r$ kommt wieder thus represented a decisive break from the stylistic elements that had been so typical for the Herrnfeld Theater. Berlin's local press commented on this sudden conversion. The demonstration of national sentiments was welcomed as a true patriotic gesture, appropriate to evoke a new sense of community:

This too is a piece of Berlin: that the Herrnfeld brothers belong to the first ones who have the courage to open their theater again. They cannot cling to 'purity of style' but have to take into account the general mood. In particular, they do this with the patrioticsentimental one-act play 'Er kommt wieder', in which the playwrights, Anton and Donat Herrnfeld, effectively dramatize an incident at the German-Austrian border that occurred on the day of the declaration of war. The closing scene, when the 'Wacht am Rhein' ('The Guard on the Rhine') is played on stage, turned into powerful patriotic demonstration, as the entire audience joined in." 13

Moreover, the Herrnfelds traditionally chose humorous and grotesque names for their main characters, the names in Er kommt wieder were solemn and serious in comparison. In previous years, the Herrnfelds had named their Jewish stage characters Blumentopf, Rosenblatt, Goldstücker, Morgenstern, or Perlmutter, and unlike other theaters they also found equally profane names for their Gentile characters such as Wisskotschil, Knolle, Grieshuber, von Klamm, Neuendorf, Hansa, Böhmer or Nepomuk. ${ }^{114}$ In the classical

112 Brandenburgisches Landeshauptarchiv 30 Berlin C, Tit. 74, Th. 779, Akt. 140, Vossische Zeitung, October 6, 1912.

113 Brandenburgisches Landeshauptarchiv, 30 Berlin C, Tit. 74, Th. 779, Akt. 229, Deutsche Monatszeitung, August 31, 1914

${ }^{114}$ The origins of Jewish surnames in their great majority fell into four categories: "1. names of origin (e.g. 'Berliner'), 2. Patronymics ('Davidsohn'), 3. occupational names, 
theater canon, the "Jewish" name was meant to single out one individual in a potentially hostile environment. Thus Jews were meant to personify the alien souls living on the fringes of society. In Jargon theater, however, preposterous names had been used on stage to unify a community of individuals of divergent social standing and background. These theaters had thus suggested a normality in Gentile-Jewish relations, which for at least some members of the audiences corresponded to lived reality. The name of each Jargon theater character, although colorful and often ridiculous, was not meant to function as a stigma, it had lost its singularity. Prior to the war the traditional division of character roles among the two Herrnfeld directors had also permitted allowed for a more balanced view of Germany's ethnic groups. Anton and Donat Herrnfeld operated as a comedy-team with a very similar relationship in each of their plays: Donat Hermfeld impersonated a Jew, whereas Anton Herrnfeld played a Gentile. This division allowed them to poke equal fun at both sections of society, without offending either of them or focusing exclusively on Jewish types. Anton Hermfeld specialized in the character roles with Slavic names and origins -- shrewd and canny, with an eye to their personal advantage -- while Donat Hermfeld, the leading Jewish character, was soft, agitated and warm-hearted. Their types were well summarized in the following description by W. Fred, published in Die Schaubühne in 1912:

Donat Herrnfeld shows the specifically Jewish manner of passing from controlled agitation into a fit of rage; Anton Hermfeld portrays a naïve cleverness behind a mask of idiocy. The instruments of both actors are more gestures -- something rhythmical, so to speak -- than words per se. Both make you laugh because one gets less the feeling of 'theatre' than the recollection of having met people like that. And the amazement about the fact that there are such people among us, combined with the conviction that despite all external changes the essence of these archetypes are, if not eternal, at least persistent 'for up to a hundred years', results in a powerful comical effect. Therefore, one feels closer

attributive names, nicknames ('Perlmann'), arbitrary names ('Goldberg')." It is interesting to note that names employed by the Hernfeld brother prior to 1914 always fell into the last two categories. Dietz Berding The Stigma of Names. Antisemitism in German Daily Life, 1812-1933 (Ann Arbor, MI., 1992), 17. 
to the Jew than to the Bohemian. One would like to see a master play with the Herrnfelds, Vienna' and Pest's Eisenback and Rott who are really great character actors, with Schildkraut and a Jewish Nestroy who writes a play for them: without superiority vis-à-vis the milieu and the jargon, robust and moving like the Jewish songs that unfortunately cannot be heard in these parts. ${ }^{15}$

After August 1914, the lightness, ease, and "normality" of Gentile-Jewish relations among actors and in the audience suddenly became more complex. No careless or ambiguous jokes were cracked; sensibilities were no longer challenged, but instead carefully respected. In place of Isidor Blumentopf, the protagonist was now named after Abraham, Moses, Jacob or some other biblical figure. By contrast, when the protagonist's their Gentile counterpart became Joseph Grieshuber instead of Gottlieb Knolle, a much less conspicuous "improvement." Biblical names put the Jewish stage characters beyond reproach and ridicule, transferring them into heroes whose declarations were prophecies directed at the audiences. These biblical names ironically enhanced the separateness of these Jews to their Gentile counterparts. Now they were once again Jews in the Diaspora, a community bound together by the threat of "the other." There were no intra-family conflicts between fathers and sons, the conflict line now separated the Jew from the Gentile. Full of conventional wisdom and very little humor, these new plays could only compensate these deficiencies by incorporating into scripts what appears today to be bounded sentimentality.

Er kommt wieder was sufficiently successful among audiences and censors that the Herrnfelds soon produced the sequel So leben wir! ("This is how we live!"). ${ }^{116}$ The same little village at the border with Germany's ally Austria-Hungary provided the setting of the play. ${ }^{117}$ Taking up where Er kommt wieder had ended, this sequel described the

115 W. Fred in Die Schaubühne 2 (1912), 420.

116 Brandenburgisches Landeshauptarchiv, 30 Berlin C, Tit. 74, Th. 779, Akt. 232.

117 "The new play that Anton and Donat Hermfeld wrote for their stage deals again with issues that deeply move all of us. It is set in a normally quiet little village at the German-Bohemian border that is deeply affected by the waves of enthusiasm in the wake of the war and in 
experiences of the first year of war on the home front, which were conveyed to the audience largely through press releases and occasional messages from soldiers. Jacob's letter from the trenches is a key example of Jargon theater's new tone during the war. On the surface, it described how trench experiences à la Ernst Jünger, shattered the comfort, security and harmony of bourgeois homes. Jacob's letter arrived at a moment when everyone thought him already dead. His family therefore read his lines as the last farewell of a heroic warrior:

[T]ndeed all seems lost for us - I can see how everyone is withdrawing -; the only chance is to act quickly: "People, we must not abandon our comrades, if it must be like that, we'll all die! With these words I storm to the front, my rifle high in the air. - We hold out for a long time in the murderous fire - but no help arrives. - How shall this end?! .... [D]on't be afraid, give my best to my Rosel, and let me embrace all of you affectionately, - and should I die - I'm dying for you - for my wife - and my fatherland - Yours, Jacob! ${ }^{118}$

The Herrnfelds tried to bond with their audiences over the communal experience of a letter from a loved one. Since many families had sons at the front, spectators could identify with the anxieties and uncertainties presented on stage. The Hermfelds did not, however, subscribe to the notion that war was a chivalrous game fought by gentlemen distinguished by their posture and composition. Their war was dirty and frenetic, and had to be survived day to day. By presenting this kind of war, the Hermfelds offered a tribute: to naturalistic drama, and to their Jewish roots. Although they singled out Jacob out as someone whose courage in the end rescued others, it was what he did alone, but how he could motivate others to work together, that constituted his heroism. He was not a solitary fighter on a

which national and religious antagonisms are set aside for the national cause!" Brandenburgisches Landeshauptarchiv 30 Berlin C, Tit. 74, Th. 779, Akt. 236, Berliner Neueste Nachrichten, November 1, 1914.

118 Landesarchiv Berlin, Er kommt wieder, Gebrüder Herrnfeld Theater, Rep. 30 c/a Theater Z. Neuer Teil $6015 a$. 
mission, but a responsible comrade who did not want to abandon his fellows (and who was then rescued by them). In the end, Jacob did not die, but the spectator was left wondering whether his survival was due to destiny or simply chance.

One of the most striking aesthetic departures evident in these plays was the absence of ethnic or local dialects. Neither Jews nor Gentiles spoke with heavy accents. Thus Jargon theaters ceased in effect to present Jargon of any kind. Whereas every intonation was indicated in the scripts of earlier plays, there was no sign that the actors were asked to perform in specific dialects or accents in Er kommt wieder or So leben wir! Such linguistic differences would automatically have set the individual actors apart and would have destroyed the fragile sense of a national community. This was precisely the effect that Jargon theater directors now wanted to avoid. The virtuoso display of "authentic" accents and dialects was apparently a feature of public performance that neither the Hermfelds nor their audiences thought appropriate or welcome in times of national crisis.

The patriotic sequel was not a great hit for the Hermfeld theater. The longer the war lasted, the more German audiences' initial enthusiasm for patriotic plays dissipated. Spectators wanted to be entertained and amused, but not tutored. Sensing this, the Herrnfeld brothers consequently tried to introduce situational humor in So leben wir! whenever it was politically opportune. In November 1914 , the press, and in particular the Berliner Morgenpost, was positively impressed with their delicate balancing-act, carefully weighing humor and patriotism:

At the Herrnfelds' one does not only laugh, a considerable stream of tears also flows from beautiful eyes every evening. The two playwright-directors Anton and Donat Hermfeld have adopted a new tone for their new work -- So leben wir (Thus we live), premiering last Saturday before a full house -- that is unusual for this temple. And one must acknowledge that the playwrights have molded with a sure eye for what's effective on stage, for a work that rises significantly above other more or less skillfully jumbled casual plays. Without any obtrusive jingoism, without kitschy sensationalism, they have shaped material that reveals that they have followed the events of these great times with open eyes and ears. Their characters are drawn in minutest, life-like detail; they grip all 
the more, because without exception they are splendidly portrayed.. .It's superfluous to mention that humor comes into play quite abundantly. ${ }^{119}$

\section{The Folies Caprice}

The Folies Caprice was an uncouth version of the Gebrüder Herrnfeld Theater. Whereas the Folies Caprice imitated and parodied classical theater in the same manner as the Herrnfelds, it also exploited the successes of other popular theaters, such as the Metropol Theater. In the first decade of the new century, revue theater had become immensely popular among masses and elites, and had begun to replace more traditional variety and cabaret theaters. Revues habitually made reference to current scandals and events and caricatured famous personalities in politics and high society. Whereas the Metropol Theater was known for its lavish, disciplined and fine-tuned revues, the Folies Caprice often presented a cruder, more openly sexual version of the same genre. Provocative Jargonjokes (Anrïchige Jargon-Witze) were the centerpiece of every performance, and they often risked censorship on account of their indecency. Lastly, whereas the Herrnfeld theater had a reasonably strong plot line in each of its plays, the Folies Caprice typically presented a series of loosely connected sketches. ${ }^{120}$

${ }^{119}$ Brandenburgisches Landeshauptarchiv, 30 Berlin C, Tit. 74, Th. 779, Akt. 235. 120 "Yesterday night, the Folies Caprice presented the premier of the revue "Mal was anders." Just like the Metropol theater, this farce, full of crude jokes and contemporary allusions, deals with today's personalities and events. The funny play, full of effective Verwandlungsrollen, was greatly appreciated; many couplets, songs and dance scenes had to be repeated. This glorious sensation was prefaced by a humorous one-act play by Blitz and a comedy by Drosky, who portrays so well the situation in Pest [die Pester Zustände]. The gentlemen Mertens, Fleischmann, Grünecker, and Schreiner did not fail to present their anrüchigen Jargonwitze." Brandenburgisches Landeshauptarchiv, 30 Berlin C, Tit 74, Th. 
In the early years of its existence, the Folies Caprice appeared to offer an even more "authentic" depiction of a specific Jewish milieu than did the Herrnfeld theater. ${ }^{121}$ By 1911 , it seemed to have lost most artistic ambitions, however. III. Klasse, for example, a play by Max Ernst and a spin-off of a famous satire by Ludwig Thoma, did not captivate its audience with its differentiated portrait of Jewish life in Germany. Without being particularly original it nevertheless opens a window on the Witzkultur of the time. ${ }^{122}$ Like many farces at the Folies Caprice, the entire action of III. Klasse was confined to one location - a train car on its way through Posnan. As passengers boarded and left the train, their conversations provided the plot for the play. The following scene is representative of such encounters. The main Gentile character Wallowitzer was a witty, sharp-tongued married man who was always ready for a little romantic encounter. Having managed to engage a young, attractive woman in a flirtatious conversation, his plans are upset by the arrival of a Jewish couple in his compartment. Their presence threatened to disturb his little tête-à-tête. Wallowitzer tried to discourage the couple from staying by insulting them:

845, Akt. 241, Vossische Zeitung, December 21, 1907.

121 In 1906, the critic Walter Turszinsky praised the oeuvres of the Folies Caprice as "echt, wie Sabbathfische in Buttersauce." Walter Turszinsky, "Jüdischen Theater" in Die Schaubühne 1 (1906), 446.

122 "Yesterday (Friday) two comedies by Max Ernst premiered at the Theater Folies Caprice; both had everyone laughing. [...] The other one, 'Dritter Klasse' ('In third class'), is a railway skit entirely in the tradition of the well-known farce à la Thoma, except that it was transplanted from the first into the third railway class and from the Bavarian highlands into the fields of the province of Posen. Although the idea was not new, the execution of the satire was nevertheless exceptionally funny. The best actors, above all Messrs Berisch and Müller, once again took the opportunity to showcase their performing abilities and dialectic talents. As the entire show was also rich in jokes and baffling, hilarious situations, the audience couldn't stop laughing and at the end applauded enthusiastically. Mr. Ignaz Wallowitzer's railway compartment adventures will likely dominate the program of the Theater Folies Caprice for some time." Brandenburgisches Landeshauptarchiv, 30 Berlin C, Tit. 74, Th. 847, Akt. 19, Berliner Lokal-Anzeiger April 22, 1911. 
Wallowitzer: Since we're sitting together so comfortably, allow me: Wallowitzer is my name.

Eichkutz: There you go! Isedor Eickutz, and my wife Sara.

Wallowitzer: (makes a bow) Ah, Sara, the ancient biblical mother.

Eichkatz: Well, my wife isn't that old.

Wallowitzer: Ah, what's a few days.

Sara: (to Eichkutz) Isedor, you let me be insulted like this.

Eichkutz: (flying at Wallowitzer threateningly) You! (Suddenly, with a look to

Sara, in a calm voice.) Ah, what the heck, I guess you are right. ${ }^{123}$

In the course of the scene the Jew Eichkutz and his perspectives on life became an endless source of conversation for Wallowitzer. A stream of loosely connected dialogues such as the following, crowned by a more-or-less well-placed punch-line at the end, was the typical format of most plays at the Folies Caprice:

Wallowitzer: (to Eichkutz) What's the matter, Mr. Eichkutz, why are you wearing a black tie? Are you grieving?

Eichkutz: Sure, after all, Rothschild has died.

Wallowitzer: Well, were you related to him?

Eichkutz: No that's exactly why I am grieving. ${ }^{124}$

Jokes about the Rothschilds and their extraordinary wealth were very common, especially among Germany's antisemites. Unlike most jokes of this kind, however, the author here chose to present the Jewish perspective: it is Eichkutz who completes the punch-line and not Wallowitzer. Nor is Rothschild an object of ridicule or portrayed as the master of a Jewish world conspiracy -- a theme very common in German antisemitic discourse. The

${ }^{123}$ Landesarchiv Berlin, III. Klasse, Max Ernst, Folies Caprice, Rep. 30 c/a Theater Z. Neuer Teil 5049. For the original see Appendix 8, page 296.

${ }^{124}$ Landesarchiv Berlin, III. Klasse, Max Ernst, Folies Caprice, Rep. 30 c/a Theater Z. Neuer Teil 5049. 
fool is not the greedy Jewish banker, but rather the petty-bourgeois Eichkutz, who envies his wealth. ${ }^{125}$ This joke took the edge off these issues, by focusing on the envious common man instead of the banker. It addressed one of the most critical arenas of GentileJewish encounters: politics and money. The joke suggested to the listeners that one might share interests, even when one did not share identities.

The Jewish parvenu and his problematic encounters with Germany's aristocratic society played a central role in the Folies Caprice. ${ }^{126}$ Unlike the Herrnfeld theater, which mostly focused on the bourgeois family, the Folies Caprice subjected to ridicule and laughter the parvenu's quest for respectability, distinctions, honors and titles. In retrospect it is often unclear whether the audiences laughed at or with the actors, since well-known stereotypes were often reproduced at the Folies Caprice. Its actors, however, softened the effect by treating both Gentiles and Jews to equal heavy doses of their acid humor. Their jokes were as much a reflection of a specifically Jewish type of humor as they were a reflection of how jokes at the time were made in general. The Imperial public was by no means as irritated by ethnic stereotypes as it is today. In German comedy, as in German folklore, sly Bohemians coexisted with stiff Prussians, and dumb Bavarians. Jewish stereotypes were no exception here.

As did other theaters, the Folies Caprice altered the content of its plays dramatically

125 This particular joke was very well known at the time and reemerged in various collections of Jewish humor. More than ten years later, in 1922, for example, Alexander Moszkowski (1851-1934), one of the most famous humorists and journalists of his time, included a slightly altered variation in Der jüdische Witz und seine Philosophie: "When the old Bleichröder had passed away, a stranger was noticed among the mourning, shedding bitter tears. He was asked: "But are you a relative of the deceased? " Unfortunately I am not at all related to Bleichröder; that's why I am crying!" Moszkowski merely exchanged Bleichröder for Rothschild. Alexander Moszkowski, Der jüdische Witz und seine Philosophie. 399 Juwelen echt gefaßt von Alexander Moszkowski (Berlin, 1922), 74. Gerson Bleichröder died in 1893. Baron James de Rothschild died in 1868.

${ }^{126}$ Brandenburgisches Landeshauptarchiv, 30 Berlin C, Tit. 74, Th. 847, Akt. 176, 1912. 
after the outbreak of the war. One drama -- Fest steht und treu... oder sei stolz, daß Du ein Deutscher bist -- offered everything its title promised. It was one of three new plays staged in 1914 that explicitly dealt with the war. According to the Berliner Lokal-Anzeiger, the tone of the play struck a responsive cord among the population, which was fascinated by the challenges introduced by the war. Even more so than did the Herrnfeld theater, the Folies Caprice tried to blend its typical slapstick humor into its new patriotic sketches. ${ }^{127}$ Whereas the Hermfeld theater tried to preserve and integrate its philosophy on Jewish assimilation into its patriotic plays, the Folies Caprice did not tend to reflect on what the war would mean for Germany's Jews. Like the Hermfeld theater, the Folies Caprice used conversations between members of different generations to explain contemporary events and out-looks. In Fest steht und treu, landowner Böhnke, while observing the marching troups, explained to his enthusiastic daughter Anna what the war was all about: ${ }^{28}$ Although there was no identifiable Jewish character in this play, community and the nation were key concepts at work. Exclamations such as: "a folk that it united, that is glowing, living, working for its fatherland, such a folk will not be defeated." or "We are German brothers, and our Kaiser has said he does no longer recognize any parties " were woven into the play at every suitable occasion. ${ }^{129}$ At the outset of the play it is not clear who is actually meant to be part of the German nation. As the story unfolds, however, it turns out that being German is a matter of self-perception, not of birth.

To make this message easily accessible to a wider audience, the Folies Carpice chose a "classic" scenario. Two young men, named Hermann and Charlé, are competing

127 Brandenburgisches Landeshauptarchiv, 30 Berlin C, Tit. 74, Th. 848, Akt. 54 RS, September 22, 1914; Brandenburgisches Landeshauptarchiv, 30 Berlin C, Tit 74, Th. 848, Akt 58, Berliner Lokal-Anzeiger, December 28, 1914.

128 Landesarchiv Berlin, Fest steht und treu.... oder sei stolz, daß Du ein Deutscher bist, L. Haskel, Folies Caprices, Rep. 30 c/a Theater Z. Neuer Teil 6043.

129 Landesarchiv Berlin, Fest steht und treu.... oder sei stolz, daß Du ein Deutscher bist, L. Haskel, Folies Caprices, Rep. 30 c/a Theater Z. Neuer Teil 6043. 
for Anna's love. Hermann, a farm laborer who was among the first recruits to volunteer for service at the front, is at first outdone by the slick Charlé, whose charms have blinded both father and daughter. The purifying effect of the military mobilization, however, brings the real nature of both rivals to light. Charlé, the son of French citizens who has lived as a German citizen in Germany his entire life, turns out to be a deceitful French nationalist. He has capitalized on the German fascination with French manners, fashion and refinement. Hermann, by contrast, is a ponderous, uneducated farmer with upright morals, enflamed by his loyalty for Germany and his true love for Anna. In the end, the situation is resolved when Anna decides that she prefers the simple man with the "right" education of senses over the one who combines deceit with polished refinement. Her initial infatuation with Charlé fades in favor of Hermann, paralleling Germany's actual mobilization.

Carrying the same name (Hermann-Charlé), Hermann was presented as Charlé's alter ego, as German culture's answer to French civilization. In a shouting match Hermann accuses Charlé of being a traitor:

"Charlé /scandalized"/ What? Me a traitor of the fatherland?

Hermann: Precisely, that's what you are, when you as a German are taking pleasure in fake news. Do you really believe I haven't heard what you whispered joyfully to old Marianne: this time the Germans will likely have a bit of a tougher stand than in 1870. But one often miscalculates, even the Grande Nation. However, we are at least considerate to the French gentlemen, and because we know they also like chocolates, we have presented them with a few $42 \mathrm{~cm}$ chocolate truffles. Those things are hard to digest and you can easily upset your stomach on them. The Frenchmen who always march at the forefront of civilization. Yes, old Zeppelin with his airships, that's an invention, isn't it? And we are merrily applauding at the sight of such a mighty liverwurst and shout: All that's good comes from above. And no matter whether we'll have more trouble this time than in 1870, I probably won't be able to discuss it with you, Mr. Charlé, after the Great War. My doctor has advised me that in order to stay healthy I have to forget anything disagreeable, and you know, where I'll begin to forget first - 
with you, Mr. Charlé."130

In the end, it is socialization and not birth that makes Hermann feel German and Charlé feel French. Hermann's family history is a complicated one, but boils down to the fact that he had been born as a French citizen to French parents and lost contact to his real family through fateful circumstance. He was adopted and raised by a Prussian officer. Faced with the calamity of war, he opts for Germany as his fatherland, even though he knows about his French origins. Hermann feels German, and thus thinks himself to be German, a case that was not foreseen in Germany's citizenship law. In the context of citizenship and national identity the Folies Caprice thus went against the grain of the contemporary legal framework, despite its need to take a rather conformist stand on most political issues. It deliberately did not subscribe to racial thinking at a time when the latter was increasingly common among the German public at large.

With the Zeppelin the Folies Caprice employed a symbol that originally had carried two conflicting hopes: the transcendence of human boundaries, and the desire for military and cultural superiority. In 1909/10, aviation still bestowed hope in some Germans that it would "bind nations together, and unify diverse people." 31 Just as the humanitarian and international notions of "justice" and "human love" were used in the Gebrüder Hermfeld Theater as a means to bestow legitimization on Germany's wartime struggle against foreign enemies in 1914, a symbol of internationalism had been transformed in the Folies Caprice into a vehicle to arouse chauvinistic sentiments.

In the monologue cited previously, Hermann revealed himself to be a middle-class nationalist, identical in outlook and sentiments to the audiences of the Folies Caprice. The

130 Landesarchiv Berlin, Fest steht und treu.... oder sei stolz, daß Du ein Deutscher bist, L. Haskel, Folies Caprices, Rep. 30 c/a Theater Z. Neuer Teil 6043. For the original see Appendix 9, page 296-97.

13 I John H. Morrow, Jr., "Knights of the Sky. The Rise of Military Aviation," in Coetzee and Shevin-Coetzee, eds., Authority, 307. 
reference to the Zeppelin was not accidental, since - despite the vain hope of pacifists -- it was widely conceived as a powerful symbol of the superiority of Germany's cultural and technological superiority. ${ }^{132}$ Although Hermann is neither eloquent nor insightful, the audience is asked to accept his implicit identification of his own status with the Zeppelin, the "mighty liver sausage," that Germans considered slow but effective in warfare. ${ }^{133}$ Even the food metaphor attacked French cuisine, which was still considered by many gourmands to be superior to the rather pedestrian German fare. Hence even without being born to German parents in Germany, Hermann turns out to be a true German patriot at heart. As such, he is a character with which Gentile and Jewish audiences could identify their entire being -- head, heart, and stomach.

132 Morrow, Jr., "Knights of the Sky," 306. See also Peter Fritzsche, A Nation of Fliers: German Aviation and the Popular Imagination (Cambridge, MA., 1992), 6-43.

133 "French accounts often depicted German aviators as fat, florid types in large slow planes, while claiming that the energy and initiative necessary to use airplanes accorded marvelous with Gaelic audacity." Morrow, Jr., "Knights of the Sky," 310. 


\section{Conclusion}

Artistically rooted in many different entertainment genres, including variety theater, Yiddish theater and classical theater, Jargon theaters were by definition a hybrid form of entertainment. They were arenas that blurred the boundary between the private and public spheres, allowing Gentile and Jewish spectators to enjoy exceptional intimacy despite belonging to a society defined by rigid distinctions of class, gender and ethnicity. Whereas scholars such as David Sorkin, Marion Kaplan, Shulamit Volkov and Gershom Scholem agree that a "private Jewish culture" continued to exist in Imperial Germany, they emphasize how Jews generally aspired to follow the formula of the Haskala: "be a human being out of doors and a Jew at home. ${ }^{\text {"134 }}$ However, popular entertainment permitted Jews to transcend this essential distinction. By focusing on the family, the most intimate sphere in which Jews experienced and defined themselves as Jews, Jargon theaters turned the private into a public affair. On stage, where they were watched by hundreds of Jews and Gentiles every night, Jews appeared to reaffirm their Jewishness in the intimacy of family life, doing so in the most public way imaginable. In this private/public setting, they were human and Jewish at the same time. Precisely this dual quality made them attractive to audiences, who sensed the more universal meaning in the endless stream of family comedies.

The First World War represented as great a watershed for Jargon theater as it did for circus entertainment. It demanded changes in style, content, and most importantly, type of humor. In fact, it is uncertain whether one can really speak of the continuation of Jargon theater entertainment at all after 1916. As nationalist sentiments rose, it became too hard to maintain one of the main leitmotifs of Jargon theater. Community in diversity did not resonate among an audience that, by 1915 , was confronted with chauvinistic war

${ }^{134}$ Bering, Stigma of Names, 21. 
propaganda on all levels. Racist thinking pushed the Jewish community of Germany onto the defensive. Jokes about Jews became intolerable for a community that was not only under siege, but felt abandoned by its leaders. The rise of the Zionist movement - a product of the encounter of German Jews with Polish and Russian Jewish communities in the course of the First World War and the disillusionment with Jewish emancipation and assimilation in Central Europe -- provided one of the most critical voices within Judaism against a theater that had embraced and envisioned a future for an assimilated Jewish community in Germany.

The early 1920s thus saw the end of a genre that had reflected the confidence and optimism of the German Jewish community earlier in the century. By the end of the war, Jews had ceased to define themselves as one of the German "tribes," equally distinct and as accepted as the Bavarian or Bohemian "tribes." Although Jews moved into prominent positions in the realms of politics, the administration and the military -- spheres from which they had been largely excluded prior to 1914 - their confidence in the prospects for assimilation was shaken. Assimilation had not been rewarded with the benefits of social integration and acceptance. The anti-Jewish riots in Berlin's Scheunenviertel in 1923 represented the first climax of an ongoing social disintegration, expressed in a form of street violence that recalled traditional pogroms from the past. As the Weimar years became conditioned by new sensibilities on every front, Jewish performers increasingly turned to other genres of entertainment. 
III Jewish Identities in Revue Theater, 1898-1933 


\section{Chapter 9 Entertaining Berlin's new Elites: The Metropol Theater}

In Berlin, the theater was part of the city's respiratory organs, it was part of its self, necessary like the streets, subways, apartments, and restaurants, necessary like the Spree, the Wannsee, and the Grunewald; necessary like work, factories and Potsdam; just as self-evident.' Herbert Thering

By the first decade of the twentieth century, Berlin had finally awakened and developed selfconsciously into a metropolis. ${ }^{2}$ Its streets ceased to be deserted after dark, and cafés and bars provided refuge for the many night-revelers who, after returning from their visits to Berlin's countless theaters and fairs, refused to call it a night. Revue entertainment attempted to capture this new spirit of mobility, curiosity, and frivolity, giving voice to the seemingly boundless optimism and pride of the upper-middle classes in the pre-war period. Just as Jews contributed to Germany's circuses and Jargon theaters, they were also instrumental to the genesis and the continuing success of Berlin's revue theaters. Jews played a major part in most revue productions. Scripts and tunes were written, composed and performed by Jewish artists, to be presented to a partly Jewish audience. This visible involvement of Berlin's Jewish community in revue entertainment, as both consumers and producers, makes revue theaters yet another compelling arena for the analysis of Jewish identities in German live entertainment.

1 Herbert Thering, Berliner Dramaturgie (Berlin, 1947), 10-11.

2 In the late nineteenth century Berlin experienced exceptional demographic growth. In 1871 932,000 people lived in Berlin; in 1900 there were already 2.7 million, and in 1919 about 3.8 million. Wolfgang Ribbe, Geschichte Berlins: Von der Märzrevolution bis zur Gegenwart (Munich, 1987), 693. 
This section will focus on the most lavish of all revue theaters in Imperial Germany, the Berlin-based Metropol Theater, whose spectacular productions visited most larger German cities and whose theatrical style and music were copied by less prestigious theaters all over the country. The Metropol was the birthplace of the German revue. It was the first theater to introduce to a German audience the Jahresrevue, an import from Paris that focused on the past year's social cultural and political events. Ten revue productions, starting with the revue Neuestes - Allerneuestes in 1903 and ending in 1912 with Chauffeur - in's Metropol!!, affirmed both the leading role of the Metropol in the theatrical scene of Berlin and the importance of Berlin's entertainment industry for the rest of the Reich.

Pre-war revue productions offer particular insights into the relations between Gentiles and Jews in Imperial Berlin. With acts focusing on Berlin's politics, fashion and societal scandals, Jewish characters were commonplace in the Metropol Jahresrevue. When in 1913 the Metropol discontinued its long-standing Jahresrevue in favor of pure production-number operettas (Ausstattungsoperetten), its shows ceased to concentrate on Berlin as their main setting. ${ }^{3}$ Insights into the relations of Gentiles and Jews in Berlin are thus difficult to explore by examining the content and aesthetics of post-war stage productions. The Metropol theater, however, continued to reflect Gentile-Jewish relations. Like circuses and Jargon theaters, its reception as a genre and its importance as a sphere of sociability was affected by the dramatic rise of antisemitism in the aftermath of the First World War. In the early 1920s, the Metropol became the flagship of one of Germany's largest theater trusts, owned and managed by the Jewish entrepreneurs Alfred and Fritz Rotter. The collapse of the Rotter's theater empire in Berlin in the late 1920s triggered a vicious debate about "Jewish dominance" of live entertainment. Thus, offstage, the Metropol theater became one of the main sites of struggles and antagonism in Berlin's post-war entertainment scene.

3 Franz-Peter Kothes, Die theatralische Revue in Berlin und Wien, 1900-1938 (Wilhelmshaven, 1977), 29. 
The Metropol theater was instrumental in the formation of a new elite in Imperial Berlin, which included the upper echelons of Berlin's Jewish community. The formation of this new elite, however, was not uncontested. To the contrary, three years after its opening, the Metropol itself became the venue for one of the greatest societal scandals in Imperial Berlin. In the night of January 4, 1902, exceptional violence and hostility marked a fight among visitors of the annual masked ball held at the Metropol. This was not simply a case of rowdy drunkenness. It was part of an ongoing negotiation abcut who should or should not take the lead in Berlin's social sphere. The inclusion or exclusion of wealthy German Jews was a central issue in this negotiation, however, this episode also illuminates how Gentile-Jewish relations were overlaid and conditioned by other factors such as the rivalries between old and new elites. Representatives of the old Bismarckian elites socialized with wealthy businessmen, agrarians, artists, bureaucrats and representatives of the free professions. All of these factions of society competed to appear on the polished dance floors of the Metropol. In 1902, only three years after the opening of the Metropol theater, these groups found themselves in unfamiliar proximity to each other, a situation that, as this scandal demonstrates, seemed to some, far too close for comfort. It is thus not only significant that the fistfight occurred, but also that it could occur.

Although the masked ball at the Metropol was an exclusive social event, it was far more open to newcomers than most other events organized by the traditional elites of Imperial society. New social boundaries were drawn and old ones reconsidered. The outcome of this process of negotiation was not only significant for the internal dynamics among members of Germany's elite, but also for society at large. The Metropol was not a theater reserved for a small elite only. It was both exclusive and popular, visited by thousands of ordinary citizens, who streamed to the daily shows after the premiere audience had given its stamp of approval. By breaking down the barriers between elite and popular culture, any scandal at the Metropol resonated in middle-class Berlin. The following discussion of the incident itself and its subsequent depiction in the press explores these larger dimensions of the Metropol theater's 
place in Berlin's social sphere. This will set the scene for the ensuing discussion of the importance of Jewish identities for the daily life at the Metropol theater (chapter 10), for its reception by audiences and press (chapter 11), and its aesthetics (chapter 12).

\section{"Skandal im Metropol Theater!" Berlin, 1902}

In the night of January 4-5, 1902, three men -- James von Bleichröder, the Hungarian-Austrian Attaché Count von Schönborn, and the well known amateur jockey (Herrenreiter) Count Königsmark -- convivially welcomed the New Year with streams of champagne, enjoying the splendid evening from their private box at the Metropol's annual masked ball. Just after two o'clock, they must have been as drunk as they were cheerful, and their motor skills had suffered accordingly. While opening yet another bottle, James von Bleichröder, the youngest son of Bismarck's Jewish banker Gerson von Bleichröder, spilled some champagne on the sleeve of a nearby neighbor, who to that point was unknown to him. Enraged by this act of carelessness, the neighbor belted out an antisemitic insult, which infuriated Bleichröder and his company. The Austrian Attaché von Schönborn came to von Bleichröder's defense and demanded the stranger's card, following the usual ritual among gentlemen to settle their disputes through a duel. Instead of complying, the stranger, who was later identified by the police as the mine owner Otto Siegmann, refused. Instead he insulted von Schönborn as well. At this point the Attaché lost control and in the ensuing wrestle knocked Siegmann unconscious. Siegmann collapsed on the dance floor of the Metropol theater, bleeding profusely from the face. Von Schönborn had smashed Siegmann's monocle into countless pieces, cutting his eye in the process. The sight of blood and turmoil led to general confusion and panic among the other guests at the masked ball, and even the intervention of director Schultz could not quiet the tumult. The joyous gathering of the rich and fancy had turned into a 
mob scene, split into two camps: the supporters of Bleichröder and his party, and those of the bleeding Siegmann. Only the presence of the police officers re-established law and order.

In the coverage of this event provided by the Berliner Zeitung, the bourgeois Siegmann is unquestionably identified as the aggressor and von Bleichröder as the righteously infuriated victim. It is striking how the reporter defined the antisemitic insult as un-gentlemanly behavior, emphasizing that even earlier comments by Siegmann's deserved to be reprimanded. ${ }^{4}$ Although disapproval of the extravagant life-style of the wealthy, with all its excessiveness, rings through the report, it is tempered by a respect and envy for wealth and status. Bleichröder's carelessness is presented as a deplorable side-effect of youth which ought to be excused, especially among rich and distinguished men. ${ }^{5}$ Siegmann's transgression, in contrast, was unforgivable because he, a bourgeois nobody, had questioned the status and honor of his noble adversary by refusing to reveal his identity and agree to a duel.

It is significant that it was the noble Austrian Attaché, von Schönborn, who came to the defense of James von Bleichröder. The old elites did not leave Siegmann's transgression uncensored. Schönborn called upon Siegmann to defend himself and, after suffering a personal insult himself, did not shy away from physically abusing Siegmann. By aiming at the eye of his antagonist, he shattered not only his monocle, but his honor. In an era when a gentleman counted the monocle among his essential status markers -- together with his top hat, tail coat, and gloves -- this act was as violent as it was symbolic, effectively punching Siegmann out of the community of tout Berlin. The Berliner Zeitung took notice of this symbolism and rushed to declare Siegmann as an individual of dubious social standing, as someone "who is known to

4 "It seems as if the stranger has already made remarks that deserved reprimand." Brandenburgisches Landeshauptarchiv, 30 Berlin C, Tit. 74, Th. 708, Akt. 138, Berliner Zeitung, January 6, 1902.

$s$ "Personalities are involved in this affair who cannot be denied the right to amuse themselves according to their taste and means, .... to drink champagne and to let loose -- as long as 
entertain direct relations with the less distinguished part of Berlin's demimonde. " The reporter could not confirm this information, but obviously he thought it to be likely enough and sufficiently discriminatory, to have the intended effect on his reader.

The account published in the Berliner Zeitung was confirmed in its essentials by the police authorities. ${ }^{6}$ The police officer, however, had entered the site only after the fight between von Schönborn and Siegmann had already escalated; he therefore identified these two individuals as the main opponents without mentioning James von Bleichröder. The police report did, however, testify to the intensity of the confrontation. The officer stressed the inability of the theater personnel to control the situation and the rancor of the polarized mob. A "regular brawl, fought with rare fierceness" broke out, surprising everybody present by its maliciousness and hate. Eye-witnesses felt compelled to join in the fight: combatants fought with walking sticks and broken champagne glasses. Even Siegmann's serious injury did not have a calming effect on his enemies, who continued to pursue him, as the police officers rushed him out of the building to get medical treatment.

Clearly, then, this fight was more than a gentlemen's disagreement. More was at stake than some champagne stains on a sleeve. James von Bleichröder stood for a generation of young Jews who had attained almost everything their fathers and grandfathers had ever dreamed of. He was young, wealthy, and noble. Instead of embracing an ethos of discipline,

they do not cause any disturbance." Brandenburgisches Landeshauptarchiv, 30 Berlin C, Tit. 74, Th. 708, Akt. 138, Berliner Zeitung, January 6, 1902.

6 "This was the signal for a regular brawl, fought with rare fierceness. Two parties emerged immediately, one supported the Count, and the other fought for Siegmann. They used sticks and threw champagne glasses at each other. Siegmann was punched below the right eye, and the right half of his face swell immensely. The director of the Metropol Theater, Schultz, tried everything to separate the combatants. .... While the injured party was led outside, protected by his friends, his antagonists kept trying to hit him.... Director Schultz ended the turmoil by blocking the doorway after Siegmann had safely left the building." 
hard work, and reason, he was ready to enjoy his extravagant lifestyle. He was not part of the "founding generation" (Gründervätergeneration) who still remembered the times before legal emancipation and who felt that their social advancement depended on their usefulness to Gentile society. Raised amidst abundant luxury, he craved to move smoothly among new and old elites -- a position to which few Jewish families could aspire. ${ }^{7}$ Although Gerson von Bleichröder had not managed to pass his financial instincts and managerial abilities on to his heirs, he had, however, instilled in them his own urge to belong. All three sons of Gerson von Bleichröder were known to have compensated for their ambivalent standing among the rich, noble and powerful with extravagant escapades in Berlin's growing amusement scene. The Metropol was one of the first public arenas that enabled wealthy Jewish men to exhibit their wealth as gentlemen while maintaining their status in Berlin's high society.

The mere presence of James von Bleichröder - the quintessential representative of what antisemites came to call the "jeunesse isidorée" -- provoked Siegmann on that fateful night in 1902. Bleichröder was at once a resented member of Imperial Germany's Bismarckian elites and a pariah, a lord of the manor (Rittergutsbesitzer) and a Jew. Apart from being basely antisemitic, the mine owner Siegmann's response can also be read as the reaction of a disgruntled member of "productive" industry, despising the "unproductive" and immodest Jewish banker. With the expansion of Berlin's entertainment industry, a social arena outside of the military and the court society emerged that provided a meeting ground for wealthy members of the old and new elites. Without having to socialize with the mundane masses, the jeunesse dorée staked out its own territory at the gala dinners and masked balls of the upscale hotels and theaters such as the Metropol. These new social gatherings provided an opportunity for some members of the old elites to witness and participate in the continuous reformulation of tastes

Brandenburgisches Landeshauptarchiv, 30 Berlin C, Tit. 74, Th. 708, Akt. 139, January 5, 1902.

7 Fritz Stern, Gold and Iron: Bismarck, Bleichröder, and the Building of the German Empire (New York, 1977), 492-493. 
and sensibilities of Berlin's high society. Bankers, officers, commercial councilors (Commerzienräthe), Junkers, sports heroes, and entertainment stars met and formed a new elite at the Metropol.

As the dress code at the seasonal ball suggested, this society operated with different codes of distinctions than the court society. In 1902, a new fashionable outfit -- consisting of tail coat, top hat and gloves -- had largely replaced such other status symbols as military uniforms and noble accouterments. It is thus the social diversity, as well as the new codes of honor, that especially attracted journalists' attention. As the following excerpt from Das Kleine Journal reveals, journalists commented on this new social diversity with marked astonishment:

One witnesses a mixing and mingling of all elements of society - those who belong to the respectable society, those who strive to belong, or those who have long abandoned such ambitions, because they have long lost their civic rights. First the men. White tie and tails level all social differences; top hat and walking stick have replaced helmets and sables and conceal whether the portepée and weapon have already started to rust. Aristocrat and carpet-dealer [Teppichnepper], plutocrat and profiteer, gentleman and pimp, sportsman and marketer, artist and con man, Commerzienrath and thief, all gallop peaceably together in search of the game that is called "woman."

The absence of traditional status symbols such as the portepée is particularly remarkable when one considers the pains Gerson von Bleichröder had exerted in 1878 to secure military commissions for his sons. Bismarck had commented on Gerson von Bleichröder's desperation to attain an officer's position for his eldest son Hans. ${ }^{9}$ In 1878 , a military rank was still

8 Brandenburgisches Landeshauptarchiv, 30 Berlin C, Tit. 74, Th. 708, Akt. 141, Das kleine Journal, January 6, 1902.

9 "Bleichröder, who had endured all manner of abuse and denigration, could not envision life in Germany with his son dishonored, deprived of the right to wear a uniform." Hans had previously incensed the crown and jeopardized his chances through his "indecent" behavior. According to Bismarck, Gerson von Bleichröder "would have given his dearest possession -- his first ten million - for a silver portepée." Stern, Gold and Iron, 487; on the importance of the reserve officer in Wilhelmine culture see Eckart Kehr, "Zur Genesis des Königlich 
considered the most secure entry ticket into Imperial society. By 1902, an extended public sphere had emerged, holding out the promise of partial integration, and which did not require such distinctions. Popular entertainment provided an arena of sociability, which blurred distinctions between old and new elites. It also seemed to be meritocratic, letting performers and artists mingle with officers, Junkers and politicians. Wealth - old or recently acquired -- as well as beauty and fame became the decisive factors in the rivalry for attention and distinction in this new crowd.

According to the report cited above, the uniformity of the male dress code was enhanced by the uniformity of their main objective: the "chase" for erotic adventure. The metaphor of the hunt reflected the New Year's ball's function as an occasion that blended the differing status, self-perception and economic wealth of the men who attended. Thus the masked ball had a liberating effect for those who could afford its hefty prices: it was exclusive enough to make it desirable to participate, and catered to the "common" sexual desires and hedonism of those in attendance. Siegmann's transgression, his use of a "vulgar word with a denominational bias," broke the social contract at the Metropol theater. Siegmann, in effect, had introduced an ideologically charged rhetoric where it did not belong, defining the "other" in an arena that consciously advocated its social ambiguity. For this reason Siegmann's action was interpreted not only as a personal assault, but also as an assault on the fundamental claim of popular entertainment to become a new sphere of sociability for Berlin's rich and famous. The Berliner Morgenpost, tellingly, introduced Siegmann to its readers as the "gentleman with

Preußischen Reserveoffiziers," in Das Primat der Innenpolitik: Gesammelte Aufsätze zur preußisch-deutschen Sozialgeschichte im 19. und 20. Jahrhundert (Berlin, 1965), pp. 5363; Hans-Ulrich Wehler, Deutsche Gesellschaftsgeschichte III: Von der "Deutschen Doppelrevolution" bis zum Beginn des Ersten Weltkrieges 1849-1914 (München, 1995), 881-882. 
the inevitable monocle." ${ }^{10}$ As did a writer in the Berliner Zeitung, a contributor to the Berliner Morgenpost thought Siegmann's manners were at fault. ${ }^{11}$ Both newspapers mentioned the academic and the noble title of von Bleichröder and his status as an estate owner. ${ }^{12}$ Siegmann, by contrast, took on the role of the "the stranger" in the reports, without poise, title, or status.

Only a few openly antisemitic papers defended Siegmann's behavior. The Tägliche Rundschau thought that Siegmann had some right to be annoyed at von Bleichröder. After all, it had been von Bleichröder who stained Siegmann's sleeve. ${ }^{13}$ Moreover, the Tägliche Rundschau stressed that even the "philosemitic [judenfreundlich gefärbte]" Berliner Zeitung had to admit that "a member of Jewish high finance [eine jüdische Finanzgröße] had acted provocatively." 14 Taking an "objective" stand, this newspaper did not miss the opportunity to sneer at Jewish members of Berlin's elite circles. The Staatsbürgerzeitung could not agree more. Remaining true to its antisemitic agenda, it saw in the victimized Siegmann the honor of a German gentleman sullied with his own blood by hordes of threatening Jews:

Yesterday morning at about 4 o'clock, scandalous scenes occurred at the masquerade ball at the Metropol theater. A few gentlemen, among them a count known as an amateur jockey, were provoked by the behavior of several Jewish financiers, one of whom was

${ }^{10}$ Brandenburgisches Landeshauptarchiv, 30 Berlin C, Tit. 74, Th. 708, Akt. 138, Berliner Morgenpost, January 7, 1902.

11 "He directed a swear word with a denominational bias at the neighboring box, showing a lack of upbringing. " Brandenburgisches Landeshauptarchiv, 30 Berlin C, Tit. 74, Th. 708, Akt. 138, Berliner Morgenpost, January 7, 1902.

12 Brandenburgisches Landeshauptarchiv, 30 Berlin C, Tit. 74, Th. 708, Akt. 138, Berliner Morgenpost, January 7, 1902.

13 Brandenburgisches Landeshauptarchiv, 30 Berlin C, Tit. 74, Th. 708, Akt. 138, Tägliche Rundschau, January 7, 1902.

14 Brandenburgisches Landeshauptarchiv, 30 Berlin C, Tit. 74, Th. 708, Akt. 138, Tägliche Rundschau, January 7, 1902. 
the heir of a well-known, local bank. A quarrel started and turned violent. One officer was wounded badly in the eye with a walking stick. ${ }^{15}$

In its attempt to defame von Bleichröder, the Staatsbürgerzeitung got its facts so mixed up that it had to officially disclaim its first report. The first report had described the assault of a distinguished officer and gentleman by a Jew. Unfortunately, this did not concur with the actual course of events, since the officer had injured the "businessman S" - a seemingly far less outrageous transgression. To retain its shock value, the article exaggerated the incident even further in its second report: now " 40 Jews and their accomplices ,had injured one upright German citizen. The desperation evident in this newly concocted account demonstrates just how much effort was required by the Staatsbürgerzeitung in order to call into question the status and social standing of Jews in Berlin's high society. This in itself was eloquent testimony to the inroads Jewish citizens had made into Berlin's new elites. ${ }^{16}$

${ }^{15}$ Brandenburgisches Landeshauptarchiv, 30 Berlin C, Tit. 74, Th. 708, Akt. 138, Staatsbürgerzeitung, January 6, 1902.

16 "We have to correct our report on the fist fight at the Metropol theater-ball. It was not the officer who's eye was inured with a walking stick. Instead, it was the businessman S. who was injured by an officer, the Attaché of the Austro-Hungarian embassy. The injured businessman [along with two friends] was originally involved in a fight with the son of a prominent banking house. Forty Jews and their helpers fought against the three gentlemen, one of which was then seriously wounded the eye by the officer and needed further treatment byambulance." Brandenburgisches Landeshauptarchiv, 30 Berlin C, Tit. 74, Th. 708, Akt. 138, Staatsbürgerzeitung, January 7, 1902. 


\section{Chapter 10 Metropolitan Life}

The Metropol theater was vitally important for the development of Berlin's popular entertainment industry. It remained so over several decades, surviving two World Wars, and the initial years of the German Democratic Republic (GDR). Richard Schultz (1863-1928) began this exceptional enterprise when he bought the bankrupt Theater unter den Linden, located on the Behrensstraße in Berlin, and renamed it the Metropol Theater in 1898. An excellent manager, for two decades he directed the Metropol as one might any other large corporation. In contrast to prevailing practice in Jewish circuses or Jargon theaters, neither family bonds nor ethnic solidarity played any visible role in the operation of this theater. Schultz and his silent partner Paul Jentz, both Gentiles, were designated managing directors with permanent five-year contracts. They were guaranteed an annual income of 50,000 Marks plus 1,000 Marks for expenses and fifteen percent of the total profit. ${ }^{17}$ Their main objective was to consolidate their financial success and preserve it in the future. These directors' dealings with staff and audiences reflected this objective. In 1901, for example, Schultz was instrumental in founding one of the first organizations to represent employers' interests in variety entertainment: the Internationale Variete-Direktoren Verband (IVDV) in $1901 .^{18}$

Schultz was concerned to limit his personal risk as much as possible and to find additional sources of income, complementing the daily revenues from the box office. On October 19, 1897 he founded a limited-liability corporation (Gesellschaft mit beschränkter

17 Brandenburgisches Landeshauptarchiv, 30 Berlin C, Tit. 74, Th. 3061, Akt. 224-25.

18 The Metropol theater could not shed this legacy and until 1925, after more than two decades of revue entertainment in Berlin, revue theater were still legally defined as just one form of variety entertainment § 33a of the RGO. Fritz Steidl, "Revue ist Variete," in Das Programm, March 15, 1925; furthermore Konorah, "Revue ist Varieté. Eine folgenschwere 
Haftung, G.m.b.H.) with a basic capital of 400,000 Marks. Twenty-one shareholders were recruited from Berlin's leading financial circles, bankers, lawyers, and entrepreneurs, each buying shares worth between 10,000 and 40,000 Marks. ${ }^{19}$ In 1909, after a decade of success, Schultz and his associate Jentz even converted the Metropol into a joint-stock company (Metropol Theater Aktiengesellschaft Berlin) with a basic capital of one million Marks, divided into shares of 1,000 Marks each. ${ }^{20}$ Unlike the original arrangement, the stocks of the Metropol corporation could now be bought and sold publicly on the stock-exchange. Since the average dividend was over twenty percent in the pre-war period, any investment in shares of the Metropol-Theater Aktiengesellschaft was lucrative for its share-holders.

Some of the shareholders even had a double interest in the Metropol's success. The Jewish clothing manufacturer Hugo Baruch, for example, sought a business affiliation with the Metropol theater to secure for himself exclusive rights to supply the theaters decor and costumes. As a shareholder and as a business partner, Baruch's firm encouraged the most extravagant productions, considerably influencing the aesthetics of the Metropol theater. This influence in part accounted for the prominent place of fashion in the Metropol revues, which never tired of promoting Berlin's fashion industry. Schultz did not care whether his business partners were Jewish or Gentile; instead he followed the business rationale of a market that punished mismanagement quickly and severely.

Richard Schultz's managerial talents were not the only reason for his exceptional success, however. His sense for decor and presentation aiso gave him an edge over other entrepreneurs. He had trained as an actor at the famous Meiningener court theater, where

Entscheidung." in Das Programm, March 1, 1925; documenta artistica collection at Märkisches Museum Berlin.

19 Richard Schultz's personal share was 40,000 Mark. As a regular shareholder of a G.m.b.H. his liability did not exceed his share. Ines Hahn, "Das Metropol-Theater. Theater als sichere Geldanlage," in Ruth Freydank, ed., Theater als Geschäft (Berlin, 1995), 89. 
German drama had undergone experimentation and renewal. With Georg II Duke of SaxeMeiningen as patron, it specialized in historic tragedies and the staging of total pieces of art (Gesamtkunstwerke). ${ }^{21}$ By touring across Germany and even Europe, a new form of director's theater was introduced in most European capitals, which proved formative for an entire generation of directors and theoreticians. Among these were Otto Brahm (1856-1912) and the influential Moscow director Konstantin Sergejewitsch Stanislavsky (1863-1938). Musicians and orchestras were equally influenced by these reforms when they were popularized such well-known conductors and composers as Hans von Bülow, Gustav Mahler (1860-1911), and Richard Strauß (1864-1949). ${ }^{22}$ Schultz's acting experience at Meiningen, his activity as an organizer of touring companies, and his managerial expertise acquired at Berlin's CentralTheater provided him with the versatility of skills that launched him on a path to become one of Germany's most successful theater directors in Imperial Germany. ${ }^{23}$

Schultz imported techniques and aesthetic forms from "serious" drama and applied them to popular entertainment. He thus catered to both to mass and elite entertainment. Whereas the Meiningener company was concerned with the glory of the nation, Richard Schultz tended to celebrate the glory of Berlin. ${ }^{24}$ He envisioned his establishment providing a showcase of the nation's capital. In the program of his opening operetta production, Das Paradies der Frauen (September 3, 1898), Schultz boasted that his whole enterprise stood: "as proud as its magnificent building. In its dimensions, in the grandeur of its interior decoration, it is a house that is truly worthy of the German Empire's capital. It is a metropolitan

Brandenburgisches Landeshauptarchiv, 30 Berlin C, Tit. 74, Th. 709, Akt. 80, Vossische Zeitung, December 1, 1909.

Rob Burns, ed., German Cultural Studies: An Introduction (Oxford, 1995), 12.

22 Burns, ed., Cultural Studies, 14-15.

23 Jelavich, Berlin Cabaret, 105.

24 Alfred Klaar, Herzog Georg von Meiningen: Ein Nekrolog," Shakespeare Jahrbuch, 51 (1915), 93; cited in Rob Burns, ed., Cultural Studies, 15. 
establishment in the true sense of the word." ${ }^{25}$ Schultz wanted audiences to gasp at the Metropol Theater with the colors, sounds, and smells of the metropolis; and by and large, he succeeded. His productions were total pieces of art, stimulating all senses.

It was the celebration of Berlin as a city that accounted for the excellent relations the Metropol management maintained with Berlin's censors. Imperial police presidents such as Trautgott von Jagow and von Glasenapp were personally acquainted with Richard Schultz and his collaborators. In 1909, after his nomination as Berlin chief of police, Jagow even made a point of summoning the scriptwriter Julius Freund into his office, to reassure him of his support. ${ }^{26}$ No doubt, Berlin's authorities took pride in the flattering representation of their capital. Even more than a decade after the last Jahresrevue had been staged, Berlin's Chief of Police von Glasenapp fondly remembered his collaboration with Julius Freund and Richard Schultz, praising the exceptional liberties the Metropol had enjoyed. ${ }^{27}$ Despite that Julius Freund repeatedly complained about the ominous presence of Berlin's censorship authorities, he enjoyed greater freedom than most of his colleagues at less well-connected institutions. Although he mused in a private letter to a friend about the limitations the censors inflicted upon him as an author of satire, the amicable relations between the Metropol and the police left him with considerable creative liberty. ${ }^{28}$

Hahn,"Metropol-Theater," 93.

See Walter Freund, "Aus der Frühzeit des Berliner Metropoltheaters," in Kleine Schriften der Gesellschaft für Theatergeschichte, no. 19 (Berlin, 1962), 62-63; cited in Jelavich, Berlin Cabaret, 110.

27 "I would like to mention for example, the revues at the Metropol theater, which were mounted in utmost harmony between myself, the entrepreneur Richard Schultz and the author Freund, even though at the time it was rather difficult to present political wit and satires - both of which included in those revues -- on stage." Von Glasenapp in Das Organ, 21.1.1928 quoted in Hahn, ,Metropol Theater," 102.

"It is hard to work for an author who, unlike the Parisian caricaturist, cannot simply draw from the chronic of the year, to fill both of his hands with funny events and grotesque 
Only the monumental building of the former Theater unter den Linden could provide the setting for the venture Richard Schultz had in mind for Berlin. Its architectural layout and prominent location provided a glamorous stage for his theairic enterprise. Contemporary visitors unanimously praised the uniqueness of this magnificent site of entertainment. They enjoyed the spacious comfort and the tasteful arrangement of colors and forms, not the least because such aesthetics framed their own wardrobes and costumes in the most flattering way. The new promenoir, in particular -- a foyer behind the seats of the first circle - allowed the audiences to move and mingle freely, just as they might on one of the many grand boulevards of Berlin. Erected in 1872 in grand style, during a period known as the Gründerjahre (founding years), the construction of the theater and supporting buildings had consumed more than 2,300,000 Marks. On a total 6,384 square meters, also sat a grand-cafe, with a capacity of 1,000 seats, and a hotel with 120 rooms. These were connected to the theater by a crystal passageway, that allowed audiences and customers to move freely between the buildings without ever setting a foot outside the amusement complex. The theater itself seated 2,500 spectators. ${ }^{29}$

Beginning with a budget of 200,000 Marks per show -- the Königliche Oper had to be satisfied with 30,000 Marks -- Schultz did not have any trouble recruiting the most outstanding and popular collaborators for his theater. ${ }^{30} \mathrm{He}$ managed to bring together many of the greatest talents in popular entertainment. Religious and ethnic prejudices did not interfere with his choice of partners. Schultz saw himself as the head of a creative team that functioned well only if each of its members was at ease. Julius Freund remembered this collaboration as demanding,

figures. Instead, supervised by the police and pedantic state authorities, he has to work hard to cut the occasional capers!" Ernst Günther, Geschichte des Varietes (Berlin, 1981), 151, quoting Hermann Kaubisch, Operette (Berlin, 1955).

29 Hahn, „Metropol Theater,“ 89-90.

${ }^{30}$ Ingrid Heinrich-Jost, Auf ins Metropol. Specialitäten- und Unterhaltungstheater im ausgehenden 19. Jahrhundert: Ein Kapitel Berliner Kulturgeschichte (Berlin, 1984), 107. 
but egalitarian. Working under constant time pressure, the members of this team seemed to lack the airs one often associates with the realm of theater. The production of each revue followed a set routine, where every member knew his place in the process:

After author and director, in intense meetings, have decided which events and people of the past year will still be remembered even six months after the premiére has passed, they try to frame these people and events in various milieus. While the author retreats to his quiet desk, the offices are turned into a kind of art gallery and hundreds of figures gather.... Once the work of author and director has progressed so far that the structure of the evening is established, the composer joins in. ${ }^{31}$

The "recipe" described above worked to everybody's advantage. Freund, Schultz and Hollaender presented themselves, quite literally, as a triumvirate reigning in the realm of highclass popular entertainment. Discriminating against Jewish performers, writers or composers would have endangered the continuity and success of his company. Because Schultz was a clever businessman more than anything else, interested in his revenues and in his professional status, he seems not to have contemplated or tolerated exclusionary practices directed at his Jewish employees. Schultz's "liberal" attitude towards his Jewish associates was, however, not part of a more comprehensive liberal outlook. To the contrary, he was known for his sexist behavior and his conservative politics. ${ }^{32}$ Yet he remained true to the practices of popular

31 Otto Schneidereit, Berlin wie es weint und lacht (Berlin, 1973), 120.

32 Such a discriminatory attitude towards women was not uncommon in variety or revue theaters at the time, even though it had offended the occasional critic. In 1905, the contemporary writer Eberhard Buchner, for example, denounced such tendencies in Berlin's entertainment industry, writing: "Incidentally, the verses have, at times, a quite misogynist character. It seems as if the man, driven out of his home by domestic quarrels, finds refuge here, and is provided with grist for his mills." Eberhard Buchner, Varieté und Tingeltangel in Berlin (Berlin, 1905), 11. Schultz was known for referring to female dancers and chorus girls as "Menschern," who should be satisfied with their low wages and minimal status in his enterprise. Numerous complaints by members of the Metropol staff, 
entertainment that accommodated ethnic minorities. Schultz hired the Jewish composers Victor Hollaender (1866-1940), Rudolf Nelson (Rudolf Lewysohn, 1878-1960) and Jean Gilbert (Max Winterfeld) to arrange full-scale revues. Their catchy songs reached a broad audience, especially since they were individually published and distributed in print the moment they became a success on stage.

Julius Freund (1862-1914) stood out among this group for having written verses of compelling wit and lascivious timbre, which he combined with mild political satire, ethnic humor or relentless chauvinism. ${ }^{33}$ His rhymes proved to be so successful, that he scripted all of the revues at the Metropol theater. ${ }^{34}$ Freund had inherited his talent for rhymes and verses from his father, Jacob Freund (1827-1877), who taught religion at the Jewish community's religious school. Jacob Freund also wrote numerous poems and was a member of the Breslau Association of Poets (Verein Breslauer Dichterschule). ${ }^{35}$ Despite his rather humble economic status, Jacob Freund was a prominent member of Breslau's Jewish community, well-known as a prolific writer of such religious literature as a reform-oriented prayer book for girls and women, which saw many editions. Occasionally, Jacob Freund even mixed his artistic and religious talents, as in his farce entitled Haman oder die Rechnung ohne Wirth: Posse mit

filed in the archive of the theater police in Berlin, testify to the dissatisfaction among female employees at the Metropol. Schneidereit, Berlin wie es weint, 115.

33 In 1915, after Freund's premature death, the Deutsche Bühnenjahrbuch commemorated him as someone who "possessed the rare ability to present certain contemporary events humorously on stage; to furnish them with funny verses, captivating bonmots, and songs of all kinds." Das Deutsche Bühnenjahrbuch (1915), 168.

34 "Julius Freund, Schriftsteller und Hausdichter des Metropoltheaters zu Berlin gest. Patenkirchen, geb. 8. Dezember 1862 in Breslau. In Patenkirchen, wo er Heilung von einem Schweren Leiden suchte." Das Deutsche Bühnenjahrbuch 1915, 168.

35 For his poems, see Verein Breslauer Dichterschule ed., Album Schlesischer Dichterfreunde vol. 7, (Breslau, 1874), pp. 37-55. 
Gesang in fün Akten. ${ }^{36}$ Inspired by his father, who died when he was only fifteen years old, Julius Freund decided to make his career in the artistic world. At age nineteen he left for Vienna to become an actor. After some acting training, he found employment at the Viennese Burgtheater. He soon realized, however, that he was a more gifted writer than actor, and hence he relocated to Berlin to start his collaboration with Richard Schultz.

Freund's career is illuminating because he represents many other Jewish artists, whose fathers had been cantors, rabbis or religious teachers, and who turned to entertainment. These artists, in effect, exchanged the congregations of their fathers for a theater audience of their own.$^{37}$ Freund's verses were brilliantly delivered by one of the greatest operetta divas of the day: Fritzi Massary (Friederike Massaryk, 1882-1969). As other Viennese stars that chose to perform at the Metropol, this Jewish singer and actress became one of Germany's most celebrated entertainers, universally acclaimed and countlessly imitated. These actors, librettists and composers made up the Metropol's astonishing pool of talent who worked closely with Richard Schultz for almost two decades.

36 Jacob Freund, Gebets- und Andachtsbuch für israelische Mädchen und Frauen (Breslau, 1867); 6th edition (Breslau, 1890); idem, Haman oder die Rechnung ohne Wirth: Posse mit Gesang in fünf Akten (Breslau, n.d) (a copy is in the Jewish National and University Library, Jerusalem). In 1876, just a year before he died, Jacob Freund had an annual income of 2.100 Marks; see his tax records Archiwum Panstwowe we Wroclawiu, Acta miasta Wroclawia, K 150, Bezirk 5, No. 2725. Generally see the obituary on Jacob Freund in Allgemeine Zeitung des Judenthums 41 (1877): 552-553.

37 This phenomena is often discussed in the American context, referring to the exceptional careers of $\mathrm{Al}$ Jolson, Eddie Cantor and Irving Berlin, all three sons of cantors. See Hasia Diner's review of Michael Rogin's book Blackface, White Noise. Hasia Diner, "Trading Faces," in Common Quest. The Magazine of Black-Jewish Relations 2, no. 1, (summer 1997), pp. 40-44. 


\section{The Artistic Staff at the Metropol Theater}

Performers at the Metropol were generally worldly and experienced in their profession. Richard Schultz chose writers and composers whose versatile experiences in other genres or entertainment scenes provided them with a seemingly endless stream of new ideas. Unlike their colleagues in classical music, they did not subscribe to one specific aesthetic form. All of them had already won their first laurels at other music and variety theaters, circuses or cabarets before they entered the Metropol. Their experiences in different entertainment genres made them flexible enough to adjust their own work according to the new trends of the time.

Whereas Freund and Schultz entered the arena of revue theater by leaving "serious" drama behind, Victor Hollaender's artistic development was more eclectic, continuously crossing national and aesthetic borders. As a true cosmopolitan, he traveled extensively and worked for several years in the United States and England, where he performed and socialized with artists such as Al Jolson (The Jazz Singer) and Irving Berlin -- two of the most prominent show stars in America. ${ }^{38}$ Whereas Schultz was impressed by the Meininger Gesamtkunstwerke, Victor Hollaender familiarized himself with spectacular circus shows and music hall entertainment. In 1896, Hollaender was engaged as a conductor at the world-famous circus Barnum \& Bailey, during one of its first guest appearances in London. ${ }^{39}$

Hollaender was only one of many artists at the Metropol who were influenced by circus entertainment, however. The Metropol composer, Jean Gilbert (Max Winterfeld), pursued a similar career before he worked for the Metropol, conducting the orchestra of the Hagenbeck circus. Guido Thielscher was yet another artist at the Metropol theater with prior experience at the circus. As a young man he worked as a clown at the traveling circus before he had his

38 Friedrich Hollaender, Von Kopf bis Fuß. Mein Leben mit Text und Musik (Bonn, 1996), 44-45. 
break-through on the stage. ${ }^{40} \mathrm{He}$ was able to build on his skills as a clown to become one of Germany's most popular performers. His activities in the circus provided him with a great physical flexibility which, in combination with his rather hefty build, predisposed him to physical humor on stage. Both were part of the cosmopolitan world of popular live entertainment in which performers and artists regularly criss-crossed oceans and genres in search of stimulation and employment.

Like the Hermfeld siblings, Victor Hollaender was born into a family of artists. His two brothers Felix and Gustav were important figures in Germany's music scene. Victor Hollaender's wife Rosa Perl was a soprano. His brother Felix worked as Max Reinhardt's dramaturge and as an independent writer of prose and drama. Gustav Hollaender in turn headed the Sternsche Konservatorium, Berlin's most prestigious conservatory at the time. The musical tradition did not end in this generation. Victor Hollaender's son Friedrich (18961976), a musician and composer himself, became one of Weimar Germany's most talented cabaret entertainers. Among his many accomplishments was the founding of one of the first jazz bands in Weimar Berlin, the Weintraub Syncopators, whose special sound could be heard in music theaters and cabarets all over the city. The Syncopators were exemplary of many young Jewish musicians at the time, moving seamlessly among what appeared to be incompatible spheres of life." They played at the festivities of Berlin's Zionist youth organizations, at the jubilees of department stores, Erwin Piscator's revolutionary theater, and at the annual press ball in the Scala.

The artistic world did not pay much attention to the denomination and ethnic background of its participants. Richard Lichtheim (1885-1963), who later became a Zionist

${ }^{39}$ Volker Kühn, Spötterdämmerung. Vom langen Sterben des grossen kleinen Friedrich Hollaender (Frankfurt a. M., 1988), 9.

${ }^{40}$ Berthold Leimbach, Tondokumente der Kleinkunst und ihre Interpreten 1898-1945 (Götingen, 1991), no pages, see article on Thielscher.

41 Hollaender, Kopf bis Fuß, 99. 
politician, remembered how performers were uniquely unmindful of religious and ethnic identities: "This division was suspended only in artistic and literary circles as well as among the people involved in theater. A cosmopolitan society of Christians and Jews socialized at the houses of the painter Max Liebermann, the publisher S. Fischer and Max Reinhardt." ${ }^{42}$ Although these performers often relied on their strong family ties to help promote each other, they socialized outside their own family circles. They knew that professional and private relations worked hand in hand, and reconciling both spheres was indispensable for continuing success. The Gentile Richard Schultz understood that he had to entertain private relations with his Jewish associates, and so he regularly visited their homes. He was intimate with their children, and occasionally he even intervened to help resolve family crises. For example, Schultz once consoled Victor Hollaender's son Friedrich after the latter had had a passionate fight with his father about music. This altercation had been sparked when Victor had modified and integrated one of the first melodies the young Friedrich had ever composed into one of his own songs for the Metropol. Four-year-old Friedrich was outraged at his father's betrayal, and only found comfort after Schultz treated him to a golden coin that, as Schultz did not fail to point out, carried the profile of Wilhelm $\Pi .^{43}$

In Friedrich Hollaender's recollection, most Metropol artists, including the director, exhibited a loyalty to the Emperor, even in the most private setting. The Metropol enjoyed the patronage of the court, despite some of its satirical sketches that criticized crown and fatherland. This patronage applied also to its most prominent Jewish members such as Victor Hollaender. Hollaender, in fact, was well acquainted with the crown prince, who along with his entourage was a regular at the Metropol theater until the First World War. In 1914, during the mobilization of soldiers, this royal connection turned out to be instrumental in Hollaender's attempt to spare his son Friedrich from service at the front. Thanks to the crown prince's

42 Richard Lichtheim quoted in Rürup, ed., Jïdische Geschichte in Berlin, 198.

43 Hollaender, Kopf bis Fuß, 15. 
intervention, Friedrich Hollaender fulfilled his military duties by serving as conductor for a small military theater in the French town of Montmedy, thereby escaping the deadly trench warfare at the Western front. ${ }^{44}$

This incident is representative for the general lack of enthusiasm among more high brow Jewish performers to rush to the front lines. Unlike Jewish circus performers, they felt no need for an extraordinary effort to profess their loyalty to crown and fatherland by serving in the more deadly theaters of war. To the contrary, many sought exemption in order to "work" the home front. The more famous these entertainers were, the more likely they were to win such exemption. Well acquainted with high-ranking officials, among Berlin's old and new elites, they felt more secure in their overall standing in society at large. Instead of making their "Jewish contribution" to the war effort, they sought other means to express their loyalty to king and country.

While Hollaender enjoyed the patronage of the crown prince, Rudolf Nelson, another of the four eminent composers at the Metropol, even managed to establish a personal rapport with the emperor himself. Born Rudolf Levysohn to a poor Jewish family from an eastern neighborhood of Berlin, Nelson demonstrated his musical talent at an early age. He began as a musical "child prodigy" in the ballrooms on the Alexanderpiatz. His parents, however, feared the uncertainties of an artistic existence, and forced him to take a position in the textile trade. After a number of unhappy years there, Nelson left for the Sternsche Konservatorium in Berlin. He eventually became a student of Gustav Hollaender, a relationship that soon extended to the entire Hollaender clan. Through the intervention of Gustav Hollaender, Nelson won the financial support of three Berlin bankers, which allowed him to shift his focus from serious music and drama to popular entertainment. Nelson became known as a versatile impresario, composer and pianist. Through the mediation of his actor friend Maria Sulzer, he was

44 Ibid., 65-66. 
introduced to Prince Joachim Albrecht, an art fanatic and an ardent fan of popular music. ${ }^{45}$ This acquaintance was Nelson's entry ticket into Potsdam's court society and Berlin's elite circles. ${ }^{46}$ An outstanding performer and a gifted businessman, Nelson introduced Berlin's high society to its first glamorous cabaret the Roland von Berlin, which catered exclusively to the carefree and wealthy. In 1908, the Kaiser was so taken with one of Nelson's songs, which inevitably focused on "indecencies" in one of the chambres separées, he summoned him for a private show to his hunting quarters at the castle of Prince Egon zu Fuerstenberg in Donaueschingen. ${ }^{47}$ As Peter Jelavich has pointed out, this particular incident incensed the public, because it occurred while the Kaiser was facing one of the greatest crises of his regime: the Daily Telegraph affair. ${ }^{48}$ Wilhelm II seemed oblivious to the fact that his public image was further diminished by his search for frivolous distraction at a time when a distinguished and statesman-like appearance was called for. Like Victor Hollaender, Nelson was also in close contact with the crown prince, who was one of his Duzfreunde. Despite his great success with the Kabarettrevuen in the Weimar years, he continued to be a monarchist at heart. ${ }^{49}$

A defining element of the Metropol theater was its troupe of star actors: Fritzi Massary, Joseph Giampietro, and Guido Thielscher. The success of Fritzi Massary eventually surpassed that of her colleagues. Even in 1927, twenty-three years after her debut in Berlin, tourist guides and intellectuals were unanimous in their judgment of Fritzi Massary's exceptional presence on stage. ${ }^{50}$ The Jewish actress Fritzi Massary was the subject of countless contemporary essays and biographies. Her elegant presence and her timeless charm caught everyone's eye. Born as

45 Klaus Budzinski, Die Muse mit der scharfen Zunge: Vom Cabaret zum Kabarett (Munich, 1961), 87; also Jelavich, Berlin Cabaret, 95.

46 Egon Jameson, Am Flügel: Rudolf Nelson (Berlin, 1967), 58.

47 Jelavich, Berlin Cabaret, 99.

${ }^{48}$ Jelavich, Berlin Cabaret, 99-100.

${ }^{49}$ Budzinski, Muse mit der scharfen Zunge, 91-92.

${ }^{50}$ Eugen Szatmari, Das Buch von Berlin (Munich, 1927), 112. 
a Viennese businessman's daughter, she was known for her work ethic and managerial qualities, being one of the first self-made women ever to gain fame in Germany. Celebrated as the queen of German operetta, and as an innovative artist in popular entertainment, she elevated revue and operetta to previously unknown heights. She was one of Germany's first international stars. A Massary premiere was the unquestioned high-point of any season, and as the contemporary writer Eugen Szatmari ironically advised the reader of his alternative tourguide through Berlin, "one had to petition in order to buy tickets. ${ }^{\text {51 }}$ Fritzi Massary was famous for her ironic delivery, which gave even the most profane line a mystical depth. This talent allowed her to be more daring than most actors without being harassed by the censorship authorities. It was her aura of amorality and professionalism that made her a role model for such later stars as Marlene Dietrich. ${ }^{52}$

Fritzi Massary was able to master any accent demanded of her: some say she adopted and discarded dialects like different sets of clothes. As one of the most versatile actresses of the time, she was able to play several characters in one evening, a talent that proved to be crucial for her career in revue theater. Unlike her male counterparts Joseph Giampietro (1866-1915)

5I Szatmari, Buch von Berlin, 90. For a discussion of Fritzi Massary's success, see Elisabeth E. Bauer, "Fritzi-Massary -- eine Frau die weiß was sie will," in Siegrun Anselm and Barbara Beck, ed., Triumph und Scheitern in der Metropole. Zur Rolle der Weiblichkeit in der Geschichte Berlins (Berlin, 1987).

52 Oscar Blumenthal's review of Fritzi Massary in her last appearance on a German stage reveals what she has meant for her German public. Blumenthal praised her for being the ideal to which all women in her generation aspired, indeed, the personification of exquisite taste. In his review of Oscar Straus' Eine Frau, die weiss, was sie will, Blumenthal wrote: "Nobody who ever saw Fritzi Massary on stage will deny her the right to be counted among the first ladies of this epoch. She has ceased to be an individual. She is the dream of the cultivated sisters of her generation; the impersonation of good taste in a time which seems to have lost it in so many other areas. Massary does not just play a role, she does not appear and leave again, she is not just a good actress or operetta diva. No, Massary is omnipresent, 
and Guido Thielscher (1859-1941), Fritzi Massary was not cast in only one type of role. She could impersonate an Empress or "sin;" she could be comical or dramatic, as the scene demanded. Whereas Giampietro always played a snobbish gentleman and Thielscher always the clumsy commoner, Fritzi Massary had many faces. ${ }^{53}$ She became whomever her audiences wanted her to be, and this talent, embodying her public's dreams, guaranteed her success throughout her long acting career. She was the only female star at the Metropol to achieve such status. $^{54}$

It is significant that, despite her acclaimed flexibility, Fritzi Massary hardly played a Jewish role in her entire career at the Metropol. Nevertheless, in this choice she was no exception. In fact, Jewish actors mainly avoided to impersonate Jewish characters at the Metropol theater. It was the Gentile actor Guido Thielscher who specialized in Jewish roles; and it was Thielscher who first delivered the popular song: "Hab'n Sie nicht den kleinen Cohn gesehn? " In many way this song was a tribute to Thielscher's Jewish roles at the Metropol theater. On stage he was the incarnation of the "small Cohn.": a comically ordinary man who, with a mixture of brave cleverness and naive ignorance, mastered the trials and tribulations of life. "Cohn" was mischievous and amicable in the same time; he was lacking in manners and composure. All of these attributes made him the perfect side-kick to his actor friend Giampietro, who had rather too much of those qualities that Thielscher lacked. Thielscher provided the perfect foil to the snob, Giampietro. When Giampietro was bored, Thielscher got

she is the artistic consciousness, the living memory, the image of regeneration, and youthful hope. In short: she is a symbol of art itself."

53 "Director Schultz recognized the uniqueness of the actor who was able to satire elegance as well as to represent the funny bonvivant in any Metropol theater revue." Das Deutsche Bühnenjahrbuch (1915).

${ }^{54}$ In popularity she could be matched only by Elisabeth Bergner, another young Jewish actress whose star began to rise in the Weimar period and whose acting career continued even after she had gone into British exile in 1933. 
excited. When Giampietro posed as the sophisticated gentleman or the dashing officer - a favorite of all women -- Thielscher's own effort at courtship inevitably failed dismally.

While Jargon theater performers and circus artists still felt part of a community, Jewish artists at the Metropol theater did not. They were individualists whose loyalties to a milieu or enterprise were mostly motivated by professional considerations. Jewish performers employed at the Metropol theater were among the most assimilated Jews in popular entertainment. They conversed in High German, were generally secular, often entered into mixed marriages, and moved comfortably within Berlin's high society. These entertainers could not retreat to the comfort of a predominantly Jewish community the way circus entertainers or even actors in Jargon theaters were able to do. Entering the realm of revue theaters, they seemingly left the community behind, and had to make decisions as Jews in a predominantly Gentile environment. Each day, these performers had to determine if and how their ethnic identity should inform their private and professional lives; yet most of them never confronted their Jewishness publicly.

\section{The Social Composition of the Audiences}

Until the First World War, the Metropol theater was designed to entertain the emerging new elites in Imperial Germany, catering to what contemporaries called "Tout Berlin." Richard Schultz and his colleagues managed to gather the rich and the successful at the Metropol, as well as anybody who wanted to appear as such. In their venture to define themselves, these new elites turned to the theme of Berlin as a focal point of their identities. Celebrating the metropolis on stage allowed Berlin's new elites to gain a renewed self-consciousness in a rapidly changing environment. Schultz sensed the need of German urbanites for such specificity when he named his new enterprise the "Metropol theater." By making the city the centerpiece of every production, he in turn helped to create an image for his upscale audience. 
Spectators were not only reminded of major and minor events in Berlin circles, and what to wear for the season, but also who was part of the in-crowd in Imperial Berlin and who was not. The Metropol helped these new elites to define their boundaries, promoting an unprecedented degree of self-consciousness among its audiences. Because these boundaries were constantly in flux, the Metropol created a continuing need for its revues. One day's celebrated Jahresrevue already legitimated the next.

The self-conscious attempt to remain up-to-date resonated through the Metropol theater's frequently self-referential performances. For example, one of the main songs in the revue, Das muss man sehn!, caricatured what one member of Berlin's in-crowd might look like. This song was meant to amicably summarize the necessary attributes of a Metropol spectator, who, as the title revealed, had to be a stroller of the Kurfürstendamm, the grand boulevard in the fashionable western part of Berlin:

The people of Kurfürstendamm:

There is in Berlin a small circle,

Which calls itself Tout Berlin,

Where everybody knows something about the other;

Where everybody knows everybody else,

Whoever has, whoever can,

Who calls himself, comme il faut,

From the Tiergarten district,

from around the Zoo,

And the people from Kurfürstendamm,

All together, all together! $!^{5 s}$

This first stanza of this song described the requisite living quarters for a representative of "Tout Berlin." The Zoo, the Tiergarten and the Kurfürstendamm were fashionable recreation areas

${ }^{55}$ Landesarchiv Berlin, Metropol theater, Das muß man sehn, 1907, Rep. 30 c/a, Theater Z, Neuer Teil. For original see Appendix 10, see pages 297-98. 
situated in the prosperous districts of Charlottenburg, Wilmersdorf and Schöneberg. All of these areas shared a unique social make-up, that set them apart from other city districts. First and foremost, they were residential areas with an exceptionally high concentration of upper middle-class Jewish families. ${ }^{56}$ Whereas poor Jewish newcomers tended to settle close to Jewish institutions in the eastern parts of the city, the established Jewish community concentrated in Berlin's western and south-western neighborhoods. ${ }^{57}$ This trend had begun as soon as Berlin's Jewish community began to prosper in the late eighteenth century, and it continued until the 1930s. ${ }^{58}$ Contemporaries remembered that it was difficult to find a house without a Jewish family in the exclusive Hansaviertel, in the Tiergarten district, and in the "Bavarian quarter." 59 The demographic distribution according to city districts shows that even in $192513 \%$ of the population in Wilmersdorf was Jewish, $10 \%$ in Berlin-Mitte, $9 \%$ in

${ }^{56}$ In $1905,21.4 \%$ of German Jews lived in Berlin (130,487 individuals). The Jewish community of Berlin in turn amounted to $4,8 \%$ of Berlin's total population. The Jewish community was not at all distributed evenly across the city, however. In 1933, the greatest desity of Jewish residents was found in Charlottenburg with 27,013, then Wilmersdorf, 25,607, then Mitte 24, 425, then Prenzlauer Berg 18,051, then Schoeneberg 16, 261, then Tiergarten 12,286. Rürup, ed., Jüdische Geschichte in Berlin, 308.

57 Rürup ed., Jüdische Geschichte in Berlin , 192.

58 Gabriel Alexander, "Die jüdische Bevölkerung Berlins in den ersten Jahrzehnten des 20. Jahrhunderts: Demographische und wirtschaftliche Entwicklungen," in Rürup, ed., Jüdische Geschichte in Berlin, 122.

59 "There are no statistics for the actual number of Jews living in the Hansaviertel and their percentage of the population at large. One can conclude, however, that their number must have been high, since every house accommodated at least several Jewish families." This was the recollection of Werner Rosenstock, a lawyer and a member of the Zentralverein der deutschen Staatsbürger jüdischen Glaubens, who was born in Berlin in 1908. Quoted in Rürup ed., Jüdische Geschichte in Berlin, 193. 
Charlottenburg and 6\% in Tiergarten. At this time, Jews represented approximately $4.5 \%$ of Berlin's total population. ${ }^{60}$

The presence of established Jewish families was noticeable and left its mark on the street life and ambiance of these quarters, without, however, giving them a ghetto character. ${ }^{61}$ On high holidays, Jews were visible on the Kurfürstendamm, streaming in great numbers to the grand synagogue on the Fasanenstraße, walking in close proximity to other Berliners, who in the mean time admired the displays in the windows of West Berlin's exclusive shops. As the song above implies, these neighborhoods - Wilmersdorf, Charlottenburg and the Tiergartenviertel - were not marked by the usual anonymity of a big city. Instead their inhabitants were integrated into rich social networks. Residents of all these districts were known to identify strongly with their neighborhood. But it was a certain kind of identification nonetheless, stressing these quarters particular flair, wealth and social mobility, captured in the first stanza of the song. Thus the Metropol celebrated those neighborhoods in which Gentiles and Jews were rich together, forming what contemporaries called tout Berlin.

Who is at dinners, at soupers,

One meets again and again?

Who shines in all committees

With their signatures?

Who can be found at the Tatternsaal

And at the five o clocks?

Who can one salute at the ball of the press, At Nikisch, at Siegfried Ochs?

And who promenades cozy and happy

At a summer's evening out at the "Zoo"

${ }^{60}$ Gabriel Alexander, "Die Entwicklung der jüdischen Bevölkerung in Berlin zwischen 1871 und 1945," in Tel Aviver Jahrbuch für deutsche Geschichte 20 (1991), 287-314.

${ }^{61}$ For residential concentration of Jews in Berlin, see Udo Christoffel, ed., Berlin Wilmersdorf. Die Juden. Leben und Leid (Berlin, 1987). 
In the gossip-avenue with hullabaloo and tantara?

Yes, all all all all all are there ${ }^{62}$

The second stanza defines the leisure activities of the residents of West Berlin. The spectators were advised where to socialize if they wanted to be part of tout Berlin. All the above mentioned locations and activities, the popular concerts ("Niekisch and Siegfried Ochs"), grand hotels ("five o'clocks"), the promenades ("Lästerallee") were well known, though recently established, areas of Gentile-Jewish encounters. These encounters were thus facilitated through the opening of such "contact zones" outside the classical cultural canon. In addition, the song included references to Berlin's city politics and its countless local organizations and committees. Berlin's Jews were known for their active involvement in charity organization, educational committees and other associations that fostered the interest of Berliners at large. This strong involvement was at least in part an outcome of Berlin's Jews' specific professional profile, concentrating in the spheres of commerce and the free professions. Both occupational sectors demanded a high degree of public involvement to succeed. ${ }^{63}$

By 1907, the term tout Berlin had permanently established itself in Berlin's public discourse. The Vossische Zeitung,- for example, was confident that its readers would be familiar enough with the social profile of the "Berliner premiere audience" that it did not have to mention exactly who appeared in smoking jackets and evening gowns. In the early years of the Metropol's existence, most reports of its performances or balls provided a detailed description of the visitors' professional occupations, age, ethnic origins and status. By contrast, only five

${ }^{62}$ Landesarchiv Berlin, Metropol theater, Das muß man sehn, 1907, Rep. 30 c/a, Theater Z, Neuer Teil. For original see Appendix 10, pages 297-98.

63 For occupational patterns of Berlin's Jewish community, see Alexander, ,Jüdische Bevölkerung Berlins,“" 130-136. 
years later, journalists confidently referred to "Ganz Berlin," without feeling any need to go into greater detail. ${ }^{64}$

Despite its up-scale aura, the Metropol theater could not afford to rely on the support of elite circles alone. It also had to attract a middle-class audience anxious to imitate and mingle with tout Berlin. While the premieres and the annual masked balls were not affordable for the masses - ticket prices rose steadily, reaching up to 300 Marks by 1910 -- the subsequent 250 300 performances of the Jahresrevuen were certainly within reach of middle-class Berliners, ranging from 1.50 Mark for a standing room ticket, to 10 Marks for a theater box. ${ }^{65}$ To be sure, participation at the annual masked ball and at the premiers of the revues determined who did and did not belong to the in-circles of Berlin's elites. Nevertheless, the hundreds of subsequent showings of the respective Jahresrevuen served to tout the ins and outs of a new elite to a wider public. Tourists attended glamorous shows to see and be seen, eager to claim their right to a few hours of vicarious fame.

The Metropol theater not only catered to specific social groups in Imperial society, it also had a gendered agenda. To a far greater degree than did the circuses or Jargon theaters the Metropol attracted a specifically male clientele. Men ran the show at the Metropol, and other men determined its success. The Metropol theater was a male sphere, designed to entertain the young and adventurous gentlemen of Berlin's high society. Although women participated on stage and as spectators, they remained confined to the roles of sexual objects and willing

64 "Yesterday was a big day for the Metropol theater, and in extension for Berlin's premier theater audience. Yet another annual revue by Freund was staged - an event which mobilized "Ganz-Berlin." The entire auditorium was filled with ladies in precious evening gowns and gentlemen in the equivalent suits." Brandenburgisches Landeshauptarchiv, 30 Berlin C, Tit. 74, Th. 714, Akt. 313; Vossische Zeitung, September 15, 1907.

${ }^{65}$ See for a discussion of the price inflation at the Metropol theater the Berliner Morgenpost, September 7, 1910. 
consumers of the latest fashion. ${ }^{66}$ Especially the conservative press exhibited this bias, in the meanings it attached to the presence of male and female spectators.

In 1904, for example, the journal Deutsche Warte included a description of how male and female visitors to the annual masked ball at the Metropol presented themselves. Although the author concedes that the male visitors were all drawn from the "best social circles," including army officers, artists, lawyers, judges, and bureaucrats, he was doubtful whether the same could be said of female visitors. Obviously, women risked their reputation when they entered the realm of revue entertainment in fin-de-siècle Berlin. Taking a conservative perspective, the author was particularly startled by the indiscriminate mixing of individuals at this festive occasion. Old and young, married and unmarried men, Jews and Gentiles, representatives of the army, the navy, the stock market, the court, the arts and the press -- all of these types mingled with what the author identified as thinly disguised prostitutes. Whereas the author argues that the presence of gentlemen guaranteed the genteel character of the merry event, he ironically remarked upon the lack of embarrassment of some of their wives to show themselves in such company: ${ }^{67}$

One cannot claim that these ladies belong to the highest circles of society. Rather, as some insiders have confirmed, the majority of them are frequent visitors of our elegant ball houses. Numerous respectable wives mingle among them with no sign of

${ }^{66}$ In 1898 , the Vossische Zeitung symptomatically considered " the main attraction of the Metropol the spectator's opportunity to make "not uninteresting anatomical studies." Brandenburgisches Landeshauptarchiv, 30 Berlin C, Tit. 74, Th. 714, Akt. 18, Vossische Zeitung, September 4, 1898.

67 "The balls at the Metropol Theater are always a high point because the male visitors are drawn without exception from the highest social circles. Their presence guarantees that despite all the gaiety and merriness, and despite the consumption of streams of champagne, the distinguished character of the festivities does not suffer." Brandenburgisches Landeshauptarchiv, 30 Berlin C, Tit. 74, Th. 708, Akt. 213, Deutsche Warte January 4, 1904. 
embarrassment. They insist on accompanying their husbands into the seductive merriness -- be it out of curiosity or out of prudent caution. ${ }^{68}$

Unlike circuses or Jargon theaters, the Metropol theater not only tolerated, but actively encouraged, prostitutes to seek out the theater in their search for clients. The Metropol management went out of its way to facilitate the "amorous adventure" of the visiting Kavaliere; it even adjusted the architectural design of its facilities to that end. The promenoir, for example, gained some notoriety, because it allowed potential clients discreetly to approach prostitutes in the theater. Salons, chambres separées and an American bar provided even more private settings for intimate encounters. Director Schultz knew that he would lose much of his male clientele if he were to deny prostitutes' access in his establishment. Hence they were allowed to enter the theater after 9 o'clock for a token cover charge of one Mark. The presence of prostitutes was part of the overall appeal of the Metropol. Clearly, then, the management was aware that the consumption of hard liquor and champagne depended on the creation and nurturing of such a scene. Since Berlin's city politics did not restrict the access of prostitutes to public buildings, the management of the Metropol was not likely to take the extra step of restricting their presence in the theater.

What is particularly significant about the Deutsche Warte's negative assessment of the Metropol's female visitors was that the author mentioned the presence of Berlin's wealthy Jewish youth only in passing. Although the press release referred to the so-called "jeunesse isidorée," the antisemitic label for the Jewish segment of Berlin's Lebewelt, it did not take the opportunity to further sneer at the Jewish visitors of the Metropol. Using the term "jeunesse isidorée" the author half-heartedly warned his reader that all that glistens is not gold; but then he quickly proceeded to offer a positive assessment of the theater's decor and the extravagance of the visitor's costumes. Apparently, even this conservative and antisemitic critic grudgingly

${ }^{68}$ Brandenburgisches Landeshauptarchiv, 30 Berlin C, Tit. 74, Th. 708, Akt. 213, Deutsche Warte January 4, 1904. 
accepted the mingling of upper-class Jews and Gentiles. Berlin's Jewish upper-middle class had permanently established itself as an essential part of the Metropol audiences. 


\section{Chapter 11 The Metropol and its Critics}

In 1898, the Berliner Lokal-Anzeiger greeted the transformation of the Linden-Theater into the Metropol-Theater as a move away from an ill-fated classical theater towards a "site ready to host gaiety and superficiality." The report described director Schultz as a thoroughly modern theater director who "instead of turning art into pleasure, turned pleasure into art." The report continued its double-edged praise by offering an assessment of the Metropol staff's creative potential. Similar to the general reception of the Hermfeld brothers, the Berliner LokalAnzeiger acknowledged the competence and originality of the director and his script writer, by pointing out that their talents would have achieved recognition even in the realm of "serious drama": "This man [Schultz], who through dogged energy and restless work knows how to translate his imaginative ideas into sparkling reality, he would also prove his extraordinary director's talent solving real artistic tasks." The author continued by deploring the misguided talent of script writer Julius Freund emphasizing that Freund too would have been able to hold his own in a "higher form of art." Giving voice to the more conservative factions of Berlin's society, the Berliner Lokal-Anzeiger, although impressed by the pomp on display at the Metropol's opening, still eyed the theater with reservations. ${ }^{69}$

In 1903, only four years later, the Metropol theater had managed to gain a broad range of public approval. Through their work at the Metropol, Jewish entertainers, writers and composers found a degree of public esteem that performers at Jargon theaters could never attain. Not only Richard Schultz was credited for this success: the Metropol's main composer Victor Hollaender and its librettist Julius Freund also became celebrated public figures in the entertainment scene. Even the Staatsbürgerzeitung pointed to the exceptional support Schultz's enterprise enjoyed among a broad array of newspaper critics. Its report from 1903 confirmed 
that director Schultz could hope for the "benevolence of Berlin papers of the most diverse political orientations." ${ }^{\prime 70}$ Despite its antisemitic orientation, the Staatsbürgerzeitung did not mention that both Hollaender and Freund were Jewish, as was a considerable part of the Metropol theater's audiences.

The right-wing press and avant-garde critics alike credited the Metropol with a unique ability to capture the spirit of the time. Even influential left-wing critics such as Herbert Ihering, who began his career at the Schaubühne and in later years continued to write for the Vossische Zeitung and the Berliner Börsen-Courier, embraced the Metropol theater as an indispensable part of the Big City. Although Ihering was known more for his critiques of modern drama and radical writers such as Bertholt Brecht than for his support of mainstream popular entertainment, he remembered the pre-war Metropol as a crucial component of Berlin's unique atmosphere in the pre-war period. ${ }^{71}$

In the pre-war period, the Metropol and Berlin's new elites were bound together in a symbiotic relationship from which all parties profited. It was its unquestioned centrality in the urban landscape of Berlin that made the Metropol a meeting place of Berlin's prominent citizens. The Metropol did not merely transmit the values authorities and old elites wanted to be communicated to society at large. The friendly relations between police authorities and the Metropol theater were not symptoms of a slavish relationship between popular entertainment

69 Brandenburgisches Landeshauptarchiv, 30 Berlin C, Tit. 74, Th. 714, Akt. 16, Berliner Lokal-Anzeiger, September 4, 1898.

70 Brandenburgisches Landeshauptarchiv, 30 Berlin C, Tit. 74, Th. 714, Akt. 205, Staatsbürgerzeitung, January 7, 1903.

71 "Besides the leading, representative stages, there were others which did not belong any less to Berlin and its lively, optimistic power. [Among those others,] the Metropol Theater staged those satirical-musical revues which summarized last year's political, literary, fashion, societal and folksy sensations in a worldly manner." Ihering, Berliner Dramaturgie, 13. 
and social elites. It was an honor to be mocked in a Metropol revue, and even the crown prince was flattered by such public exposure.

\section{The War and its Aftermath}

During the war, the Metropol lost its dominant position in Berlin's entertainment scene. Revue entertainment ceased to be a specialty of the Metropol theater alone. It became the most common form of amusement in Berlin, enjoyed by thousands of spectators in countless theaters. These Ausstattungsrevuen exceeded the already lavish pre-war Jahresrevuen at the Metropol theater in length, personnel and decor. Although the Metropol was known for its optimistic and future oriented revues in the pre-war period, it escaped into a dream world of the past in the post-war period. While some directors sought to attract spectators into their shows by presenting the famous kick-lines of girls marching on stage like a perfect human machine, the Metropol specialized in saccharine Viennese operetta, and in revues calculated to recall the "good old times." Jewish identities and the relations of Jews and Gentiles did not figure prominently in their post-war revues and operettas. The question of Jewish integration and the rise of antisemitism did, however, play an increasing role in the perception of the Metropol as a cultural institution.

After the war, the Metropol theater experienced an almost complete turnover in management and personnel. Changes that began during the war were completed in 1918 . The Metropol theater had suffered from the economic distress in Germany. Like most theaters, it closed down in August 1914, reopening its doors four month later with the patriotic show Woran wir denken - Bilder aus großer Zeit. This production reflected the general conviction in December 1914 that a quick German victory was still to be expected, even though it might demand more sacrifices than previously anticipated. Touting verses such as "Hoch soll die Fahne schweben, die Fahne schwarz-weiß-rot!/ Wir geben Gut und Leben, wir fürchten nicht 
den Tod!," the Metropol contributed its share to the war propaganda effort. This message did not, however, find the resonance director Schultz had hoped for. ${ }^{72}$ After initial enthusiasm for the war among the German population had given way to a rather gloomy determination to survive, Schultz decided simply to close the theater for an indefinite period. In fact, the Metropol did not play again until 1918, when Richard Schultz left the theater and retreated to his estate in Bavaria. He was to die very shortly after. Schultz had directed the Metropol for almost twenty years and grew tired only when his successful team of collaborators vanished. Julius Freund and Joseph Giampietro had died in 1914/16. Others either retired or were lured away by the expanding cabaret scene and by competing revue theaters.

In 1927, Schultz's silent partner Jentz had to declare bankruptcy. The post-war inflation had hit the Metropol corporation particularly hard, and its shares lost much of their value. Moreover, the general impoverishment of Berlin's spectatorship had prevented the Metropol from regaining its sound financial footing. The Viennese operetta entertainment introduced by the new director, Fritz Friedmann-Friedrich, never enjoyed quite the same unanimous public approval. The loss of local flair on stage led to a loss of the Metropol's longstanding support even among its most devoted fans. The dramatic decline of the Metropol was extensively covered in Berlin's press, which interpreted its demise as yet another symptom for the general malaise in German society. In 1927, the journalist Alois Munk writing for the Berliner Lokal-Anzeiger suggested that Berliner's diminished sense of local pride had much to do with the decline of the Metropol: "Das Metropol-Theater, das früher selbst diktiert hat, ließ sich diktieren. Von einem Markt, der weitab lag und seine Masse von anderen Menschen nahm. " The report continued by describing the pre-war Metropol revue's lost glory: " Das Metropol-Theater war lange das berlinischte Theater, das der Stadt den goldumrahmten Spiegel

${ }^{72}$ Schneidereit, Berlin wie es weint, 186. 
vorhielt und ihren berauschenden Rhythmus einfing. "73 This exalted past was a faint memory in 1927 when two Jewish entrepreneurs, the Rotter brothers, entered the story.

When Fritz and Alfred Rotter (Schaie) bought the Metropol theater, adding it to the many theaters in Berlin they already owned, this transaction was unanimously interpreted by Berlin's critics as marking the bankruptey of Berlin's theater scene. Creative ambitions had lost out in favor of mere economic considerations. Disenchanted journalists summed up this development with the slogan, "In Berlin geht die Kunst heute nach Brot." ${ }^{14}$ Post-war crises had resulted in the collapse of numerous theaters in the capital. The purchase of the Metropol completed the trend toward the concentration of theatric enterprises in the hands of a few entrepreneurs. The Rotter brothers took advantage of the crisis in the market and bought many theaters in Berlin and its vicinity, alarming Berlin's press and police. By 1924, they owned the Residenz-, Trianon-, Zentral- and the Kleine Theater. The Berliner Börsen-Courier, one of the most important voices in the cultural sphere, claimed that "businessmen and outsiders, carpet dealers, theater agents, and clerks" had entered the cultural realm in search of quick profit. ${ }^{75}$ The Rotter brothers and their profit-oriented business practices were blamed for this negative development. The paper thus called for a "war" against the brothers, who it thought to be the "prime culprits in the decline of the theater scene. ${ }^{176}$ The anti-capitalistic rhetoric of the Berliner Börsen-Courier had a familiar ring by 1927, reminiscent of the populist agitation of German antisemites in their crusade against "Jewish Manchesterism" during Germany's first industrial

${ }^{73}$ Brandenburgisches Landeshauptarchiv, 30 Berlin C, Tit. 74, Th. 2375, Akt. 74, BerlinerLokal-Anzeiger, August 6, 1927.

${ }^{74}$ Das kleine Journal, December 18, 1927.

75 "Besorgnisse und Vorgänge im Theaterbezirk. Kämpfe gegen die Rotter-Konzession," in Berliner Börsen-Courier, July 17, 1924.

76 "Besorgnisse und Vorgänge im Theaterbezirk. Kämpfe gegen die Rotter- Konzession," in Berliner Börsen-Courier, July 17, 1924. 
boom in the nineteenth century. However, even the Deutsche Bühnengenossenschaft did in fact call the Rotters on their "profitmäßiges Manchestertum."

In stark contrast to their predecessor Schultz, the Rotters were considered to be outsiders to the realm of culture and refinement and even Jewish critics and performers pointed to their idiosyncratic style and dubious ambitions. The Jewish entertainer Paul Morgan, for example, in a column in the $8-U h r-A b e n d b l a t t$, pointed out how protectively the Rotter family managed its theaters. According to Morgan, no stranger was allowed to assume any key position in the business. ${ }^{78}$ Morgan also described the business practices of the Rotter clan, as akin to the stereotype of the ,haggling Jew." Implicitly, Morgan suggested that the Rotters could not tell the difference between horse-trading and theater:

Just a few month ago everybody laughed at the customer service at the box office of the Residenz theater. When someone approached the ticket counter looked disgruntled at the prices, and turn away grumpily -- Daddy's clever head would immediately appear in the window, asking the undecided customer: "How much do you want to invest?" No one could resist such mischievous conduct, for everyone engaged in negotiations. ${ }^{79}$

Morgan may actually have intended to characterize the Rotter family as a clan of good-natured schlemiels. He did not attribute any ill-intent to their behavior, but thought that their mercenary actions simply reflected their nature. By describing them as Ostjuden, Morgan distanced himself from these cultural entrepreneurs. Fritz and Alfred Rotter did not originate from Eastern Europe, however. They were born in Leipzig where they studied law before they

${ }^{77}$ Brandenburgisches Landeshauptarchiv, 30 Berlin C, Tit. 74, Th 2959, Akt. 37; „,Der Fall Rotter vor der Bühnen-Genossenschaft, “ in Der Tag, July 20, 1924.

78 The numerous family members of the two Rotter gentlemen can be found in any part of the trust. At the Residenz, Trianon-, Zentral- und kleinen Theater the brother controls the sister, and uncle Rendant screams when the brother in law at the box office wants to cut a deal with the cousin secretary." Paul Morgan, "Wissen Sie schon...?" in 8-Uhr-Abendblatt, July 19, 1924.

${ }^{79}$ Paul Morgan, "Wissen Sie schon...?" in 8-Uhr-Abendblatt, July 19, 1924. 
discovered their taste for the theater. That they were not immigrants from the shtetl, is something that Paul Morgan should have known as a well-informed critic of Berlin's cultural scene. Morgan seemed to have been unaware that his depiction of the Rotters fed into antisemitic stereotypes that decried the increase of "foreign influences" on German culture. In his own way he contributed to a hostile climate in which the Rotters functioned as a lightning rod, accused of "economic exploitation" and "the prostitution of German art and culture." They continued to play this part until their deaths. Their public exposure in the cultural realm condemned Alfred and Fritz Rotter to be among the first Jews in the entertainment industry attacked and murdered and driven into suicide by the Nazis in 1933.

Although performers seem not to have adjusted to the increasing hostility towards Jews in public during the 1920s, their Jewish audiences displayed a greater sensitivity to the portrayal of Jews on stage. In 1926 the Zentralverein deutscher Staatsbürger jüdischen Glaubens, the single most important organization representing the interest of Jews in Germany, called upon its members to protest against Jewish jokes in cabarets and theaters. The Zentralverein felt these jokes posed a threat to the integrity of all Jews. In the rhetoric of the old liberals, the Zentralverein decried antisemitic depictions of Jews and Jewish traditions on Berlin's stages, calling for the support of "all righteous people irrespective of social standing and religion." 80

This declaration resonated widely in the German press and was also commented up on in the professional journals of cabaret, circus and variety performers. Das Programm devoted its front page to the question of attempting to respond to the Zentralverein's allegations. The

80 "We protest against the vicious ridiculing and mindless distortion of the Jewish character, and Jewish institutions in a series of Berlin's theaters and cabarets. No Jews with honor and dignity shall support such dubious art. The assembly requests from the Zentralverein to engage with all its might in a battle against degeneration at cabaret and theater. The Zentralverein can be assured of the help of all righteous thinkers disregarding their social 
author of this response, Dr. Allos, agreed that Germany's present hard times demanded humorous entertainment that should not of fuel the flames of racial hatred, but instead should defuse social tensions. ${ }^{81}$ The author pointed out that most comedians who specialized in Jewish jokes were Jewish themselves. Furthermore, he insisted that those members of the audience who were most enchanted by such performances were Jews as well. But there lay the problem. Allos was convinced that "Gentiles were not able to understand the many "Jargonausdrücke" often represented the punch line of these jokes. Allos concluded that the continuation of such jokes were undesirable for both Jews and Gentiles: "such incomprehensible expressions - partly laughed at as jokes -lead to the erection of invisible barriers between Jews and Gentiles, barriers which are particularly unappreciated in the cabaret."

Although it is doubtful whether only Jewish comedians presented Jewish jokes, Jews certainly did not refrain from telling such jokes. To the contrary, as we have seen, Jewish performers were involved in the creation of a "Jewish image" on German stages. Living in a social environment that was not markedly receptive to antisemitism, the sensibilities of Jewish artists towards ethnic discrimination seemed to have been far less developed than those of their Jewish audiences. Although they were not oblivious to social tensions, Jewish artists thought the best way to deflect them by was distinguishing sharply between the assimilated Jewish community in Germany and eastern European Jews. The frequent use of Yiddish on stage suggests that most jokes attributed all form of misbehavior to the eastern European segment of

standing and religion!" Quoted in Dr. Allos, "Der Protest gegen jüdische Witze im Kabarett," in Das Programm, May 30, 1926, no. 1260.

81 "Especially today, at a time poisoned with hate, we have to avoid any poison that instead of healing, may provoke yet greater crisis. A good joke shall relax hate and human passion, instead of adding to them. "Dr. Allos, "Der Protest gegen jüdische Witze im Kabarett," in Das Programm, May 30, 1926, no. 1260.

${ }^{32}$ Dr. Allos, "Der Protest gegen jüdische Witze im Kabarett," in Das Programm, May 30, 1926 , no. 1260 . 
Berlin's Jewish community. Berlin's Jewish audiences, on the other hand, felt more and more unease with the depiction of East European Jews on stage, fearing any association with the potentially negative image of the Ostjuden. 


\section{Chapter 12 Aesthetics}

"What is a revue? A revue is ... when there is no plot ... and décor and costumes cost a million. ... What should a revue be? A witty series of disconnected scenes that satisfy the eye, the ear and the mind. These scenes should mock our everyday life, and, on the side, provide racy singers, cute dancers, clever Don Juans and quick-witted comedians the opportunity to blow away the gloom of our days with good humor, guts, rhythm and dashing nonsense." 83 - Fritz Grünbaum, 1925.

This was how the Jewish writer and conferencier Fritz Grünbaum (1880-1941), who began his career in Rudolf Nelson's cabaret Chat Noir, once described "revue."84 The upbeat energy and jovial tone of this definition reveals Grünbaum's enthusiasm for a dramatic genre that was to revolutionize Germany's entertainment industry.

The celebration of modernity was a major theme at the Metropol theater with special emphasis on Germany's new consumer culture. Spectators were presented with an endless display of fashion, sex and sports, with a little politics and local gossip thrown in for good measure. To date, Peter Jelavich's study Berlin Cabaret has provided the best overview of the content and style of these revues. As Jelavich pointed out, the Metropol revue "considered itself an up-to-the-minute chronicle of metropolitan life, a sort of Berliner Illustrierte Zeitung brought to life on stage. ${ }^{185}$ From its inception, the Metropol's director had sensed variety's enormous potential. While some contemporaries were still deliberating the merits of variety entertainment, the Metropol had already adopted its winning formula. In short and loosely

${ }^{83}$ Fritz Grünbaum in program, "Die Hölle," Revue "Rund um den Mittelpunkt" (Wien, 1925) quoted in Franz Peter Kothes, Die theatralische Revue in Berlin und Wien, 1900-1938 (Wilhelmshaven, 1977), 14.

84 The Nazis murdered Fritz Grünbaum in the Dachau concentration camp in 1941.

85 Jelavich, Berlin Cabaret, 106. 
connected scenes or skits, lined up like the products in one of Berlin's modern department stores, the Metropol revue touted the qualities of Warenhaus Gross-Berlin to a highly attentive audience. $^{86}$

The art of pleasing all and offending none was one of the greatest strengths of the Metropol. The press never tired of calling attention to the Metropol's capacity to unify a diverse audience with its Jahresrevuen. As one reviewer wrote in the local boulevard journal Die Nacht auf Montag (1907):

The challenge of offering something for the tireless revelers of all ranks, classes and races, for the lieutenants and for the brokers, for the agrarians and for the Jews, for the teenage girls [Backfische] and the aunts, for the respectable world and the demimonde, is a task on whose successful execution the interest of a huge capital [Anlagekapital] depends -- the box office sales of an entire year. This challenge has been met once again. $^{87}$

The Metropol revue Das muß man sehn!, staged in 1907, was typical for the genre. Two characters, Commère and Compère, took the audience through various scenes and provided a loose plot-line for the show. These two characters were archetypes rather than specific individuals, approximating allegorical figures such as Morpheus, "sin", and Lucifer. They might even representatives of a particular event or social group. In the revue Das muss man sehn!, Compère represented a conservative Junker from East Elbia, whereas Commère or "Fräulein Freisinn" was drawn from the liberal camp. Their antagonistic political and ethical views spiced their continuing dialogue and provided a thread through the show. Nevertheless, their romantic involvement as newly-weds served to prevent any one group among the audience from feeling rejected. The spectator was reassured that despite continuous quarrels

${ }^{86}$ Jelavich, Berlin Cabaret, 116.

${ }^{87}$ Brandenburgisches Landeshauptarchiv, 30 Berlin C, Tit. 74, Th. 714, Akt. 314, Die Nacht auf Montag, September 16, 1907. 
between Commère and Compère, it remained "all in the family." Even such antagonistic groups as the agrarians and the Jews could enjoy the Metropol revues together.

To mediate between ideological camps and social groups was a major objective of Das muss man sehn! The script-writer Julius Freund juxtaposed two groups -- Jews and antisemites -- which he thought to be, and his audience knew to be, irreconcilably hostile. To take the edge off this touchy subject, Freund designated two child characters to represent the antisemitic and Jewish milieus: one was the son of a well-known antisemite, Count Pückler; the other was the daughter of one of the Hermfeld brothers. In the course of the conversation between Compère/Commère and the children, the spectator learns that the latter had been interchanged for six months a period, each to live with the other's parents. Freund conducted a kind of "scientific experiment," by exchanging two children from very different ethnic, political and social backgrounds. The rural, traditional, elitist Gentile met the urban, Jewish, liberal parvenu. This exchange and its wider implications, illuminates a key idea of this revue. Socialization, and not biological predisposition, determines attitudes and behaviors.

In the following scene, the two children meet for the first time since their exchange. Their different impressions and experiences constitute the substance of the play's message, roughly as follows: While taking a stroll through Berlin, Commère and Compère first stumble upon the young Pückler. Not shy, the boy surprises them with his uninhibited attitude towards adult strangers, as well as with his noticeable "Jewish" accent, syntax and behavior:

Boy: Who's that [jenne]?

Compère: What does 'that' [jenne] mean?

Boy: Well - there - that little schickse [Schickselchen], you Gannew!

Compère: That is my wife you rascal.

Boy: Oi! Oi! Oi! How lucky some people are! You tell all Jewish children! You! You have to take good, good care of that, there are nibblers out for that!

Commère: We are on our honeymoon.

Boy: I know! I know Everything! We children are taught about Everything in pre-school already! That is the modern way! 
Compère: You interest me mostly, because you are an exchanged child.

Boy: That's right, that's right. The way you have just met me, for example, you will be very surprised when you hear who I am.

Compère: Well, my lad, who are you?

Boy: I am the son of Count Pückler. ${ }^{88}$

Speech patterns, vocabulary and attitude were meant to evoke the image of a "typical" Berlin Jew. Throughout this brief exchange, the boy interspersed various Yiddish terms, all of which had become part of the local Berlin jargon. This was a practice also employed by Jargon theaters à la Herrnfeld. By mockingly calling Compère a gannew, the Hebrew term for thief (ganew), the boy immediately created an inappropriate intimacy with the adults. Their unease was heightened by his reference to Commère as a Schickselchen, the Yiddish label for a nonJewish girl, which had acquired a derogative connotation in Berlin jargon. Both transgressions proved him oblivious to the sensibilities of respectable Berlin society, which he further provoked by precociously emphasizing his familiarity with sex education. Within a few sentences, the boy with a "slight Jewish accent" revealed himself as an unruly member of Berlin's Jewish subculture. Every Jewish stereotype was employed to convince the spectator of the authenticity of this young man. He was loud, lacking the most rudimentary social graces, and sexually mature, all of which were considered common attributes of Jews in Imperial society -- but he was not Jewish.

Scene 8 further emphasized the incongruity between the behavior and social origins of the boy. He acted like the very caricature of a Jew. He was interested in the price and quality of garments (Berlin Jews were supposed to "control" Berlin's garment industry). He was also cheap, trying to cut a deal wherever an opportunity arises (haggling prices was another trait commonly attributed to Jews in the German folklore). He lied, and instead of being ashamed made a virtue out of his vices. He was easily excitable and talked incessantly and randomly,

${ }^{88}$ Landesarchiv Berlin, Metropol Theater, Das muß man sehn! 1907, Rep. $30 \mathrm{c} / \mathrm{a}$ Theater Z, Neuer Teil. For original see Appendix 11, pages 298-99. 
mixing crucial and unimportant information. Finally, he denounced his biological father for uttering antisemitic Schmonzes, (the Yiddish term for rubbish (schmonzess)), and praised his "step-parents," the Herrnfelds, for their contribution to German folk culture or Heimatkunst, as he called it:

The little Pückler: (a funny boy in a sailor's suit, slight Jewish accent):

That went well! I told the man at the box office that I am still under ten years old and he gave me a children's ticket. No, no! Why should I be embarrassed! What does the man need to know that I already celebrated bar mitzvah?

Compère: That fellow interests me. Good day, kid.

Pückler: Why kid? Who are calling kid? How can I help you?

Compère: You interest me, because I have been told that you are an exchanged child.

Pückler: That's right, that's right. I am an exchanged child! For a few months, we children are nowa' days always exposed to a totally new environment, completely different from our own, so that our Ponimkreis [outlook] is broadened.

Compère: What circle?

Pückler: Well - Ponimkreis! Horizon, if you understand that better.

Compère: May I ask how old you are?

Pückler: (touches Compère's suit) Great fabric that you have there. What did you pay per meter?

Compère: I would like to know how old you are.

Pückler: Ten years -- to a hundred!

Compère: That is a vague answer - a little more precise please.

Pückler: Well I told you - ten to a hundred.

Commère: You have to ask differently. How old towards a hundred years are you?

Pückler: Ten years, You see, that's how it's asked.

Compère: And where are you off to?

Pückler: Where am I going?

Compère: Strange, that you always answer a question with another question!

Pückler: Why, am I asking? By the way, if you are really interested, I am going to KleinTschirne!

Compère: Whaat? Klein -Tschirne??

Pückler: Yes, I have been luckily boarded for healthy six months as an exchanged child by the brothers Herrnfeld. 
Compère: Boy, boy, I believe your daddy will burst with anger when he sees you again like this.

Pückler: So what! He bursts - he bursts! I don't believe in those antisemitic Schmonzes anymore anyway. I even met the red Manasse and he is a very nice and decent man, let me tell you. And every evening I went to my foster parent's theater! There I was introduced to -- what is known as -- Heimatkunst!!

Compère: And in the meantime - if I understand correctly -- the little Hermfeld girl was sent for further education to Klein -Tschirne?

Pückler: A very modest gal indeed! I am very curious how she has broadened her horizons. ${ }^{89}$

Julius Freund was confident not only that the audiences would understand the occasional Yiddish words woven into the idiosyncratic speech of the young Pückler, but also that they were familiar with Jewish rituals and traditions. Barmizwe, for instance, the rite of passage for Jewish boys, was mentioned without further explanation. To understand the discussion about the boy's age in the scene, the spectator had to be aware that this ritual was celebrated at each boy's thirteenth birthday. Clearly, Freund thought that familiarity with the rituals of Jewish life in Germany was part of the common cultural canon, and therefore needed no further explanation.

The reference to the red Manasse in the preceding scene was further proof of the fluidity of German-Jewish culture, being part of a defined subculture as well as of the mainstream. Manasse was a play written in 1900 by Aaron Blumenfeld, a left-wing Rumanian Jew. It was translated into Yiddish, German and English, but more importantly it was made into a popular movie. As the film historian J. Hoberman argues, this movie was not strictly speaking a Yiddish film, although it included common Yiddish terms to appear authentic. ${ }^{90}$ Manasse argued that Jewish assimilation was inevitable, while taking a sympathetic stand

${ }^{89}$ Landesarchiv Berlin, Metropol Theater, Das muß man sehn! 1907, Rep. 30 c/a Theater Z, Neuer Teil. For original see Appendix 12, page 299-301. 
towards traditional Jewish life. Both the play and the movie dealt with themes of mixed marriage and religious conversion, depicting the costs of both for European Jewry. Manasse became a reference point in popular culture, addressing the question of Jewish identity and integration in the Diaspora. Obviously, Ahron Blumenfeld's piece was known in the circles of assimilated Berlin Jews as well. ${ }^{91}$ The Metropol audience must have been sufficiently acquainted with the content of the piece to understand Count Pückler's vexation over his son's socialization with a character who stood for mixed marriages and Jewish integration.

Freund was confident that the majority of the spectators would be sufficiently familiar with Jargon theater to understand and appreciate the allusions to the Herrnfeld brothers, two icons of popular Jewish theater. In this dialogue he imitated one of the staples of Jewish humor as presented in the Gebrüder Herrnfeld Theater, assuming that it would be recognized beyond the boundaries of Berlin's Jewish subculture. When asked a specific question, the "Jewish" character always replied with a question himself, considerably complicating what might have been uncontentious issues. Even in seemingly serious conversations, the Jewish hero injected random observations into the conversation, as if his inner voice spoke out aloud. Herrnfeld characters, too, loved to play with the meaning of words and images. "Jewish wit" itself stemmed from these linguistic origins. Being asked a question, the character often responded to the literal meaning of a word in a context that demanded its abstract meaning. Of course, the mixture of Yiddish "Jargon" and High German proved to be a winning combination. The "little Pückler," for example, confronted Compère with the word Ponimkreis (field of vision). Not only was Compère unfamiliar with the word Ponim, the Yiddish term for face (ponem); but its use in connection with the German word Kreis (circle) served to complicate things even further. The educated German middle classes despised such creative mixing of languages and dialects. It was, however, the source of much amusement in Jargon theater. 83. 
Although it relied on Jewish stereotypes that were common among the upper classes, the Metropol's intention was not to ridicule all Jews. This would have alienated a large segment of its audiences and performers. Thus it was the antisemite's son who epitomized the halfassimilated, hand-waving Jew. By overstating the image of a "Jew," Freund's play ridiculed the image itself. Moreover, in order to evenhandedly mock the entire social spectrum, Freund not only harped on Jewish stereotypes, but also painted a similarly satirical picture of German antisemites. In Scene 9, for example, Rosalie Hermfeld, the Jewish daughter of one of the Herrnfeld brothers, experiences a change of heart equal in magnitude to that of the young Pückler. Having spent the past six months in Klein-Tschirne at the estate of Count Pückler, she has developed a taste for horseback riding, one of the most popular pastimes of a noble landowner. She loves the excitement of hunting and despises the "sickening" city. Rosalie used health metaphors, interchangeably denouncing the physical and social ills of the city. She has acquired the anti-modernist rhetoric of the ultra conservatives who compared society to an organism, constantly involved in a fight against the corrupting influences of foreign "germs." She walks and talks in a military style, demonstratively waving her whip; her answers are brief and concise, articulated in a commanding, masculine diction. In such exclamations as Donnerwetter or skandalös, she captures the manner of an agrarian lord as neatly as when she uses the whip. Thus in Scene 8 the playwright manages to present a stereotype that is no less persuasive than the Jewish one:

Hermfeld: (enters very smart, with riding whip, etc., etc.)

Donnerwetter noch mal, what luck that I finally arrived in Berlin! Throughout the entire trip I was crammed in with a bunch of salesman and sale's representatives! A scandal, how these strangers flirted with me.

Pückler: That's her, that's her!

Compère: If I am not entirely wrong, I have the pleasure --

91 Hoberman, Bridge of Light, 84. 
Herrnfeld: Miss Herrnfeld, Rosalie Herrnfeld, daughter of the brothers Herrnfeld, as exchanged child for six months at Pückler's at Klein-Tschirne (towards the boy) Good day Teut! German handshake!

Pückler: Hello Salchen, you really look very good.

Herrnfeld: I did not miss a thing out there with your old man, in the fresh and beautiful country air. I positively envy you! Now you can go hunting again!

Pückler: Why me? Sharks go hunting!

Hermfeld: You can ride attacks again!

Pückler: No! No! I was at the Herrnfelds for six months -- I'll never mount a horse again!

Hermfeld: And I will miss all those nice and funny evenings, where your daddy thundered down from the podium until the man in blue put on his hat and dispersed us. Pückler: You won't miss anything, your people also speak from podiums (and are pretty fine comedians too) [censured in the text].

Compère: I see with pleasure that the system works splendidly and that the young ladies and gentlemen have filled the gaps in their characters in a truly wonderful way. ${ }^{92}$

After spending only six months on the Pückler estate, Rosalie Herrnfeld has become imbued with a violent prejudice against foreigners and commercial travelers, all of whom she suspects of being Jewish. She automatically assumed that they approach her with "bad intentions," seeking erotic adventures wherever they go. She talks in the inflated language of a hypernationalist, greeting Pückler's son with a "German handshake." She has also developed a taste for the cavalry, envying the boy for his opportunity to hunt game on the estate of his father. Rosalie, in short, had taken on the airs that supposedly come with a noble birth, looking down upon commoners who must work to survive. Her concerns are those of an estate owner who has nothing but leisure activities to occupy his or her mind. In addition, Rosalie has fond memories of public antisemitic rallies, at which Count Pückler has given violent speeches. As she pointed out herself, these speeches were so outrageous that even the Imperial police were forced to intervene and to dissolve the meetings. Freund's depiction of Rosalie Herrnfeld is 
thus no more flattering than his characterization of the "semitic" young Pückler. In many ways, however, these two children appear surprisingly similar: they are each other's alter ego. The amicable way they relate to each other suggests that they find themselves at two ends of the spectrum, that spectrum bent full circle, so that they meet in the end.

To fully appreciate the content and meaning of this revue, one must look beyond the boundaries of popular entertainment. For in 1907 an extraordinary coalition was conceived between the liberal and conservative camps. In the years before 1906, after serious disagreements over colonial and military issues had arisen between the Reichstag and the government, Chancellor Berhard von Bülow had dissolved the Reichstag and called for new elections. Held in January 1907, those elections dramatically altered Imperial Germany's political climate. Bülow orchestrated a coalition of all national parties, including the leftliberals, to form a patriotic, anti-clerical, and anti-socialist bloc. ${ }^{93}$ This tactic turned out to be successful in the short run: the block parties won 220 out of 397 seats in the Reichstag. ${ }^{94}$ Bülow took great pride in this new coalition of more or less antagonistic parties, celebrating the bloc as "the merging [Paarung] of the conservative with the liberal spirit." To those Germans inclined to wishful thinking, the bloc promised to end the exclusion of the middle classes from political power. ${ }^{95}$

Thus we see that the spirit of reconciliation and cooperation dominating the revue Das muß man sehn! was no accident. Rather, it was an explicit and faithful reflection of the contemporary political climate. Taking Bülow's call quite literally, and playing with the double meaning of Paarung, the Metropol married the conservative with the liberal spirit by presenting the agrarian (Compère) and Fräulein Freisinn (Commère) as newlyweds. Political struggles

92 Landesarchiv Berlin, Metropol theater, Das muß man sehn, 1907, Rep. 30 c/a Theater Z, Neuer Teil. For original see Appendix 13, page 301-302.

${ }^{93}$ Thomas Nipperdey, Deutsche Geschichte, 1866-1918 (Munich, 1992), 730.

94 Nipperdey, Deutsche Geschichte., 731.

95 Nipperdey, Deutsche Geschichte, 732. 
were thus transformed into domestic quarrels between husband and wife. In the process, the ideological antagonism between liberal Jews and conservative antisemites was relativised and ridiculed. In Julius Freund's script, the sympathetic Compère states that the exchange of children had led to mutual understanding. He seems confident that a mere exchange of positions will lead to the desirable fulfillment of each individual. He does not take sides in his depiction of the social groups the children represent, however. Both children are ridiculed playfully; their officious righteousness is even touching. As we see in the following dialogue between Compère and Commère in Scene 11, the play ends with appeal for world peace and harmony:

Commère: Well what do you say about these two fine specimens?

Compère: I don't find it all that silly? If the exchange continues as it is - between countries and estates -- little by little, many prejudices and many barriers have to fall and soon it will be just a step towards general understanding, towards world peace! ${ }^{96}$.

In this final dialogue, the Metropol theater implicitly articulated its own role in bringing about harmony and peace. Compère calls for the disappearance of all prejudices - between countries, and between estates. Keeping open avenues of communication and facilitating the exchange of ideas would lead to a new understanding in national and international politics. To facilitate such an exchange was one of the objectives of Das muß man sehn! To please everybody was thus not only politically opportune and economically rewarding; it was also a programmatic objective of the Metropol theater. Julius Freund, in collaboration with Richard Schultz, consciously downplayed the gravity of political and cultural conflicts by using actors playing children for their skits. Education of the whole person and exposure to new environments led to the complete transformation of these impressionable children. The suggestion was clear: no antagonism in German society was too great to overcome.

${ }^{96}$ Landesarchiv Berlin, Metropol Theater, Das muß man sehn!, 1907, Rep. 30 c/a Theater Z, Neuer Teil. 
At this time, prior to the First World War, performers and entrepreneurs engaged in theaters and cabarets were conspicuous in their belief that an international cultural exchange worked to everyone's personal advantage. Many representatives of the cultural sphere felt that with the expansion of the entertainment scene, new roles and responsibilities had arisen for all cultural institutions. In 1909, for example, actors and directors joined forces with businessmen and scientists to raise funds and public support for an English-American theater in Germany. As the Vossische Zeitung reported on February 23, 1909, this theater was destined to enhance the cultural exchange between nations. The promotional material stated that "the bridging of national differences and the peaceful convergence of people was the aspiration of all civilized nations [Kulturstaaten]." 97 The organizer of this initiative hoped to provide an example. The theater would once again become "the school of the nation." This philosophy simultaneously legitimated the desire of the modern entertainment industry to expand its sphere of influence. With the revue Das muß man sehn! the Metropol theater, as one of the leading theaters in Germany, asserted its own claim to be part of this new movement.

Das muß man sehn! was not the only revue in which Julius Freund introduced Jewish characters on stage. In fact, virtually every Jahresrevue included at least one scene with Jewish characters. In 1909, for example, the already familiar Compère and Commère encountered another caricature of the "modern" Jew in Hallo!! Die große Revue. There the couple took a tour around the city, eager to explore for themselves how much Berlin had acquired the flair of a true metropolis. Among other sites of amusement, they visited Berlin's fashionable race tracks. Soon a " funny little man" attracted their attention. He hastily introduced himself as an employee of the so called ,rental-company-for-human-beings“ (Menschenverleihungsgesellschaft G.m.b.H.). In the following dialogue, the stranger, who

${ }^{97}$ Brandenburgisches Landeshauptarchiv, 30 Berlin C, Tit. 74, Th. 1469, Akt. 1, Vossische Zeitung, February 27, 1909. 
later refers to himself as the "elegant Isidor," explained to the bewildered couple the nature of his services:

The gentleman : I am a rented gentleman! Outstanding employee of the newly founded rental-company-for-human-beings Ltd., Berlin. Tasch-Tasch (wants to leave)

Compère: One moment! That's extraordinarily interesting! You are for rent then? The gentleman: Just like a noble title, the title of a Kommerzienrat, like the red Order of Eagle! Do you find anything wrong with that? Tasch-Tasch! A very distinguished profession! I've just returned from my morning shift in Moabit where I am always rented as a witness.

Compère: What do you do there then?

Gentleman: I swear.

Commère: Swear? What exactly?

Gentleman: Whatever is necessary! Anything wrong with that? ${ }^{98}$

The conversation revealed that the stranger operated like a human chameleon. He made his living by facilitating modern urban life, appearing at court in case a witness is wanted. He was oblivious to the fact that his activities transgressed both ethical codes and civil law. Playing with the double meaning of "verleihen," which could mean either to lend or to award, he compared his activity to receiving one of the highest decoration, of Imperial society, the red Order of Eagle (Adlerorden) and a noble title. Implicitly the spectator is reminded of the meaninglessness of such distinctions, whose value had been diminished by Wilhelm II's excessive patronage practice. ${ }^{99}$ The spectator, initially disenchanted by the stranger's corruption, found himself reminded of the hollowness of Imperial Germany's honor code. In the ensuing dialogue it became clear that the stranger was the incarnation of other people's sham existences, their guilty conscience, their imperfect lives. As the scene unfolds it becomes

98 Landesarchiv Berlin, Metropol Theater, 18.10.1909, Hallo!! Die grosse Revue, Rep. 30 c/a Theater $Z$, Neuer Teil 4559.

99 Alastair Thompson, "Honors Uneven: Decorations, the State and Bourgeois Society in Imperial Germany," in Past and Present 144 (1994): 171-204. 
obvious that the stranger does not have a criminal mind. Being asked to elaborate on his occupation he hesitates, then continues:

Gentleman: [...] For dinners and soirées, when a fourteenth person is needed or a dancer. ... The Leysohns on Stralauer street engage me for every reception merely to show that they have elegant Christian acquaintances. Do you mind that? ....

Commère: It is understood that you must posses the most sophisticated aristocratic manners.

The gentleman: What a joke! The elegant Isidor is the adornment of every salon. I do not spit on the floor, I do not burp at the table and I only pinch my table neighbor in the calf when it is explicitly required. ${ }^{100}$

As his elaboration demonstrates, the stranger refined his area of specialization to serve the needs of Berlin's Jewish upper middle-class, whose members are concerned with its integration into society at large. The stranger emphasizes his social skills as if to assure the listener that his own successful assimilation into bourgeois society has been completed. He understands it to be his job to bring about the same for his clients. In the ensuing exposition it turns out that the stranger did not accomplish this task with unanimous success. Encouraged to elaborate on his own past, he admits having received rather mixed reviews from his employer. In fact he failed utterly in his attempts to become an impeccable gentleman. His memories begin to tumble over each other as an endless series of mishaps, rather like a slapstick comedy. As the scenes described gain their own momentum, they finally reach a climax in physical humor that is clearly designed by the librettist Julius Freund to leave the audience in stitches of laughter:

The gentleman: That damned ass of a hired servant poured the entire sauce down my dinner partner's neckline and since I didn't have any sauce left myself, I dipped my asparagus. Tantara! Anything wrong with that? And I will never forget that disastrous evening at the Kohns just recently. When I came in, Mrs. Kohn told me that I had been

${ }^{100}$ Landesarchiv Berlin, Metropol Theater, 18.10.1909, Hallo!! Die grosse Revue, Rep. 30 c/a Theater Z, Neuer Teil 4559. 
hired to dance, but only with the Missniks, so they would not be peeved. "Very well" I said, and headed straight for the biggest Menubbl in sight, whereupon Mrs. Kohn almost fainted - that was the bride! Tata! To calm my agitation, I hurried to the buffets and ate six portions of ice-cream. Then Mr. Kohn yelled : "Take more care and less ice-cream, I hired you to be a dancing bear, not a polar bear!" This rudeness affected my stomach and made the ice-cream rebel, I weakened and unfortunately in front of the entire party I went .... Commère: Good Lord!

Compère: You went where??

The gentleman: Let me finish, let me finish. I went and sat down on a woman's hat that I had not noticed in my stupor. Anything wrong with that? Tata!"101

Freund's take on Jewish identities does not lie far beneath the surface in this scene. The more excited the stranger becomes, the more he lapses into a "Yiddish jargon." Many contemporaries believed the Jews to have a particularly excitable and nervous nature; a stereotype that is played up again and again in Metropol revues. This idea was often combined with the conviction that assimilated Jews would involuntary reveal their "real" origins on such occasions of excitement, waving their hands and reverting into their "own" slang; a process which was caricatured in the above cited scene. Yet, Julius Freund gave this scene a highly ironic spin by mocking both the Jewish stereotypes that circulated among Gentiles and the insecurities of the Jewish community, which led to over-compensation. In this way he was able to appeal to his Gentile and his Jewish audiences in the same scene. This dual approach could be found in other revues too, where the playwright caricatured not only the Jews who tried but failed to assimilate, but also those upper-class Gentiles who fostered exaggerated and ridiculous Jewish stereotypes.

The struggle of Germany's Jews to belong was a theme that recurred on a regular basis in Metropol revues. One last example demonstrates yet another variation on this theme. In this scene the fashion industry is the arena in which German Jews meant to prove their belonging. A scene in a fashion salon was the central scene in Die Nacht von Berlin. Produced in 1911 ,

${ }^{101}$ Landesarchiv Berlin, Metropol Theater, 18.10.1909, Hallo!! Die grosse Revue, Rep. 30 c/a Theater Z, Neuer Teil 4559. For original see Appendix 14, pages 302-303. 
and scripted yet again by Julius Freund to the music of Victor Hollaender, this was one of the last Metropol revues to appear on stage.

Fashion had been a central theme of most Metropol productions. However, whereas it was presented for its own sake in the opening night of the Metropol in 1898, it gained a politicized meaning in $1911 .^{102}$ Whereas in 1898 the critical Berliner Börsen-Courier pitied Julius Freund for ranking second to the art designer in the theater's hierarchy, by 1911 the balance had shifted in favor of the script-writer. ${ }^{103}$ The great importance of fashion in a society in search of social distinctions was the main theme in Die Nacht von Berlin. The almost religious belief of some of Berlin's Jews in the elevating powers of French fashion is satirized in the following scene. Like the sun king, the designer Poiret enters the scene with pomp and glory, humbly greeted by an assembly of women and their devoted husbands. A Jewish couple is among those who can hardly await his appearance. Mister Cohn and his ugly, overweight wife eagerly anticipate Poiret's entrée, hoping that the "healing" powers of the fashion God will "cure" Mrs. Cohn's malaise. They quickly reveal themselves to be first-generation Jewish immigrants from Poland who have "made it" in Germany. They lack manners and the

${ }^{102}$ In hisproduction-number spectacular, Berlin bleibt Berlin, Richard Schultz declared his close ties to Berlin's fashion industry by explicitly promoting their products on stage, going as far as having actors and dancers display the logos of well-known department stores on sets and costumes. The press unanimously rejected such unusual advertisement campaigns, and pointed to the indignation of the hissing and whistling audiences. Despite the unanimous condemnation of such blatant advertisements on stage, however, the overall reception of Berlin bleibt Berlin was sufficiently positive to guarantee this production an outstanding financial success. Visitors, although skeptical of commercialization, were nevertheless interested in the display of fashionable costumes. Schultz and his collaborators, in turn, moderated their explicit advertisement slightly in the following revues, without, however, giving it up altogether.

103 "It must be devastating for a talented script writer such as Julius Freund to be interrupted by decor designers, and having to avoid everything that could potentially overshadow the 
appropriate reserve: the essence of elegance and refinement. They are not the only ones, however, without the necessary inside knowledge of French haute couture. Mr. and Mrs. Lehmann, two "Berliner originals" are equally unprepared for the rituals unfolding in front of them, although their obviousness has a different ring than the Cohn's ignorance. They represent the voice of the people, bewildered by Poiret's French decadence, grounded in their matter-of-factness, they were intended to provide a refreshing contrast to the general exaltation. To appreciate this scene fully, one has to be aware that the fashion designer Paul Poiret actually existed and was not a figure born of Julius Freund's imagination. In 1911 - the year of this revue was staged-- Poiret gained fame for being the first designer to successfully promote the so-called reform clothes (Reformkleidung) for women. Together with the fashion houses Hermann Gerson and V. Mannheimer -- both established Jewish clothing manufacturers in Berlin - he caused a sensation by displaying his models without the usual straps, buckles and corsets at one of the big fashion shows of the season. This was a daring move in a society that only recently had arrested prominent German feminists for wearing reform clothes, then perceived as a provocation and offensive to the German public. ${ }^{104}$

By some contemporaries Poiret was seen as a great liberator of Wilhelmine women; in the eyes of others, however, he epitomized a corrupting influence on the female mind. For some he signified modernity and progress, for others he was an apostle of foreign influence in Imperial society, and Julius Freund integrated all these conflicting dimensions into his play, Scene 4 of this play:

The Directrice (excited, followed by the audience)

"Eleven o'clock - the great moment has come! I am feverish from excitement - Ladies and Gentlemen - please be seated; the middle isle has to stay empty.

technicians." Brandenburgisches Landeshauptarchiv, 30 Berlin C, Tit. 74, Th. 714, Akt. 18, Berliner Börsen-Courier, September 4, 1898.

${ }^{104}$ Uwe Westphal, Berliner Konfektion und Mode. 1836-1939. Die Zerstörung einer Tradition (Berlin, 1992), 39-40. 
TheMaster: Eleven o'clock! He has arrived! He has arrived! (To the Directrice) I hope you have made sure that all the entrances are blocked and only the most intimate customers of the house are led in after showing their tickets.

Directrice: Certainly!

Mr. Cohn to his wife: Rosalie - relax! Don't get so excited! He will look at you; he will take your measurements - but after all - he is no magician!

The Master:

Silence! Silence, Ladies and Gentlemen! The historic moment has arrived! (a stroke of the gong). The gong has sounded!

Mr. Cohn: Heisst e Gegonkel wegen dem Onkel!

(mannequins wiggle down the stairs and through the curtains, accompanied by music. They make their rounds and everybody stares at them [begafft und longnettiert].)

The teenager: What beautiful girls.

Mr. Cohn: Besicheinte Schickses! Look just how they wiggle.

Mrs. Cohn: Look away Isidor!

The Master: These are the mannequins.

Mr. Lehmann:Wat heest Manekens? Ik hab det für Weiberkens gehalten!

(The gong sounds twice)

The Chef: Silence! Silence! Ambiance! Ambiance! Fast, fast the censer! The curtain is rising! Now! Now!

(The curtain parts accompanied by ceremonial singing, while the mannequins are waving the censers. On a throne, surrounded by kneeling clothing manufacturers, Poiret presides, while ladies are holding a golden laurel wreath above his head.) ${ }^{105}$

This scene does not ridicule just any fashion frenzy, but rather the continuing reverence of French haute couture specifically. La Grande Nation is parodied in order to reclaim these virtues for Berlin. It is not fashion as a concept that is at stake in this scene, but the uncritical reverence of French fashion by Germany's parvenus in search of taste and respectability. Although Mr. and Mrs. Cohn were wealthy enough to pay the outrageous sums Poiret prides himself that he can charge his German clients, they were not secure enough in their own judgment to develop style and countenance by themselves. The Cohns try to cover their humble

${ }^{105}$ Landesarchiv Berlin, Die Nacht von Berlin, Metropol Theater, Rep. 30 c/a, Theater Z, 
origins with the graceful disguise of French haute couture. Their sensibilities do not conform to those of their environment, however, and their reading of the situation isolates them from the other characters as well as from the audience. Unknowingly they are the objects of ridicule and laughter, since they lack the sophistication to match their wealth.

In his depiction of Poiret and his art, Julius Freund mocked the simple look of reform clothes, a look that so excited the fashion-conscious circles of Berlin's society. The scene thus continued with a demonstration of Poiret's talents. Mrs. Cohn's rather imposing exterior presented his greatest challenge. Her transformation thus served as the ultimate proof of his ingenuity. In liberating Mrs. Cohn of all her superfluous clothes, Poiret demonstrated to the Metropol audiences how, in the realm of fashion, less could be more. Despite the satirical tone of this scene, Mrs. Cohn did look slimmer and more pleasing to the spectators after Poiret had unwrapped her. Poiret succeeded in his venture and made Mrs. Cohn's dreams come true, leaving Mr. and Mrs. Cohn overjoyed. The latter did not realize that the means for such transformation were quite basic. Instead of exquisite accessories, Poiret used any utensil that came into his hands, such as a wastepaper basket for a hat and a random cord to gather up the loose cloth:

Poiret: You will see now, how Poiret, the genius can transform en cinq minute la femme la plus laide - the ugliest woman -- la femme la plus terrible -- the most horrific woman -- (Looks around)

Mr. Cohn: Rosalie -- Volunteer!

Poiret (grabs Mrs. Cohn and pulls her towards him) Madame!

Mrs. Cohn: Quel bonheur!

Poiret: Ce costume! Quel blamage! Quel desastre! Desagreable! Away with it! Away! Away! Away!

(Tears away down the dress made out of paper and leaves her standing in her funny undergarments)

Mr. Cohn: Poiret! Why do you make my misfortune public!

Poiret: Silence! Silence! Do not disturb my inspiration!

Neuer Teil, 5140. For original see Appendix 15, pages 303-304. 
Ah! La portiere! (Runs for the curtain. Pulls it down and ties it around Mrs. Cohn, whose costume is designed so that after she looks slimmer than before..

Amandine - les Cheveux (an assistant passes him a high wig, which he puts on her (un chapeau! Un chapeau! Ah - Voila -

(takes a small paper basket)

Superb, ravissement! Mais la corde, la corde! Where is the cord, the cord?

$[\ldots]$

All: Bravo!

Mr. Cohn: Rosalie- You look like the crown princess of Posnan!

Poiret: And in one week from now, when the revue is over -- I will return to Paris! $!^{106}$

In the this scene, the script writer Freund reproduced well known prejudices which were particularly wide-spread among upper-class Berliners who were eager to solidify their monopoly on culture and refinement. The Cohns exemplify those segments of society for whom fashion was an entry ticket into bourgeois society. Insecure in their own judgment, they become the devotees of a charlatan. The spectator was meant to feel superior to these two characters who struggled to make a life for themselves in an unfamiliar social milieu. Julius Freund -- in contrast to his previous handling of a similar scenario -- this time caste his Jewish characters adrift, leaving them open to the scorn of the audience.

In 1911, international comparisons are treated differently than in previous years. Caught in a wave of increasingly nationalistic rhetoric, the continuing fascination of Berliners with French fashion and design is now criticized more than ever. Berlin's fashion industry, which was one of the most important local industries, had begun to promote its own collections, by deliberately competing with Paris. ${ }^{107}$ Instead of celebrating Berlin's equal status

${ }^{106}$ Landesarchiv Berlin, Die Nacht von Berlin, Metropol Theater, Rep. $30 \mathrm{c} / \mathrm{a}$, Theater Z, Neuer Teil, 5140. For original see Appendix 16, pages 304-305.

${ }^{107}$ In 1914, only three years after the revue Berlin bleibt Berlin, the presence of French fashion was even violently attacked by the press. „In the first days of August 1914, the newspapers began to complain about the inappropriate clothes of our women, promenading in skirts with slits and high heals, while their husbands and brothers defended our soil with their 
to London or Paris, the Metropol now celebrated Berlin's superiority over French couture. Freund flattered the spectator's ego by pointing out that although Poiret triumphantly celebrated French hegemony in the realm of fashion, he envied Germany's energy and prosperity [with a heavy French accent]:

En revenant de la revue

I will return then to Paris

From my grande gloire sein plein

'Figaro', 'Temps', 'Journal', 'Matin'

The pockets full with German money,

Both a tailor and a hero,

I will tell on the boulevard -

How I worked for our revenge!

In the year one and seventy,

In the shine of glory,

Germany has had its chance,

Has got millions from la France,

But if from dawn to dust,

My business continues like this,

Then I will soon return

All of the reparations!

No Boulanger

And neither Delcassé

Have fooled Germany as much

only Poiret emptied its portemonaie!

C'est la revanche

De la nation française $e^{108}$

blood at the front lines." Sandra Clara, Die Mode im Spiegel des Krieges (Essen and Cologne, 1915), 4, quoted in Westphal, Berliner Konfektion, 45.

${ }^{108}$ Landesarchiv Berlin, Metropol Theater, Die Nacht von Berlin, Rep. 30 c/a Theater Z, Neuer Teil, 5140. For original see Appendix 17, page 306. 
Julius Freund was aware that after the lost war of 1870-71, France had undergone a trauma that still resonated in the French consciousness. French travel accounts reveal that although Berlin was dismissed as a sleepy garrison town before unification, by the turn of the century its boom-town qualities were either admired, feared or dismissed by French contemporaries. ${ }^{109}$ Berliners enjoyed such new attention and respect, satisfied that their own long-standing admiration for Paris at last being reciprocated (however grudgingly).

Fashion functioned as the expression and the vehicle of social advancement and distinction in Metropol revues, simultaneously satisfying the individuals need to blend in with the majority and yet to find an expression for individuality. ${ }^{10}$ Although fashion promised to be a vehicle for temporary empowerment and equality -- a message the Metropol revues emphatically celebrated by boasting the slogan: "clothes make the person" (Kleider machen Leute) -- Jews were often ridiculed for their ill-conceived attempts to use fashion as a tool for social advancement." "Whereas a focus on the fashion industry fostered local and national pride, allowing Berliners to celebrate their achievements and competitiveness with Paris or London, the Metropol theater ridiculed Jewish entrepreneurs in Berlin's fashion industry.

${ }^{109}$ Cecile Chombard-Gaudin, "Frankreich blickt auf Berlin 1900-1939," in Gerhard Brunn and Jürgen Reulecke, eds., Metropolis Berlin. Berlin als deutsche Hauptstadt im Vergleich europäischer Hauptstädte 1871-1939 (Bonn, 1992), 367.

110 "Classes and individuals who demand constant change, because the rapidity of their development gives them the advantage over others, find in fashion something that keeps pace with their own soul-movement. Social advancement above all is favorable to the rapid change of fashion, for its capacitates lower classes so much for imitation of upper ones, and thus the process characterized above, according to which every higher set throws aside a fashion the moment a lower set adopts it, has acquired a breadth and activity never dreamed of before." Simmel, op. cit., 318.

111 Originally "Leute machen Kleider - Kleider machen Leute", this expression gained great popularity through Gottfried Keller's novel "Kleider machen Leute," a humorous allegory on the doubled standards of middle-class morality, published in 1874 as part of the cycle: "Die Leute von Seldwyla." 
Although Jewish manufacturers helped to bring Berlin's fashion industry to unknown heights of world class and fame, Jewish characters on stage often lacked the finishing touch of la haute couture. Unlike the Hermfeld theater, the Metropol theater singled out its Jewish characters as individuals apart, who, however, belonged to the daily life of the capital. Traditional Jewish stereotypes circulating among Berlin's high society were reproduced, linking Jews to both the vices and virtues of modern urban life. In Paradies der Frauen (1898), the Jewish character (yet another schöner Isidor) was a Confektions-Commis who courted a fashion-crazed diva. In the revue Berlin bei Nacht, the Jewish characters (the Cohns) were ridiculed as unwitting consumers of haute couture. ${ }^{112}$

The Metropol theater and its revues faithfully mirrored the aspirations and prejudices of upper-class Berliners. Depending on current political events its Jewish characters were painted in a more or less positive light, sometimes sarcastic and sometimes affectionate. There are consistent patterns in the Metropol's depiction of Jews. For example, most Jewish characters quickly reveal their Eastern European origins in the course of a scene. The established Jewish community of Berlin was rarely ridiculed on stage, but rather recent Jewish immigrants who could not shed their roots in Berlin's "Jewish milieu." Staying true to Gentile upper-class humor, the "little Mister Cohn" was the "ideal-type Jew" at the Metropol theater. ${ }^{113}$ The Jewish

112 Even the openly antisemitic paper the Staatsbürger Zeitung approved Guido Thielscher's endearing performance as the "schöne Isidor" : "The irresistibly funny Guido Thielscher conquered the hearts of Berliners as the "beautiful Isidor," the revered KonfektionsCommis. His amicable, fun-loving humor provoked a more and more cheerful atmosphere in the auditorium with every minute." Brandenburgisches Landeshauptarchiv, 30 Berlin C, Tit. 74, Th. 714, Akt. 19, Staatsbürger Zeitung, September 7, 1898.

${ }^{113}$ The Metropol theater made the popular song "Der kleine Herr Cohn" a staple at one of its balls. As a reporter laconically remarked, while describing his evening at the Metropol: "One last glance over Berlin's camival, before, being a solid man, I leave the site. Through the dense cigar smoke resounds the song of the little Mister Cohn," Brandenburgisches Landeshauptarchiv, 30 Berlin C, Tit. 74, Th. 708, Akt. 214, Berliner Börsen Zeitung, January 12, 1904. 
stockbroker who talks with his hands; the businessman who fails to say the truth, even when he tries; the Jewish mother who dreams of beauty and cultivation: all of these types were drawn from upper-class discourse and were integral part of the Metropol repertoire. The Metropol's message remained ambiguous and at times even contradictory. Although it touted the superiority of Berlin's garment industry, it ridiculed the Confections Commis Isidor. Although the famous Ausstattungshaus Baruch provided the outlandish costumes and magnificent robes of all actors at the Metropol theater, and the department stores Wertheim, Jandorf and Tietz made exclusive fashion available for a wider audience, Jewish clothing manufacturers were subjected to ridicule.

These depictions of Jewish characters, in short, were unflattering and at times vulgar, but they were hardly meant to stir up racial hatred. They were part of the metropolitan mosaic, and as such thought to be indispensable. These jokes did not allow the spectator to forget that a special relationship existed between the Jews being caricatured and their Gentile environment.

Choosing Guido Thielscher to play most of the Jewish roles at the Metropol, was a clear indication that these roles were not meant to be despicable. Thielscher was one of the most acclaimed comical actor in Berlin, adored by Berliners as few actors before him. He was one of the few Metropol stars who was not imported from Vienna hence, he brought identifiable local flair to the stage. In the role of the schöne Isidor Thielscher demonstrated a naive enthusiasm for Berlin, exclaiming on the Metropol's opening night in 1898 that "the slogan was neither north nor south pole, but Metropole."114 Thielscher's adaptation of a Jewish character did not allow the spectator to distance himself, instead Thielscher provided an opportunity for Berlin's high society to take a vacation from their complex lives, leaving the merits and constraints of the juste milieu behind. He functioned rather like the classic dramatic

${ }^{114}$ Brandenburgisches Landeshauptarchiv, 30 Berlin C, Tit. 74, Th. 714, Akt. 17, Das kleine Journal, September 4, 1898. 
fool: he flattered audiences while he regularly exposed himself and others to ridicule and laughter.

Although Julius Freund's jokes and verses were often mere reproductions of contemporary Herrenwitze circulating in Berlin's casinos, he did try to break the pattern, whenever it seemed opportune. When the pairing of rivals was part of governmental policy, Julius Freund appealed to his audience to exercise tolerance toward the other. In the revue Das muss man sehn!, the Metropol tried to defuse social and cultural antagonisms in Wilhelmine Germany's social fabric, by advocating the relativity of political opinions and the transparency of social boundaries. The Metropol revue did not, however, legitimate difference or embrace a plurality of ethnic groups. Social conflicts were not meant to be negotiated on stage, but temporarily laughed away.

The rise in nationalistic rhetoric on stage shortly before the outbreak of the war led to an ever cruder portrayal of Berlin's Jews on various stages. Both the Metropol theater and the Metropol cabaret, two independent enterprises aiming for similar audiences, presented an increasingly negative image of Berlin's Jews. Hence the strategy of using the Hermfelds as stage characters became transparent. Whereas in 1907 Rosalie Hermfeld was an amicable figure, by 1911 the brothers Herrnfeld had become the incarnation of new money paired with bad taste. In the same year that Die Nacht von Berlin was staged at the Metropol theater, the Metropol Cabaret presented a sketch that, according to police reports, imitated a number of Berlin's "most well-known performers." 15 The Herrnfelds were among those caricatured. Their characters were introduced with the following line: "Anton und Donat Hermfeld, Natürlich an allen zwölf Fingern Brillianten, im Kragen Brillianten, im Haar Brilliantine, überall Brillianten." 116 Spoken by Martin Kettner, a comedian who also worked at the Metropol, these lines had been written in collaboration with Rudolf Nelson, the director of the

${ }^{115}$ Brandenburgisches Landeshauptarchiv, 30 Berlin C, Tit. 74, Th. 718, Akt. 15.

${ }^{116}$ Brandenburgisches Landeshauptarchiv, 30 Berlin C, Tit. 74, Th. 718, Akt. 15. 
Metropol Cabaret. The brothers Hermfeld felt insulted by this depiction and complained to Berlin's police. They were obviously sensitive to the implications made by these introductory lines and felt confident enough to press for charges against a competitor. Berlin's police, however, could see nothing insulting, and did not censor Kettner's performance in any way. ${ }^{117}$ Jewish librettists such as Julius Freund, Fritz Grünbaum and Rudolf Nelson invented the Jewish characters, positive or negative who peopled Berlin's revue stages. Jewish writers scripted the verses that Jewish comedians delivered and Jewish musicians played. The fact that these depictions were not always flattering did not cause discomfort among most German Jews in the first decade of the twentieth century. That Witzkultur of Imperial Germany accommodated such depictions of Jews on stage and there is no indication in the pre-war period that Jewish artists resented these jokes and verses. During the war, however, German Jews suddenly began to fear identification with such "Cohn- characters." In 1915, for example, Berlin's middle-class Jewish community criticized Rudolf Nelson for indecent and denigrating Jewish jokes on stage. In an anonymous letter to Berlin's police authorities, a Jewish woman asked whether it was appropriate, that "at a time when hundreds of Jewish soldiers are earning the Iron Cross, is fitting that filthy Jewish tales [Jüdische Unflätigkeiten] are told - unfortunately by a person who himself is Jewish? Words like tineff, chuzpe, ponim, as well as repulsive Jewish jokes may well please the well-dressed Jewish Kurfürstendamm plebeians, but are severe insults for decent Jewish women who have husbands on the field of battle." 118 As this complaint reveals, by 1915 the Yiddish language carried a stigma in German society that was offensive to the sensitized ears of Berlin's established Jewish community. At a time when Jargon theaters struggled to survive, even such relatively high-class entertainment as the Metropol theater and cabaret experienced a setback in public approval. The tolerance for "Jewish humor" fell off precipitously among the Jewish audience during the war and its

${ }^{117}$ Brandenburgisches Landeshauptarchiv, 30 Berlin C, Tit. 74, Th 718, Akt. 15. 
immediate aftermath. Jewish artists reacted to this change in climate slowly. A key reason -although not the only one - was that antisemitism did not play anywhere near as large a role in their sheltered lives as members of Berlin's entertainment scene as it did in the lives of most other Jews in Germany.

${ }^{118}$ Brandenburgisches Landeshauptarchiv, 30 Berlin C, Tit. 74, Th.1514, Akt. 1-3, anonymus letter is dated January 15, 1915; quoted by Jelavich, Berlin Cabaret, 123-124. 


\section{Conclusion}

The Metropol theater was instrumental in the formation of a new elite in Imperial Berlin. By the turn of the century, that elite included the upper echelons of Berlin's Jewish community. To define their own identities these elites turned to popular entertainment such as revue theater. The celebration of the big city at the Metropol theater allowed Berlin's new elite to read itself in a rapidly changing environment. By stylizing the urban experience in Berlin, Richard Schultz helped to create an image for his affluent audiences. The Metropol helped these new elites to consciously define their boundaries. To integrate a wide social spectrum of spectators, the Metropol revue did not provoke or polarize its audiences . More typically it played upon common denominators such as wealth and class among its upper-class audiences. By idealizing and celebrating the capital and its new elites, the Metropol theater bridged potential political or ethnic gulfs among its spectators. Religious and political antagonisms were more typically papered over than uncovered and explored.

By focusing on Berlin -- its politics, fashion, and societal scandals -- the Metropol revue reflected particularly on Gentile-Jewish relations in the city. Jewish characters were commonplace in the pre-war Metropol Jahresrevue. Depending on Germany's social and political climate, its highly stylized Jewish characters were depicted as either endearing or ridiculous. One of the most striking features of the Jewish roles presented at the Metropol was their assumed eastern-European origins. The established Jewish community of Berlin was not primarily ridiculed on stage, but Berlin's "Jewish milieu," epitomized by the "little Mister Cohn."

Although one cannot imagine the genre of pre-war revue theater without its outstanding Jewish performers, librettists, and composers, these artists did not develop a visible collective identity. Unlike those Jews involved in circus enterprises or Jargon theaters, Jewish artists in Berlin's revue theater in Berlin were not characterized by their ethnic solidarity. Whereas 
Jargon theater performers and circus artists still felt part of a collective, Jewish entertainers at the Metropol theater did not. Highly assimilated, Jewish performers engaged at the Metropol hardly ever impersonated Jewish characters. It was significant that the Gentile actor Guido Thielscher specialized in such roles.

But Jewish artists were involved in the creation of Jewish characters . Jewish librettists such as Julius Freund, Fritz Grünbaum, or Rudolf Nelson invented the numerous Jewish characters on the stages of Berlin's entertainment scene. Jewish writers scripted the verses that were accompanied by Jewish musicians. The fact that these depictions were not always flattering did not cause discomfort among the Jews in the Metropol audiences. The Witzkultur of upper-class Berlin accommodated such depictions of Jews on stage, and there is no indication in the pre-war period that these jokes and verses were resented. Facing a marked rise in antisemitic rhetoric in the general public after 1916, however, the tolerance for ,Jewish humor" faded markedly among Jewish audiences. Due to their sheltered lives in the entertainment scene, Jewish artists reacted slowly to this change in climate. Although they were not completely oblivious to social tensions, Jewish artists hoped to deflect them by further stressing the distinction between the assimilated Jewish community in Germany and Jews from eastern Europe. Berlin's established Jewish community, in turn, felt increasingly uneasy about such depictions of Jewish characters on stage, because they feared the negative consequences of being publicly associated with the image of Ostjuden.

With the decline of the Jahresrevue, Jewish characters ceased to be a commonplace of revue entertainment. In the post-war period the Metropol, focusing on operetta entertainment instead, escaped into a dream world of the past. Jewish identity and relations between Jews and Gentiles did not figure prominently in the post-war revues and operettas, at least partly because modern Berlin was no longer the site of local pride and nightly excitement on stage. The question of Jewish integration and the rise of antisemitism did, however, play an increasing role in the perception of the Metropol as a cultural institution. Bought by the theater entrepreneurs Alfred and Fritz Rotter, it became part of one of the largest theater trusts in the 
history of live entertainment in Berlin. The financial scandal around the Rotter brothers shifted the Metropol to the center of a vicious debate about alleged "Jewish dominance" in German live entertainment. By the late 1920s, the active role Jews had played in many areas of German popular entertainment had almost come to an end. 


\section{Conclusion}

Exploring circuses, Jargon and revue theaters -- their origins, their performers, their audiences, and their aesthetics - has led us to appreciate the variety of Jewish identities in German entertainment. This great variety reflects the many ways Jews chose to engage in popular entertainment. As has been shown, Jews were an integral part of the growing entertainment industry. The meritocratic nature of popular entertainment and the noticeable absence of ethnic discrimination made this sphere particularly attractive for potentially marginalized groups such as German Jews, and was conceived of as an opening into German society at large. Jews were involved as actors, directors, consumers, sponsors, managers and agents. Many also worked in the supporting industries, such as garment making, and publishing. With the remarkable growth of the entertainment industry, distinct genres emerged. To be sure, these genres operated in different ways, but Jewish artists adapted to the inner dynamic of each one to find their own distinctive voice. Although distinctions have to be made between various genres of popular entertainment, this study has argued that popular entertainment challenged current social distinctions and restrictions at work in other public spheres. Popular entertainment offered an arena for the relatively unrestricted interaction among various social groups. In this arena, as in few others, Jewish actors and acrobats had the opportunity to display and communicate their ethnic identities. What might otherwise be perceived as alien appeared exotic and intriguing on stage; in this sense the stage served as a mediator between Jewish artists and other Germans.

An acceptance of the distinctiveness of Jewish artists on stage does not allow for the conclusion that they enjoyed complete integration into German society at large. As studies such as Marion Kaplan's have demonstrated, one has to pay scrupulous attention to the context of interaction when examining the question of Jewish integration and identities in modern German society. German Jews were known to invoke their Jewishness in different ways depending on 
their social environment.' Similarly, whether Gentile neighbors, colleagues, superiors or employees were more or less welcoming to Jews depended on the setting. Although their ethnic background may not have disadvantaged Jews in many professional situations, they were often not welcome to join a private club or semi-public association. Having found little evidence of discrimination in the entertainment industry does not permit us to conclude that Jewish entertainers enjoyed unquestioned acceptance and integration into German society at large. The difficulties they encounter, however, were not necessarily only provoked by their distinct ethnic identity. Especially in the pre-war period it is difficult to distinguish whether Jewish performers in popular entertainment encountered discrimination outside the realm of popular entertainment because they were Jewish artists or because they were popular artists. Although Jewish artists profited from the opportunities that popular entertainment offered, they simultaneously suffered from the limitations they faced as popular artists.

Depending on a number of factors, ethnic identities in circuses, Jargon and revue theaters manifested themselves in various ways. The artists' degree of assimilation into society was certainly the most important of these factors. The social profile of these artists -- their language and family ethos -- influenced their self-perception and the way they related to their audiences. For example, whereas Jewish circus families conversed in a jargon that defined them as a group, Jewish revue artists spoke High German, which did not carry a specific ethnic marker. In addition, Jewish entertainers enjoyed different degrees of artistic freedom depending on whether they owned their entertainment enterprises or whether they were simply part of the staff in a predominantly Gentile business. Circuses and Jargon theaters run by Jewish families could choose independently what they wanted to communicate to their audiences. Jewish artists in revue theaters, by contrast, were part of a team; hence they had to harmonize their individual agenda with management and other staff members. Lastly, the social composition of each

${ }^{1}$ Marion Kaplan, The Making of the Jewish Middle Class. Women, Family, and Identity in Imperial Germany (New York, 1991). 
genre's audience was crucial in shaping the dialogue between Jewish performers and spectators. Mass audiences that included all segments of society had different expectations than elite audiences; and their reactions to popular performances were equally distinct.

Jewish artists in popular entertainment harbored a specific concept of belonging, as members of a nation, a milieu, and a family. Jewish circus families, for example, tried to create a world that responded to their needs and dreams, in which they could transcend former discrimination to move freely and unrestrictedly. In the pre-war period, the circus provided a realm of unique social and aesthetic possibilities that seemed to facilitate this transcendence. Jewish circus families embraced the social order and the moral ethos of Imperial society. Their conservatism was not least reflected in their traditional aesthetics. However, Jewish circus performers did not accept the shortcomings of Jewish emancipation in Germany and the continuing discrimination against Jews in public life. Within their own "circus empire" they staged what they thought was an ideal world of humanity, governed by self-respect, honor, and chivalry. Although they tried to preserve that ideal world, it ceased to correspond to the needs and desires of their social environment by 1916 (at the latest).

Whereas circuses chose to present an idealized version of the German Empire without offering Jewish entertainment per se, Jargon theaters, by comparison, directly mocked and addressed the issues of Jewish assimilation and integration on stage. Both circuses and Jargon theaters identified core values of Imperial society, on the basis of which they established an intimate rapport with their specific audiences. Yet whereas circuses alluded to heroism, authority and beauty -- overarching values that appealed to all segments of society -- Jargon theaters identified the middle-class family ethos as the greatest common denominator with their audiences. On stage, performers reaffirmed their Jewishness within the intimate setting of family life. The daily quarrels in Jewish families were the prime focus of Jargon theater plays, and their universal quality made them attractive for an audience of Gentiles and Jews. In this setting, Jargon theater addressed the trials and tribulations of Jewish emancipation in Imperial Germany. Mixed marriages, Jewish religious customs, Jewish self-hate and antisemitism were 
themes Jargon theaters raised consistently. While amusing their Gentile audiences with family farces, Jargon theater assured their Jewish audiences that they were not alone in dealing with such difficulties. Jewish humor in pre-war Jargon theater provided comic relief by confronting issues that members of the mixed audiences did not commonly address in public.

Pre-war revue theater operated differently from both circuses and Jargon theaters. Revue theater was directed at the most affluent segments of society. To appeal to its elite audience, it presented exclusivity, elegance, and modernity as its central themes. Although Jewish artists were involved in the production of revues, they were employees, not managers or directors, in the enterprise. The portrayal of Jewish characters -- a commonplace in pre-war revues - was as much the product of the Jewish librettist's imagination as it was a reflection of the target audience. Because one of the main themes of revue theater catered on the task of determining who was part of the in-crowd and who was not, Jewish characters on stage often functioned as the necessary outsider, whose presence helped to establish the insider. Each of theses roles had an identifiable metropolitan dimension. Berlin's elites tended to defined themselves vis-à-vis the metropolis. To avoid alienating upper-class Jews among the audience who were part of Berlin's new elite, Jewish characters were often portrayed as recent immigrants who still lacked the refinement and composure of their better established fellow Jews. Unlike circuses and Jargon theater, which did not seek to replicate the insider-outsider dichotomy on stage, the revue theater did exactly that, by overlaying issues familiar to all Berliners with thorny questions of ethnicity and class.

For all three genres, the First World War constituted a great watershed in their aesthetics. The collective trauma of total war not only affected the economic and social wellbeing of all segments of the German population, but it fundamentally changed the tastes and sensibilities of the spectatorship. Violent death became a haunting reality: it was present in everyday life, and it irreversibly transformed the inner lives of the audiences. In circus performances, death became the leitmotif of the now popular Todesartistik, displacing earlier themes such as romance, chivalry, exclusivity and eroticism. Traditional horse shows, a staple 
of the shows of Jewish circus families, found diminishing resonance. Formally, these acts had endorsed a pseudo-military honor code and recreated memories of noble chivalry. After the advent of total war, they suddenly appeared anachronistic and inadequate. In the aftermath of the war, very few Jewish enterprises managed to adjust to the changed expectations of their audiences. Even those that did so initially, collapsed due to violent racial antisemitism in the late 1920s.

Jargon theaters declined in popularity even more steeply than did circuses run by Jewish families. As a predominantly Jewish genre of entertainment, they were hit hardest by the change in the political climate during and after the First World War. Their agenda, presenting a world in which a diversity of social groups could live in harmony, did not appeal to an audience that had become only too aware of the dividing lines that separated different worldviews, milieus, and classes in post-war Germany. Jewish audiences in particular had become disillusioned with the course of Jewish emancipation and assimilation in Central Europe. Jewish jokes became intolerable for a Jewish community that increasingly felt under siege. In an effort to survive, Jargon theaters were required to change the style, content, and humor of their performances. In the process they ceased to be popular Jewish theaters at all. Sex and death became the common denominators in the early years of Weimar Germany's entertainment. A division of labor became apparent: circuses began to specialize in death; variety theaters, including the former Jargon theaters, focused on sex.

Whereas circuses and variety shows addressed the nightmares of total war, revue theaters helped to suppress them. While in the pre-war era revues had focused on what Berlin's imagined future would bring to the rich and famous, saccharine operetta entertainment in the post-war period reflected on the lost glory of an (equally imagined) past. Jewish characters did not figure prominently in the latter, because modern Berlin was no longer the site of the same local pride. Jewish characters who fit comfortably within metropolitan mosaic in the pre-war revue had no place in the realm of mythical, allegorical formulae preferred by the scriptwriters, directors and audiences after 1918. Instead the Metropol theater, as one of many theaters 
owned by the Rotter brothers, became a focus of antisemitic propaganda in the late 1920s. Its Jewish owners became the target of vicious polemics against a "Jewish brand of capitalism“ that was conveniently blamed for the larger crisis in Berlin's theater scene in the late 1920s. This defamatory campaign against the Rotters demonstrated just how highly visible Jews had become scapegoats for the general malaise in German society.

The First World War can hardly be overemphasized as an event that prompted a paradigmatic shift in Jewish identities within German popular entertainment. That the war proved equally convulsive in the social, economic and political realm should not distract us from this important shift in the cultural sphere. Before 1914, Jewish performers, librettists and acrobats had established a realm in which they could suspend or overcome discrimination based exclusively on ethnic difference. The war brought politics and culture into such close proximity that this suspension was threatened or ceased to exist. When the added factors of economic hardship and the humiliation of defeat brought social tensions and antagonisms to the fore, the brutalization qua politicization of popular entertainment disrupted a dialogue between Jewish performers and their audiences. Far from being in the forefront of modernizing trends within society, Jewish artists did not respond flexibly to these challenges. They were reluctant to give up aesthetic forms and lifestyles that had proved to be successful for so long, and many of them felt wholly overwhelmed by the avalanche of events. 


\section{Appendix}

\section{Appendix 1:}

Das Herrnfeld Theater

Ihnen gesagt, auch e' Theater;

'ne Schmiere mitten in Berlin!

Zwei jüdisch-daitsche Klassiker,

Die importiert sind über Wien,

Sind Pächter dort und Direktoren,

Sie spielen täglich selber sich,

Zwei Jüden sind's vom reinsten Wasser

Und leider keine Juden nich.

Sie schreiben sich die Stücke selber,

Zwar sagt man, Schammes hilft dabei,

$\mathrm{Na}$, wo drei solche Köche kochen,

Wird ungenießbar jeder Brei.

Man kann die besten Stoffe stehlen,

Hat man zum Schreiben kein Geschick,

Und dreie fanger: an zu flicken,

Verhunzen sie ein jedes Stück.

Und finden sich genügend dumme,

Den Jüdenschmarrn sich anzuseh'n,

Und edle deutsche Preßorgane,

Die um Annoncen betteln geh'n

Und diese Schweinchen=Direktoren, 
Für ihre Inserate Ioben;

"Nu, Kunstück, Hermfelds zahlen bar!"

Das Publikum, so blöd' wie immer,

Fällt auf den faulen Zauber 'rein

Und freut sich diebisch, wenn auf Juden

Die Jüden schimpfen hundsgemein;

Wenn man den Juden macht zum Schurken,

Der sich vom falschen Eide nährt,

Und jeder Christ sich sagt behaglich:

"Ihr Juden seid einander wert!"

Doch ist solch' Herrnfeld gar kein Jude,

Jüd ist er, wie er leibt und spielt,

Der Jüd, der größten Feind des Juden,

Der dessen Ehre unterwühlt.

Und dennoch geh'n selbst Israeliten

In diesen Tempel daitscher Kunst,

Um dort zu sehen, wie die Juden

Dies Dichterfürsten=Paar verhunzt.

Wenn diese Inserat=Artisten

In Wichse machten, in Opal,

In alten Hosen oder Möbeln,

So wäre dieses höchst egal,

Doch an der eig'nen Rasse treiben

Prostitution für schnödes Geld 
Mit Hilfe feiler Preßorgane,

Was nied'ren Kreisen zwar gefällt,

Das müßte doch die meisten ekeln,

Sei man nun Jude oder Christ; ---

-- Doch jeder geht in das Theater,

Das seines Geistes würdig ist!"2

\section{Appendix 2:}

Rüdersberg:

[... ] ...weißt du denn, welche Motive sie dazu verleitet haben?

Knolle:

Ich hab se nicht dazu veranlaßt!

Rüdersberg:

Das glaube ich, aber sieh mal [sich drehend] das glänzende Elend hier im Hause -- junges Blut, -- Genußsucht, Umgang mit Anderen, die vielleicht ein bisschen mehr haben - gute

Freundinnen -- hier ein Volant am Rock, seidene Unterröcke, dort ein Spitzenchen mehr -tambourierte Strümpfchen, ja wir können uns da gar nicht reindenken, das ist eben unsere sociale Frage -- der Reiz des Lebens, jedes Fabrikmädchen -- hat den Wunsch einmal sich zu fühlen...

Knolle:

Aber det Mädchen hat doch nischt, se hat doch nischt!

Rüdersberg:

Weisst du Gottlieb, du hättest sie doch wenigsten fragen sollen, warum sie es getan ...."3

2 A.D. Weber, Berlin und die Berliner (Berlin, n.d.), 44-46.

${ }^{3}$ Landesarchiv Berlin, Nachtdienst, Schauspiel aus dem Berliner Leben, Gebrüder Herrnfeld Theater, Rep. 30c/a, Theater Z, Neuer Teil 2320. 


\section{Appendix 3:}

Knolle:

Willst du mir nu sagen, wat dir bewogen hat/da steht se nun - de Olle mit det verstockte Gesicht! Ich hätte für dein Mutter allens gethan - ich wäre Stehlen gegangen - wenn ihr wat gefehlt hätte - ich hätte eingebrochen, ich wäre zum Verbrecher geworden - um ihr zu helfen! Else:

Mehr hab ich ja auch nicht gethan! (Auf Max deutend) ihm zu helfen - dat Geld ist von mir! ${ }^{4}$

\section{Appendix 4:}

Knolle:

Ja - das ist wahr Süssel, dein Max ist een anständiger Mensch!

Süssel:

Wenn alle Menschen so wären, wie du, dem jeder Mensch gleich is ob er Jud oder Christ, hätt ich nicht brauchen von Tuchel was aber so - e Gewalt! Mit e mal wird Tuchel verrückt - se woll's ka Süssel Holzer mehr! Gesehn - ausgerechnet Tuchel! Nu hab ich jemand was gethan? Haben nicht genug Menschen von mir gelebt? Bin ich nicht mit dir gestanden vor Gravelotte? Hätt ich nicht mein Leben ebenso gern fürs Vaterland geopfert, - hab ich nicht ebenso gut wie du Eltern zu Hause gehabt, 0 die geweint haben um ihr Kind? Mit e mal kriegen se e Ströhmung - Tuchel wird verrückt!

Knolle:

Ja ja det, Mensch, wirst du nicht ändern, det is allens Ansichtssache, da muss man eben darüber erhaben sein! Sieh mal, bringt zum Beispiel heut de Staatsbürger eenen Artikel, so'ne grosse Sache, lieber Jott, denn habe ich nen guten Tag und das Blatt wird gekooft, morgen bringt de Freisinnige eene neue Sensation denn mach ick detselbe Bombengeschäft, es hat alles 
ein Publikum, und das Schönste, die die de Staatsbürger Zeitung koofen - koofen auch de Freisinnige, dat is nu mal so'n Theater! Des sind Einbildungen, aber deswegen oller Junge, die Welt steht und wir beede werden se nicht ändern! ${ }^{5}$

\section{Appendix 5:}

Brünhilde:

Sie müssen doch meine Einladung bekommen haben?

Cohn:

Warum muss ich? Ich weiss von nichts!

Brünhilde:

Das sagen Sie blos, um ja nicht im Hause ihres Sohnes etwas essen zu müssen!

Cohn:

Schon wieder die alte Leier! Ich ess doch kein Treifes!

Brünhilde:

Wie kann man nur solch veraltete Ansicht haben?

Cohn:

E klügerer Mann wie ich - der grosse König Friedrich - hat mal ganz treffend bemerkt: "Lass Jeden selig werden nach seiner Facon."

Brünhilde:

Bleibt sich das jetzt nicht gleich, ob das Fleisch von Hefter oder von Rosenthal gekauft wird? Cohn:

Gewiss bleibt es sich gleich - warum kauft man da nicht von Rosenthal!

${ }^{4}$ Landesarchiv Berlin, Nachtdienst, Schauspiel aus dem Berliner Leben, Gebrüder Herrnfeld Theater, Rep. 30c/a, Theater Z, Neuer Teil 2320.

5 Landesarchiv Berlin, Nachtdienst, Schauspiel aus dem Berliner Leben, Gebrüder Herrnfeld Theater, Rep. 30c/a, Theater Z, Neuer Teil 2320. 
Brünhilde:

Komischer Mensch. ${ }^{6}$

\section{Appendix 6:}

Cohn:

Das Ende hab ich vorausgesehen, - die Tausender sind nur so rumgeflogen! Zu was hat er nötig gehabt, sich e anderen Namen beizulegen?

Abarbanell:

Das verstehn Sie nicht!

Cohn:

Ja das e Streich von e gesunden Menschen, wo der Vater noch bis hundert Jahr lebt - sich von e Baron als Sohn adoptieren zu lassen! - diese Adoption hat doch e Vermögen gekostet! Abarbanell:

Das war nicht so schlimm!

Cohn:

Er muss von Klamm-Cohn heissen! Cohn allein war euch nicht gut genug!

Abarbanell:

Cuhn allen ist heut kein Name mehr!

Cohn: wütend/

Millionen Cohns gibt's!

Abarbanell:

Das reicht nicht!

Cohn:

$\mathrm{Na}$ also!

Abarbanell:

${ }^{6}$ Landesarchiv Berlin, Salomonisches Urteil, Gebrüder Herrnfeld Theater, Rep. 30 c/a Theater 
Sie vergessen, dass Ihr Sohn in der G'sellschaft schon eine feste Position eingenommen hat! Cohn:

Die feste Postition hat'n es Genick gebrochen! Fife de Glockes hat er arrangieren müssen - Fife de Glockes! Nicht mal ausprechen kann ich's!

Abarbanell: $\mathrm{Na}$ ja - Sie sind's jetzt aufgeregt!

Cohn:

In de Luftbalons sind e hochgesteigen! auf de Leut Papierschnitzel runtergeschmissen! Überall war die Schwiegermama dabei - die alte Metzgerin!?

\section{Appendix 7:}

Moses:

Joseph ich bitte Dich noch einmal, nicht für mich, sondern für meinen Sohn. - Sieh - mein einziger Sohn geht heute ins Feld - und und - mit ihm tausende unserer Söhne aller Confessionen, und sie ziehen Seite and Seite, Schulter an Schulter in den Kampf, ohne zu fragen wie ist Deine Religion? Sie ziehen gemeinschaftlich in den Krieg um ihre Glaubensgenossen aus dem russischen Joch zu befreien, und der Jude wird nicht fragen, ist das nicht ein Katholik - den Du befreist? Der Katholik wird nicht fragen ist das nicht ein Mohamedaner, den Du befreist. - Nein - alle sie kennen keinen Unterschied in der Religion, weil es heisst für die Gerechtigkeit, für die Menschlichkeit einzutreten. Und Du der Du in der Stube hockst, Du willst anders denken? Das ist gemein von Dir -

Grieshuber: /aufbrausend/

Du kannst mich nicht durch Deine schön gefärbten Reden ja doch nicht umstimmen. Hat meine Tochter gegen den Willen Ihres Vaters gehandelt, so mag sie ihren Weg allein gehn Moses:

Z. Neuer Teil 4030.

7 Landesarchiv Berlin, Salomonisches Urteil, Gebrüder Herrnfeld Theater, Rep. 30 c/a Theater Z. Neuer Teil 4030. 
Warum hat sie gegen den Willen des Vaters gehandelt? Weil sie den Krieger leichteren Herzens in den Kampf ziehen lassen will. Sie hat sich für das Vaterland geopfert: Denn die heiligste Pflicht im Kriege gilt - zuerst Dein Vaterland, dann Deine Familie - und zuletzt erst Dein Glauben - 8

\section{Appendix 8:}

Wallowitzer:

Weil wir grad' so gemütlich beisammen sitzen, gestatten Sie, mein Name ist Wallowitzer.

Eichkutz:

Na Also! Isedor Eichkutz, meine Frau Sara.

Wallowitzer: (macht ein Kompliment.)

Ah, Sara, die biblische Stammmutter.

Eichkutz:

$\mathrm{Na}$ gar so alt ist meine Frau noch nicht.

Wallowitzer:

Na wegen die paar Tage.

Sara: (Zu Eichkutz)

Isedor, Du lässt mich hier so beleidigen.

Eichkutz: (Fährt drohend auf Wallowitzer los.) Sie! (Plötzlich mit einem Blick auf Sara in einem ruhigen Ton.) Sie haben doch nebbich recht. ${ }^{9}$

\section{Appendix 9:}

Charlé /:empört"/

Was? Ich ein Vaterlandsverräter?

${ }^{8}$ Landesarchiv Berlin, Er kommt wieder, Herrnfeld Theater, Rep. 30 c/a Theater Z. Neuer Teil $6015 a$.

9 Landesarchiv Berlin, III. Klasse, Folies Caprice, Rep. 30 c/a Theater Z. Neuer Teil 5049. 


\section{Hermann:}

Jawohl, das sind Sie, wenn Sie sich als Deutscher noch über falsche Nachrichten erfreuen. Glauben Sie denn, ich habe nicht gehört, wie Sie der alten Marianne fast glückstrahlend zugeflüstert haben, ja diesmal werden's die Deutschen wohl 'n bischen schwerer haben wie 1870. Aber oft verrechnet man sich, vielleicht auch die grosse Nation. Wir sind aber immerhin aufmerksam gegen die Herren Franzosen, und da wissen wir, dass sie auch gern Konfekt essen, haben wir ihnen ein paar $42 \mathrm{~cm}$-Pralinés offeriert. Die Dinger sind schwer zu verdauen und da kann man sich den Magen einwenig daran verderben. Die Herren Franzosen, die immer an der Spitze der Zivilisation marschieren und glauben, alle Vorzüge nur in der Einbildung vergrössert und in der Wirklichkeit verringert. Ja, ja der alte Zeppelin mit seinen Luftequipagen ist eine Erfindung, nicht? Und wir klatschen vergnügt in die Hände beim Anblick einer so mächtigen Leberwurst und rufen: Aller Segen kommt von oben. Und ob es uns diesmal schwerer fallen wird als wie 1870 , darüber werde ich mit Ihnen, Herr Charlé, nach dem grossen Krieg wohl nicht mehr sprechen können. Mir hat man ein Doktor gesagt, wenn ich gesund bleiben will, dann muss ich alles unangenehme vergessen, und wissen sie, wo ich anfangen werde zu vergessen, bei Ihnen, Herr Charlé. ${ }^{10}$

\section{Appendix 10:}

Die Leute vom Kurfürstendamm:

'S gibt in Berlin nen kleinen Kreis,

Der "Tout Berlin" sich nennt,

Wo jeder was vom anderen weiss,

Wo sich ein jeder kennt;

Wer was hat, wer was kann,

Wer sich nennt comme il faut,

${ }^{10}$ Landesarchiv Berlin, Fest steht und treu... oder sein froh daß du ein Deutscher bist, Folies 
Aus dem Tiergartenviertel

Aus der Gegend vom Zoo,

Und die Leute vom Kurfürstendamm--

Alle zusamm', alle zusamm'!

Wer ist bei den Diners, Soupers,

Man immer wieder trifft?

Wer glänzt bei allen Comitees

Durch Namensunterschrift?

Wen findet man im Tatternsaal

Und bei den five o clocks?

Wen grüßt man auf dem Presseball,

Bei Nikisch, Siegfried Ochs?

Und wer geht spazieren behaglich und froh

Im Sommer des abends da draussen im "Zoo"

In der Lästerallee bei Thinbumm und Trara?

$\mathrm{Ja}$ alle alle alle alle alle sind sie da. $" 1$

\section{Appendix 11:}

Junge: ...Wer ist jenne?

Compere: Was heißt jenne?

Junge: Nu - dort - das Schickselchen, sie Gannew!

Compere: Das ist meine Frau du Bengel.

Junge: Oi! Oi! Oi! Was manche Menschen für Glück haben! Allen jüdischen Kinder gesagt!

Caprice, Rep. 30 c/a Theater Z. Neuer Teil 6043.

11 Landesarchiv Berlin, Das muß man sehn, Metropol Theater, 1907, Rep. 30 c/a, Theater Z, Neuer Teil. 
Sie! Darauf müssen Sie gut gut aufpassen, auf sowas giebt's Nascher.

Commere: Wir sind auf der Hochzeitsreise.

Junge: Ich weiss! Ich weiss Alles! Wir Kinder werden jetzt schon in der Vorschule über Alles aufgeklärt! Das ist die moderne Richtung!

Compere: Mich interessierst Du hauptsächlich, weil Du ein ausgetauschtes Kind bist.

Junge: Stimmt, stimmt. Wie Sie mich zum Beispiel jetzt kennen gelernt haben, werden Sie ganz erstaunt sein, wenn Sie hören, wer ich bin.

Compere: Nun also mein Junge, wer bist du?

Junge: Ich bin der Sohn vom Grafen Pückler. ${ }^{12}$

\section{Appendix 12:}

Der kleine Pückler: (komischer Junge in Matrosenanzug; leicht jüdischer Accent):

Das ist mir großartig gelungen! Ich habe dem Mann an der Kasse gesagt, dass ich noch nicht zehn Jahre alt bin, da hat er mir ein Kinderbillet gegeben! Nu nein! Genieren werd' ich mich! Was braucht der Mann zu wissen, das ich schon Barmizwah gemacht habe?

Compere: Der Bursche interessiert mich. Guten Tag, Kleiner.

D. kl. Pückler: Wieso Kleiner? Was heißt hier Kleiner? Was belieben Sie von mir zu wünschen?

Compere: Du interessierst mich, Junge, weil man mir gesagt hat, dass Du ein ausgetauschtes Kind bist.

D. kl. Pückler: Stimmt, stimmt. Ich bin ein ausgetauschtes Kind! Wir Kinder werden jetzt immer für ein paar Monate in ganz neue, ganz von unseren Gewohnheiten verschiedene Umgebungen gebracht, damit sich unser Ponimkreis erweitert.

Compere: Was für ein Kreis?

D. kl. Pückler: Nu - Ponimkreis! Gesichtskreis, wenn Sie das besser versteh'n.

12 Landesarchiv Berlin, Das muß man sehn! Metropol Theater, 1907, Rep. 30 c/a Theater Z, 
Compere: Darf man fragen wie alt Du bist?

Pückler: (befühlt seine Anzug) Grossartiger Stoff, was Sie da haben? Was haben Sie bezahlt für den Meter?

Compere: Ich wünsche zu wissen, wie alt du bist.

Pückler: Zehn Jahr --- bis hundert!

Compere: Das ist eine etwas ungenaue Zeitangabe - ich bitte etwas präciser.

Pückler: Nu ich sag doch --- zehn bis hundert.

Commere: Da müssen Sie anders fragen. Wie alt bis hundert Jahr bist Du?

Pückler: Zehn Jahr, Seh'n Sie so fragt man.

Compere: Und wohin geht die Reise?

Pückler: Wo werd' ich hinreisen?

Compere: Merkwürdig, dass Thr immer eine Frage mit einer Gegenfrage beantwortet!

Pückler: Wieso frag ich? Übrigens, wenn es Sie gar zu sehr interessiert, ich fahr nach Klein Tschirne!

Compere: Waas? Klein -Tschirne??

Pückler: Ja, aber ich bin unberufen zu gesund sechs Monate als ausgetauschtes Kind bei die Gebrüder Hermfeld in Pension gewesen.

Compere: Junge Junge, ich glaube, Dein Papa wird vor Wut platzen, wenn er dich so wiedersieht.

Pückler: Nu wenn schon! Platzt er - platzt er! An die antisemitischen Schmonzes glaub ich sowieso nicht mehr. Den roten Manasse habe ich sogar persönlich kennen gelernt und er ist ein sehr netter, gediegener Mensch kann ich Thnen sagen. Ja! Und alle Abend bin ich bei meine Pflegeeltern im Theater gewesen! Da hab ich noch kennen gelernt -- was man so nennt -Heimatkunst!!

Compere: Und inzwischen - wenn ich recht verstehe - war die kleine Herrnfeld zu ihrer

Neuer Teil. 
Fortbildung auf Klein -Tschime?

Pückler: Ein sehr bescheidenes Mädel sogar! Ich bin sehr neugierig, wie die ihren Gesichtskreis erweitert hat. ${ }^{13}$

\section{Appendix 13:}

Die Vorigen, die kleine Hermfeld:

Hermfeld: (sehr flott herein, mit Reitpeitsche etc, etc)

Donnerwetter noch mal, Glück, dass endlich in Berlin angelangt bin! War während ganzer Fahrtdauer zusammengepfercht mit lauter Kommis und Handelsbeflissenen! Skandalös, wie diese Fremdlinge mit mir kokettiert haben.

Pückler: Das is se, das is se!

Compere: Wenn mich nicht Alles täuscht, hab ich das Vergnügen mit -Herrnfeld: Fräulein Herrnfeld, Rosalie Herrnfeld, Tochter der Gebrüder Herrnfeld, als ausgetauschtes Kind 6 Monate bei Pückler auf Klein Tschime ( Auf den Buben zu) Tag Teut! Deutschen Händedruck!

Pückler: Grüss Gott, Salchen, Du siehst unberufen sehr gut aus.

Hermfeld: Ist mir auch nichts abgegangen da draussen bei Deinem alten Herrn, in der frischen schönen Landluft. Ich beneide Dich förmlich! Jetzt wirst Du bald wieder auf die Jagd gehen! Pückler: Wieso ich? Hayfisch geht zur Jagd!

Herrnfeld: Wirst wieder flotte Attacken reiten!

Pückler: Nein! Nein! Ich bin sechs Monate bei den Herrnfelds gewesen - ich steig auf kein Pferd mehr!

Hermfeld: Und ich werde all die netten, ulkigen Abende nicht mehr miterleben, wenn Dein Papa so vom Podium heruntergedonnert hat, bis der Blaue die Mütze aufsetzte und uns auflöste.

${ }^{13}$ Landesarchiv Berlin, Das muß man sehn! Metropol Theater, 1907, Rep. 30 c/a Theater Z, 
Pückler: Es wird Dir nichts abgehen, Deine Leute reden auch von Podium herunter (und sind auch ganz gute Komiker./ von der Zensur gestrichen)

Compere: Ich sehe mit Vergnügen, dass das System vortrefflich ist, dass die jungen Herrschaften durch den Austausch die Lücken ihres Wesens in wahrhaft wunderbarer Weise ausgefüllt haben. ${ }^{14}$

\section{Appendix 14:}

Der Herr:

Der verdammte Esel von Lohndiener goss meiner Tischdame die ganze Mousselinsauce in den Ausschnitt und weil ich selbst keine Sauce mehr hatte, hab ich meinen Stangenspargel da rein gestippt. Tata! Finden sie was dabei? Und den Unglücksabend bei Kohns neulich werde ich in meinem ganzen Leben nicht vergessen. Es war Polterabend. Beim Eintreten sagte mir Frau Kohn, dass ich zum Courmachen engagiert bin, aber ausschliesslich für die Missniks, damit die sich nicht mopsen. "Sehr wohl" sag ich und steure sofort auf das grösste Menubbl im ganzen Sall los, da fällt Frau Kohn beinahe in Ohnmacht - es war die Braut! Tata! Um meine Aufregung zu beschwichtigen eilte ich zum Büffet und as sechs Portionen Eis. Da schreit Kohn: "Nehmen Sie etwas mehr Rücksicht und weniger Eis, ich habe Sie als Tanzbär engagiert und nicht als Eisbär!" diese Roheit schlug mir auf den Magen, daß Eis rebellierte in mir, ich wurde schwach und setzte mich unvorsichtiger Weise vor der ganzen Gesellschaft auf den Topf

Commere:

Um Gotteswillen!

Compere:

Worauf haben Sie sich gesetzt??

Neuer Teil.

14 Landesarchiv Berlin, Das muß man sehn! Metropol Theater, 1907, Rep. 30 c/a Theater Z, Neuer Teil. 


\section{Der Herr:}

Ausreden lassen. Ausreden lassen. Auf den Topfhut einer Dame, den ich in meiner Dusseligkeit gar nicht bemerkt habe. Finden Sie was dabei? Tata!'15

\section{Appendix 15:}

Die Direktrice (Aufgeregt, vom großen Publikum gefolgt)

"Elf Uhr - der grosse Moment ist gekommen! Ich fiebrige vor Aufregung - Treten Sie ein, meine Damen . - Bitte Platz zu nehmen, die Mitte muß frei bleiben.

Der Chef:

Elf Uhr! Er ist da! Er ist da! (zur Direktrice) Sie haben doch dafür gesorgt, dass alle Eingänge gesperrt und nur die Intimsten des Hauses mit Einlasskarten zugelassen werden.

Direktrice:

Selbstverständlich!

Herr Cohn zu seiner Frau:

Rosalie - Beruhige Dich! Sei nicht so aufgerogen! Er wird Dich ansehen, er wird Dir massnehmen - aber schliesslich - Zauberer ist er auch nich!

Der Chef:

Ruhe, Ruhe, meine Herrschaften! Der historische Augenblick ist da! (ein Gongschlag). Schon tönt der Gong!

Herr Cohn:

Heisst e Gegonkel wegen dem Onkel!

(Probierdamen schlängeln sich bei leiser Musik über die Treppen herunter durch die Vorhänge und machen ihre Promenade von allen begafft und longnettiert.)

Der Backfisch:

Was für entzückende Mädchen.

15 Landesarchiv Berlin, Hallo!! Die grosse Revue Metropol Theater, 18.10.1909, Rep. 30 c/a 


\section{Herr Cohn:}

Besicheinte Schickses! Seh' Dir nur, wie se sich schlängeln.

Frau Cohn:

Seh' weg, Isisdor!

Der Chef:

Das sind die Mannequins.

\section{Herr Lehmann:}

Wat heest Manekens? Ik hab det für Weiberkens gehalten!

(wieder zwei Gongschläge)

Der Chef:

Ruhe! Ruhe! Stimmung! Stimmung! Schnell, schnell die Weihrauchfässchen! Der Vorhang geht auf! Jetzt! Jetzt!

(Der Vorhang teilt sich unter feierlichen Gesang, während die Mannequins Weihrauchfässchen schwingen. Auf einem Trohn, von den knieenden Konfektionären umgeben - sitzt Poiret, über den mehrere Probierdamen einem goldenen Lorbeerkranz halten) ${ }^{16}$

\section{Appendix 16:}

Poiret:

Jetzt werden sie sehen, was das Genie von eine Poiret kann verwandeln en cinq minute la femme la plus laide -- die hässlichste Frau - la femme la plus terrible - die schauerlichste Frau (Sucht im Kreise)

Herr Cohn:

Rosalie - Stell' dich vor!

Theater Z, Neuer Teil 4559.

${ }^{16}$ Landesarchiv Berlin, Die Nacht von Berlin, Metropol Theater, Rep. 30 c/a, Theater Z, Neuer Teil, 5140. 
Poiret (Frau Cohn erfassend und mit einem Ruck zu sich ziehend) Madame!

Frau Cohn:

Quel bonheur!

Poiret:

Ce costume! Quel blamage! Quel desastre! Desagreable! Weg damit! Weg! Weg! Weg!

(Reisst ihr das aus Papier gefertigte Kleid in Fetzen herunter, so dass sie in drolliger

Untertoilette dasteht)

Herr Cohn:

Poiret! Was machen Sie mein Unglück so öffentlich!

Poiret:

Silence! Silence! Stören Sie nicht mein Inspiration!

Ah! La portiere! (Stürzt auf die Portiere zu, reisst sie herunter und umwickelt damit Frau Cohn, deren Constum so eingerichtet ist, dass sie sich beim Umwickeln aus einer Korpulenten in eine magere Figur verwandelt.

Amandine - les Cheveux (ein Manequin reicht ihn die hohe Frisur, die er ihr aufstülpt (un chapeau! Un chapeau! Ah - Voila -

(nimmt einen kleine Papierkorb)

Superb, ravissement! Mais la corde, la corde! Wo sein einer Schnur, einer Schnur?

$[\ldots]$

Alle:

Bravo!

Herr Cohn:

Rosalie- Du siehst aus, wie die Kronprinzessin von Posen!

Poiret:

Und in einer Woche, wann werden sein vorüber der Revue -- kehr ich zurück nach Paris!17

${ }^{17}$ Landesarchiv Berlin, Die Nacht von Berlin, Metropol Theater, Rep. 30 c/a, Theater Z, Neuer 


\section{Appendix 17:}

En revenant de la revue

Kehr ick retour dann nach Paris

Von meine grande gloire sein plein

'Figaro', 'Temps', 'Journal', 'Matin'

der Taschen voll mit deutsse Geld,

zugleich ein Schneider und ein Held,

erzähl ik auf die Boulevard -

Wie für revanche ik tätik war!

Im Jahre Siebssig ein,

Im Glanz des Glorienscheins,

Da hat Allemagne gehabt la chance,

Gekriegt Milliarden von la France,

Dok wenn von früh bis spät,

Geschäft so weiter geht,

Dann bring ik bald zurück mit Schwung

Der ganze Kriegsentschädigung!

Kein Boulanger

Und auch kein Delcasse

Hat Deutschland so geführet en der Neese

Nur Poiret leert ihm das portemonaie!

C'est la revanche

De la nation francaise ${ }^{18}$

Teil, 5140.

${ }^{18}$ Landesarchiv Berlin, Metropol Theater, Die Nacht von Berlin, Rep. 30 c/a Theater Z, Neuer Teil, 5140. 


\section{Bibliography}

This study is based on three principal types of sources -- private, press and police records. Many of the important materials for this study can be found in the archives of the former GDR. These contain a surprisingly large and rich array of materials, including newsletters, legal documents, photos, programs, and directories of workers in the field of entertainment. In contrast to sources relevant to political history, which can be found in official state archives, pertinent material for performers is often dispersed in private hands. In order to gain access to such material it was crucial to win the confidence of descendants of performers in the industry. They supplied unpublished diaries and letters from both prominent and obscure Jewish entertainers, allowing insights into family relations and traditions, friendships, humor and personal views on politics.

These documents are supplemented with newspaper reports published in national papers, such as the Vossische Zeitung, the Berliner Tageblatt or the Berliner Börsen-Courier. The treatment of entertainment in the national daily newspapers allowed me to explore the degree to which popular culture represents an independent microcosm or a direct reflection of society at large. The many contemporary artistic journals such as Der Artist, Das Organ or Das Programm provided information on the professional lives of German entertainers, including their artistic unions and work conditions, their wages and travel routes, as well as their work ethics and self-promotion as professionals. Finally, this study relied on police records which include the censured texts of plays, the comments of the police agents, and the decisions taken by the president of the police. These sources shed light on the role of the state, antisemitism, morality and censorship in German society between 1890 and 1933 . 


\section{Archives}

Akademie der Künste, Berlin

Brandenburgisches Landeshauptarchiv, Potsdam

Circus-Busch-Archiv, Berlin

Circus, Varieté- und Artistenarchiv, Marburg

Deutsches Kabarett Archiv/Reinhard Hippen, Mainz

Documenta Artistica Collection in the Märkisches Museum, Berlin

Landesarchiv Berlin

Landeshauptarchiv Sachsen Anhalt, Magdeburg

Theaterhistorische Sammlung Unruh, Freie Universität, Berlin

Yad Vashem, Jerusalem

\section{Published Sources}

Bethge, Hans. Lieder an eine Kunstreiterin. Berlin, 1922.

Buchner, Eberhard. Varietés und Tingeltangel in Berlin. Berlin, 1905.

Busch, Paula. Das Spiel meines Lebens: Erinnerungen. Berlin, 1992.

Clara, Sandra. Die Mode im Spiegel des Krieges. Essen and Cologne, 1915.

Compardon, Emil. Les Spectacles de la Foire. Paris, 1877.

Dohm, Christian Wilhelm. Concerning the Amelioration of the Civil Status of the Jews. Translated by Helen Lederer. Readings in Modern Jewish History, edited by E. Rivkin, Cincinetti, 1957.

Giese, Fritz. Girlkultur, Vergleich zwischen amerikanischem und europäischem Rhythmus und Lebensgefühl. Munich, 1925.

Hagenbeck, Carl. Von Menschen und Tieren: Erlebnisse und Erfahrungen. Leipzig, 1928. 
Halperson, Joseph. Das Buch vom Zirkus, Beisträge zur Geschichte der Wanderkünstlerwelt. Düsseldorf, 1926.

Herlitz, G., and B. Krrschner, eds. Jüdisches Lexikon. Berlin, 1927-1930.

Ihering, Herbert. Berliner Dramaturgie. Berlin, 1947.

Kaes, Anton, Martin Jay and Edward Dimenberg, eds. The Weimar Republic Sourcebook. Berkeley, CA, 1995.

Moszkowski, Alexander. Der jüdische Witz und seine Philosohie. 399 Juwelen echt gefaßt von Alexander Moszkowski. Berlin, 1922.

Rönnebeck, R. "Theater und Circusgebäude." In Berlin und seine Bauten. Berlin, 1896.

Satarino, Signor. Artisten-Lexikon. Biographische Notizen über Domteure, Gymnastiker, Clowns, Akrobaten ... aller Länder und Zeiten. Leipzig, 1896. Reprinted in Roland Weise, Bibliotheca artistica. Die bunte Welt vom Varieté, Zirkus und Schaustellerwesen. I, Leipzig, 1987.

Schmitt, Eduard. Handbuch der Architektur, Vierter Teil. Entwerfen, Anlage und Einrichtug der Gebäude, 6. Halbband, Gebäude für Erziehung, Wissenschaft und Kunst, 6. Heft, Zirkus- und Hippodromgebäude. Stuttgart, 1904.

Seelig, Ludwig. Geschäftstheater oder Kulturtheater? Berlin, 1914.

Schütte, Jürgen and Peter Sprengel, eds. Die Berliner Moderne 1885-1914. Stuttgart, 1993.

Szatmari, Eugen. Das Buch von Berlin. Munich, 1927.

Turszinsky, Walter. Berliner Theater. Berlin, 1906.

Verein deutscher Dichterfreunde, ed. Album Schlesischer Dichterfreunde 7, Breslau, 1874.

Weber, A.O. Berlin und die Berliner. Berlin, n.d..

Zedlers Universallexikon (reprint). Zürich, 1961. 


\section{Secondary Literature}

Abrams, Lynn. "From Control to Commercialization: the Triumph of Mass Entertainment in Germany 1900-25?" German History 8 (1990): 278-293.

Abrams, Lynn. Workers' Culture in Imperial Germany: Leisure and Recreation in the Rhineland and Westphalia. London, 1992.

Abrams, Lynn. "Zur Entwicklung einer kommerziellen Arbeiterkultur im Ruhrgebiet." In Kirmes-Kneipen-Kino: Arbeiterkultur im Ruhrgebiet zwischen Kommerz und Kontrolle (1850-1914), edited by Dagmar Kift, 33-59. Paderborn, 1992.

Allen, Ann Taylor. "Women's Studies as Cultural Movement and Academic Discipline in the United States and West Germany: The Early Phase, 1966-1982." Women in German Yearbook 9 (1993): 1-23.

Anderson, Margaret Lavinia. "Piety and Politics: Recent Work on German Catholicism." Joumal of Modern History 63 (1991): 681-716

Angress, Werner T. "Das deutsche Militär und die Juden im ersten Weltkrieg." Militärgeschichtliche Mitteilungen 19 (1976): 77-146.

Angress, Werner T. "The German Army's 'Judenzählung' of 1916: Genesis-ConsequencesSignificance." Leo Baeck Institute Year Book 23 (1978): 117-137.

Amold, Hermann. Fahrendes Volk: Randgruppen des Zigeunervolkes. Landau, Pfalz, 1983.

Aschheim, Steven E. "'The Jew Within': The Myth of 'Judaization' in Germany." In Jehuda Reinharz and Walter Schatzberg, ed. The Jewish Response to German Culture: From the Enlightenment to the Second World War, 212-241, Hanover, NH, 1985.

Aschheim, Steven E. Brothers and Strangers: East European Jews in German and GermanJewish Conciousness, 1800-1923. Madison, WI, 1982.

Assmann, Aleida. Arbeit am nationalen Gedächtnis. eine kurze Geschichte der deutschen Bildungsidee. Frankfurt a. M., 1993.

Barth, Fredrik. "Introduction." In idem., Ethnic Groups and Boundaries: The Social Organization of Culture Difference. Bergen, 1969, pp. 9-38.

Baumgarten, F. Zirkus Reinhardt. Potsdam, 1920.

Hermann Bausinger. "Bürgerlichkeit und Kultur." In Bürger und Bürgerlichkeit im 19. Jahrhundert, edited by Jürgen Kocka, 121-141. Göttingen, 1987.

Beaufis, Marcel. Comment l'Allemange est devenue musicienne. Paris, 1983.

Bemmann, Helga, ed. Die Artisten, ihre Arbeit und ihre Kunst. Berlin, 1965.

Benjamin, Walter. Gesammelte Schriften.. Frankfurt a. M., 1972. 
Bennett, Tony. The Birth of the Museum: History, Theory, Politics. London, 1995.

Berding, Dietz. The Stigma of Names: Antisemitism in German Daily Life, 1812-1933. Ann Arbor, MI, 1992.

Berding, Helmut. Moderner Antisemitismus in Deutschland. Frankfurt a. M., 1988.

Berger, Roland and Dietmar Winkler. Künstler, Clowns und Akrobaten, Der Zirkus in der bildenden Kunst. Berlin, 1983.

Berghahn, Marion. German-Jewish Refugees in England. London, 1984.

Berkfeld, Henning, ed. Hamburg in alten und neuen Reisebeschreibungen. Düsseldorf, 1990.

Bessel, Richard. Germany after the First World War. Oxford, 1993.

Bhabha, Homi. The Location of Culture. London, 1994.

Blackbourn, David and Richard Evans, eds. The German Bourgeoisie. Essays on the social history of the German middle class from the late eighteenth to the early twentieth century. London, 1991.

Blackbourn, David. Marpingen: Apparitions of the Virgin Mary in Bismarckian Germany. Oxford, 1993.

Blaschke, Olaf. Katholizismus und Antisemitismus im Deutschen Reich. Göttingen, 1997.

Blaschke, Olaf, and Frank-Michael Kuhlemann, eds. Religion im Kaiserreich: Milieus, Mentalitäten, Krisen. Gütersloh, 1996.

Bloch, Ernst. Das Prinzip Hoffnung. In Idem., Gesamtausgabe, vol. 5, Frankfurt a. M., 1959.

Boehlich, Walter. ed. Der Berliner Antisemitismusstreit. Frankfurt a. M., 1965.

Bose, Günther and Erich Brinkmann. Circus. Geschichte und Ästhetik einer niederen Kunst. Berlin, 1978.

Bose, Günther and Erich Brinkmann. "Heimweh nach die Reise." In Fahrendes Volk: Spielleute, Schausteller, Artisten. Exposition Catalogue, May 2 to July 4, 1981, Städtische Kunsthalle Recklinghausen.

Bouissac, Paul. Circus and Culture: A Semiotic Approach. Bloomington, 1976.

Brändel, Rea. Wildfremd, hautnah: Völkerschauen und Schauplätze Zürich 1880-1960. Zürich, 1995.

Brenner, Michael. The Renaissance of Jewish Culture in Weimar Germany. New Haven, CT, 1996.

Briggs, Asa. Mass Entertainment: The Origins of a Modern Industry. Adelaide, 1960.

Brüggemeier, Franz-Josef and Jürgen Kocka, eds. "Geschichte von unten - Geschichte von innen. " Kontroversen um die Alltagsgeschichte. Hagen, 1985. 
Brunner, Otto. Neue Wege der Sozialgeschichte. Göttingen, 1956.

Budde, Gunilla-Frederike. Auf dem Weg ins Bürgerleben: Kindheit und Erziehung in deutschen und englischen Bürgerfamilien. Göttingen, 1994.

Budzinski, Klaus. Die Muse mit der scharfen Zunge: Vom Cabaret zum Kabarett. Munich, 1961 .

Budzinski, Klaus. Pfeffer ins Getriebe. So ist und wurde das Kabarett. Munich, 1982.

Burns, Rob, ed. German Cultural Studies: An Introduction. Oxford, 1995.

Calhoun, Craig. ed. Habermas and the Public Sphere. Cambridge, MA, 1992.

Carlé, Wolfgang. Das hat Berlin schon mal gesehn: Eine Historie des Friedrichstadt-Palaste. Berlin, 1982.

Chickering, Roger. We Men Who Feel Most German: A Cultural Study of the Pan-German League, 1886-1914. Boston, 1984.

Chombard-Gaudin, Cecile. "Frankreich blickt auf Berlin 1900-1939." In Metropolis Berlin. Berlin als deutsche Hauptstadt im Vergleich europäischer Hauptstädte 1871-1939, edited by Gerhard Brunn and Jürgen Reulecke. 367-407, Bonn, 1992.

Cohen, S. B., ed. From Hester Street to Hollywood: The Jewish-American Stage and Screen. Bloomington, 1983.

Dahlhaus, Carl. Die Musik des 19. Jahrhunderts. Wiesbaden, 1980.

Danckert, W. Unehrliche Leute: Die verfehmten Berufe. Bern and Munich, 1963.

Daniel, Ute. Hoftheater. Stuttgart, 1995.

Derk, Hans. "Über die Faszination des 'ganzen Hauses."' Geschichte und Gesellschaft 22 (1996): 221-242.

Düring, Dieter. Organisierter gesellschaftlicher Nationalismus in Deutschland (1808-1847): Bedeutung und Funktion der Turner- und Sängervereine fuir die deutsche Nationalbewegung. Munich, 1984.

Dussel, Konrad, and Mathias Frese. "Von traditioneller Vereinskultur zu moderner Massenkultur? Vereins- und Freizeitangebote in einer südwestdeutschen Kleinstadt 19201960." Archiv für Sozialgeschichte 33 (1993): 59-105.

Eberstaller, G. B., and Paul Christian. Circus. Wien, 1976.

Eksteins, Modris, Rites of Spring. The Great War and the Birth of the Modern Age. Toronto, 1989.

Eriksen, Thomas Hylland. Ethnicity and Nationalism: Anthropological Perspectives. London, 1993.

Feld, Hans. "Jews in the Development of the German Film Industry: Notes from the 
Recollections of a Berlin Film Critic." Leo Baeck Institute Year Book (1982), XXVII: 337-368.

Fetting, Hugo, ed. Max Reinhardt Schriften, Briefe, Reden, Aufsätze, Interviews, Gespräche, Auszüge aus Regiebüchern. Berlin, 1974.

Feuerstein, Karl Heinz. "Vom Ankündigungsplakat zum Schaustellerplakat." In Menschen, Tiere, Sensationen, Zirkusplakate 1880-1930, edited by Carl-Albrecht Haenlein and Wolfgang Till, May 5 to June 18, 1978, exhibition catalogue, Hannover.

Fischer-Lichte, Erika. Die Entdeckung des Zuschauers: Paradigmenwechsel auf dem Theater des 20. Jahrhundert. Tübingen, 1997.

Fischer-Lichte, Erika. The Show and the Gaze of the Theatre. A European Perspective. Iowa City, 1997.

Fladt, H. Musik im 19. Jahrhundert: Aspekte bürgerlicher Musikkultur. Stuttgart, 1981.

Freitag, Winifried. "Haushalt und Familie in traditionalen Gesellschaften: Konzepte, Probleme und Perspektiven der Forschung." Geschichte und Gesellschaft 14 (1988): 5-37.

Fremdling, Rainer. Eisenbahnen und deutsches Wirtschaftswachstum, 1840-1979. Dortmund, 1975.

Fremdling, Rainer, Ruth Federspiel, and Andreas Kunz, eds. Statistik der Eisenbahnen in Deutschland 1835-1989. St. Katharinen, 1995.

Freud, Siegmund. Der Witz und seine Beziehung zum Unterbewußten: Der Humor. Frankfurt a. M., 1992.

Freund, Walter. "Aus der Frühzeit des Berliner Metropoltheaters," Kleine Schriften der Gesellschaft für Theatergeschichte 19 (1962).

Frevert, Ute. Ehrenmänner: Das Duell in der bürgerlichen Gesellschaft. Munich, 1991.

Frevert, Ute, ed. Militär und Gesellschaft im 19. und 20. Jahrhundert. Stuttgart, 1997.

Freydank, Ruth. Theater in Berlin: Von den Anfängen bis 1945. Berlin, 1988.

Freydank, Ruth. Theater als Geschäft. Berlin, 1995.

Friedländer, Saul. "Die politischen Veränderungen der Kriegszeit und ihre Auswirkungen auf die Judenfrage." In Werner E. Mosse, ed. Deutsches Judentum in Krieg und Revolution 1916-1923. 27-67, Tübingen, 1971.

Fritzsche, Peter. A Nation of Fliers: German Aviation and the Popular Imagination. Cambridge, MA, 1992.

Fritzsche, Peter. Reading Berlin 1900. Cambridge, MA, 1996.

Gabler, Neal. An Empire of Their Own: How the Jews Invented Hollywood. New York, 1988.

Gallagher, Catherine and Thomas Laqueur, eds. The Making of the Modern Body: Sexuality 
and Society in the Nineteenth Century. Berkeley, CA, 1987.

Gay, Peter. Freud, Juden und andere Deutsche. Munich, 1989.

Gay, Peter. Weimar Culture. The Outsider as Insider. London, 1969.

Gay, Peter. Erziehung der Sinne. Sexualität im bürgerlichen Zeitalter. Munich, 1986.

Geller, Rudolf. "Die Familie Blumenfeld und ihre Circusse." Die Zirkuszeitung, Kulturhistorische Gesellschaft für Circus und Varietékunst June, 1992.

Geyer, Michael, and Konrad H. Jarausch. "Great Men and Postmodern Ruptures: Overcoming the 'Belatedness' of German Historiography." German Studies Review 18 (1995): 253273.

Gilman, Sander. Jewish Self-Hatred. Antisemitism and the Hidden Language of the Jews. Baltimore and London, 1986.

Gilman, Sander. Smart Jews: The Construction of the Image of Jewish Superior Intelligence. Lincoln, NE, 1996.

Gobbers, Emil. Artisten, Zirkus und Variete in alter und neuer Zeit. Düsseldorf, 1949.

Goltermann, Svenja Der Körper der Nation. Göttingen, 1998.

Graml, Herman. "Modern Antisemitism in Germany." in Handbuch zur "Völkischen Bewegung," Munich, 1996.

Groth, Lothar. Die starken Männer: Geschichte der Kraftakrobatik. Berlin, 1987.

Gumbrecht, Hans Ulrich. In 1926: Living at the Edge of Time. Cambridge, MA, 1997.

Günther, Ernst. Geschichte des Varietés. Berlin, 1981.

Günther, Ernst and Dietmar Winkler. Zirkusgeschichte. ein Abriß der Geschichte des deutschen Zirkus Berlin, 1986.

Haberland, Wolfgang. "Diese Indianer sind falsch': Neun Bella Coola im Deutschen Reich 1885/86," Archiv für Völkerkunde 42 (1988):

Hall, Stuart. "Cultural Studies: Two Paradigms." In Culture/Power/History, edited by Nicholas B. Dirks, Geoff Eley, and Sherry B. Ortner. Princeton, NJ, 1994.

Hansen, Miriam. Babel \& Babylon: Spectatorship in American Silent Film. Cambridge, MA, 1994.

Heinrich-Jost, Ingrid. Sehn Sie, das ist ein Geschäft, Auf ins Metropol, Spezialiäten- und Unterhaltungstheater im ausgehenden 19. Jahrhundert, Ein Kapitel Berliner Kulturgeschichte. Berlin, 1983.

Heinrich-Jost, Ingrid. Hungrige Pegasusse. Anfänge des deutschen Kabaretts in Berlin. Berlin, 1984.

Heuberger, Georg, ed. Zedaka: Jüdische Sozialarbeit im Wandel der Zeit. Frankfurt a. M., 
1992.

Hoberman, J. Bridge of Light: Yiddish Film Between Two World Wars. Philadelphia, 1991.

Hösch, Rudolf. Kabarett von gestern. Nach zeitgenössischen Berichten, Kritiken und Erinnerungen, 1900-1933. vol. 1. Berlin, 1967.

Holländer, Friedrich. Von Kopf bis Fuss. Mein Leben mit Text und Musik. Bonn, 1996.

Howard, Michael. War in European History. London, 1975.

Hunt, Lynn, ed. The New Cultural History. Berkeley, CA, 1989.

Hyman, Paula E. Gender and Assimilation in Modern Jewish History. Seattle and London, 1995.

Hyman, Paula E. The Emancipation of the Jews of Alsace: Acculturation and Tradition in the Nineteenth Century. New Haven, CT, 1991.

Ihering, Herbert. Berliner Dramaturgie. Berlin, 1947.

Jäger, Christian and Eberhard Schütz, eds. Glänzender Asphalt. Berlin im Feuilleton der Weimarer Republik. Berlin, 1994.

Jameson, Egon. Am Flügel: Rudolf Nelson. Berlin, 1967.

Jameson, Egon. Mein lustiges Spree-Athen. Berlin, n.d..

Jansen, Wolfgang. Das Varieté, Die glanzvolle Geschichte einer unterhaltenden Kunst. Berlin, 1990.

Jansen, Wolfgang. Glanzrevuen der zwanziger Jahre. Berlin, 1987.

Jeismann, Michael, and Rolf Westheider. "Wofür stirbt der Bürger? Nationaler Totenkult und Staatsbürgertum in Deutschland und Frankreich seit der Französischen Revolution." In Der politische Totenkult: Kriegerdenkmäler in der Moderne, edited by Reinhard Koselleck and Michael Jeismann. Munich, 1994.

Jelavich, Peter. Berlin Cabaret. Cambridge, MA, 1993.

Jones, Robert A. Art and Entertainment: German Literature and the Circus, 1890-1933. Heidelberg, 1985.

Kampe, Norbert. Studententum und "Judenfrage" im Kaiserreich. Göttingen, 1988.

Kaplan, Marion A. The Making of the Jewish Middle Class: Women, Family, and Identity in Imperial Germany. New York, 1991.

Katz, Jacob. Vom Vorurteil zur Vernichtung. Munich, 1989.

Kauders, Anthony. German Politics and the Jews: Dïsseldorf and Nuremberg, 1910-1933. Oxford, 1996.

Kehr, Eckart. "Zur Genesis des Königlich Preußischen Reserveoffiziers.” In Idem, Das Primat 
der Innenpolitik: Gesammelte Aufsätze zur preußisch-deutschen Sozialgeschichte im 19. und 20. Jahrhundert. 53-63, Berlin, 1965.

Keitz, Christine. Reisen als Leitbild: Die Entstehung des modernen Massentourismus in Deutschland. Munich, 1997.

Klooss, Reinhardt, and Thomas Reuter. Körperbilder, Menschenornamente in Revuetheater und Revuefilm. Frankfurt a. M., 1980.

Klünner, H. W. Zirkusstadt Berlin, 165 Jahre: Eine Chronologie der Zirkusbauten an der Spree. Berlin, n.d.

Knodel, John E. The Decline of Fertility in Germany, 1871-1939. Princeton, NJ, 1974.

Kobrin, Frances E., and Calvin Goldschneider. The Ethnic Factor in Family Structure and Mobility. Cambridge, MA, 1978.

Kocka, Jürgen. Klassengesellschaft im Krieg 1914-1918. Göttingen, 1973.

Kocka, Jürgen. “Arbeiterkultur im 19. Jahrhundert." Geschichte und Gesellschaft 5 (1979):

Kocka, Jürgen, ed. Bürgertum im 19. Jahrhundert. vol.1-3, Göttingen, 1995.

Kocka, Jürgen. "Klassen oder Kultur? Durchbrüche und Sackgassen in der Alltagsgeschichte." Merkur 36 (1986): 955-65.

Kocka, Jürgen, ed. Bürger und Bürgerlichkeit im 19. Jarhundert. Göttingen, 1987.

Kothes, Franz-Peter. Die theatraliche Revue in Berlin und Wien 1900-1938: Typen, Inhalte, Funktionen. Wilhelmshaven, 1977.

Kraus, Elisabeth. "Jüdische Stiftungstätigkeit: Das Beispiel der Familie Mosse in Berlin." Zeitschrift für Geschichtswissenschaft 45 (1997): 101-121.

Krause, G. Die Schönheit in der Zirkuskunst. Berlin, 1969.

Kühn, Volker. Spötterdämmerung: Vom langen Sterben des grossen kleinen Friedrich Hollaender. Frankfurt a. M., 1988.

Kühn, Volker. Das Kabarett der frühen Jahre. Ein freches Musenkind macht erste Schritte. Berlin, 1984.

Kusneszow, Jewgeni. Der Zirkus der Welt. Berlin, 1970.

Lange, Annemarie. Berlin zur Zeit Bebels und Bismarcks. Zwischen Reichsgründung und Jahrhundertwende. Berlin, 1984.

Langewiesche, Dieter. "Working-Class Culture and Working-Class Politics in the Weimar Republic." In Bernstein to Brandt, edited by Roger Fletcher. London, 1987.

Laqueur, Walter. Weimar Culture. New York, 1974.

Levine, Lawrence. High Brow/Low Brow: The Emergence of a Cultural Hierarchy in America. Cambridge, MA, 1988. 
Lidtke, Vernon L. The Alternative Culture: Socialist Labor in Imperial Germany. New York, 1986.

Liebeschütz, Hans. "Treitschke and Mommsen on Jewry and Judaism." In Year Book of the Leo Baeck Institute 7 (1962): 153-182.

Liedtke, Rainer. Jewish Welfare in Hamburg and Manchester, 1850-1914. Oxford, 1998.

Lifson, David S. "Yiddish Theatre." In Ethnic Theatre in the United States, edited by Maxine Schwartz Seller. Westport, CT, 1983.

Lifson, David S. The Yiddish Theater in America. Cranbury, 1965.

Lohalm, Uwe. Völkischer Radikalismus: Die Geschichte des Deutschvölkischen Schutz- und Trutzbundes 1919-1923. Hamburg, 1970.

Lynn, John A. The Bayonnets of the Republic: Motivation and Tactics in the Army of Revolutionary France, 1791-94. Urbana and Chicago, 1984.

Mason, Bim. Street Theatre and other Outdoor Performance. London, 1992.

Malhorta, Ruth. Manege frei: Artisten- und Circusplakate von Adolph Friedländer. Dortmund, 1979.

Markschiess-Van Trix, Julius and Bernhard Nowak. Artisten- und Zirkusplakate. Ein internationaler Überblick . Leipzig, 1975.

Maurer, Trude. Ostjuden in Deutschland, 1918-1933. Hamburg, 1986.

Mayne, Judith. Cinema and Spectatorship. London, 1993.

McAleer, Kevin. The Cult of Honor in Fin-de-Siècle Germany. Princeton, NJ, 1994.

Mc Luhan, Marshall. Understanding Media. New York, 1964.

Mendelsohn, Eszra. "On the Jewish Presence in Nineteenth-Century European Musical Life." Studies in Contemporary Jewry 9 (1993): 3-16.

Merdert, J., ed. Zirkus, Circus, Cirque. 28. Berliner Festwoche, Nationalgalerie Berlin, 1978.

Modleski, Tania, ed. Studies in Entertainment: Critical Approaches to Mass Culture. Bloomington, 1986.

Mommsen, Wolfgang. Bürgerliche Kultur und künstlerische Avantgarde: Kultur und Politik im deutschen Kaiserreich 1870-1918. Frankfurt a. M., 1994.

Morrow, John H. Jr. "Knights of the Sky. The Rise of Military Aviation." In Authority, Identity and the Social History of the Great War, edited by Frans Coetzee and Marilyn Shevin-Coetzee. Providence, 1995.

Mosse, George L. German Jews Beyond Judaism. Bloomington, 1985. 
Mosse, George L. Jüdische Intellektuelle in Deutschland. Frankfurt a. M., 1992.

Müller, Martin L. "Turnen und Sport im sozialen Wandel. Körperkultur in Frankfurt am Main während des. Kaiserreichs und der Weimarer Republik." Archiv für Sozialgeschichte 33 (1993):_107-136.

Neugebauer, Hans-Joachim. Judenfiguren: Drama und Theater im frïhen 19. Jahrhundert. Berlin, 1994.

Niewyk, L. The Jews in Weimar Germany. Barton Rouge, 1980.

Nipperdey, Thomas. Gesellschaft, Kultur, Theorie. Gesammelte Aufsätze zur neueren Geschichte. Göttingen, 1976.

Nissing, Herbert. Strassburger: Geschichte eines jüdischen Circus. Dormagen, 1993.

Nolan, Mary. "Imagining America, Modernizing Germany." In Dancing on the Volcano. Essays on the Culture of the Weimar Republic, edited by Thomas W. Kniesche and Stephen Brockmann, Camden House, 1996, pp.71-84.

Nolan, Mary. Visions of Modernity. American Business and Modernization of Germany. Oxford, 1994.

Opitz, Claudia. "Neue Weg der Sozialgeschichte? Ein kritischer Blick auf Otto Brunners Konzept des 'ganzen Hauses."' Geschichte und Gesellschaft 20 (1994): 88-98.

Penslar, Derek. "Philanthrophy, the 'Social Question' and Jewish Identity in Imperial Germany." Leo Baeck Institute Yearbook 38 (1993): 51-74.

Petro, Patrice. "Perception of Difference: Woman as Spectator and Spectacle." In Katharian von Ankum, ed. Women in the Metropolis. Gender and Modernity in Weimar Culture. Berkeley, CA, 1997.

Peukert, Detlev J. K. The Weimar Republic. The Crisis of Classical Modernity. New York, 1992.

Podehl, Enno. "Wandernde Puppenspieler und Bänkelsänger." In Fahrendes Volk. Spielleute, Schausteller, Artisten, exposition catalogue, May 2 to July 4, 1981, Städtische Kunsthalle Recklinghausen.

Pulzer, Peter. Jews and the German State. London, 1992.

Pulzer, Peter. The Rise of Political Anti-Semitism in Germany and Austria. Rev. ed. Cambridge, 1988.

Rahden, Till van. "Weder Milieu noch Konfession: Die situative Ethnizität der deutschen Juden im Kaiserreich in vergleichender Perspektive." In Religion und Milieu im deutschen Kaiserreich, edited by Olaf Blaschke and Frank-Michael Kuhlemann, Gütersloh, 1996.

Rahden, Till van. "Ideologie und Gewalt. Neuerscheinungen über den Antisemitismus in der deutschen Geschichte des 19. und 20. Jahrhunderts." In Neue Politische Literatur 41 (1996): 11-29. 
Reinke, Andreas. Judentum und Wohlfahrtspflege: Das jüdische Krankenhaus in Breslau 1744-1944. Hannover, 1998.

Reulecke, Jürgen. Geschichte der Urbanisierung in Deutschland. Frankfurt a. M., 1985.

Reynolds, Charles, and Regina Reynolds. Magic Posters: 100 Jahre Zauber-Plakate. Berlin, 1976.

Ribbe, Wolfgang, ed. Geschichte Berlins. Von der Märzrevolution bis zur Gegenwart, vol. 2. Munich, 1987.

Richard, Lionel. Cabaret, Cabarets, Origines et décadence. Paris, 1991.

Richter, Lukas. Der Berliner Gassenhauer, Darstellung, Dokumente, Sammlung. Leipzig, 1969.

Ritter, Gerhard, ed. Arbeiterkultur. Königstein, 1979.

Ritter, Gerhard A., and Klaus Tenfelde. Arbeiter im Deutschen Kaiserreich 1871-1914. Bonn, 1992.

Rogin, Michael. Blackface, White Noise: Jewish Immigrants in the Hollywood Melting Pot. Berkeley, CA, 1996.

Rothfels, Nigel T. "Bring 'em Back Alive: Carl Hagenbeck and Exotic Animal and People Trades in Germany, 1848-1914." Ph.D. Dissertation, Harvard University, 1994.

Rürup, Reinhard. Emanzipation und Antisemitismus. Studien zur "Judenfrage" der bürgrlichen Gesellschaft. Frankfurt a. M., 1975.

Rürup, Reinhard, ed. Jüdische Geschichte in Berlin. Berlin, 1995.

Sandrow, N. Vagabond Stars: A World History of Yiddish Theater. New York, 1986.

Saunders, Thomas J. Hollywood in Berlin: American Cinema and Weimar Germany. Berkeley, CA, 1994.

Schaaff, Martin. Die Buschens - 100 Jahre einer Circusdynastie. Berlin, 1984.

Schieder, Wolfgang, ed. Religion und Gesellschaft im 19. Jahrhundert. Stuttgart, 1994.

Schieder, Wolfgang, ed. Volksreligiosität in der modernen Sozialgeschichte. Göttingen, 1986.

Schleugl, Hans. Show Freaks und Monster. Köln, 1974.

Schneidereit, Otto. Berlin wie es weint und lacht: Spaziergänge durch Berlins Operettengeschichte. Berlin, 1973.

Schneidereit, Otto. Operettenbuch. Berlin, 1955.

Schneidereit, Otto. Paul Linke und die Entstehung der Berliner Operette. Berlin, 1981.

Schneidereit, Otto. Fritzi Massary. Versuch eines Portraits. Berlin, 1970. 
Schoeps, Julius, ed. Juden als Träger bürgerlicher Kultur in Deutschland. Stuttgart, 1989.

Scholz, R. "Ein unruhiges Jahrzehnt: Lebensmittelunruhen, Massenstreiks und Arbeitslosenkrawalle in Berlin 1914-1923." In Pöbelexzesse und Volkstumulte in Berlin. Zur Sozialgeschichte der Straße 1830-1980, edited by M. Gailus. Berlin, 1984.

Schütte Jürgen and Peter Sprendel, eds. Die Berliner Moderne, 1885-1914 Stuttgart, 1987.

Schulte, Regina. Sperrbezirke. Tugendhaftigkeit und Prostitution in der bürgerlichen Welt. Frankfurt a. M. 1979.

Schumann, Dirk. "Der aufgeschobene Bürgerkrieg: Sozialer Protest und Politische Gewalt in Deutschland." In Zeitschrift für Geschichtswissenschaft 44 (1996): 526-544.

Scott, Joan W. and Louise Tilly. "Woman's Work and the Family in Nineteenth-Century Europe." In Comparative Studies in Society and History 17 (1975): 36-64.

Sheehan, James J. German History 1770-1866. Oxford, 1989.

Showalter, Dennis Edwin. "Prussian Cavalry 1806-1871: The Search for Roles." Militärgeschichtliche Mitteilungen 19 (1976).

Sieder, Reinhard. Sozialgeschichte der Familie. Frankfurt a. M., 1987.

Simmel, Georg. On Individuality and Social Forms. Chicago, 1971.

Simon, Bettina. Jiddische Sprachgeschichte: Versuch einer neuen Grundlegung. Frankfurt a. M., 1988.

Smith, Helmut Walser. German Nationalism and Religious Conflict: Culture, Ideology, Politics, 1870-1914. Princeton, 1995.

Sorkin, David. The Transformation of German Jewry 1780-1840. New York, 1987.

Sorlin, Pierre. Mass Media: Key Ideas. London, 1994.

Sperr, Monika, ed. Schlager, Das große Schlagerbuch, Deutsche Schlager 1800-heute. Munich, 1978.

Sprengel, Peter. Populäres jüdisches Theater in Berlin von 1877 bis 1933. Berlin, 1997.

Stacy, Jackie. Star Gazing: Hollywood Cinema and Female Spectatorship. London, 1994.

Stark, Gary D. "All Quiet on the Home Front." In Authority, Identity and the Social History of the Great War, edited by Frans Coetzee and Marilyn Shevin-Coetzee. Providence, 1995.

Stern, Fritz. Gold And Iron: Bismarck, Bleichröder and the Building of the German Empire. New York, 1977.

Thods-Arora, Hilke. Für 50 Pfennig um die Welt. Die Hagenbeckschen Völkerschauen. Frankfurt a. M., 1989. 
Thompson, Alastair. "Honours Uneven: Decorations, the State and Bourgeois Society in Imperial Germany." Past and Present 144 (1994): 171-204.

Thompson, E. P. The Making of the English Working Class. New York, 1963.

Tilgner, Eva. Das Haus an der Spree: Von der Markthalle zum Friedrichstadtpalast. Berlin, 1974.

Ulrich, Walter. "Daten aus der Circuswelt." Manege: Eine Schriftenreihe für Circusfreunde vol. 4.

Ulrich, Walter. 100 Jahre Circuskunst in Berlin. Preetz, 1959.

Usborne, Cornelia. "The New Woman and Generational Conflict. Perceptions of Young Woman's Sexual Mores in the Weimar Republic." In Mark Roseman, ed. Generations in Conflict. Cambridge, MA, 1995.

Vogel, Jakob. Nationen im Gleichschritt: Der Kult der "Nation in Waffen" in Deutschland und Frankreich 1871-1914. Göttingen, 1997.

Volkov, Shulamit. "Die Erfindung einer Tradition. Zur Entstehung des modernen Judentums in Deutschland." Historische Zeitschrift 253 (1991): 603-28.

Volkov, Shulamit. Jüdisches Leben und Antisemitismus im 19. und 20. Jahrhundert. Munich, 1990.

Volkov, Shulamit. The Rise of Popular Antimodernism in Germany: Urban Artisan Masters, 1873-1896. Princeton, NJ, 1978.

Volkov, Shulamit. "The Ambivalence of Bildung." In The German-Jewish Dialogue Reconsidered: A Symposium in Honor of George L. Mosse. edited by Klaus L. Berghahn, 81-97, Franfurt a. M..

Volkov, Shulamit. "Erfolgreiche Assimilation oder Erfolg und Assimilation. Die deutschjüdische Familie im Kaiserreich." In Wissenschaftskolleg zu Berlin 1982/83. 374-387, Berlin, 1984.

Vondung, Klaus, ed. Kriegserlebnis: Der Erste Weltkrieg in der literarischen Gestaltung und symbolischen Deutung der Nationen. Göttingen, 1980.

Walser, Karin. Dienstmädchen. Frauenarbeit und Weiblichkeitsbilder um 1900. Frankfurt a. M., 1985.

Walter, Dirk. "Antisemitische Kriminalität und Gewalt in der Weimarer Republik." Ph.D. Dissertation, Universität Freiburg, 1997.

Weber, William. "Mass Culture and the Reshaping of Musical Taste." International Review of the Aesthetics and Sociology of Music 8 (1977): 5-21.

Weber, William. "The Muddle of the Middle Classes." Nineteenth-Century Music 3 (1979): $175-85$.

Weber, William. Music and the Middle Classes: The Social Structure of Concert Life in London, Paris and Vienna. New York, 1975. 
Weczerka, Hugo, ed., Schlesien: Handbuch der historischen Stätten. Stuttgart, 1977.

Wehler, Hans-Ulrich. Deutsche Gesellschaftsgeschichte vol. 3: Von der "Deutschen Doppelrevolution" bis zum Beginn des Ersten Weltkrieges 1849-1914. Munich, 1995.

Wertheimer, Jack. Unwelcome Strangers: East European Jews in Imperial Germany. Oxford, 1987.

Williams, Raymond. The Country and the City. London, 1973.

Winkler, Gisela, und Dietmar Winkler. Allez hopp durch die Welt: Aus dem Leben berühmter Akrobaten. Berlin, 1987.

Winkler, Dietmar. Zirkusgeschichte. Berlin, 1986.

Winokur, Mark. American Laughter: Immigrants, Ethnicity, and 1930s Hollywood Film Comedy. New York, 1996.

Wolff, Lutz. Puppchen, du bist mein Augenstern: Deutsche Schlager aus vier Jahrzehnten. Munich, 1981.

Zimmermann, Moshe. Die deutschen Juden 1914-1945. Munich, 1997. 